\title{
Integrated Solid Waste Management of Springfield, Massachusetts
}

National Renewable Energy Laboratory 1617 Cole Boulevard

Golden, CO 80401

NREL technical monitor: Philip Shepherd

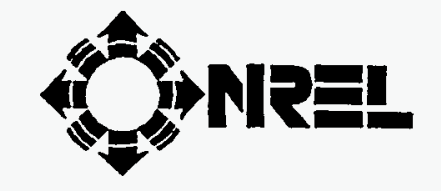

National Renewable Energy Laboratory 1617 Cole Boulevard

Golden, Colorado 80401-3393

A national laboratory of the U.S. Department of Energy Managed by the Midwest Research Institute for the U.S. Department of Energy

Under Contract No. DE-AC36-83CH10093

Prepared under Subcontract No. AAL-3-13185-01

November 1995 


\section{NOTICE}

This report was prepared as an account of work sponsored by an agency of the United States government. Neither the United States government nor any agency thereof, nor any of their employees, makes any warranty, express or implied, or assumes any legal liability or responsibility for the accuracy, completeness, or usefulness of any information, apparatus, product, or process disclosed, or represents that its use would not infringe privately owned rights. Reference herein to any specific commercial product, process, or service by trade name, trademark, manufacturer, or otherwise does not necessarily constitute or imply its endorsement, recommendation, or favoring by the United States govemment or any agency thereof. The views and opinions of authors expressed herein do not necessarily state or reflect those of the United States government or any agency thereof.

Available to DOE and DOE contractors from:

Office of Scientific and Technical Information (OSTI)

P.O. Box 62

Oak Ridge, TN 37831

Prices available by calling (615) $576-8401$

Available to the public from:

National Technical Information Senvice (NTIS)

U.S. Department of Commerce

5285 Port Royal Road

Springfield, VA 22161

(703) $487-4650$ 


\title{
Abstract
}

The subject document reports the results of an in-depth investigation of the fiscal year 1993 cost of the city of Springfield, Massachusetts, integrated municipal solid waste management (IMSWM) system, the energy consumed to operate the system, and the environmental performance requirements for each of the system's waste-processing and disposal facilities.

The document reports actual data from records kept by participants. Every effort was made to minimize the use of assumptions, and no attempt is made to interpret the data reported. Analytical approaches are documented so that interested analysts may perform manipulation or further analysis of the data. As such, the report is a reference document for Municipal Solid Waste management professionals who are interested in the actual costs and energy consumption, for a 1-year period, of an operating IMSWM system.

The report is organized into two main parts. The first part is the executive summary and case study portion of the report. The executive summary provides a basic description of the study area and selected economic and energy information. Within the case study are detailed descriptions of each component operating during the study period; the quantities of solid waste collected, processed, and marketed within the study boundaries; the cost of managing MSW in Springfield; an energy usage analysis; a review of federal, state, and local environmental requirement compliance; a reference section; and a glossary of terms.

The second part of the report focuses on a more detailed discourse on the above topics. In addition, the methodology used to determine the economic costs and energy consumption of the system components is found in the second portion of this report. The methodology created for this project will be helpful for those professionals who wish to break out the costs of their own integrated systems.

Other reports in the series include a synopsis of results and methodologies that presents the principal findings from the case studies and case studies of each of the six IMSWM systems evaluated in this program. In addition to Springfield, Massachusetts, the following systems participated in the evaluation: Minneapolis/Hennepin County, Minnesota; Palm Beach County, Florida; Scottsdale, Arizona; Seattle, Washington; and Sevierville, Tennessee.

\section{Key Words}

\author{
Case study \\ Composting \\ Cost analysis \\ Energy Analysis \\ Energy recovery \\ Environmental requirements: solid waste management \\ Integrated municipal solid waste management \\ Landfilling \\ Materials recovery \\ Municipal solid waste \\ Recycling \\ Resource recovery \\ Springfield, Massachusetts \\ Solid waste \\ SWANA \\ Waste-to-energy
}




\section{Foreword}

This case study report is one of six developed for the following integrated municipal solid waste management systems:

- Minneapolis (Hennepin County), Minnesota; NREL/TP430-20473

- Palm Beach County, Florida; NREL/TP430-8131

- $\quad$ Scottsdale, Arizona; NREL/TP430-7977

- Seattle, Washington; NREL/TP430-8129

- $\quad$ Sevierville, Tennessee; NREL/TP430-8136

- $\quad$ Springfield, Massachusetts; NREL/TP430-8137

All the reports, including a summary report (NREL/TP430-20471), are available through the National Renewable Energy Laboratory, 1617 Cole Boulevard, Golden, Colorado, 80401, or call (303)275-4363.

The authors are extremely grateful for the support and cooperation of the six systems managers and participants in those six systems. Without their assistance, this effort would not have been possible.

Funding for the conduct of the case studies and the development of the six reports was provided by the American Plastics Council and the United States Department of Energy's National Renewable Energy Laboratory.

In conducting the studies, the authors experienced considerable difficulty in gathering economic and energy information. In municipal solid waste management, no standard accounting methods exist. Further, local governments by tradition and practice maintain their financial records in a variety of ways to serve their own specific needs. The lack of a standard accounting procedure in the United States, and of standard definitions of solid waste, made the collection and analysis of the economic data a challenge. The methods for developing the cost information for this effort will be helpful to those with responsibilities for planning and implementing integrated municipal solid waste management systems. Also, the six sets of cost data will be useful for guiding other systems managers in their planning, cost accounting, and measuring of performance.

The development of the energy information represents a major step forward in analyzing integrated municipal solid waste management systems. The information in the six studies and the analytical methodology will be extremely useful to integrated municipal solid waste management systems planners, decision makers, and managers in the future.

Finally, as might be expected, the environmental regulatory information is limited. Although landfill and combustion facilities are under well-defined regulations, other portions of integrated municipal solid waste systems are not. The end result of these limitations is that the information presented on conformance with environmental requirements is sketchy for systems that do not include combustion.

A final caution to the readers of these reports is to not attempt to try to compare one system against the other. The authors deliberately did not do so for the very sound reason that it is ill-advised to attempt to compare systems that:

- are geographically different,

- are politically different,

- are structurally different in providing municipal solid waste services, 
- are at different stages of development, and

- face different regulatory requirements.

Rather, readers of these reports are encouraged to examine and analyze (using the techniques and analytical methods of the six studies) their own geographical, political, structure, stage of development, and regulatory status and then assess those findings against six other sets of data to see how they can best make the best decisions for their systems. 


\section{Acknowledgements}

SWANA is especially grateful for the assistance and support of many individuals and organizations who contributed information for this Springfield Case Study. From the city of Springfield: Philip Pike, director of public works; Dennis Akins, special projects director; Gary Herbert, comptroller; James Fitchet, senior comptroller; Michael Pattavina, special projects director; Jack Dowd, deputy director; Anthony Curdo, deputy director; and Michael Triggs, Vincent DeSantis, and George Ramano. From the Massachusetts Department of Environmental Protection-Greg Cooper, Steve Ellis, and Robin Ingenthron. From several private firms in the area: John Foley and Dana Martin-Hayden, Springfield Resource Recovery, Inc; Fred Marsh and John Schall, Resource Recovery Systems, Inc; William Connors, Clean Harbors; Paul Mahoney, United Waste Systems, Inc.; Quentin Hall; Ken Roskin, Mack Trucks; Edmond Bernier, Environmental Maintenance; and Ray Haluch. 


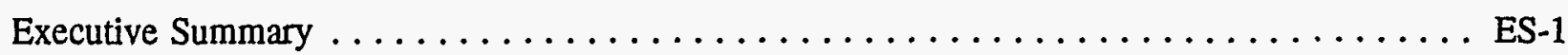

Introduction to Condensed Report $\ldots \ldots \ldots \ldots \ldots \ldots \ldots \ldots \ldots \ldots \ldots \ldots \ldots \ldots \ldots \ldots$

The City's Integrated Municipal Solid Waste Management System $\ldots \ldots \ldots \ldots \ldots \ldots \ldots \ldots$

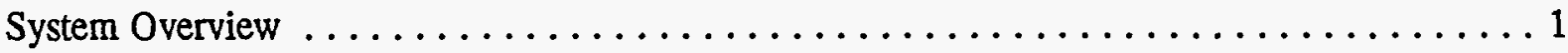

System Component Descriptions . . . . . . . . . . . . . . . . . . . . . . . . . . 4

Collection $\ldots \ldots \ldots \ldots \ldots \ldots \ldots \ldots \ldots \ldots \ldots \ldots \ldots \ldots \ldots, 4$

Materials Recovery Facility $\ldots \ldots \ldots \ldots \ldots \ldots \ldots \ldots \ldots \ldots \ldots \ldots \ldots \ldots, 7$

Waste-to-Energy Facility $\ldots \ldots \ldots \ldots \ldots \ldots \ldots \ldots \ldots \ldots \ldots \ldots$

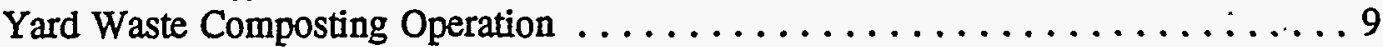

Office Paper Recycling Program $\ldots \ldots \ldots \ldots \ldots \ldots \ldots \ldots \ldots \ldots \ldots \ldots \ldots$

White Goods Preparation and Storage $\ldots \ldots \ldots \ldots \ldots \ldots \ldots \ldots \ldots \ldots \ldots \ldots$

Household Hazardous Waste Collection Day $\ldots \ldots \ldots \ldots \ldots \ldots \ldots \ldots \ldots \ldots \ldots$

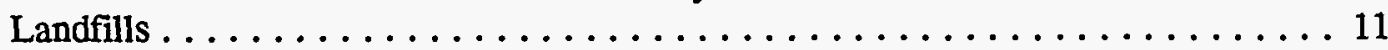

MSW Collected, Processed, and/or Disposed of by Springfield in FY $1993 \ldots \ldots \ldots \ldots$

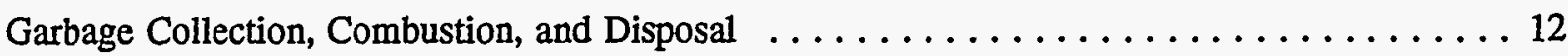

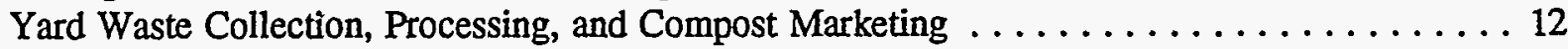

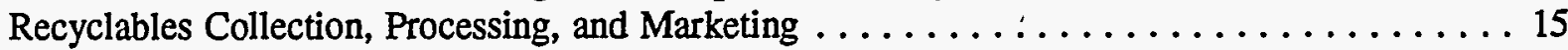

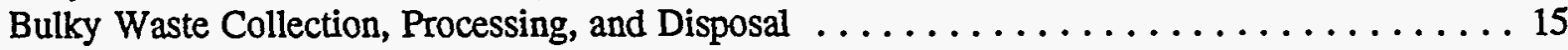

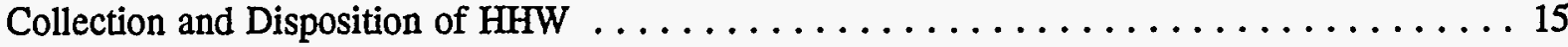

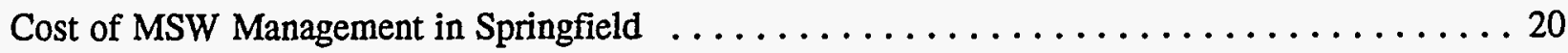

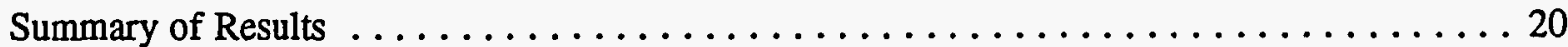

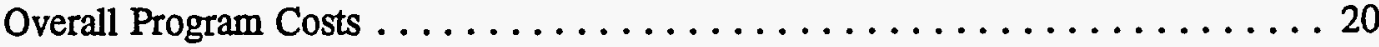

Program Incremental Costs . . . . . . . . . . . . . . . . . 20

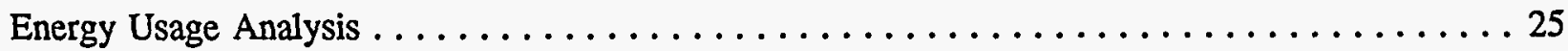

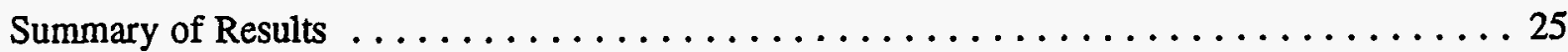

Environmental Regulations and Permit Requirements $\ldots \ldots \ldots \ldots \ldots \ldots \ldots \ldots$

Overview of Federal Environmental Legislation and Regulations $\ldots \ldots \ldots \ldots \ldots \ldots \ldots$

Overview of State and Local Environmental Regulations . . . . . . . . . . . . . 28

Permit Requirements for Each IMSWM System Facility . . . . . . . . . . 29

Waste-to-Energy Facility . . . . . . . . . . . . . . . . . 29

Materials Recovery Facility . . . . . . . . . . . . . . . . 29

Yard Waste Composting . . . . . . . . . . . . . . . . . 29

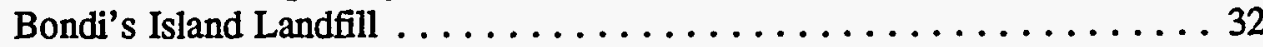


Appendix A: References

Appendix B: Glossary of Terms 


\section{List of Figures}

$\underline{\text { Page }}$

Figure 1. Map of the Commonwealth of Massachusetts $\ldots \ldots \ldots \ldots \ldots \ldots \ldots \ldots$

Figure 2. Counties of Massachusetts $\ldots \ldots \ldots \ldots \ldots \ldots \ldots \ldots \ldots \ldots \ldots \ldots \ldots$

Figure 3. Location of MSW management facilities in Springfield, Massachusetts $\ldots \ldots \ldots \ldots \ldots$

Figure 4. Site plan for Bondi's Island $\ldots \ldots \ldots \ldots \ldots \ldots \ldots \ldots \ldots \ldots \ldots \ldots \ldots \ldots \ldots \ldots$

Figure 5. MRF flow diagram - Springfield, Massachusetts $\ldots \ldots \ldots \ldots \ldots \ldots \ldots$

Figure 6 . Flow diagram of the waste-to-energy facility $\ldots \ldots \ldots \ldots \ldots \ldots \ldots$

Figure 7. MSW flow and resource recovery diagram - Springfield, MA (FY 1993) . . . . . . . 14

Figure 8. Materials recovered and revenues received in FY $1993 \ldots \ldots \ldots \ldots \ldots$

Figure 9. Allocation of total costs for IMSWM system in FY $1993 \ldots \ldots \ldots \ldots 2$

Figure 10. Allocation of Net Costs to Manage MSW by Springfield $\ldots \ldots \ldots \ldots \ldots \ldots$ 


\section{List of Tables}

$\underline{\text { Page }}$

Table 1. MSW Collected, Processed, and/or Disposed of by Springfield in FY $19933 \ldots \ldots$. . . 13

Table 2. Springfield MRF-Recovered Materials Sold in FY $1993 \ldots \ldots \ldots \ldots$

Table 3. Markets for Recovered Materials Sold in FY $1992 \ldots \ldots \ldots \ldots \ldots \ldots$

Table 4. Collection and Disposition of HHW in FY $1993 \ldots \ldots \ldots \ldots \ldots \ldots$

Table 5. Springfield FY 1993 Resource Recovery Program Incremental

Costs/Effectiveness ........................... 24

Table 6. Energy Consumption to Collect Garbage, Bulky Waste, Office Paper, and Recyclables in Springfield (FY 1993) . . . . . . . . . . . . . 26

Table 7. Implementation Schedule for Waste Disposal Bans $\ldots \ldots \ldots \ldots \ldots \ldots$

Table 8. Emissions Limits-Springfield $R R F$

Table 9. Wastewater Discharge Limitations-Springfield $\mathrm{RRF} \ldots \ldots \ldots \ldots \ldots \ldots$

Table 10. Permitting Activity-Springfield RRF $\ldots \ldots \ldots \ldots \ldots \ldots \ldots \ldots \ldots \ldots \ldots$ 


\section{Executive Summary}

\section{Introduction}

The following summary provides a short review of the key findings of the Springfield, Massachusetts case study. Readers are advised to read the condensed Springfield case study to fully understand how the economic, energy, and environmental results were developed. In addition, all data collected and analyzed during this study are available in the in-depth Springfield case study, with Appendices A through D.

Each integrated municipal solid waste management (IMSWM) system is unique due to geography, climate, customs, politics, and time. However, readers may benefit from the findings of this study and the study techniques and methodology to develop actual economic, energy, and environmental facts about their own IMSWM systems. Because each system is unique, readers are cautioned not to compare the findings of this particular study with other systems or studies.

\section{Background}

Springfield, Massachusetts (the "city"), is located in Hampden County in the Pioneer Valley of western Massachusetts. The city was incorporated in 1852. Springfield encompasses an area of approximately 33.1 square miles, yielding a population density of about 4740 persons per square mile. The 1993 population is estimated at 157,000 . There were approximately 61,000 housing units in the city in 1990, and about $94 \%$ were occupied.

During fiscal year (FY) 1993, about 61,200 tons of municipal solid waste were managed by the city's Department of Public Works (DPW).

\section{Overview of the Springfield IMSWM System}

The city's IMSWM system in FY 1993 consisted of the following components:

- Separate collection of garbage, recyclables, yard waste, and bulky wastes by the city

- A State-owned, privately operated regional materials recovery facility (MRF)

- A privately owned and operated regional waste-to-energy (WTE) facility

- A yard waste composting operation owned and operated by the city

- A city office paper recycling program

- A white goods preparation and storage area

- A city-sponsored annual household hazardous waste (HHW) collection day

- A city-owned, privately operated landfill for the disposal of ash and bypassed waste from the WTE facility, and some other types of wastes

- A privately owned and operated landfill for the disposal of bulky waste. 


\section{Collection}

The DPW collects garbage once a week, Tuesday through Friday, from all residents living in homes with four or fewer dwelling units. The number of dwelling units served in FY 1993 was about 44,500. The city also collects garbage from city office buildings and approximately 400 small commercial establishments, including some large multifamily homes. The city passed an ordinance in June 1986 making residential recycling mandatory for those households that are offered curbside collection by the city; the recyclables are collected every other week. Materials placed at the curb become the property of the city. Yard waste is collected if placed in either paper leaf bags or barrels, not in plastic bags. Since April 1991, residents have been asked to separate button batteries, which are collected with the recyclables.

\section{Processing Facilities}

The 360-ton-per-day (TPD) regional waste-to-energy (WTE) facility, located in Agawam, adjacent to Springfield's landfill and wastewater treatment complex, is owned by a subsidiary of the Fluor Corporation. Springfield is one of 10 communities in the Pioneer Valley that have a 25-year contract for the use of the WTE facility.

The state-owned, regional MRF is located in Springfield. It began operations in January 1990; it was operated in FY 1993 by Resource Recovery Systems, Inc. (RRS). The Commonwealth of Massachusetts pays all the capital, operation, and maintenance costs for the MRF. The city can deposit recyclables at no cost. The MRF has a capacity of 240 TPD.

The composting facility began operations in 1987. Originally it accepted leaves only, but in April 1993, other yard wastes were added.

\section{Landfills}

The Bondi's Island Sanitary Landfill, owned by the city, is located in the neighboring communities of Agawam and West Springfield. It is operated by Resource Control, Inc., under contract to the city. Bulky waste is not accepted at this landfill. In FY 1993, nonrecyclable bulky waste was disposed of at a privately owned and operated landfill located in the city of Chicopee.

\section{Definitions}

Municipal solid waste (MSW) is categorized in this case study as garbage, recyclables, yard wastes, bulky waste (including white goods), and HHW.

ANALYZED MSW - That portion of the total MSW stream for which the associated management net costs are known, or at a minimum, can be reasonably estimated. The reason for limiting the types of MSW included in Analyzed MSW is that only that portion of MSW should be included for which sufficient data were available to draw defensible conclusions regarding the allocation of cost to the tons of MSW managed. Consequently, the types of MSW included in Analyzed MSW will vary between IMSWM systems.

BULKY WASTE-Oversized items, including white goods and furniture, that have been separated from the MSW stream for separate collection. 
GARBAGE-Garbage is all MSW exclusive of source-separated trash, recyclables, yard waste, HHW, and bulky waste.

PROGRAM INCREMENTAL COSTS (OR SAVINGS)_-Determined for MSW management components (or programs) of each IMSWM system by calculating the system cost of MSW management, first with the inclusion of a specific program, and then calculating the cost of MSW management without that program. Landfilling is considered the basic program that is not optional. Therefore, the Program Incremental Cost is the difference between the cost of managing MSW with the inclusion of a particular program and the cost of managing MSW without that program.

RECYCLABLES-Materials that still have useful physical or chemical properties after serving their usefulness for a given individual or firm, and can, therefore, be reused or recycled for the same or other purposes.

YARD WASTE-Vegetative material that is segregated from the MSW stream for separate collection and/or processing, including grass, prunings, plants, and small tree limbs, but excluding tree stumps, landclearing debris, and other large vegetative matter.

\section{Key Findings}

\section{Discussion of Costs}

Of the approximately 61,200 tons of solid waste managed within the city, about 59,900 tons were analyzed ("analyzed MSW") to determine the cost of the city's IMSWM system. The cost to manage the remaining 1300 tons is excluded because collection costs are not known for certain self-hauled wastes, street-swept leaves, imported yard waste, and $H H W$.

\section{Overall Program Costs}

The total FY 1993 net cost to manage the approximately 59,900 tons of analyzed MSW was about $\$ 7.17$ million, or about $\$ 120$ per ton. This total net cost breaks down to the rounded numbers displayed in Table 1.

Table ES-1. Cost of Program Elements

\begin{tabular}{||l|c|c|c||}
\hline Category & Tonnage & Total Cost & Total Cost Per Ton \\
\hline Garbage & 44,700 & $\$ 5.6$ million & $\$ 125$ \\
Recyclables & 7,580 & $\$ 1.01$ million & $\$ 136$ \\
& & & \\
Yard Waste & 6,810 & $\$ 0.38$ million & $\$ 57$ \\
Bulky Waste & 807 & $\$ 0.16$ million & $\$ 197$ \\
Total/Average & 59,900 & $\$ 7.17$ million & $\$ 120$ \\
\hline
\end{tabular}

Collection costs account for $39 \%$ of the total cost of the Springfield system, while general and administrative expense is $16 \%$, landfill is $7 \%$, the MRF is $5 \%$, compost is $2 \%$, and other expenses are $1 \%$ of the total cost. 


\section{Program Incremental Costs}

The incremental cost for each of the resource recovery programs, i.e., the cost (or savings) associated with adding the resource recovery program to the IMSWM system, is the difference between the cost of managing all the MSW with the inclusion of a particular program and the cost of managing all the MSW without that program. The program incremental cost (or savings) is, therefore, a measure of the impact of any particular program on the cost of managing all MSW.

The FY 1993 Springfield system includes five programs that were intended to divert MSW from landfills. The program incremental cost (or savings) of each of the resource recovery programs in FY 1993 are included in Table 2.

Table ES-2. Incremental Cost of Program Elements

\begin{tabular}{||l|c|c|c||}
\hline \multirow{2}{*}{ Program } & Tonnage & \multicolumn{2}{|c|}{$\begin{array}{c}\text { Incremental Cost } \\
\text { (Savings) }\end{array}$} \\
\hline & & Dollars & \$ Per Ton \\
Waste-to-Energy & 45,677 & $\$ 322,500$ & $\$ 7$ \\
Yard Waste Composting & 7,515 & $\$ 274,000$ & $\$ 36$ \\
Office Paper Recycling & 22 & $\$ 1,500$ & $\$ 68$ \\
White Goods Recycling & 509 & $\$(41,300)$ & $\$(81)$ \\
MRF/Curbside Collection & 6,958 & $\$ 774,500$ & $\$ 111$ \\
\hline
\end{tabular}

In addition to the incremental cost or savings that can be attributed to each of the resource recovery programs, each of them contributes energy or materials or both to the economy and reduces the use of available landfill space. More complete descriptions of the methodologies to calculate the program incremental costs are given in the Appendices to the in-depth Springfield case study.

\section{Energy Usage Analysis}

The primary forms of energy used within Springfield's IMSWM system are transportation fuels for collection, haul to market, and facility vehicles; number 2 fuel oil; and electricity. Energy consumed in the use of recovered materials to make new products is excluded because it is beyond the IMSWM boundary. However, because many manufacturing processes that use recovered materials (e.g., aluminum recycling) use less energy than do virgin material processes, this exclusion may understate the overall energy efficiency of recycling.

Energy usage data were collected from the city and operators of the MRF and the RRFs. Some engineering estimates were made to supplement the data received. Data on energy consumption for the Springfield IMSWM system were analyzed, yielding estimates for the equivalent diesel gallons per ton shown in Table 3. 


\section{Environmental Regulatory Framework}

Environmental regulations for the elements of an IMSWM system are directed primarily at the facilities that serve such a system. For the most part, these facilities will be one or more of the following:

- Transfer station

- Materials recovery facility

- Compost facility

- Waste-to-energy facility

- Sanitary landfill.

In the Commonwealth of Massachusetts, the authority for regulating solid waste management and protecting against negative environmental consequences of such management activities is granted within the Solid Waste Act, which was enacted in 1987. The law is administered by the Department of Environmental Protection. The law indicates that "protection of public health, safety and the environment is primarily the prevention of pollution from the site, but also encompasses the operation of the facility within an integrated solid waste management system which maximizes material reuse and the conservation of energy." The regulations established under the law also require MSW landfills and waste-to-energy facility owners/operators to provide for recycling or composting of a minimum of $25 \%$ by weight of the average yearly amount of MSW the facility is approved to accept.

The city regulates solid waste practices pursuant to Solid Waste, Litter and Weeds of the City Ordinances (1986) and subsequent amendments.

Many federal environmental laws apply to the facilities operated in support of the Springfield IMSWM system, including the Clean Air Act, the Clean Water Act, the Safe Drinking Water Act, and the Resource Conservation and Recovery Act. Other regulatory agencies with permitting oversight of solid waste management facilities include: the Federal Aviation Administration, regarding stack height; the Federal Energy Regulatory Commission, regarding generation of electric power; and the U. S. Army Corps of Engineers, regarding wetlands.

All of the facilities operated in support of the Springfield IMSWM system in FY 1993 were in compliance with permit conditions.

Table ES-3. Energy Consumed to Collect Garbage, Bulky Waste, Office Paper, and Recyclables in Springfield (FY 1993)

\begin{tabular}{||l|c|c|c|c|c||}
\hline \multicolumn{1}{|c|}{ Garbage } & Garbage & $\begin{array}{c}\text { Bulky } \\
\text { Waste }\end{array}$ & $\begin{array}{c}\text { Yard } \\
\text { Waste }\end{array}$ & $\begin{array}{c}\text { Office } \\
\text { Paper }\end{array}$ & Recyclables \\
\hline Tons Collected & 44,707 & 1,316 & 6,814 & 22 & 7,048 \\
Diesel Fuel Consumed & 46,598 & 3,617 & 3,061 & 127 & 14,017 \\
(gallons) & & & & & \\
Millions of Btu & 6,820 & 530 & 450 & 20 & 2,050 \\
Gallons per Ton & 1.0 & 2.7 & 0.4 & 5.8 & 2.0 \\
\hline
\end{tabular}

Note: $\quad$ Conversion to millions of Btu assumes 146,390 Btu per gallon.

Source: $\quad$ City of Springfield-DPW, "Determination of Fiscal Year 1993 Total Costs for Various Solid Waste Programs," Computer Printout, August 20, 1993. 


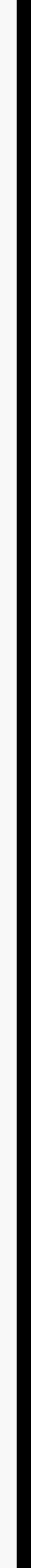




\section{Introduction to Condensed Report}

Springfield, Massachusetts ("the city"), is located in Hampden County in the Pioneer Valley of western Massachusetts, as shown in Figures 1 and 2. The city was incorporated in 1852. Springfield's population grew steadily from 1900 to the early 1960 s, peaking at about 175,000 people. It dropped to a recent low of about 152,000 in 1980 and is currently about 157,000 . There were 61,320 housing units in the city in 1990: 25,374 detached single units; 2637 attached single units; 17,663 two- to four-units; 5094 five- to nine-units; 8917 10- or more units; and 1635 mobile homes, trailers, and "other." About $94 \%$ of these housing units were occupied in 1990.

Springfield encompasses an area of approximately 33.1 square miles (including 1.38 square miles of water), yielding a population density of about 4740 persons per square mile. Springfield is 8.9 miles wide in an east-west direction and 6.4 miles long at its longest point in the north-south direction.

During fiscal year (FY) 1993, which extended from July 1, 1992, through June 30, 1993, about 61,200 tons of municipal solid waste (MSW) were managed by the city's Department of Public Works (DPW).

\section{The City's Integrated MSW Management System}

\section{System Overview}

The city's 1993 integrated municipal solid waste management (IMSWM) system consisted of the following system components:

- Separate collection of garbage, recyclables, yard waste, and bulky waste by the city

- A State-owned, privately operated regional materials recovery facility (MRF)

- A privately owned and operated regional waste-to-energy (WTE) facility

- A yard waste composting operation owned and operated by the city

- A city office paper recycling program

- A white goods preparation and storage area

- A city-sponsored annual household hazardous waste (HHW) collection day

- A city-owned, privately operated landfill for the disposal of ash and bypassed waste from the WTE facility, and some other types of wastes

- A privately owned and operated landfill for the disposal of bulky waste.

MSW is categorized in this report as comprising garbage, yard waste, recyclables, bulky waste (including white goods), and (HHW). 


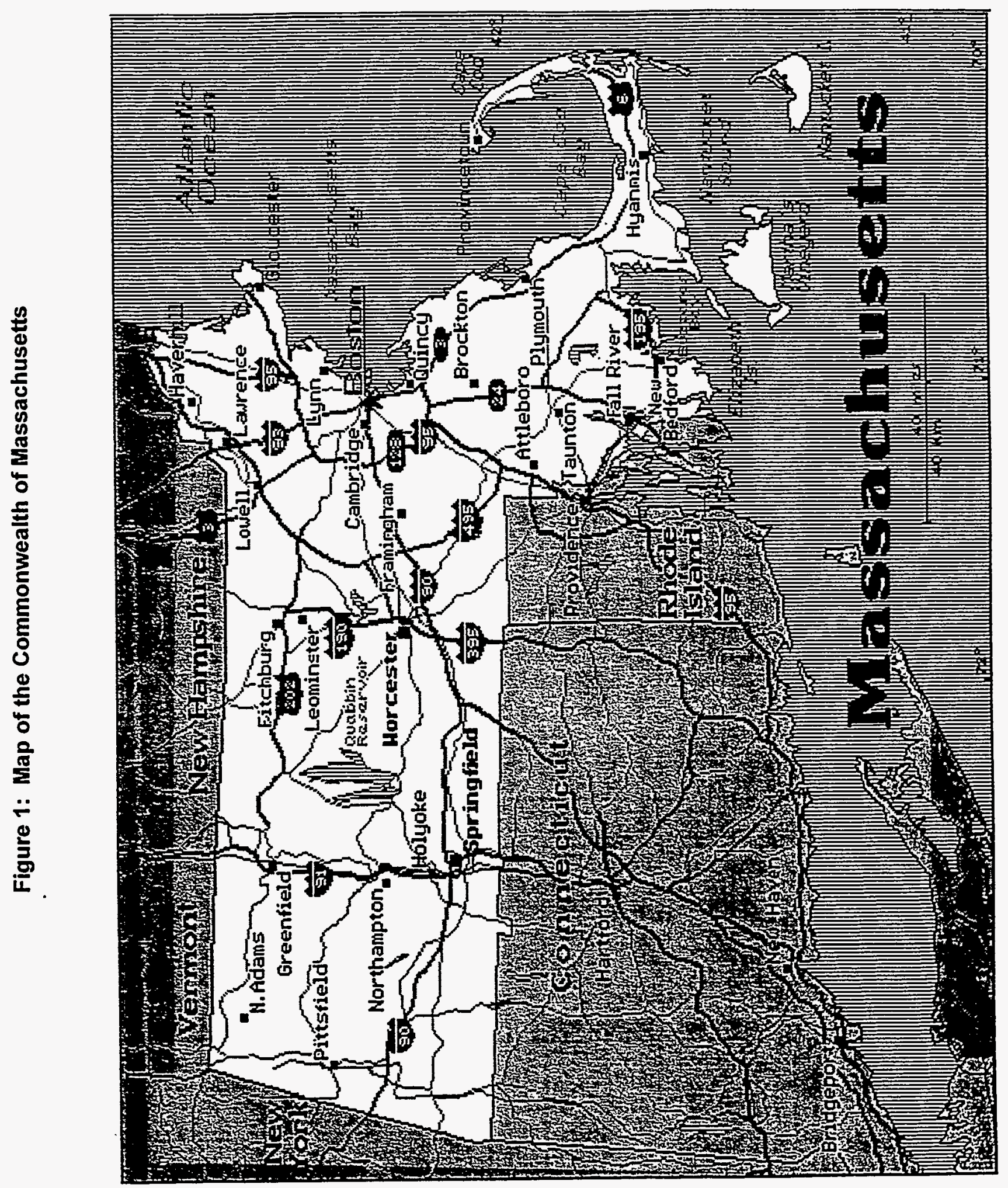




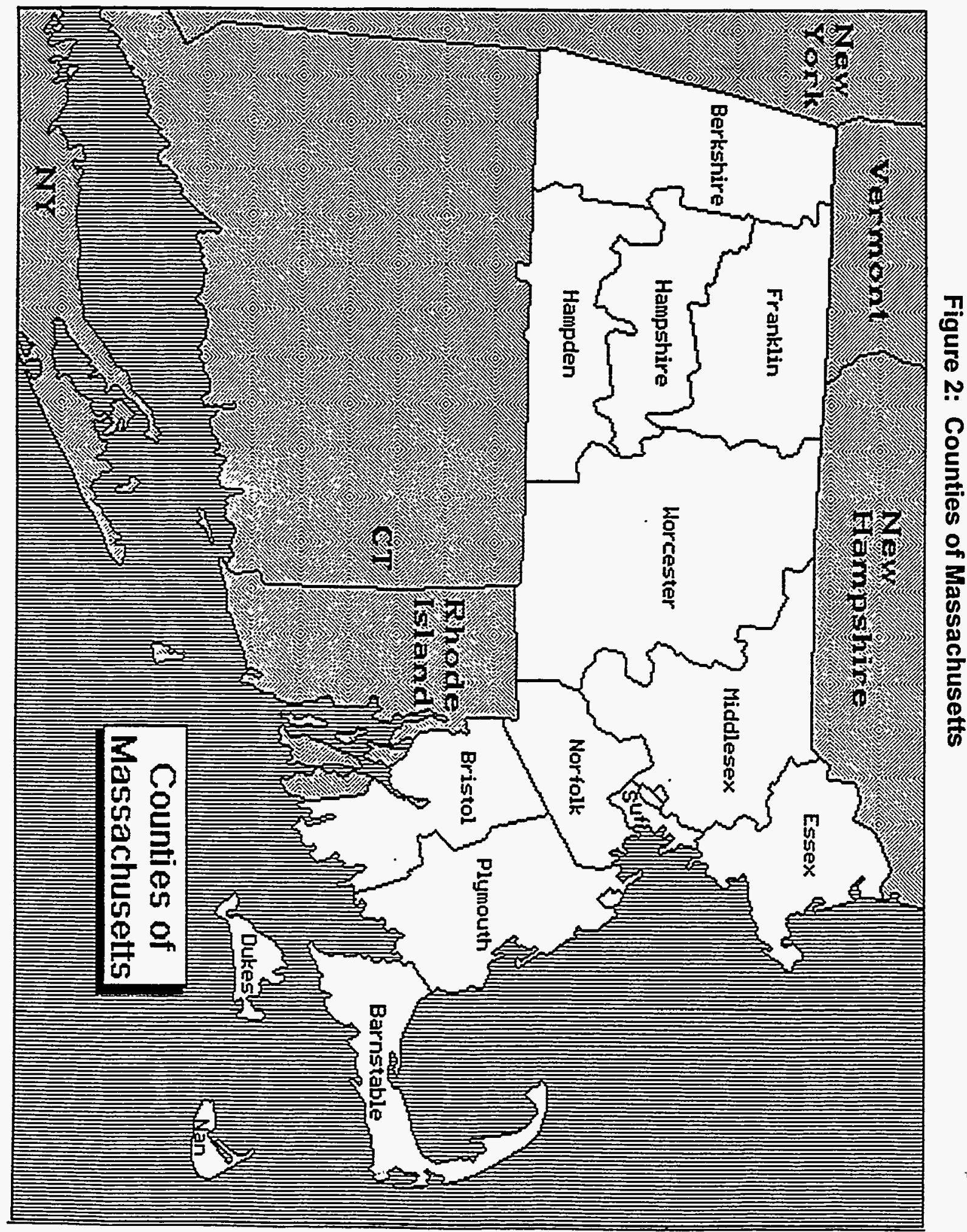




\section{System Component Descriptions}

Locations of the various IMSWM system facilities are shown in Figures 3 and 4.

\section{Collection}

The DPW collects garbage once a week, Tuesday through Friday, from all residents living in homes, including mobile homes, with four or fewer dwelling units. The number of dwelling units served in FY 1993 was about 44,500 . The city also collects garbage from city office buildings and approximately 400 small commercial establishments, including some large multifamily homes. In FY 1993, the city used a fleet of fourteen 31-cubic-yard rear-loading packer trucks for the collection of garbage (two were spare vehicles). Each truck is manned by a driver and two workers.

The city passed an ordinance in June 1986 making residential recycling mandatory for those households that are offered curbside collection by the city. In FY 1993, individuals living in homes with three or fewer dwelling units, exclusive of mobile homes, were offered curbside recycling services. Materials placed at the curb become the property of the city.

In FY 1993, approximately 41,000 households participated in the curbside recycling program. Recyclables are placed in 12-gallon "Blue Boxes" supplied by the city and are collected from each residence participating in the program once every other week on the same day that garbage is collected. In FY 1993, the city used a fleet of eight 31-cubic-yard collection vehicles. Each vehicle has two adjustable compartments, one for paper and the other for commingled containers. Each vehicle is manned by a single person.

In April 1991, the city, in conjunction with the other nine communities that use the WTE facility, began the curbside collection of button batteries used in such items as cameras, calculators, hearing aids, and watches. No other types or sizes of batteries are collected. Residents place their button batteries in an orange plastic bag provided by the city and then place that in their recycling Blue Box. The recycling truck operator takes the bag and leaves an empty one for future use. The batteries are dropped off at the MRF, where they are weighed and temporarily stored prior to being picked up by WTE facility personnel.

The city passed an ordinance in October 1988 making certain compostible leaves and yard waste separation mandatory. Prior to April 1993, individuals living in homes with four or fewer dwelling units, inclusive of mobile homes (i.e., the same households that receive garbage collection from the city), were offered, during the fall months, separate curbside collection of leaves. (Other yard waste was collected as garbage.) After April 1993, the city began separate collection of all types of yard waste. Materials placed at the curb become the property of the city.

Residents must place all yard waste in either paper leaf bags or barrels. Yard waste cannot be placed in plastic bags. The leaf bags "shall be a Sanitary Kraft Paper Sack or equal of 30-gallon capacity, two-ply fifty pound wet strength with decomposing glue and reinforced self-supporting square bottom closure." Special leaf collection days, on Mondays and Saturdays, were run from mid-October through midDecember 1992. From April 1993 through June 1993, the city collected yard waste once a week, Tuesday through Friday, from all residents who received garbage collection services. The yard waste was collected, on an overtime basis, in the 31-cubic-yard packer trucks used for garbage collection. Each truck has a three-person crew. A yard waste drop-off site is also maintained during the fall months at the city's landfill for residents of Springfield and Agawam. 
Figure 3: Location of MSW Management Facilities in Springfield, Massachusetts

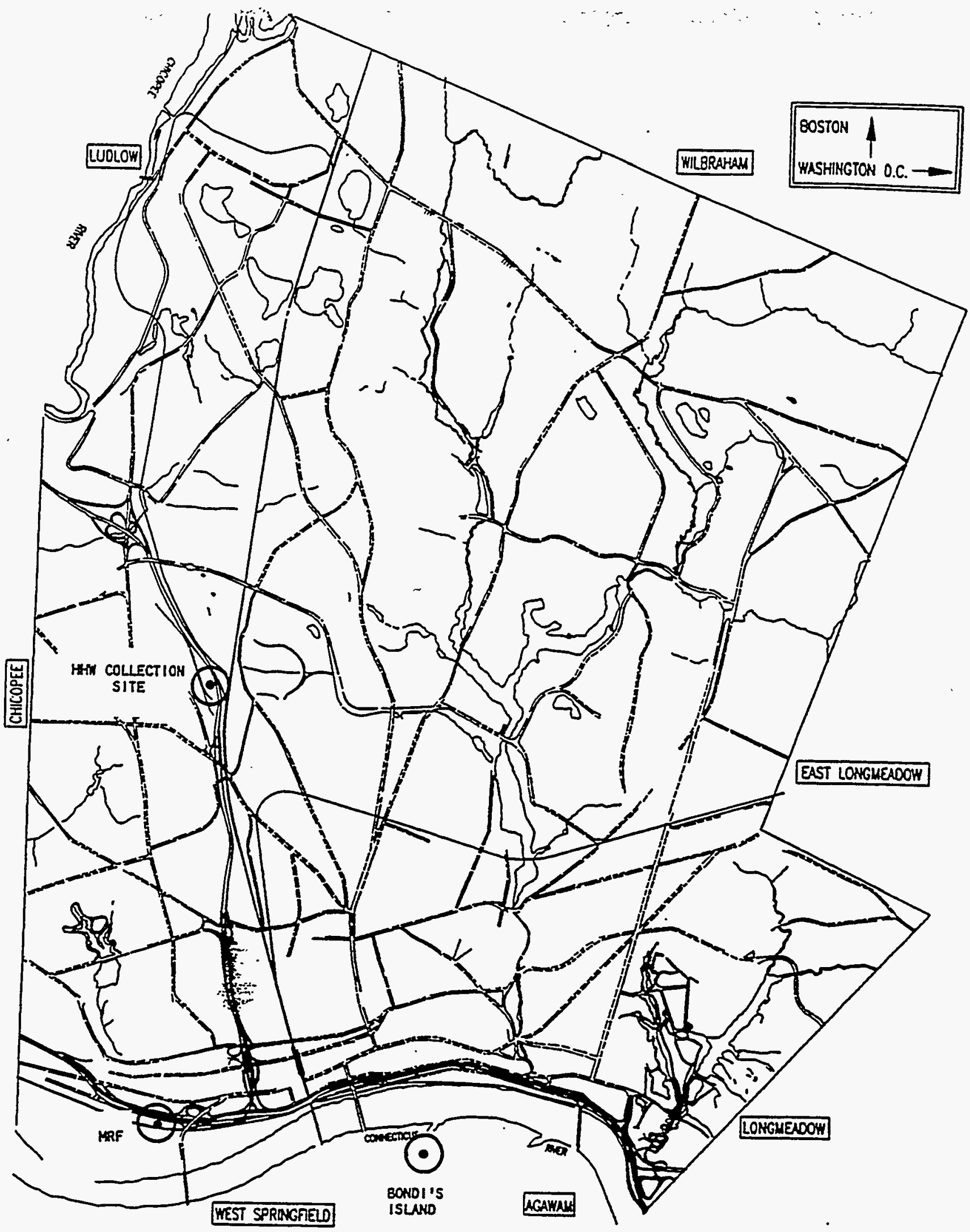




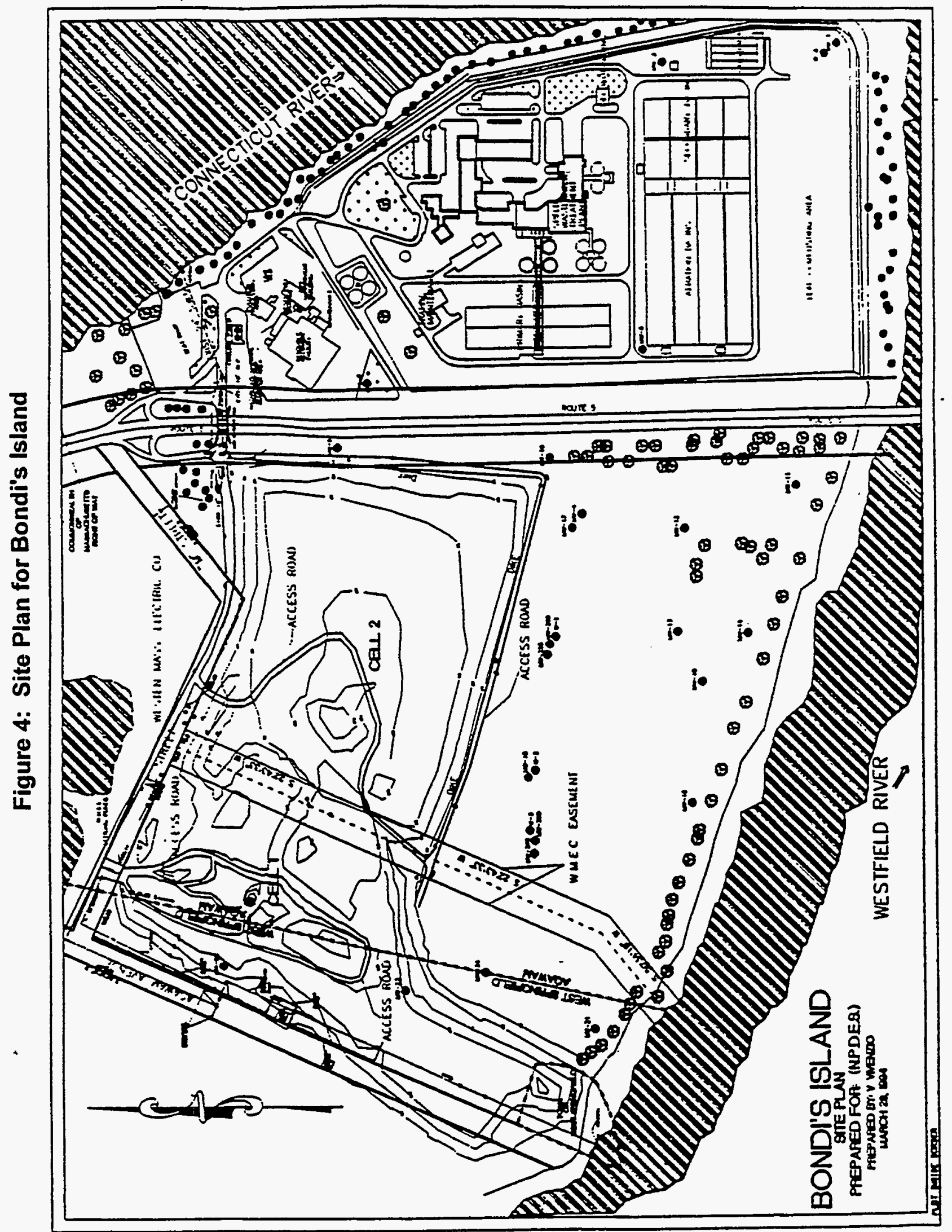


White goods and other bulky waste are collected on call by the city. The city used two bulk vehicles, each equipped with a hydraulic lift. Two-person crews are used to collect bulky wastes.

One of the litter collection vehicles is used once a week to pick up newspapers, magazines, catalogues, Kraft paper bags, white paper, colored paper, manila file folders, computer paper, phone books, and clasp envelopes from 10 city office buildings.

\section{Materials Recovery Facility}

The regional MRF is located in Springfield. Its building is owned by the Commonwealth of Massachusetts, acting through the Massachusetts Department of Environmental Protection (DEP), and the equipment used in the MRF is owned by the operator, Resource Recovery Systems, Inc. (RRS). The facility is being operated by RRS pursuant to a 5-year operating agreement with the Commonwealth.

The MRF began operations in January 1990 and services more than 90 communities in and around the Pioneer Valley. The Commonwealth pays all of the capital and operation and maintenance (O\&M) costs for the MRF. Thus, the users, including the city of Springfield, can deposit recyclables at no cost. Each community has a contract with the DEP which stipulates that the community will adopt and enforce a mandatory recycling program, collect and transport the recyclables to the MRF, and participate in the Commonwealth's promotional and public education programs.

The operator is obligated to process up to 240 tons of recyclables per day. Commingled containers (i.e., glass, ferrous metals, aluminum, PET, and HDPE) and mixed paper (e.g., newspaper, corrugated paper board, cartons, magazines, phone books) are processed in separate lines. Materials can be shipped from the facility by either truck or rail. A flow diagram of the MRF is provided in Figure 5.

When entering the site, each collection vehicle is weighed at the truck scale. After this initial weighing, the vehicle proceeds to the paper receiving area and unloads the paper. The truck returns to the scale to be reweighed and then proceeds to the bottle and can receiving area and dumps its remaining, commingled container load. In this way, an accurate account of the tonnage of paper and commingled containers delivered by each customer is obtained. Paper represents about $68 \%$, by weight, of the material delivered to the MRF.

The paper is handsorted into various grades of paper depending on the quality of the incoming loads and market demand for specific grades. In FY 1993, \#6 news, \#7 news, \#8 news, corrugated, carton, and a special mixed paper were recovered for sale. The paper is stored until it is baled.

The commingled containers deposited in the bottle and can receiving area (i.e., tipping floor) are first inspected by the front-end loader operator for large or unprocessible items or both. Acceptable material is pushed onto an inclined conveyor by a small front-end loader and is conveyed up to the elevated container sorting area. Ferrous metals are mechanically separated prior to the material reaching the handsorting area. The separated metals are flattened and deposited in storage bins. Aluminum, glass, and plastics are also handsorted. The color-sorted and mixed glass is then crushed, screened, and stockpiled in separate bins. Plastics are stored for later baling. Materials not handpicked are deposited in residue bins for disposal at a landfill. In FY 1993 the flint, green, amber, and mixed cullet; tin cans, scrap steel, aluminum cans, aluminum foil, and aluminum deposit; and PET deposit, clear HDPE, colored DPE, \#4 plastic, and other plastic were recovered for sale. 


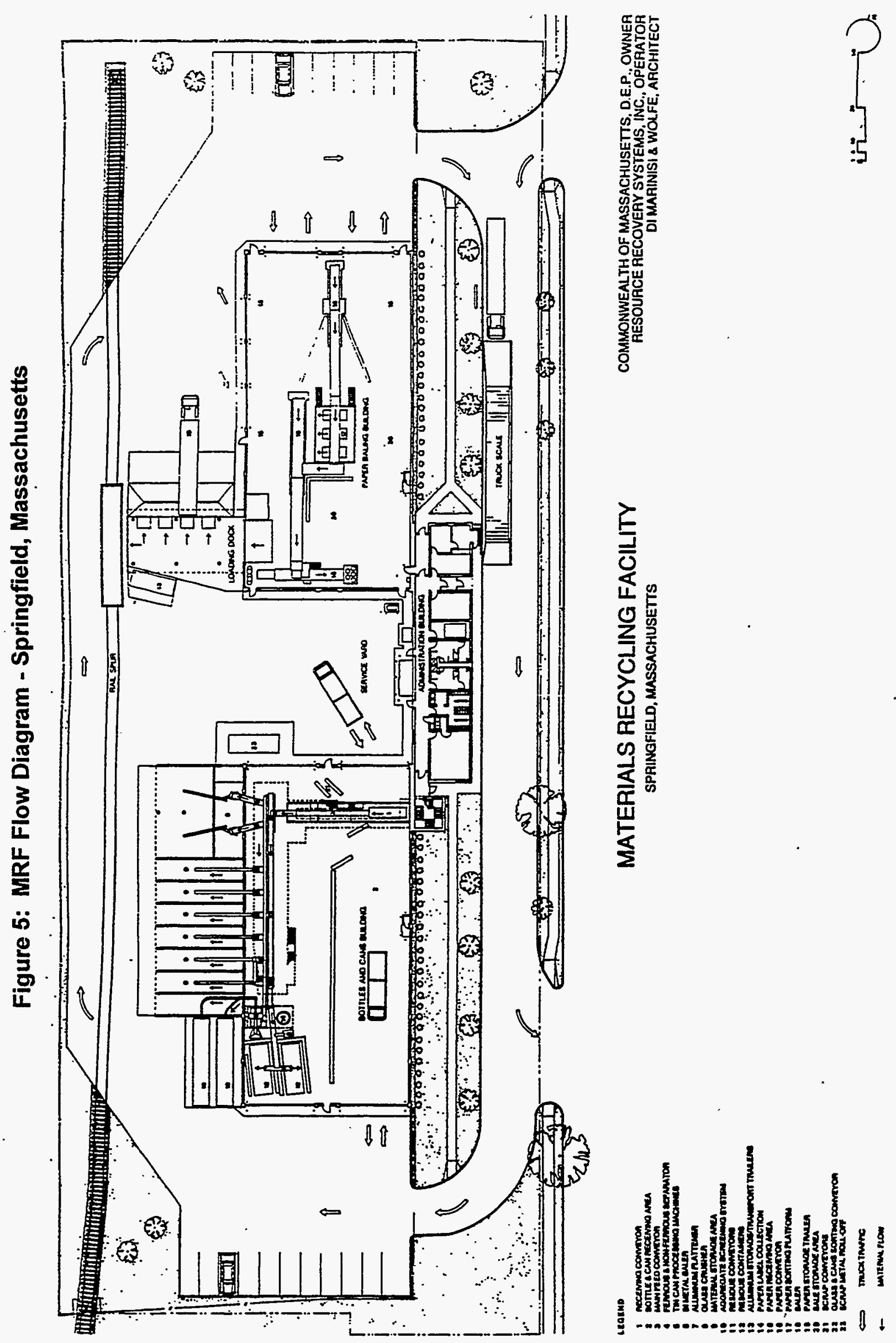




\section{Waste-to-Energy Facility}

The 360-ton-per-day (TPD) WTE facility, located in Agawam adjacent to Springfield's landfill and wastewater treatment complex (known as Bondi's Island), is owned by a subsidiary of the Fluor Corporation. The facility was developed by Vicon Recovery Systems and employs the Enercon technology for the combustion of MSW. Fluor Daniel designed and constructed the facility and was responsible for performance testing. Springfield Resource Recovery Inc., a subsidiary of Fluor Corporation, operates the facility.

Springfield is one of the 10 communities in the Pioneer Valley that have a 25-year contract for the use of the WTE facility. Commercial MSW is also accepted at the facility on a spot market basis. Full-scale commercial operation began in 1988.

The WTE facility generates both electricity and steam for sale. Electricity is sold to the Western Massachusetts Electric Company, and steam is sold to the Springfield Regional Wastewater Treatment Facility on Bondi's Island. Of the steam sold, about $17 \%$ was generated through the combustion of MSW; the balance was generated using an oil-fired package boiler.

After each delivery vehicle is weighed, the truck operator dumps its load either onto the tipping floor or into the storage pit. Unprocessible waste, such as bulky items, are set aside in roll-off containers for later disposal at a landfill. Some metals are also removed from the incoming MSW prior to combustion.

The three 120-TPD multiple-stepped, fixed-grate furnaces are fed by front-end loaders. Each combustion train is equipped with a dry lime injection system for the control of acid gases and a pulse-jet-cleaned baghouse for the control of particulate matter. The flue gases are then released to the atmosphere through a common 175-foot stack.

Bottom and fly ash are combined, quenched, and discharged by conveyor to the ash building for drying. Subsequently, the ash is delivered by truck to the city's Bondi's Island ash landfill for disposal. There is no postcombustion material recovery at the WTE facility.

Button batteries collected by the city are picked up by WTE personnel and sent to a reprocessor for recovery of mercury and other materials from the batteries. Another objective of the button battery program is to reduce the amount of mercury in the WTE facility flue gas and ash.

Figure 6 provides a flow diagram of the WTE facility.

\section{Yard Waste Composting Operation}

Since 1987, the city has operated an 8-acre site for composting its leaf and yard waste. The site is at the future expansion area of the Springfield Regional Wastewater Treatment Plant at Bondi's Island.

Prior to April 1993, leaves delivered from both Springfield and Agawam were unloaded into designated lines, or windrows. Because the leaves are placed in biodegradable paper bags or barrels, there is no need for any debagging operation. After April 1993, when other yard waste was included in the program, nonleaf yard waste, which then contained woody prunings and brush, was processed through a yard waste grinder. The grinder is mounted to a trailer, allowing the ground yard waste to be placed directly into windrows. 
Figure 6: Flow Diagram of the Waste-to-Energy Facility

SRR

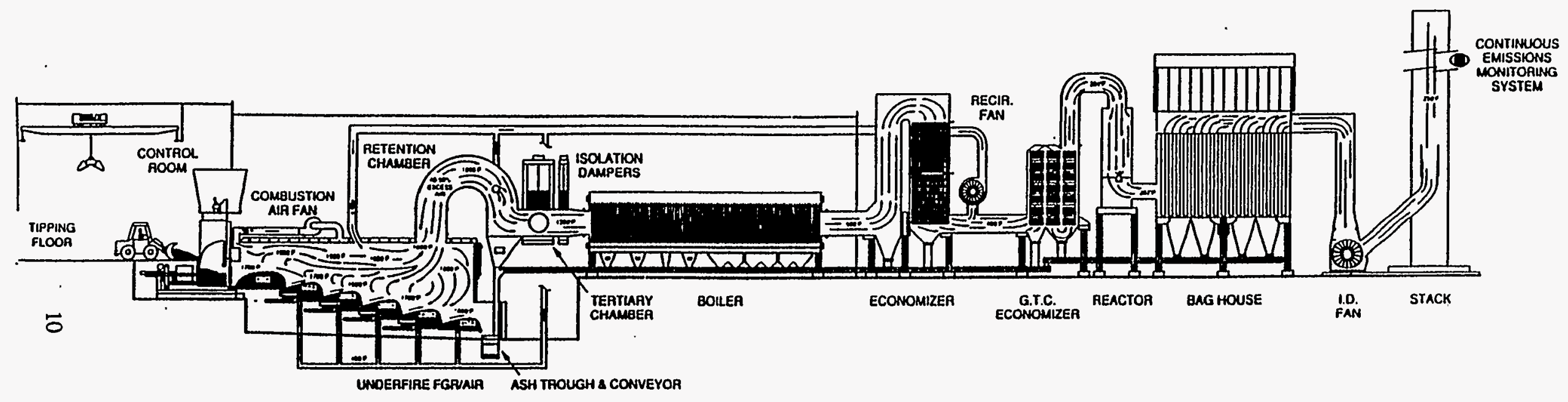

SPRINGFIELD RESOURCE RECOVERY, INC.

Agawam, Massachusetts 
Each windrow is initially about 275 feet long, 18 feet wide, and 8 feet high. Initially a windrow is turned about three times a week. As the compost material cures, the frequency of the turning time is reduced to less than once a week. It takes about 6 to 7 months to complete the composting process.

\section{Office Paper Recycling Program}

The city's office paper recycling program began in December 1990. The DPW distributed 12-gallon recycling Blue Boxes to each city department and 96-gallon wheeled recycling containers to each building. Clean, used office and computer papers are deposited in the Blue Boxes. The building custodians transfer the collected paper from the Blue Boxes to the 96-gallon containers. Every week the 96-gallon containers are wheeled to the curb for collection by the DPW. This office paper is delivered to the MRF for processing.

\section{White Goods Preparation and Storage}

The city collects white goods and other bulky metals from residents by appointment. The white goods are delivered to the city's landfill at Bondi's Island, where the chlorofluorocarbons are extracted from certain appliances for recycling. The white goods and metals are stored until at least 75 tons have accumulated. The city then notifies a contractor to pick up the material. The contractor brings a portable baler to the site, bales the white goods, and hauls the material away.

\section{Household Hazardous Waste Collection Day}

The city has been sponsoring HHW collection since 1988. In FY 1993, an HHW collection day was held. The site for the HHW program was donated by an industrial firm located in Springfield. The program was sponsored by the city, but carried out by 50 neighborhood, civic group, industrial, and municipal volunteers. The city hired The Green Paint Company to recycle both latex and solvent-based paints, and Clean Harbors of Natick, Inc., to manifest, haul, recycle, treat, incinerate, and/or dispose of in a hazardous waste landfill other HHW materials that were collected.

Residents were allowed to make appointments for dropping off their HHW. The city estimated that 500 households participated in the program.

During the HHW day, a swap table was set up where residents could trade usable products.

\section{Landfills}

The Bondi's Island Sanitary Landfill, owned by the city, is located in the neighboring communities of Agawam and West Springfield. Cells 1 and 2 contain 20 and 30 acres, respectively, and are located in Agawam. Cell 3, located in West Springfield, comprises 18 acres. Cell 2 is closed and covered and is being reserved for future vertical expansion as an ash monofill, and cell 3 is closed with no plans for its future expansion. Only cell 1 is currently active.

Cell 1 is divided into 10 subcells. The subcells have either a double liner system, consisting of a primary, 60-mil, high-density, polyethylene or a 30-mil, polyvinylchloride liner installed over a 2-to 4-foot thick, low permeability, clay secondary liner. One foot of sand was placed over the liner for protection and to facilitate leachate collection. 
A leachate collection and pretreatment facility collects and pretreats contaminated groundwater resulting from the original unlined landfill. Final treatment of the leachate is performed at the wastewater treatment facility. The landfill also has a landfill gas control system.

The landfill is operated by Resource Control, Inc. (RCI) under contract to the city. RCI is responsible for the proper disposal of ash and bypassed MSW from the WTE facility, sludge compost from the city's sewer sludge composting facility, grit and screening from the wastewater treatment facility, catch basin and sewer cleanings, and street sweepings delivered to the landfill for disposal. Separate subcells are used for the disposal of ash and the other wastes disposed of in Cell 1.

To conserve space, bulky wastes are not accepted at the Bondi's Island landfill. In FY 1993, nonrecyclable bulky wastes were disposed of at a privately owned and operated landfill, located in the city of Chicopee.

\section{MSW Collected, Processed, and/or Disposed of By Springfield in FY 1993}

A total of approximately 61,200 tons of MSW was collected, processed, or disposed of by the city in FY 1993. Of this amount, $73.0 \%$ was garbage, $13.0 \%$ was yard waste, $11.6 \%$ was recyclables, $2.2 \%$ was bulky waste (including white goods), and less than $0.1 \%$ was HHW. Table 1 summarizes the tonnage collected, processed, and/or disposed of by the city during FY 1993. This tonnage does not include MSW collected by private firms from residential buildings with five or more dwelling units or from commercial, institutional, or business establishments. An MSW flow and resource recovery diagram of this waste stream is depicted in Figure 7.

\section{Garbage Collection, Combustion, and Disposal}

A total of 44,707 tons of garbage was collected by the city from residences with four or fewer dwelling units (including mobile homes), litter barrels located throughout the city, city office buildings, and approximately 400 small commercial establishments. All of this tonnage was delivered to the WTE facility, accounting for about $39 \%$ of the total MSW received there.

Data on the quantity of garbage collected within the city by private firms from multifamily residential (i.e., five or more dwelling units) or commercial, institutional, and business establishments is not available.

About 23 tons of metals were recovered from city garbage at the WTE facility (prior to combustion) for recycling. The WTE facility generated about 14,810 tons of ash from the city-delivered garbage.

\section{Yard Waste Collection, Processing, and Compost Marketing}

The city collected 6814 tons of yard waste in FY 1993 from its residents. Of this amount, 3878 tons (or 57\%) were leaves, and the remaining 2936 tons were other yard wastes, such as grass, garden waste, weeds, pruning, and brush. All of this tonnage was delivered to the city's yard waste composting site. In addition, 364 tons of leaves were delivered by Springfield residents to the city's landfill for transfer to the composting site, and 337 tons of leaves were swept from city streets. Pursuant to an Intermunicipal Agreement between Springfield and the city of Agawam, an additional 607 tons of leaves were accepted and processed from its residents. In total, 8122 tons of yard waste were processed by the city in FY 1993: 5186 tons of leaves and 2936 tons of other yard wastes. 
Table 1. MSW Collected, Processed, and/or

Disposed of by Springfield in FY 1993 (a)

\begin{tabular}{||l|r|r||}
\hline \multicolumn{1}{|c|}{ Waste Type } & Percent & Tons \\
\hline Garbage & 73.0 & 44,707 \\
City Collected to WTE & & \\
Yard Waste & 11.1 & 6,814 \\
City Collected to Compost Site & 0.6 & 337 \\
Street Sweeper & 0.6 & 364 \\
· & $\underline{1.0}$ & $\frac{607}{122}$ \\
Self Haul to Compost Site & 13.3 & \\
Agawam & & 7,048 \\
Subtotal Yard Waste & 11.5 & 0 \\
Recyclables & 0.0 & $\frac{22}{7,070}$ \\
City Collected to MRF & $\underline{0.0}$ & \\
Button Batteries (b) & 11.6 & 509 \\
Office Paper & & $\underline{807}$ \\
Subtotal Recyclables & 0.8 & 1,316 \\
Bulky Waste & $\underline{1.3}$ & $\underline{15}$ \\
White Goods & 2.2 & 61,230 \\
Others & $\underline{0.0}$ & \\
Subtotal Bulky Waste & 100.0 & \\
Household Hazardous Waste & & \\
Totals & & \\
\hline \hline
\end{tabular}

SOURCE: DPW, Solid Waste Management Plan, March 1994.

Notes: (a) This table provides data on wastes that are managed by the city of Springfield. As such, this table does not include the waste generated or recycled by commercial, institutional, and business establishments. Therefore, the data in this table do not provide a complete account of waste generation and recycling activities in Springfield.

(b) Springfield Resource Recovery, Inc., indicated that 1282.7 grams (about 2.8 pounds) of button batteries were collected in FY 1993 from all the communities using the waste-to-energy facility. 
Figure 7: MSW Flow and Resource Recovery Diagram - Springfield, MA (FY 1993)

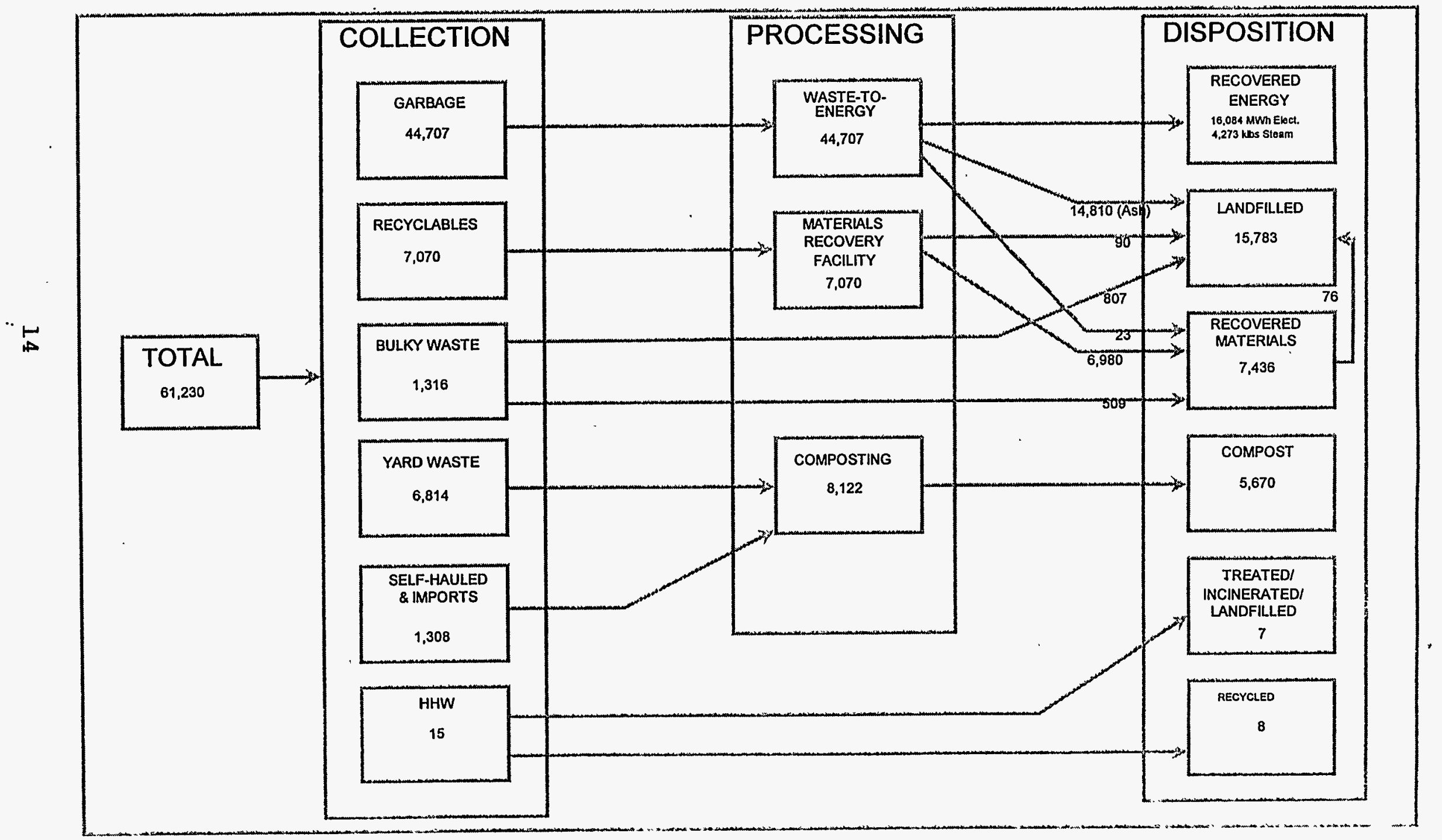


From this yard waste, the city produced about 5670 tons of compost. About $10 \%$ was given away for use by residents, $35 \%$ was used for municipal projects, and the balance was put out for bid. The compost put out for bid was purchased by Ray Haluch, Inc., for $\$ 1.21$ per ton. This compost was mixed with top soil and sold as blended top soil.

\section{Recyclables Collection, Processing, and Marketing}

The city collected approximately 7070 tons of recyclables from two different programs: the curbside collection program, which included the collection of button batteries, and the office paper recycling program.

In FY 1993, the city collected 7048 tons of recyclables from residents living in households with three or fewer dwelling units, excluding mobile homes. Of this amount, 5057 tons (or 72\%) were paper and 1991 tons (or 28\%) were commingled containers. All of these recyclables were delivered to the MRF for processing. The city also collected 22 tons of office paper from city buildings. This paper was delivered to the MRF for processing.

The MRF accepts recyclables collected from residents living in more than 90 communities in the Pioneer Valley. In total, about 44,100 tons of recyclables were delivered to the MRF in FY 1993; thus, the city accounted for about $16 \%$ of the materials delivered to the MRF. About 42,500 tons of recovered materials were sold, 560 tons were disposed of as residue, and 1040 tons were inventoried. Table 2 shows the types and quantities of materials sold in FY 1993, and Figure 8 compares the percentage, by weight, of the materials sold to the percentage of revenues received from each type of material. Although aluminum accounted for about $0.3 \%$ of the materials sold, it contributed almost $14 \%$ of the revenues received.

The materials recovered were sold to numerous remanufactures, as shown in Table 3. As can be seen from this table, the majority of the material sold was shipped by transfer trailers. The remanufactures were located throughout the Northeast at distances ranging from 55 to 1300 miles (one way) from Springfield.

\section{Bulky Waste Collection, Processing, and Disposal}

The city collected about 1316 tons of bulky waste in FY 1993. About 807 tons, or $61.3 \%$, of the bulky waste was disposed of at a private landfill operated by the Connecticut Valley Disposal Company. The remaining 509 tons, or $38.7 \%$, were white goods and other recyclable metals. This material was sold to Environmental Maintenance Metal Processors of Waterbury, Connecticut, for $\$ 14$ per ton. The white goods are processed to recover ferrous and nonferrous metals and plastics. About $15 \%$, by weight, or 76 tons, is disposed of as residue. The recovered materials are shipped between 110 and 1200 miles, depending on market conditions, for remanufacturing.

\section{Collection and Disposition of HHW}

An estimated 15 tons of material was delivered on the HHW collection day. The types and amounts of materials collected are provided in Table 4. About 38\% of the material was flammable liquids, such as asphalt sealers, that could not be consolidated because of its viscosity or because it was solidified. About $20 \%$ of the HHW collected was paint-related material, and another $16 \%$ was consolidated oil. In total, these three classes of materials represent almost $74 \%$, by weight, of the HHW collected.

Of the material collected, more than $50 \%$ was recycled. Of this amount, about $44 \%$ (i.e., consolidated liquid such as mineral spirits, thinners, solvents, and antifreeze, consolidated oil, and consolidated paints) 
Table 2: Springfield MRF- Recovered Material Sold, FY 1993

\begin{tabular}{|c|c|c|c|}
\hline $\begin{array}{l}\text { Recovered Material } \\
\text { Components }\end{array}$ & $\begin{array}{l}\text { Annual } \\
\text { Tonnage } \\
\text { Sold }\end{array}$ & $\begin{array}{c}\text { Percent of } \\
\text { Total } \\
\text { Component } \\
\text { Sold } \\
\end{array}$ & $\begin{array}{l}\text { Percent of } \\
\text { Total } \\
\text { Materials } \\
\text { Sold } \\
\end{array}$ \\
\hline \multicolumn{4}{|l|}{ GLASS } \\
\hline Flint & 3,699 & 37.9 & 8.7 \\
\hline Green & 837 & 8.6 & 2.0 \\
\hline Amber & 470 & 4.8 & 1.1 \\
\hline Aggregate Cullet & 4,754 & 48.7 & 11.2 \\
\hline Subtotal & 9,760 & 100.0 & 23.0 \\
\hline \multicolumn{4}{|l|}{ METALS } \\
\hline Tin Cans & 3,432 & 95.0 & 8.1 \\
\hline Steel Scrap & 33 & 0.9 & 0.1 \\
\hline Other Metals & 0 & 0.0 & 0.0 \\
\hline Aluminum Cans & 107 & 3.0 & 0.3 \\
\hline Aluminum Deposit \& Scrap & 7 & 0.2 & 0.0 \\
\hline Aluminum Foil & 34 & 0.9 & 0.1 \\
\hline Subtotal & 3,612 & 100.0 & 8.5 \\
\hline \multicolumn{4}{|l|}{ PLASTICS } \\
\hline PET & 53 & 14.6 & 0.1 \\
\hline \#4 Plastic & 13 & 3.6 & 0.0 \\
\hline PET Deposit & 6 & 1.6 & 0.0 \\
\hline Other Plastic & 0 & 0.0 & 0.0 \\
\hline Colored HDPE & 97 & 26.5 & 0.2 \\
\hline Clear HDPE & 196 & 53.8 & 0.5 \\
\hline Subtotal & 365 & 100.0 & 0.9 \\
\hline \multicolumn{4}{|l|}{ PAPER } \\
\hline Special Mixed Paper & 659 & 2.3 & 1.5 \\
\hline \#6 News & 13,297 & 46.2 & 31.3 \\
\hline \#7 News & 5,956 & 20.7 & 14.0 \\
\hline \#8 News & 6,143 & 21.3 & 14.5 \\
\hline Corrugated & 2,636 & 9.2 & 6.2 \\
\hline Cartons & 84 & 0.3 & 0.2 \\
\hline Subtotal & 28,775 & 100.0 & 67.7 \\
\hline TOTAL MATERIALS SOLD & 42,512 & & 100.00 \\
\hline
\end{tabular}

Sources:

1. DEP, "Monthly Revenue, Springfield Material Recycling Facility," December 1992, by Charles Leto, Department of Solid Waste Management.

2. DEP, "Monthly Revenue \& Fiscal Year 94, Springfield Material Recycling Facility," January 27, 1993, by Greg Cooper, Department of Solid Waste Management. 
Figure 8: Materials Recovered and Revenues Received in FY 1993

Springfield Materials Recovery Facility

Tons Sold

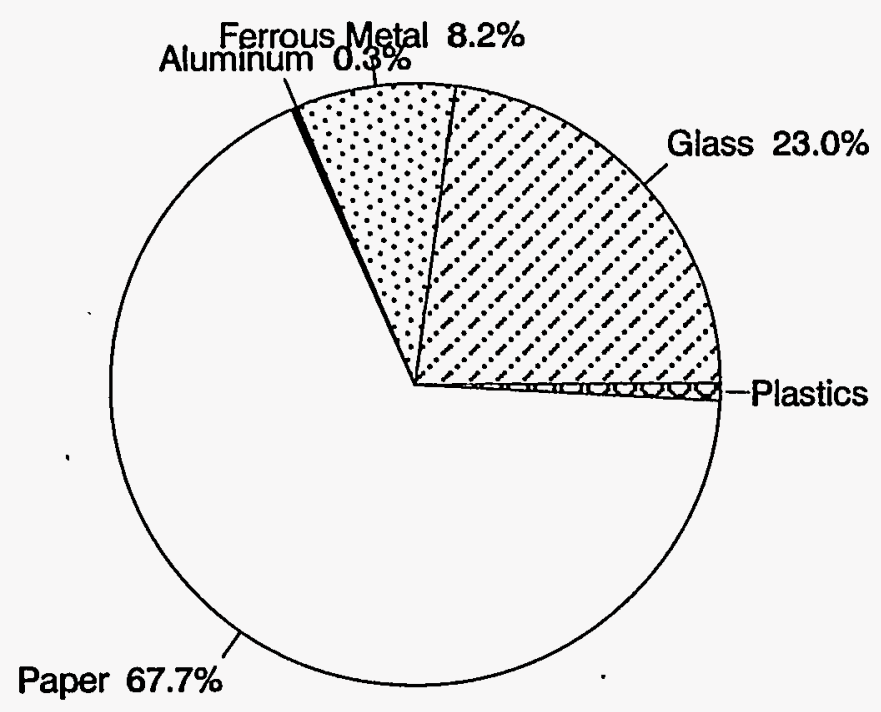

Net Revenues

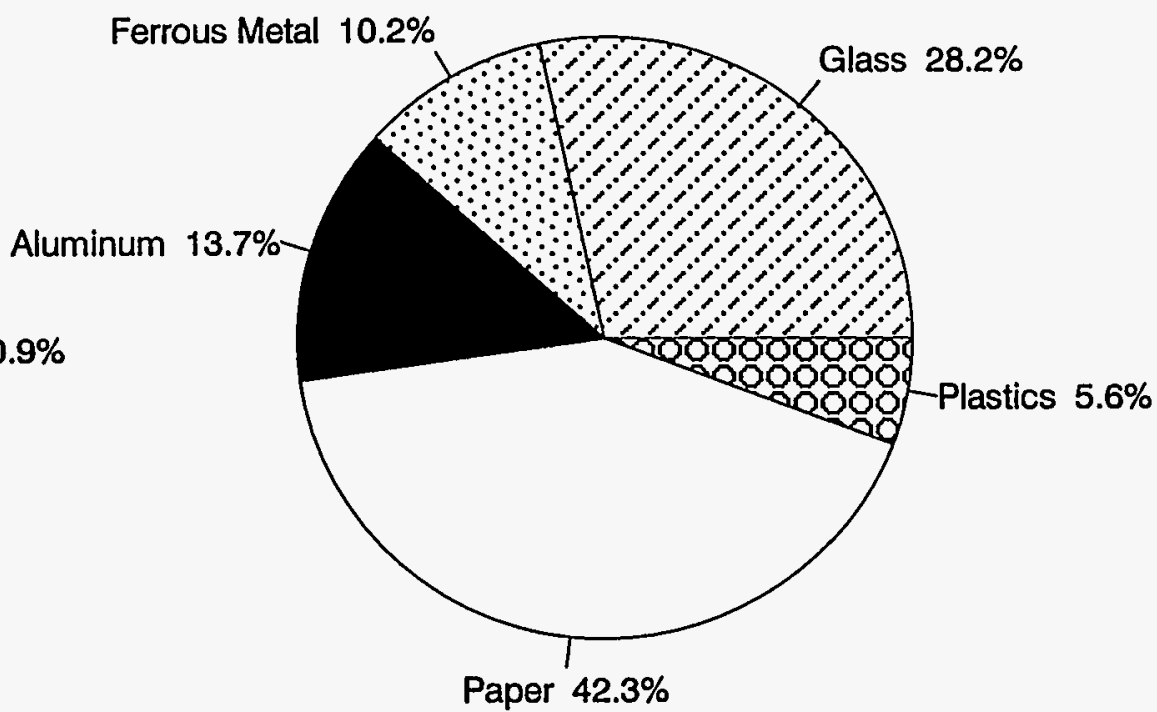


Table 3: Markets for Recovered Materials Sold in FY 1992

\begin{tabular}{|c|c|c|c|c|c|c|}
\hline \multicolumn{2}{|c|}{$\begin{array}{l}\text { Recovered Materials } \\
\text { (Tons) }\end{array}$} & \multirow[t]{2}{*}{$\begin{array}{l}\text { Vendor } \\
\text { (Location) }\end{array}$} & \multirow[t]{2}{*}{\begin{tabular}{|c|} 
Distance to \\
Vendor \\
(Miles) \\
\end{tabular}} & \multirow[t]{2}{*}{ Mode of Transport } & \multirow[t]{2}{*}{$\begin{array}{l}\text { Remanufacture } \\
\text { Reuse }\end{array}$} & \multirow[t]{2}{*}{ Comments } \\
\hline Glass & & & & & & \\
\hline Flint & 3,699 & Foster Forbes (Milford, CT) & 70 & Transfer Trucks & Cullet; New Bottles & Other Markets: Elmira, NY; Wineland, NJ; \\
\hline Green & 837 & & & & & Connellsville, PA \\
\hline Amber & 470 & & & & & \\
\hline Aggregate & 4,754 & CT - DOT (Enfield, CT) & 70 & Transfer Trucks & Roadway Aggregate & \\
\hline \multicolumn{7}{|l|}{ Metals } \\
\hline Aluminum & 114 & Reynolds (Tuscaloosa, AL) & 1,300 & Transfer Truck & Can Sheet & $\begin{array}{l}\text { Local broker (Northampton) upgrades } \\
\text { into bales \& markets to ALCOA, IN }\end{array}$ \\
\hline Steel & 33 & (Cockeysville, MD) & 570 & Transfer Trucks & Steel & \\
\hline Tin & 3,433 & Detinner (Pittsburgh, PA) & 600 & Rail & & \\
\hline \multicolumn{7}{|l|}{ Plastics } \\
\hline PET & 53 & Processor (New Jersey) & 220 & Transfer Trucks & $\begin{array}{l}\text { Fiber Products: pillows, park } \\
\text { (e.g., 4-benches) }\end{array}$ & Other Markets: Albany, NY; Springfield, MA; \\
\hline HDPE & 293 & Local Processor (Worcester, MA) & 55 & Transfer Trucks & Pellets - Bottles & Other Markets: Baltimore, MD; Canada \\
\hline \multicolumn{7}{|l|}{ Paper } \\
\hline News & 25,396 & Board Mill (Albany, NY) & 85 & Transfer Trucks & Linerboard; newspaper & Montreal, Canada \\
\hline Corrugated & 2,636 & Southeastern CT & 75 & Transfer Trucks & Boxboard & \\
\hline Cartons & 84 & Albany, NY & 85 & Transfer Trucks & Tissue & \\
\hline
\end{tabular}


Table 4: Collection and Disposition of HHW in FY 1993

\begin{tabular}{|c|c|c|c|c|c|}
\hline Type of HHW & $\begin{array}{l}\text { Cont } \\
\text { Size } \\
\text { (Gal.) }\end{array}$ & $\begin{array}{l}\text { No. } \\
\text { Cont. }\end{array}$ & Tons & $\begin{array}{l}\text { Percent } \\
\text { of Total }\end{array}$ & Disposition \\
\hline Acids (Lab Pack) & 55 & 1 & 0.11 & 0.75 & Aqueous Treated \\
\hline Alkalines (Lab Pack) & 55 & 1 & 0.11 & 0.75 & Aqueous Treated \\
\hline Oxidizers & 55 & 1 & 0.11 & 0.75 & Aqueous Treated \\
\hline Oxidizers & 5 & 1 & 0.01 & 0.07 & Aqueous Treated \\
\hline Alkalines (Lab Pack) & 55 & 1 & 0.11 & 0.75 & Aqueous Treated/Landfilled \\
\hline Consolidated Liquids (with PCB's) & 55 & 1 & 0.22 & 1.51 & Incinerated \\
\hline Flamable Liquids Can't Be Consolidated & 55 & 25 & 5.50 & 37.66 & Incinerated \\
\hline Organics (Lab Pack) & 16 & 9 & 0.29 & 1.97 & Incinerated \\
\hline Alkalines (Lab Pack) & 16 & 2 & 0.06 & 0.44 & Incinerated \\
\hline Water Reactive Compounds & 5 & 1 & 0.01 & 0.03 & Incinerated \\
\hline Alkalines (Lab Pack) & 5 & 1 & 0.01 & 0.07 & Incinerated \\
\hline Organics (Lab Pack) & 5 & 1 & 0.01 & 0.07 & Incinerated \\
\hline Flamables (Lab Pack) & 5 & 2 & 0.02 & 0.14 & Incinerated \\
\hline Pesticides (Lab Pack) & 55 & 1 & 0.11 & 0.75 & Incinerated/landfilled \\
\hline Pesticides (Lab Pack) & 16 & 1 & 0.03 & 0.22 & Incinerated/landfilled \\
\hline Organics (Lab Pack) & 55 & 2 & 0.22 & 1.51 & Landfilled \\
\hline Asbestos Containing Items & 55 & 1 & 0.04 & 0.27 & Landfilled \\
\hline Aerosol Cans & 55 & 1 & 0.04 & 0.27 & Landfilled \\
\hline Household Batteries & 5 & 2 & 0.03 & 0.21 & Landfilled \\
\hline Consolidated Liquids & 55 & 2 & 0.44 & 3.01 & Recyced as Fuel \\
\hline Consolidated Oil & 55 & 11 & 2.27 & 15.54 & Recyced as Fuel \\
\hline Consolidated Paint & 55 & 3 & 0.62 & 4.24 & Recyced as Fuel \\
\hline Automobile Batteries & & 200 & 0.90 & 6.16 & Recycled \\
\hline Empty Metal (e.g., Paint) Cans & & & 1.00 & 6.85 & Recycled \\
\hline Latex Paints & & & 1.13 & 7.70 & Recycled \\
\hline Solvent Based Paints & & & 1.21 & 8.29 & Recycled \\
\hline Totals & & & 14.60 & 100.00 & \\
\hline
\end{tabular}

1. Telephone conversation with Mr. William Connors, Clean Harbors of Natick, Inc., May 25, 1994.

2. "Paint Collection Tally," The Green Paint Company, May 1, 1993. 
was recycled as a fuel. Thirty-one percent was recycled as paint, and the balance of $25 \%$ was recycled to recover metals and plastic.

\section{Cost of MSW Management in Springfield}

\section{Summary of Results}

Of the 61,230 tons of MSW managed within the city, approximately 59,900 tons were analyzed ("Analyzed MSW") to determine the cost of Springfield's IMSWM system. The cost to manage the HHW is treated separately.

\section{Overall Program Costs}

The total FY 1993 gross cost to manage Analyzed MSW was about $\$ 9.72$ million. The cost less revenues received from the sale of materials and energy, was $\$ 7.17$ million, or about $\$ 120$ per ton. This net cost breaks downs to, in rounded numbers:

\begin{tabular}{||lccc||}
\hline Category & Tonnage & $\begin{array}{c}\text { Net Cost } \\
\text { (\$ millions) }\end{array}$ & Net Cost Per Ton \\
\hline Garbage & 44,700 & $\$ 5.60$ & $\$ 125$ \\
Recyclables & 7,580 & $\$ 1.01$ & $\$ 136$ \\
Yard Waste & 6,810 & $\$ 0.38$ & $\$ 57$ \\
Bulky Waste & 807 & $\$ 0.16$ & $\$ 197$ \\
Total/Average & 59,900 & $\$ 7.17$ & $\$ 120$ \\
\hline
\end{tabular}

The FY 1993 cost of managing about 15 tons of HHW was approximately $\$ 33,600$, or more than $\$ 2,200$ per ton.

As shown in Figure 9, the WTE facility is the most significant factor in the total gross cost of the Springfield IMSWM system, but collection costs become most significant when system revenues are considered. . Figure 10 shows the allocation of net costs to the key functional areas (i.e., collection, landfill, and general and administrative G\&A) for each of the program areas. Note that, with the exception of the management of garbage and HHW, collection costs amount to about half of the management costs. In the case of garbage, the cost of the WTE facility is about equal to that of collection.

\section{Program Incremental Costs}

The incremental cost for each resource recovery program, i.e., the cost (or savings) associated with adding the program to the IMSWM system, is the difference between the cost of managing all of the MSW with and without the inclusion of that program. The Program Incremental Cost (or Savings) is, therefore, an appropriate measure on the cost of managing MSW. The FY 1993 Program Incremental Cost (Savings) for each of the city's resource recovery programs was, in rounded numbers: 


\begin{tabular}{|l|c|c|c|}
\hline & & \multicolumn{2}{|c|}{$\begin{array}{c}\text { Incremental Cost } \\
\text { (Savings) }\end{array}$} \\
\cline { 2 - 4 } Program & Tonnage & Dollars & \$ Per Ton \\
\hline Waste-to-Energy & 45,677 & $\$ 322,500$ & $\$ 7$ \\
Curbside Recycling & 6,958 & $\$ 774,500$ & $\$ 111$ \\
Yard Waste Composting & 7,515 & $\$ 274,000$ & $\$ 36$ \\
Office Paper Recycling & 22 & $\$ 1,500$ & $\$ 68$ \\
White Goods Recycling & 509 & $\$(41,300)$ & $\$(81)$ \\
\hline
\end{tabular}

In addition to the incremental cost or savings that can be attributed to each of the resource recovery programs, each of them contributes resources to the economy and reduces the use of available landfill space. These attributes are summarized in Table 5. 
Figure 9: Allocation of Total Costs For IMSWM System in FY 1993

$$
\text { Allocation by Functional Area }
$$

(Cost to Manage 59,900 Tons of Analyzed MSW)

Gross Cost is $\$ 9,720,000$

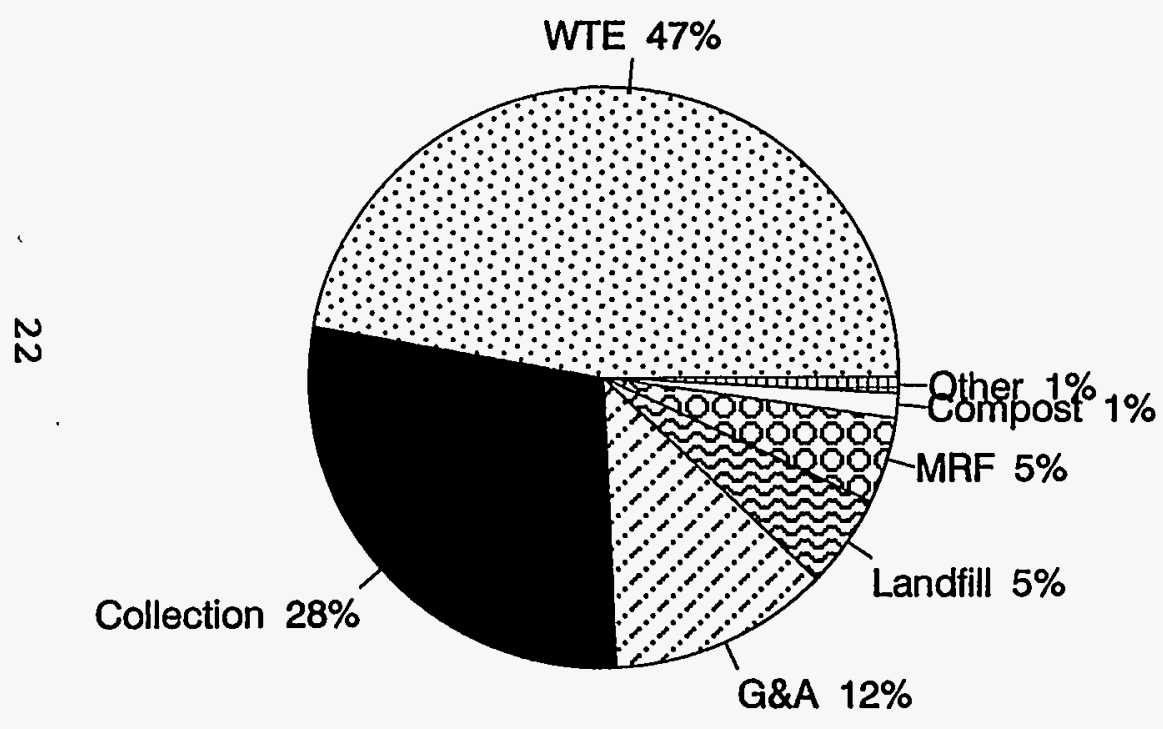

Net Cost is $\$ 7,170,000$

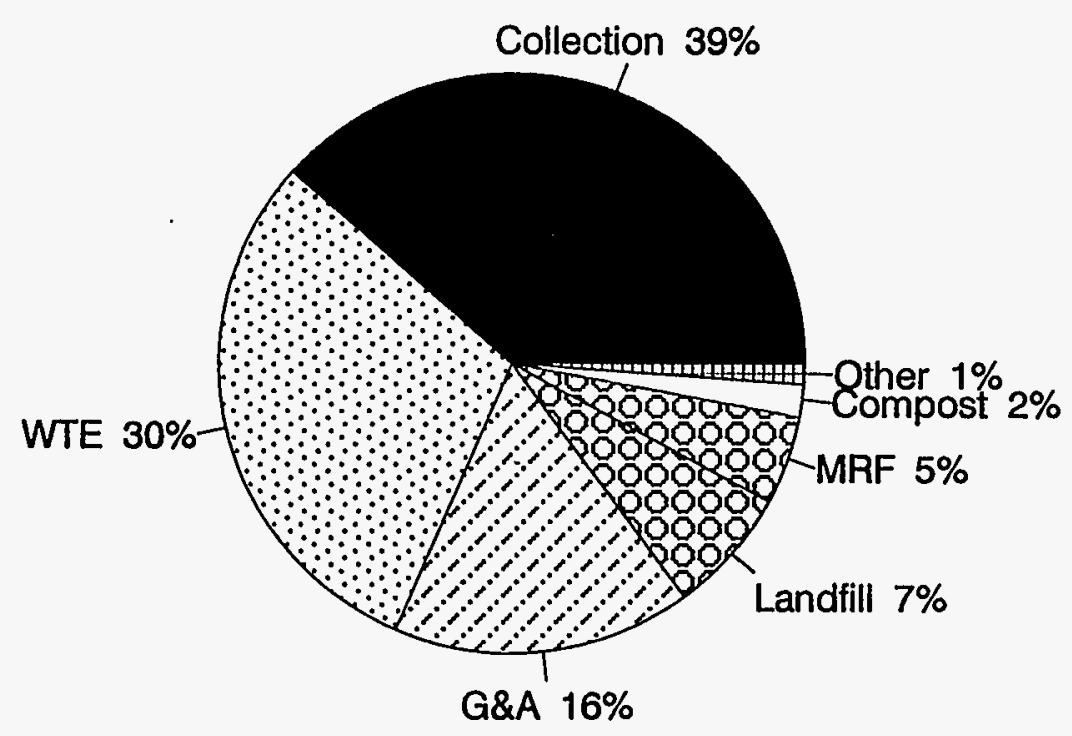


Figure 10: Allocation of Net Costs to Manage MSW in Springfield Allocation by Functional Area

\section{GARBAGE}

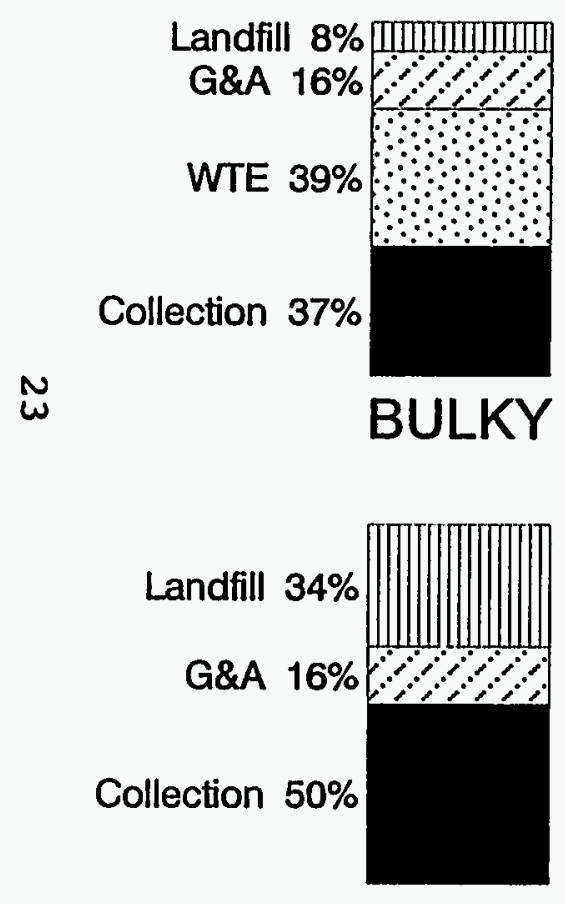

RECYCLABLES

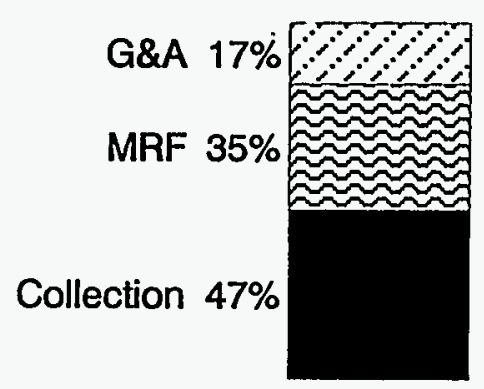

HHW

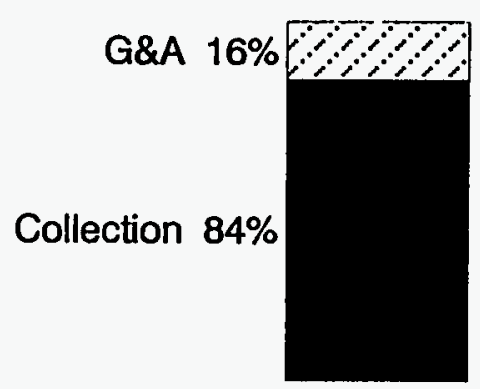

\section{YARD WASTE}

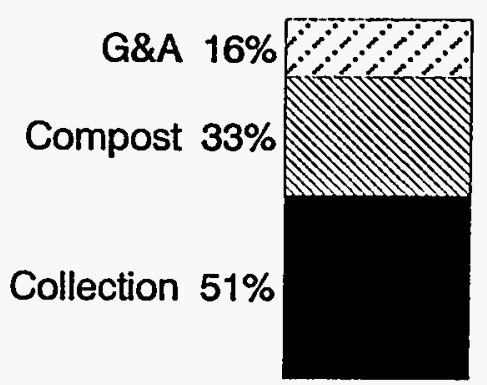

MSW

Landfill $7 \%$ [I]Mm

G\&A $16 \% \because \because$

Compost $2 \%$

WTE $30 \%$

MRF $5 \%$

Collection $39 \%$ 
Table 5: Springfield FY 1993 Rresource Recovery Program Incremental Costs/Effectiveness

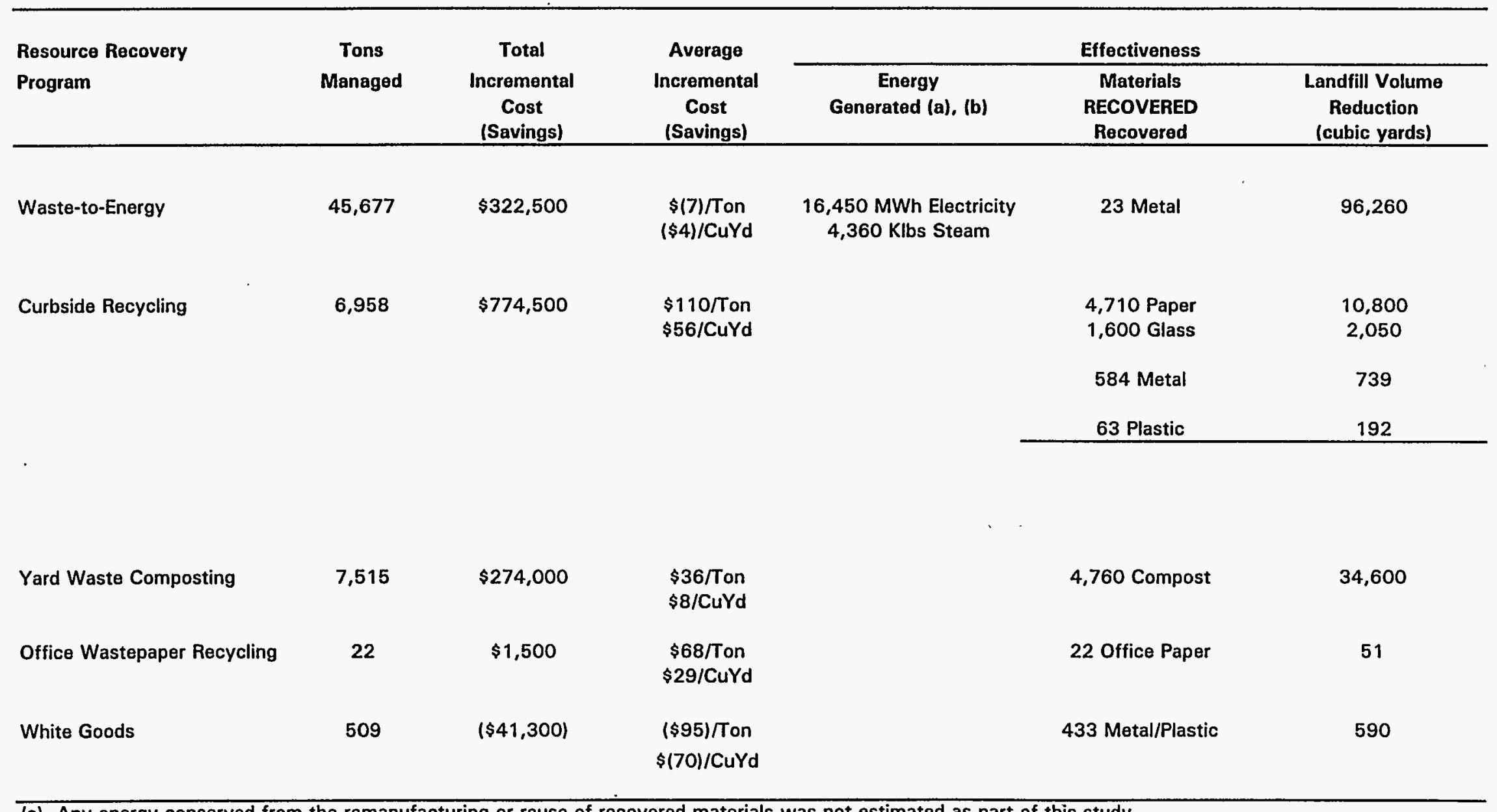

(a) Any energy conserved from the remanufacturing or reuse of recovered materials was not estimated as part of this study.

(b) The energy generated from a WTE facility is less than the energy conserved. 


\section{Energy Usage Analysis}

The forms of energy used within Springfield's IMSWM system are gasoline, diesel fuel, propane, number 2 fuel oil, and electricity. The energy is consumed by collection vehicles, the WTE facility, the MRF, the yard waste composting operation, the white goods processing operation, the Bondi's Island Landfill, and the transfer vehicles used for hauling recyclables to market.

\section{Summary of Results}

In FY 1993, the Springfield IMSWM system configuration resulted in the consumption of the equivalent of approximately 670,000 gallons of diesel fuel. Almost $80 \%$ of this energy was for the processing of MSW at the resource recovery facilities. This energy consumption was offset by about 1.16 million equivalent gallons of diesel fuel conserved as a result of the net energy produced by the WTE facility. Thus, on a net basis, the Springfield IMSWM system resulted in the conservation of the equivalent of approximately 500,000 gallons of diesel fuel.

As shown in Table 6, there were significant differences among the per-ton energy consumptions for managing the various categories of MSW. However, without taking into account the energy produced at the WTE, energy consumption for managing garbage and curbside recyclables was similar (5.2 and 4.5 gallons/ton, respectively).

\section{Environmental Regulations and Permit Requirements}

The costs of compliance with environmental regulations and their related permit requirements discussed in this section are reflected in the costs and energy consumption levels reported in this case study. As of FY 1993, none of the components of Springfield's IMSWM system was out of compliance with any federal, state, environmental, or safety laws or regulations.

\section{Overview of Federal Environmental Legislation and Regulations}

Embodied in many federal environmental laws is an implicit federal-state partnership whereby the federal government sets the agenda and standards for pollution abatement while the states carry out the day-to-day activities of implementation and enforcement.

The Clean Air Act, most recently amended in 1990, established programs for protecting public health and the environment from exposure to toxic air pollutants. The Clean Water Act, most recently amended in 1987, is the principal federal law protecting the nation's waterways from pollution. The Safe Drinking Water Act, most recently amended in 1988, established programs for protecting public drinking water systems from harmful contaminants. The Resource Conservation and Recovery Act (RCRA) of 1976, most recently amended in 1992, is the main piece of federal legislation addressing landfill disposal regulation.

In February 1991, the U.S. Environmental Protection Agency (EPA) issued final rules for municipal waste combustors in response to the Clean Air Act. These rules, commonly referred 
Table 6: Energy Consumption to Collect Garbage, Bulky Waste, Office Paper, and Recyclables in Springfield (FY 1993)

\begin{tabular}{lrrrrr}
\hline Variables & Garbage & $\begin{array}{c}\text { Bulky } \\
\text { Waste }\end{array}$ & $\begin{array}{c}\text { Yard } \\
\text { Waste }\end{array}$ & $\begin{array}{c}\text { Office } \\
\text { Paper }\end{array}$ & Recyclables \\
\hline Tons Collected & 44,707 & 1,316 & 6,814 & 22 & 7,048 \\
Niesel Fuel Consumed (gallons) & 46,598 & 3,617 & 3,061 & 127 & 14,017 \\
Millions of Btus & 6,820 & 530 & 450 & 20 & 2,050 \\
Gallons per Ton & 1.0 & 2.7 & 0.4 & 5.8 & 2.0 \\
\hline
\end{tabular}

Note: Conversion to millions of Btus assumes 146,390 Btus per gallon.

Source: City of.Springfield - DPW, "Determination of Fiscal Year 1993 Total Costs for Various

Solid Waste Programs," Computer Printout, August 20, 1993. 
to as the New Source Performance Standards (NSPS), apply to municipal waste combustors with capacities of 250 tons per day or greater, and whose construction, reconstruction, or modification commenced after December 20,1989. The NSPS establish maximum emission levels for new or extensively modified major stationary sources. These emission levels were determined by "best adequately demonstrated" continuous control technology analysis. In addition to the NSPS, the EPA also proposed emissions limitations for existing (i.e., constructed, reconstructed, or modified prior to December 20, 1989) municipal waste combustors.

The owner/operator of a proposed municipal waste combustor must apply for a Prevention of Significant Deterioration (PSD) permit and conduct a Best Available Control Technology (BACT) analysis to determine the applicable level of emissions control. BACT analysis evaluates the energy, environmental, and economic impacts of various alternative control technologies. The PSD permit requirements reflect the principle which holds that areas where the air quality is better than required by the national ambient air quality standards (NAAQS) established for six criteria pollutants (ozone, sulfur only dioxide, $\mathrm{NO}_{\mathrm{x}}$, carbon monoxide, lead, and particulates) should be protected from significant new air pollution, even if the NAAQS would not be violated by a proposed new source. Areas not meeting NAAQS are called nonattainment areas and are subject to more stringent control requirements determined by "Reasonable Available Control Technology" (RACT).

Emissions from municipal waste combustors, in addition to meeting allowable limits, must also be monitored by the facility owner/operator. Monitoring requirements for existing facilities include continuous emissions monitoring for carbon monoxide and sulfur dioxide. Annual stack testing must be conducted for particulate matter, dioxin/furans, hydrogen chloride, and opacity.

Pursuant to the Clean Water Act, a solid waste management facility cannot cause a discharge of pollutants that is in violation of the requirements of the National Pollutant Discharge Elimination System (NPDES) into U.S. waters. The states are responsible for establishing water quality standards and are authorized to issue discharge permits. The NPDES permit requires the source to attain technology-based effluent limits, "best practicable control technology," and "best available technology."

Pursuant to the Safe Drinking Water Act, a facility or practice cannot contaminate an underground drinking water source beyond the solid waste management facility boundary or beyond an alternate boundary. The primary enforcement responsibility lies with the states, provided they adopt regulations as stringent as the federal requirements and develop adequate procedures for enforcement.

Pursuant to RCRA, criteria were established to determine which solid waste disposal facilities and practices pose a reasonable probability of adverse effects on public health or the environment. The objective of these criteria is to mitigate adverse effects through the protection of floodplains, endangered species, surface water, and groundwater.

Subtitle D of RCRA primarily addresses nonhazardous waste, whereas Subtitle C of RCRA addresses hazardous waste disposal. In October 1991, the EPA promulgated revised Subtitle D regulations applicable to MSW landfills, with an effective date of October 1993. In general, the new regulations require liners, leachate collection, groundwater monitoring, and corrective action at municipal landfills. ${ }^{2}$

a On October 1, 1993, the federal criteria for MSW landfills under subtitle D of RCRA were amended to extend the date of compliance for small landfills to April 9, 1994, and to delay the effective date of subpart G, Financial Assurance, to April 9, 1995, for all MSW landfills. In addition, the MSW landfill criteria were amended by removing the exemption from the groundwater monitoring requirements and by delaying the date for compliance with all 
The management of ash from municipal waste combustors is also governed by regulations established pursuant to RCRA. Much controversy surrounds the toxicity of incinerator ash and whether it should be classified as a hazardous waste under Subtitle C of RCRA, as a non-hazardous waste under Subtitle D of RCRA, or as a special waste. In 1991, the EPA began requiring the use of the Toxic Characteristic Leaching Procedure (TCLP) to determine the toxicity of ash. During FY 1993, municipal .waste combustor ash was regulated under Subtitle D as a "special waste" that requires special handling regardless of the TCLP results concerning toxicity. In the absence of sufficient federal guidance on municipal waste combustor ash disposal, some states took the lead in developing requirements and rules. ${ }^{b}$

Other federal regulatory agencies with permitting oversight of solid waste management facilities include: the Federal Aviation Administration, which reviews processing plants that require tall emission stacks, and the Federal Energy Regulatory Commission, which reviews processing plants that generate electric power.

\section{Overview of State and Local Environmental Regulations}

At a minimum, state regulators are required to adopt and enforce the federal requirements, but they may choose to impose more stringent or more extensive requirements.

In 1987, the Commonwealth enacted the Solid Waste Act, whose public purpose is to "eliminate, mitigate, and prevent nuisances and adverse public health effects associated with the collection, processing and disposal of solid waste." The Massachusetts DEP is responsible for the execution and enforcement of the provisions of this act. "Protection of public health, safety, and the environment is primarily the prevention of pollution from the site, but also encompasses the operation of the facility within an integrated solid waste management system which maximizes material reuse and the conservation of energy." .

The Massachusetts regulations require MSW landfills and waste-to-energy facility owners/operators to provide for recycling or composting of a minimum of $25 \%$ by weight of the average yearly amount of MSW the facility is approved to accept.

Specific restrictions on the disposal of certain components of the solid waste stream-such as lead batteries, tires, and yard waste-are listed in Table 7. MSW landfills or WTE facilities cannot accept the restricted material except to handle, recycle, or compost the material.

The city of Springfield regulates solid waste practices pursuant to the ordnance on Solid Waste, Litter and Weeds of the City Ordinances (1986) and subsequent amendments. In 1986, through an amendment to this chapter, the city established a mandatory curbside recycling program to take effect on the commencement of the commercial operation of the MRF (January 1990). The program mandates separation of aluminum, glass, ferrous metal cans, newspaper, and corrugated paper from MSW into recycling receptacles provided to each household.

requirements of the MSW landfill criteria for 2 years for owners and operators of MSW landfill units in arid and remote areas that meet the qualifications of the small landfill exception in the MSW landfill criteria. (Federal Register, "Solid Waste Disposal Facility Criteria; Delay of Compliance and Effective Dates," Vol. 58, No. 189, pages 51536-51548, 1993.)

b On May 2, 1994, the U.S. Supreme Court ruled that ash from municipal waste combustors is not exempt from the Subtitle C requirements of RCRA as is MSW. Under RCRA, regular testing of ash, principally for toxic metals, lead, and cadmium, will be required. Ash deemed to be bazardous must be disposed of in licensed hazardous waste disposal facilities that protect groundwater. 
In 1988, the city established a program for the mandatory separation of certain compostible leaf and yard waste material from garbage and the collection of these compostible leaf and yard waste materials at the curbside. During the leaf and yard waste collection season, the leaf and yard waste must be placed in paper leaf bags or barrels at the curbside.

In 1992, the city adopted regulations that require the licensing of bulk and waste haulers who engage in collecting, removing, hauling, or transporting any garbage, refuse, rubbish, hazardous waste, or other waste in the city.

\section{Permit Requirements for Each IMSWM System Facility}

The DEP requirements for new and existing solid waste management facilities are (a) a valid site assignment, (b) a solid waste management facility permit, (c) authorization to construct the facility, and (d) authorization to operate the facility.

Waste-to-Energy Facility

In 1983, the Agawam Board of Health issued the Site Assignment for the WTE facility. The Massachusetts Environmental Policy Act approval by the Secretary of Environmental Affairs was issued in 1984. The DEP issued the PSD permit and Permit to Construct and Operate in 1985. In 1986, the DEP reissued the PSD permit to the new facility owner, Fluor Resource Recovery. In 1993, the DEP approved an increase of the daily facility MSW throughput capacity from 360 TPD to 408 TPD, with no increase in the annual maximum MSW throughput capacity. The change in allowable daily throughput capacity did not require additional emissions control or change in permitted emissions rates for any pollutants except $\mathrm{NO}_{\mathrm{x}}$ and lead. Permit conditions of the PSD permit are outlined on Table 8, Emission Limits.

The WTE facility is permitted to discharge wastewater into the Regional Wastewater Treatment Facility in accordance with the city's Sewer Use Ordinance and the allowable discharge limitations listed on Table 9.

Table 10 summarizes the permitting activities for the WTE facility from November 30, 1983, through June 17, 1993.

The WTE facility was in compliance with all DEP permit requirements during FY 1993.

\section{Materials Recovery Facility}

In accordance with the Site Assignment Regulations, the DEP determined that a site assignment was not necessary for the MRF, which handles only presorted recyclable materials. Consistent with the Regulations' intent to promote recycling, MRF operations are considered "benign" and therefore are not subject to the myriad of regulations applicable to other solid waste management facilities, such as MSW landfills and WTE facilities.

Yard Waste Composting

Yard waste composting facilities are conditionally exempt from Site Assignment Regulations. The city's yard waste composting operation is registered with the DEP. 
Table 7. Implementation Schedule for Waste Disposal Bans

\begin{tabular}{||l|c|l||}
\hline \hline Restricted Material & $\begin{array}{c}\text { Effective Date } \\
\text { of Restriction }\end{array}$ & Restriction on Disposal \\
\hline Lead Batteries & $12 / 31 / 90$ & Ban on disposal or incineration \\
Leaves & $12 / 31 / 91$ & Ban on disposal or incineration \\
Tires & $12 / 31 / 91$ & $\begin{array}{l}\text { Ban on disposal of whole tires only } \\
\text { at landfills. Tires must be shredded } \\
\text { prior to disposal in landfills. }\end{array}$ \\
White Goods & $12 / 31 / 91$ & Ban on disposal or incineration \\
Other Yard Waste & $12 / 31 / 92$ & Ban on disposal or incineration \\
POSTCONSUMER & $12 / 31 / 92$ & Ban on disposal or incineration \\
RECYCLABLES & $12 / 31 / 92$ & Ban on disposal or incineration \\
Aluminum Containers & $12 / 31 / 94$ & Ban on disposal or incineration \\
Metal or Glass Containers & $12 / 31 / 94$ & Ban on disposal or incineration \\
Single Polymer Plastics & \multicolumn{2}{|l}{} \\
Recyclable Paper &
\end{tabular}

Source: 310 CMR 19.07-Waste Control-Department of Environmental Protection Solid Waste Management.

Table 8. Emissions Limits-Springfield RRF

\begin{tabular}{|l|c|c|}
\hline Pollutant & PSD Limits & Amendment $^{\text {b] }}$ \\
\hline Nitrogen Oxides $\left(\mathrm{NO}_{x}\right)$ & $0.33 \mathrm{lb} / \mathrm{MMBtu}$ & $0.242 \mathrm{lb} / \mathrm{MMBtu}$ \\
Sulfur Dioxide $\left(\mathrm{SO}_{2}\right)$ & $0.13 \mathrm{lb} / \mathrm{MMBtu}$ & \\
Particulates (TSP) & $0.03 \mathrm{~g} /$ dscf corrected & \\
& to $12 \% \mathrm{CO}_{2}$ & \\
Lead & $4.80 \times 10^{-3} \mathrm{lb} / \mathrm{MMBtu}$ & $1.0 \times 10^{-3} \mathrm{lb} / \mathrm{MMBtu}$ \\
Beryllium & $1.2 \times 10^{-6} \mathrm{lb} / \mathrm{MMBtu}$ & \\
Mercury & $2.6 \times 10^{-4} \mathrm{lb} / \mathrm{MMBtu}$ & \\
Opacity & $\geq 20 \%$ & \\
\hline
\end{tabular}

- PSD \#PV-85-IN-006, 6/27/86.

b Burn Rate Increase Amendment, 6/17/93. 
Table 9. Wastewater Discharge Limitations-Springfield RRF

\begin{tabular}{||c|c|}
\hline Pollutant & Units (mg/l) \\
\hline Total Chromium & 0.133 \\
Total' Zinc & 0.667 \\
Total Iron & 35.0 \\
Total Manganese & 1.0 \\
Total Sulfide & 24.0 \\
Priority Pollutants & No Detectable Amounts \\
\hline
\end{tabular}

Table 10. Permitting Activity-Springfield RRF

\begin{tabular}{|c|c|c|}
\hline Permit/Approval Date & Review Agency & Description of Permit/Approval \\
\hline $11 / 30 / 83$ & Agawam Board of Health & Site Assignment \\
\hline $12 / 28 / 84$ & $\begin{array}{c}\text { Secretary of Environmental } \\
\text { Affairs }\end{array}$ & Certification of the Final EIR \\
\hline $12 / 27 / 85$ & DEP & PSD \\
\hline $12 / 27 / 85$ & DEP & Permit to Construct \\
\hline $6 / 27 / 86$ & DEP & Land Use \\
\hline $6 / 27 / 86$ & DEP & PSD-Reissued \\
\hline $5 / 4 / 88$ & DEP & CEM Approval \\
\hline $9 / 23 / 88$ & DEP & $\begin{array}{c}\text { Amended APC Equipment } \\
\text { Approval }\end{array}$ \\
\hline $10 / 3 / 88$ & DEP & $\begin{array}{l}\text { Emission Compliance Test } \\
\text { Protocol Approval }\end{array}$ \\
\hline $4 / 28 / 89$ & DEP & $\begin{array}{l}\text { Deflow Prevention Device } \\
\text { Approval }\end{array}$ \\
\hline $6 / 27 / 91-11 / 27 / 92$ & DEP & Permit to Operate (ATO) \\
\hline $12 / 2 / 92$ & DEP & Permit for the Burning of Tires \\
\hline $11 / 4 / 91$ & DEP (Air Quality) & $\begin{array}{c}\text { Consent Order-Miscellaneous } \\
\text { Issues }\end{array}$ \\
\hline $2 / 8 / 91$ & DEP & Consent Order-Hg Emissions \\
\hline $5 / 28 / 93$ & DPW & Wastewater Discharge Permit \\
\hline $6 / 17 / 93$ & DEP & $\begin{array}{l}\text { Conditional Approval of Burn } \\
\text { Rate Increase (PSD Modification) }\end{array}$ \\
\hline
\end{tabular}


Permitting activities for the Bondi's Island MSW landfill began in 1966, when the West Springfield section received its site assignment. The Agawam Board of Health issued the site assignment for the Agawam section of the landfill in 1968. Massachusetts Environmental Policy Act approval was issued in 1985. In 1992, the city of Springfield applied for an existing facility permit.

In 1989, the city, SRRI, and Department of Environmental Protection entered into a compliance order for additional dewatering of ash residue entering the landfill from the WTE facility. An ash building was constructed in 1992 to accomplish this function and to satisfy the order.

During FY 1993, the Bondi's Island Landfill operated in compliance with all other permit conditions. 


\section{Appendix A}

\section{References}

\section{General}

City of Springfield, "Mandatory Yard and Leaf Waste Composting," An Ordinance Amending Title 7, Chapter 7.16 of the Revised Ordinances of the City of Springfield, 1986, as Amended, October 7, 1988.

City of Springfield, "Mandatory Recycling," An Ordinance Amending the Revised Ordinances of the City of Springfield, Chapter 9, Section 4, Subsection 7.16.040, June 19, 1886.

City of Springfield, "Case Study in Integrated Solid Waste Management," Paper presented at the tenth annual meeting of the New England Resource Recovery Conference and Exposition, Springfield, MA, June 5, 1991.

City of Springfield, "May 1993 Household Hazardous Waste Collection Preliminary Report," undated.

City of Springfield, "1992 Yard Waste Processing Equipment Grant Application to the Commonwealth of Massachusetts," February 11, 1992.

City of Springfield, "Leaf and Yard Waste Composting Registration Form," Commonwealth of Massachusetts, Department of Environmental Protection, Division of Solid Waste Management, February 11, 1992.

CSI, "MSW Management Assessment Model," Collection Submodel, 1994.

DPW, "Solid Waste Management Plan," March 1994.

DPW, "Springfield Yard Waste Composting Project Summary," undated.

Letter from Michael Pattavina, Project Director, Springfield DPW, to the Editor of the Union News, May 17, 1993, concerning the HHW collection day held on May 1, 1993.

The Green Paint Company, "Paint Collection Tally," May 1, 1993.

Telephone conversation with Mr. William Connors, Clean Harbor of Natick, Inc., May 25, 1994.

Project Management Associates, Inc., "Review of Alternative Disposal Options-City of Springfield, Massachusetts, November, 1993.

\section{Environmental Laws and Regulations}

Code of Massachusetts Regulations (CMR), Title 310-Department of Environmental Protection, Chapter 16-Site Assignment Regulations for Solid Waste Facility; Adopted September 1988; May 1990.

CMR, Title 310-DEP, Chapter 19-Solid Waste Management; Adopted July 1990; Amended October 1990, July 1992. 
Massachusetts General Laws (MGL), Chapter 16-Department of Public Works, Solid Waste Disposal; Enacted 1969; most recent amendment 1990.

MGL, Chapter 111-Public Health, Enacted 1955; most recent amendment 1992.

MGL, Chapter 21H—DEP, Solid Waste Facilities, Enacted 1987; most recent amendment 1992.

DEP, A Citizen's Guide to Site Assignment Regulations for Solid Waste Management Facilities, 310 CMR 16.00, October 1988.

SEA Consultants, Inc., "City of Springfield, Existing Facility Permit Application, Bondi Island Landfill," July 1992.

City of Springfield, Ordinances-Title 7, Chapter 7.16 Solid Waste, Litter, and Weeds, 1986.

City of Springfield, Ordinances-Title 7, Chapter 7.16.040 Mandatory Recycling, June 19, 1986.

City of Springfield, Ordinances-Title 7, Chapter 7.16.041 Mandatory Leaf and Yard Waste Composting, June 14, 1988.

City of Springfield, Ordinances-Title 7, Chapter 7.17 Bulk and Waste Hauling Services, August 18, 1992. 


\section{Appendix B}

\section{Glossary of Terms}

ALLOCATED COST (\$/year):

AVERAGE PROGRAM INCREMENTAL COST (SAVINGS) (\$/ton):

BULKY WASTE:

COMMERCIAL MSW:

GARBAGE:

HAZARDOUS WASTE:
That portion of the Total Cost that is expended or apportioned to a specific activity such as the management of garbage, trash, recyclables, yard waste, or household hazardous waste.

AVERAGE COST ( $\$$ ton):Total or Allocated Cost divided by the tons of MSW, garbage, trash, recyclables, or yard waste, as appropriate.

The Program Incremental Cost divided by the number of tons of materials diverted from the landfill by the program.

Oversized items, including white goods and furniture, that have been separated from the MSW stream for separate collection.

MSW that is generated by sources other than households, including businesses (e.g., offices, restaurants, retail stores, and industry), institutions (e.g., schools and government establishments), and public areas (e.g., train stations, airports, and litter from roadside).

Garbage is all MSW exclusive of sourceseparated trash, recyclables, yard waste, household hazardous waste, and bulky waste.

Waste which because of its quantity, concentration, or physical, chemical, or infectious characteristics, may pose a substantial present or potential hazard to human health or the environment when improperly treated, stored, transported, disposed of, or otherwise managed and is defined as hazardous in accordance with federal and state laws. Does not include Household Hazardous Waste. 
HOUSEHOLD HAZARDOUS WASTE (HHW):

INTEGRATED SOLID WASTE MANAGEMENT:

MANAGED MSW:

MARGINAL COST (SAVINGS) (\$/ton):

MARGINAL COST (SAVINGS) OF SUBSTTTUTION (\$/ton):

MATERIALS RECOVERY:

MUNICIPAL SOLID WASTE (MSW):
Materials that are separated from Residential MSW as household hazardous waste for separate collection and treatment. Such materials may include paints and solvents, pesticides, herbicides, and propane tanks.

A practice of using several (i.e., two or more) alternative waste management techniques to treat, process, and/or dispose of the MSW stream. Alternative waste management techniques include source reduction, recycling, composting, combusting, and landfilling.

Portion of the MSW stream for which the cost of collecting, transferring, hauling, processing, combusting, marketing, and/or disposing of such waste is known or can be reasonably estimated.

The cost (savings) of managing an additional ton of MSW, garbage, trash, recyclables, or yard waste.

The net cost (savings) of managing an additional ton of recyclables or yard waste less the savings (cost) of managing one less ton of garbage.

A term describing the extraction and use of materials from a waste stream.

Nonhazardous solid wastes generated by households, commercial and business establishments, institutions, and light industry; it excludes industrial process wastes, agricultural wastes, mining wastes, construction and demolition debris, offal, sludges, and ashes, except ashes derived from the combustion of MSW. In practice, specific definitions vary across jurisdictions. 
PROGRAM INCREMENTAL COST

(SAVINGS) (\$/year):

RECOVERED MATERIALS:

RECYCLABLE MATERIALS OR RECYCLABLES:

RECYCLE:

RESIDENTIAL MSW:

RESIDUE:

RESOURCE RECOVERY:

SECONDARY MATERIAL:

SELF-HAUL:
The difference between the cost of managing MSW with the inclusion of a particular program and the cost of managing MSW without that program (e.g., curbside collection, processing, and marketing of recyclables.)

Recyclable materials that are recovered from MSW and may also include some contamination.

Materials that still have useful physical or chemical properties after serving their usefulness for a given individual or firm and can, therefore, be reused or recycled for the same or other purposes.

To convert discarded materials into useful products through reuse and remanufacturing.

MSW that is generated by households.

That portion of processed MSW that is ultimately disposed of in a landfill.

A term describing the extraction and use of energy or materials from a waste stream.

A material that is used in place of a primary or raw material in manufacturing a product; often handled by dealers and brokers in "secondary markets."

The delivery of MSW or other wastes to an integrated MSW management system by a private firm or individual that is not under contract to a municipality, authority, utility, or other public entity responsible for MSW management to make such deliveries. 
TOTAL NET COST OR TOTAL COST (\$/year):

YARD WASTE:

WHITE GOODS:
The aggregate of all expenditures incurred to manage MSW, inclusive of general and administrative, planning, capital, collection, processing, transfer and haul, marketing, promotion and education, and disposal costs, less any revenues derived from resource recovery activities.

Vegetative material that is segregated from the MSW stream for separate collection and/or processing, including grass, prunings, plants, and small tree limbs, but excluding tree stumps, landclearing debris, and other large vegetative matter.

That portion of bulky waste which consists of large appliances, such as refrigerators, stoves, washing machines, and dryers. 


\section{Contents}

2. The City's Integrated Municipal Solid Waste Management System $\ldots \ldots \ldots \ldots \ldots$ 2-1

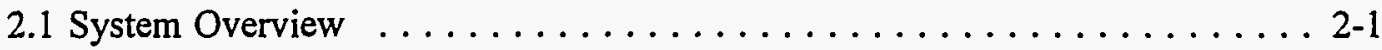

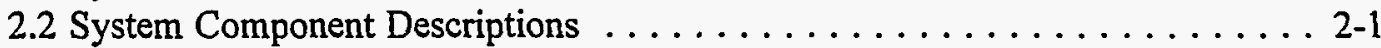

2.2.1 Collection ..................... 2-1

2.2.2 Materials Recovery Facility . . . . . . . . . . . 2-6

2.2.3 Waste-to-Energy Facility . . . . . . . . . . . . . . . 2-7

2.2.4 Yard Waste Composting Operation ............. 2-10

2.2 .5 Office Paper Recycling Program ... . . . . . . . . . 2-10

2.2.6 White Goods Preparation and Storage .............. 2-10

2.2.7 Household Hazardous Waste Collection Day ... . . . . . . 2-12

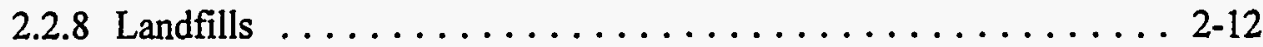

3. MSW Collected, Processed, and/or Disposed of in Springfield in FY $1993 \ldots \ldots$. . . 3-1

3.1 Garbage Collection, Combustion, and Disposal . . . . . . . . . . 3-1

3.2 Yard Waste Collection, Processing, and Compost Marketing . . . . . . . . 3-1

3.3 Recyclables Collection, Processing, and Marketing . . . . . . . . . . . . 3-4

3.4 Bulky Waste Collection, Processing, and Disposal . . . . . . . . . . 3-6

3.5 Collection and Disposal of HHW . . . . . . . . . . . . . . 6

4. Cost of MSW Management in Springifeld $\ldots \ldots \ldots \ldots \ldots \ldots \ldots \ldots \ldots \ldots$

4.1 Summary of Results . . . . . . . . . . . . . . .

4.1.1 Overall Program Costs . . . . . . . . . . . . . . 4 4-1

4.1.2 Program Incremental Costs . . . . . . . . . . . . 4-1

4.2 Apportionment of Waste Stream . . . . . . . . . . . . . . 4-4

4.3 Gross and Net Costs of Analyzed MSW Management . . . . . . . . . . . . 4-6

4.3.1 City Reported Costs . . . . . . . . . . . . . . . . 4 4-6

4.3.2 Adjustments to the Reported Costs and Assumptions

Made to Calculate Itemized Net Costs . . . . . . . . . . . 4-8

4.3.3 Determining the Net Cost of Managing Analyzed MSW . . . . . 4-10

4.4 Allocation of Costs by Functional Area . . . . . . . . . . . . . . 4-11

4.4.1 Cost of the Waste-to-Energy Facility . . . . . . . . . . 4-13

4.4.2 Cost of the Materials Recovery Facility . . . . . . . . . . . 4-14

4.4.3 Cost of the Compost Operation ................ . 4-14

4.4.4 Cost of Disposing of Waste at the Bondi's Island Landfill . . . . . 4-15

4.5 Allocation of Costs by Type of Waste . . . . . . . . . . . . 4-15

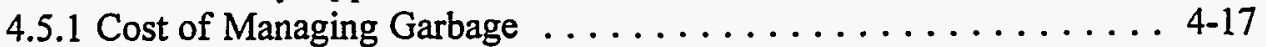

4.5.2 Cost of Managing Recyclables . . . . . . . . . . . . . . 4-17

4.5.3 Cost of Managing Yard Waste . . . . . . . . . . . . 4-17

4.5.4 Cost of Managing Non-Recyclable Bulky Waste . . . . . . . 4-17

4.5.5 Costs of Managing HHW . . . . . . . . . . . . 4-21 


\section{Contents (Continued)}

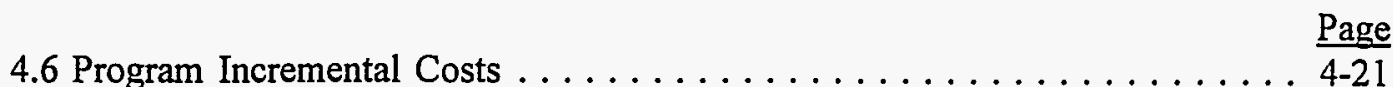

4.6.1 Waste-to-Energy Program . . . . . . . . . . . . . . . . 4-21

4.6.2 Curbside Recycling Program . . . . . . . . . . . . . . . 4 4-25

4.6.3 Yard Waste Composting Program . . . . . . . . . . . . . 4 4-27

4.6.4 Office Paper Recycling Program . . . . . . . . . . . . . . . . . 4-29

4.6.5 White Good Recycling Program . . . . . . . . . . . . 4-29

5. Energy Usage Analysis $\ldots \ldots \ldots \ldots \ldots \ldots \ldots \ldots \ldots \ldots \ldots \ldots \ldots \ldots \ldots \ldots \ldots$

5.1 Summary of Results . . . . . . . . . . . . . . . . 5-1

5.2 Collection Vehicle Energy Consumption . . . . . . . . . . . . 5-1

5.3 Energy Consumption at the MSW Processing and Disposal Facilities . . . . . 5-5

5.4 Energy Consumption to Transport Recovered Materials to Remanufacturers . . 5-7

5.5 Energy Consumed to Manage Garbage, Bulky Waste, White Goods, Yard

Waste, Office Paper, and Curbside Recyclables . . . . . . . . . . . . . . 5 5-9

5.6 Energy Production at the WTE Facility $\ldots \ldots \ldots \ldots \ldots \ldots \ldots . \ldots \ldots$

6. Environmental and Safety Regulations and Permit Requirements $\ldots \ldots \ldots \ldots \ldots$. . . .

6.1 Overview of Federal Legislation and Regulations . . . . . . . . . 6-1

6.2 Overview of State and Local Environmental Regulations . . . . . . . . . . 6-6

6.2.1 Permit Requirements for Each IMSWM System Facility . . . . . . . 6 6-9

6.2.1.1 Waste-to-Energy Facility . . . . . . . . . . . . . . . . 6-9

6.2.1.2 Materials Recovery Facility . . . . . . . . . . . . 6-10

6.2.1.3 Yard Waste Composting . . . . . . . . . . . 6-10

6.2.1.4 Bondi's Island Landfill . . . . . . . . . . . . . 6-10

6.3 Overview of Occupational Health and Safety Regulations . . . . . . . . 6-13

6.3 .1 Federal Regulations .................... 6-13

6.3.2 State and Local Safety Requirements ............. 6-14

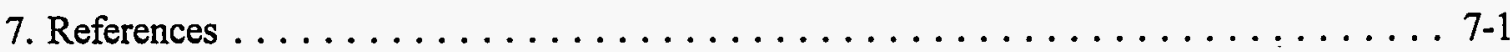

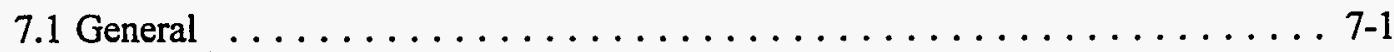

7.2 Environmental Laws and Regulations ............... 7-1

Appendix A: Glossary of Terms

Appendix B: Allocation of Costs and Result Tables

Appendix C: Methodology, Assumptions, and Data Used to Calculate Marginal

Costs and Program Incremental Costs

Appendix D: Capital Cost Calculations 


\section{List of Figures}

Figure 1-1: $\quad$ Map of the Commonwealth of

Figure 1-2: Counties of Massachusetts $\ldots \ldots \ldots \ldots \ldots \ldots \ldots \ldots \ldots \ldots \ldots$

Figure 2-1: $\quad$ MSW: Defined Constituents $\ldots \ldots \ldots \ldots \ldots \ldots \ldots \ldots \ldots \ldots$

Figure 2-2: Location of MSW Management Facilities in Springfield, Massachusetts . . 2-3

Figure 2-3: $\quad$ Site Plan for Bondi's Island $\ldots \ldots \ldots \ldots \ldots \ldots \ldots \ldots \ldots$

Figure 2-4: $\quad$ MRF Flow Diagram - Springfield, Massachusetts $\ldots \ldots \ldots \ldots \ldots \ldots$

Figure 2-5: Flow Diagram of the Waste-to-Energy Facility $\ldots \ldots \ldots \ldots \ldots$ 2-11

Figure 3-1: MSW Flow and Resource Recovery Diagram - Springfield, Massachusetts ......................... 3-3

Figure 3-2: $\quad$ Materials Recovered and Revenues Received in FY 1993 . . . . . . . . 3-7

Figure 4-1: Allocation of Total Costs for IMSWM System in FY $1993 \ldots \ldots$. . . . 4 4-2

Figure 4-2: $\quad$ Allocation of Net Costs to Manage MSW in Springfield . . . . . . . 4-3

Figure 4-3: $\quad$ Percent Gross O\&M and Capital Costs by Function in FY $1993 \ldots$. . . 4-12

Figure 4-4 Allocation of Total Costs to Manage Garbage $\ldots \ldots \ldots \ldots \ldots \ldots$. . . . .

Figure 4-5: Allocation of Total Costs to Manage Recyclables . . . . . . . . . . . 4-19

Figure 4-6: Allocation of Total Costs to Manage Yard Waste . . . . . . . . . . . 4-20

Figure 4-7: Allocation of Total Costs to Manage Non-Recyclable Bulky Waste . . 4 4-22

Figure 4-8: Allocation of Total Costs to Manage HHW . . . . . . . . . 4-23

\section{List of Tables}

Table 3-1: $\quad$ MSW and Other Wastes Collected, Processed, and/or Disposed of in Springfield in FY $1993 \ldots \ldots \ldots \ldots \ldots$. . . . . . . . . . . . . .

Table 3-2: $\quad$ Springfield MRF -- Recovered Material Sold in FY $1993 \ldots \ldots$. . . . . 3-5

Table 3-3: $\quad$ Markets for Recovered Materials Sold in FY $1992 \ldots \ldots \ldots \ldots$. . . . 3-8 


\section{List of Tables (Continued)}

Table 3-4: Collection and Disposition OF HHW $\ldots \ldots \ldots \ldots \ldots \ldots \ldots$

Table 4-1: $\quad$ Springfield FY 1993 Resource Recovery Program Incremental Cost and Effectivenuess . . . . . . . . . . . . . . . 4-5

Table 4-2: $\quad$ FY 1993 Total MSW and Analyzed MSW Tonnages by Component . . . 4-7

Table 4-3 Net Costs for the Springfield IMSWM System (FY 1993) . . . . . . . . . 4-9

Table 4-4: Density of Various Types of Waste Disposed of in the Landfill . . . . . 4-16

Table 4-5: Incremental Cost of the Waste-to-Energy Program . . . . . . . . . . 4-24

Table 4-6: Incremental Cost of the Curbside Recycling Program . . . . . . . 4-26

Table 4-7: Incremental Cost of the Yard Waste Composting Program $\ldots \ldots \ldots$. . . 28

Table 4-8: Incremental Cost of the Office Wastepaper Recycling Program . . . . . 4-30

Table 4-9: Incremental Cost of the White Goods Recycling Program . . . . . . . . 4-32

Table 5-1: Energy Consumption on a Per-Gallon Equivalent Basis . . . . . . . . 5-2

Table 5-2: $\quad$ Energy Consumption to Collect Garbage, Bulky Waste, Office Paper, and Recyclables in Springfield (FY 1993) ............. 5-3

Table 5-3: Vehicles and Equipment Fuel Consumption Data $\ldots \ldots \ldots \ldots \ldots \ldots$. . . . .

Table 5-4: $\quad$ Energy Consumption by Functions $\ldots \ldots \ldots \ldots \ldots \ldots \ldots \ldots$

Table 5-5: Equivalent Gallons for Transporting Recyclables $\ldots \ldots \ldots \ldots \ldots \ldots$

Table 6-1: New Source Performance Standards $\ldots \ldots \ldots \ldots \ldots \ldots \ldots \ldots$

Table 6-2: $\quad$ Pollutants Regulated by the NPDES Permit Program $\ldots \ldots \ldots \ldots \ldots$. $\ldots$

Table 6-3: Maximum Contaminant Levels Promulgated Under the Safe Drinking Water Act . . . . . . . . . . . . . . . . . . . . . . . 6-5

Table 6-4: Implementation Schedule for Waste Disposal Ban $\ldots \ldots \ldots \ldots \ldots \ldots$

Table 6-5: $\quad$ Emissions Limits - Springfield RRF .............. 6-11

Table 6-6: Wastewater Discharge Limitations - Springfield RRF . . . . . . . 6-11 


\section{List of Tables (Continued)}

Table 6-7: Permitting Activity - Springfield RRF $\ldots \ldots \ldots \underline{\text { Page }}$

Table 6-7: $\quad$ Permitting Activity - Springfield RRF $\ldots \ldots \ldots \ldots \ldots \ldots \ldots \ldots$ 6-12

Table 6-8: $\quad$ OSHA Standards and Rules ................... 6-15 


\section{Introduction}

Springfield, Massachusetts ("the City"), is located in Hampden County in the Pioneer Valley of western Massachusetts, as shown in Figures 1-1 and 1-2..$^{\prime}$ The Springfield area was settled in 1635. One of the first English-speaking settlers was William Pynchon, an original patentee of the Massachusetts Bay Colony. Pynchon, a fur trader, purchased land on the east bank of the Connecticut River from the Agawam Indians for "eighteen hoes and knives, twenty coats plus eighteen fathoms of wampum." ${ }^{2}$ He named this land Springfield after his hometown in England. In addition to the Agawam Indians, other tribes who inhabited westem Massachusetts at that time were the Mohawk, Waoronocos, Nonotucks, and Pocumtucks.

The armament industry based in Springfield has played a significant roll in the history of the United States. George Washington established the country's first arsenal in Springfield in 1779. The Springfield musket, manufactured during the Civil War, the Springfield Rifle, invented in 1903, and the M-1 Rifle, manufactured during World War II, were all developed in Springfield. Smith \& Wesson remains one of Springfield's major employers.

Historically, machinery, electrical equipment, and printing have been among the most important industries of the region. As is true of most cities in the Northeast, Springfield has experienced a loss of manufacturing jobs. In 1991 manufacturing accounted for about 28 percent of the nonagricultural employment in the Pioneer Valley. Fabricated metals, electrical equipment, nonelectrical equipment, and paper and printing account for over 45 percent of the manufacturing jobs in the region. The overall number of jobs in the region has increased over the past 20 years due to the growth in non-manufacturing jobs. In 1991 non-manufacturing jobs, particularly in the finance, insurance, real estate, and higher education sectors, accounted for about 72 percent of the non-agricultural jobs in the region. ${ }^{3}$

There are four institutions of higher education located in Springfield: American International College, Springfield College, Springfield Technical Community College, and Western New England College. Springfield is probably best known, however, for the game of basketball, which was invented by Dr. James Naismith in 1891 at the Springfield YMCA, the site of which is now located at Springfield College.

The City of Springfield was incorporated in 1852. It is governed by a mayor and nine City Council members elected at large in nonpartisan elections. Springfield's population grew steadily from 1900 to the early 1960 s, peaking at about 175,000 people. It dropped to a recent low of about 152,000 in 1980 and is currently about $157,0000^{4}$ There were 61,320 housing units in the City in 1990: 25,374 detached one-units; 2,637 attached one-units; 17,663 two- to four-units;

1 The Pioneer Valley consists of Hampden, Hampshire, and Franklin Counties and is the fourth largest metropolitan area in New England.

2 "Welcome to Springfield," the 1994-1995 Official Guide to Springfield and the Pioneer Valley, p. 2.

3 "A Profile for Manufacturing Industries," and "Major Employers of the Pioneer Valley," Massachusetts The Venture Capital, Massachusetts Office of Business Development, Boston, MA.

4 As reported by the U.S. Census, Springfield's 1990 population was 156,983 . The Pioneer Valley Planning Commission projected Springfield's 1992 population to be about 157,210. 
Figure 1-1: Map of the Commonwealth of Massachusetts

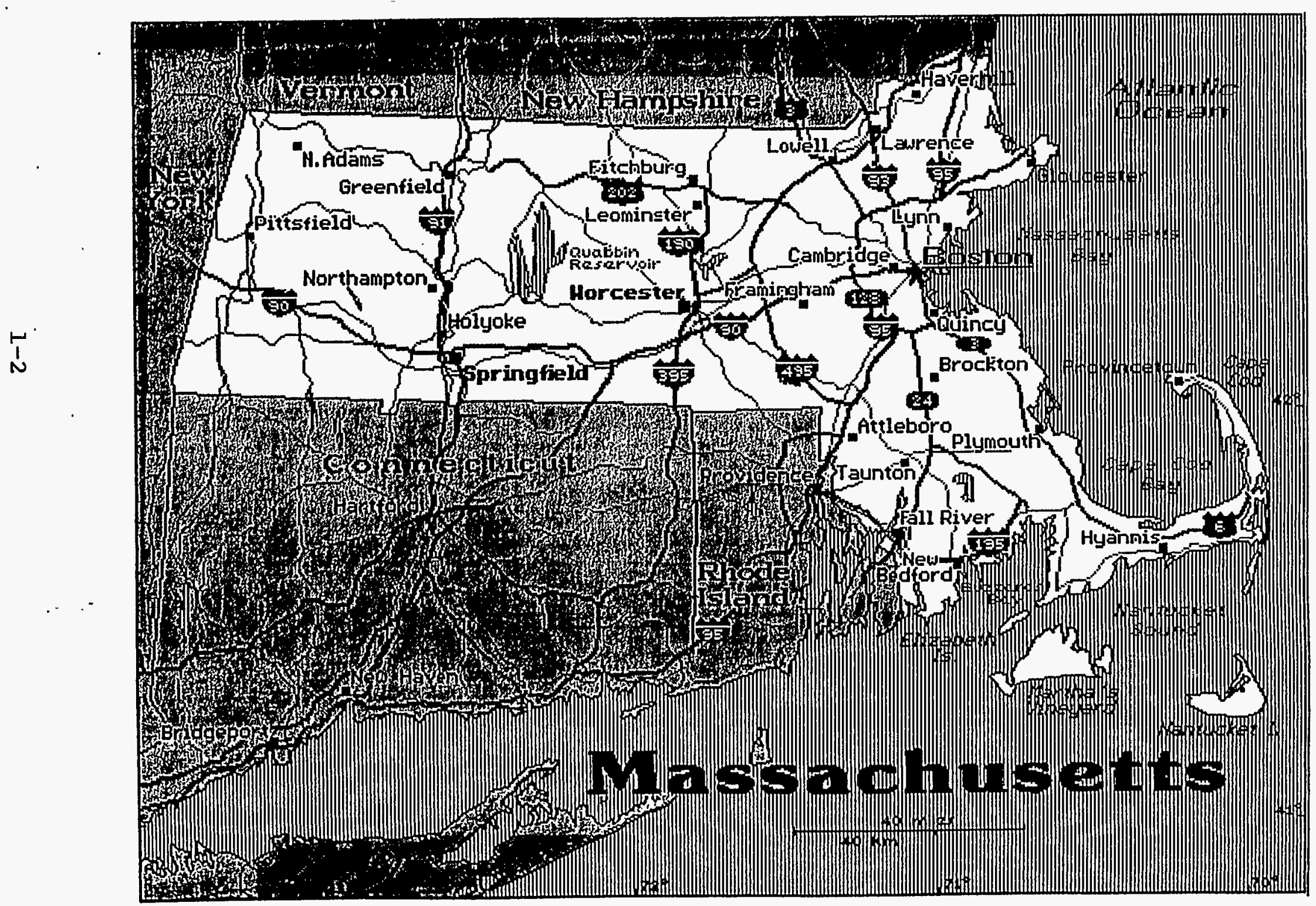


Figure 1-2: Counties of Massachusetts

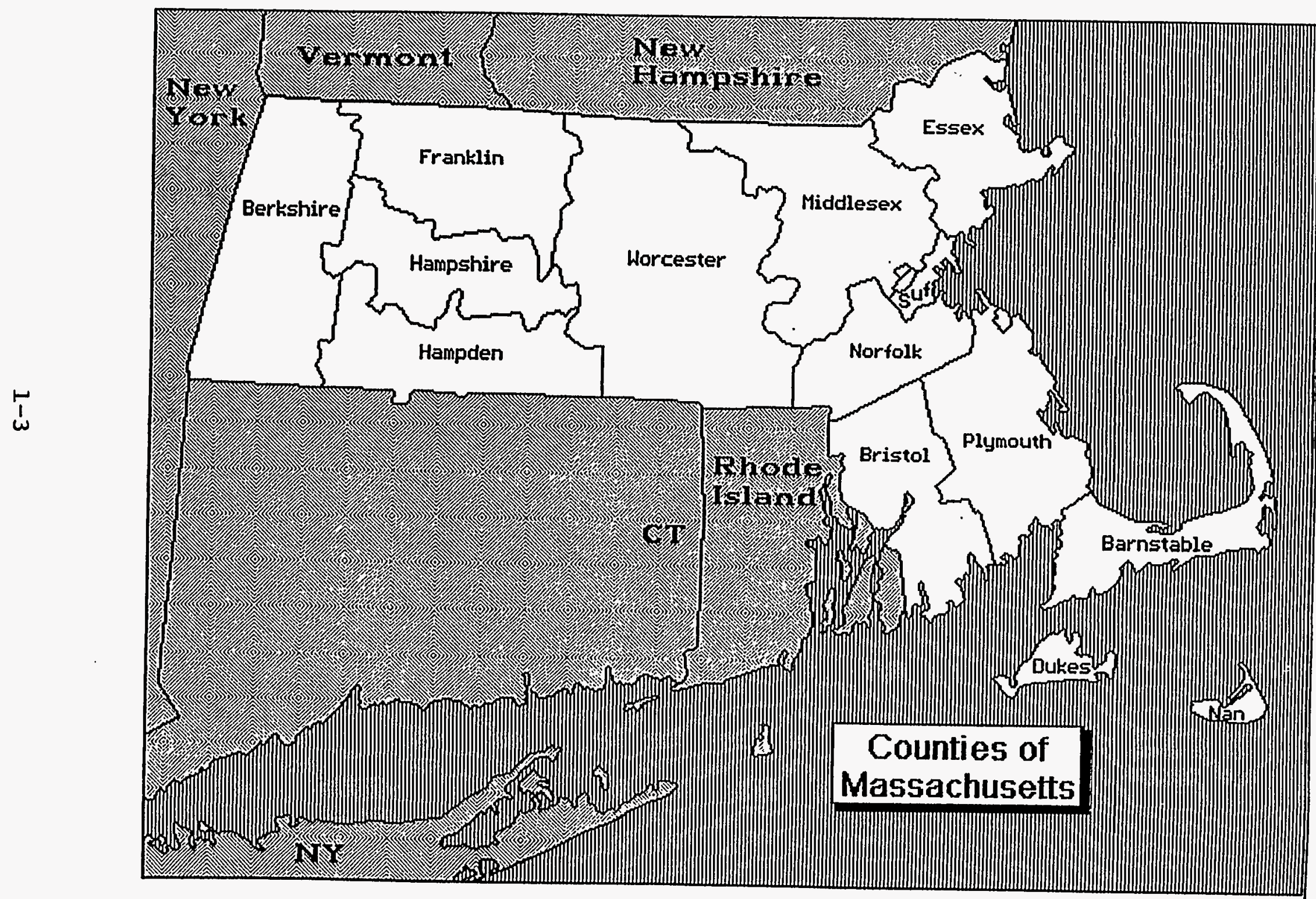


5,094 five- to nine-units; 8,917 10- or more units; and 1,635 mobile homes, trailers, and "other". About 94 percent of these housing units were occupied in $1990 .^{5}$ Springfield encompasses an area of approximately 33.1 square miles (including 1.38 square miles of water), yielding a population density of about 4,740 persons per square mile. Springfield is 8.9 miles wide in an east-west direction and 6.4 miles at its widest point in the north-south direction. Over 640,000 persons reside in the Pioneer Valley, about 500,000 of whom live within a 5- to 15-minute commute to the City.

During fiscal year 1993, which extended from July 1, 1992, through June 30, 1993 (FY 1993), about 61,200 tons of municipal solid waste were managed by the City's Department of Public Works (DPW).

${ }^{5}$ U.S. Bureau of the Census, "Summary Population and Housing Characteristics, Massachusetts," Table B. Structure and Vacancy Characteristics; 1990, p. 59. 


\section{The City's Integrated Municipal Solid Waste Management System}

\subsection{System Overview}

The City's 1993 Integrated Municipal Solid Waste Management (IMSWM) System consisted of the following integrated System components:

- $\quad$ separate collection of garbage, recyclables, yard waste, and bulky wastes by the City;

- a State-owned, privately operated regional materials recovery facility (MRF);

- a privately owned and operated regional waste-to-energy (WTE) facility;

- a City-owned and -operated yard waste composting operation;

- a City office paper recycling program;

- a white goods preparation and storage area;

- a City-sponsored annual household hazardous waste collection day;

- a City-owned, privately operated landfill for the disposal of ash and by-passed waste from the WTE facility, and some other types of wastes; and

- a privately owned and operated landfill for the disposal of bulky wastes.

Municipal solid waste (MSW) is categorized in this report as comprising garbage, yard waste, recyclables, bulky wastes (including white goods), and household hazardous waste (HHW). Figure 2-1 is a graphical representation of these components of MSW. The reader is advised to peruse the Glossary of Terms in Appendix A for a more detailed definition of these and other terms used in this document.

A description of each of the individual components of the City's IMSWM System follows. The locations of the various facilities are shown in Figures 2-2 and 2-3.

\subsection{System Component Descriptions}

\subsubsection{Collection}

The DPW collects garbage once a week, Tuesday through Friday, from all residents living in homes, including mobile homes, with four or fewer dwelling units. The number of dwelling units served in FY 1993 was about 44,500 . The City also collects garbage from City office buildings and approximately 400 small commercial establishments, including some large multi-family 


\section{FIGURE 2-1: MSW: DEFINED CONSTITUENTS}

Municipal Solid Waste

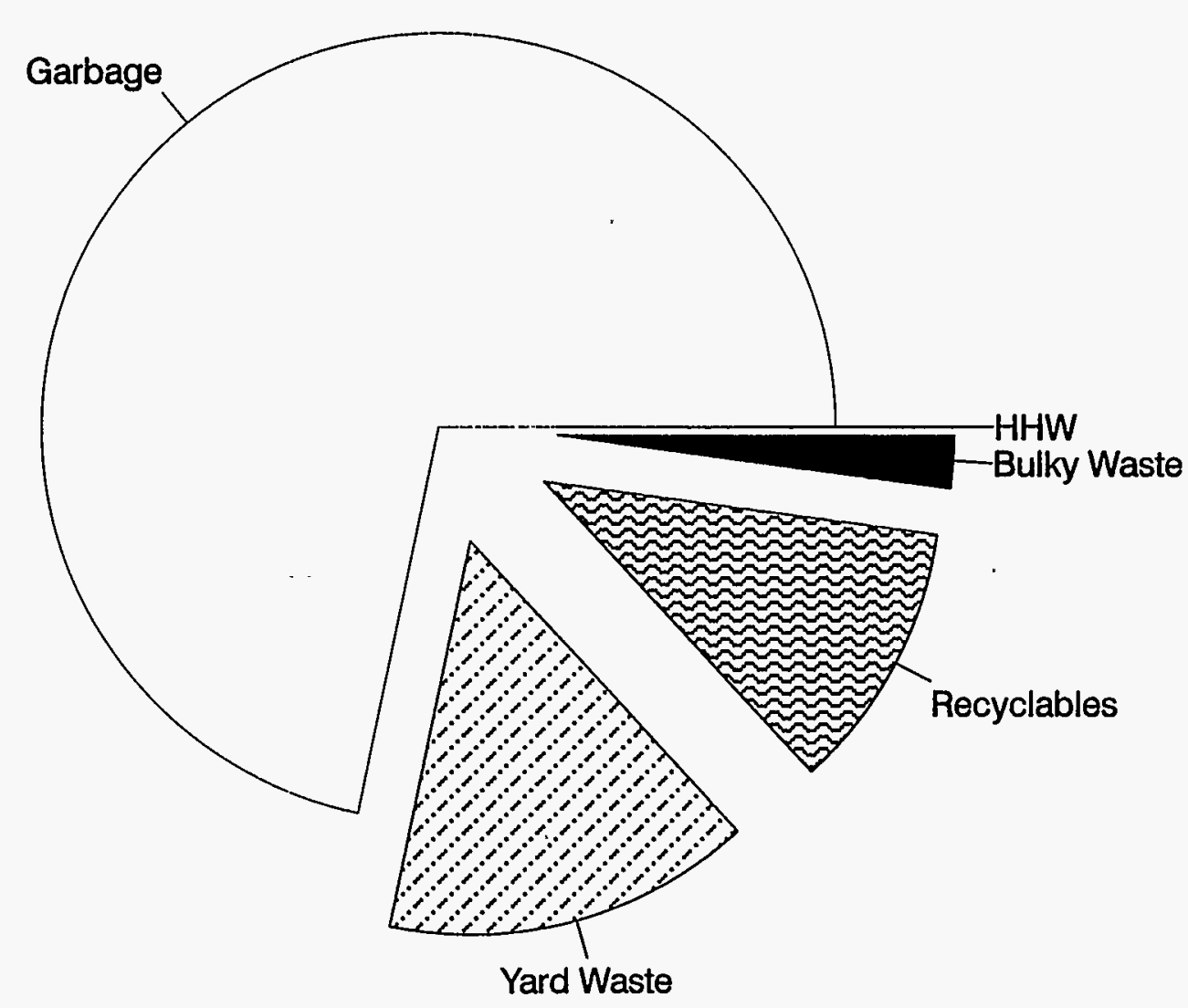


Figure 2-2: Location of MSW Management Facilities in Springfield, Massachusetts

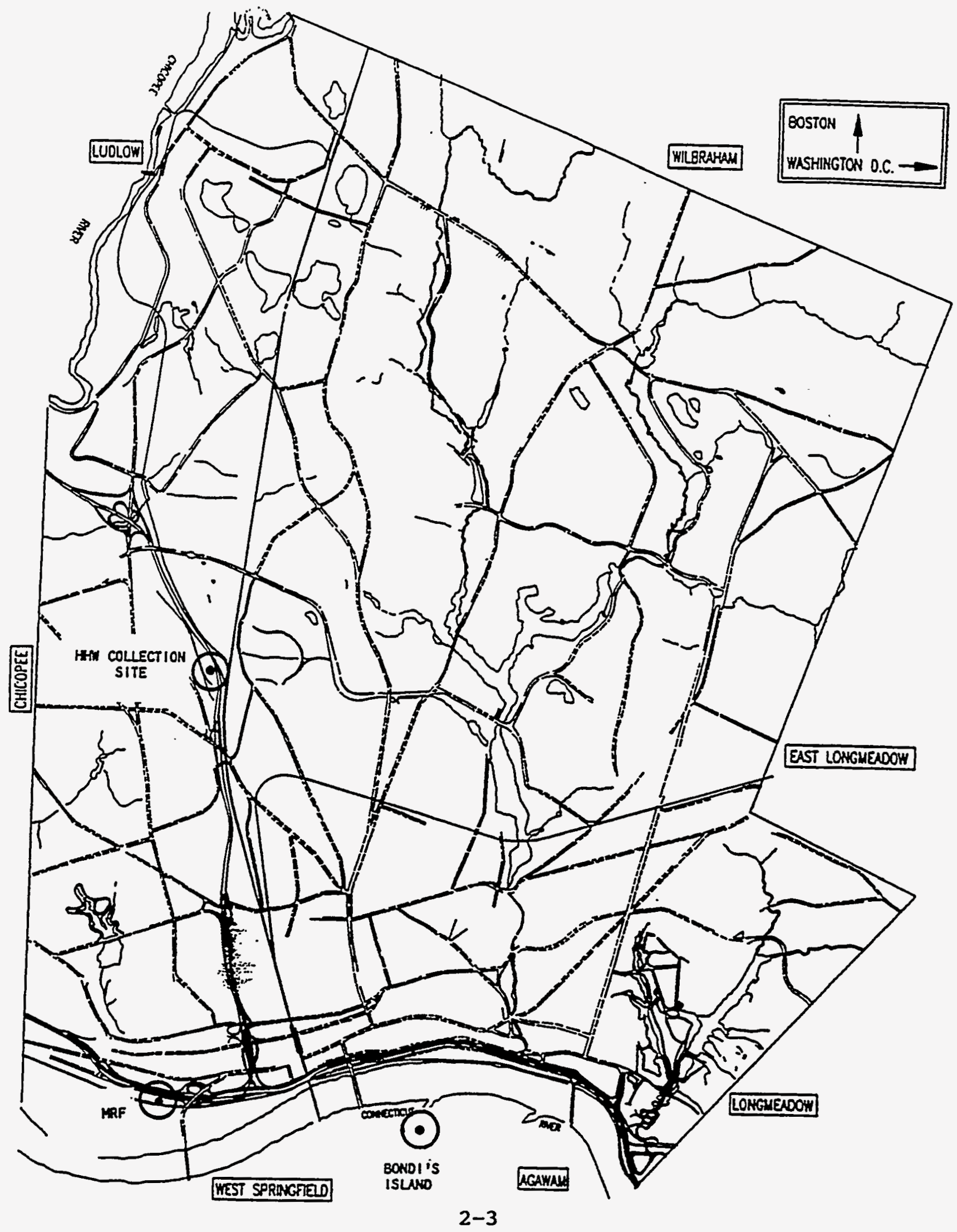




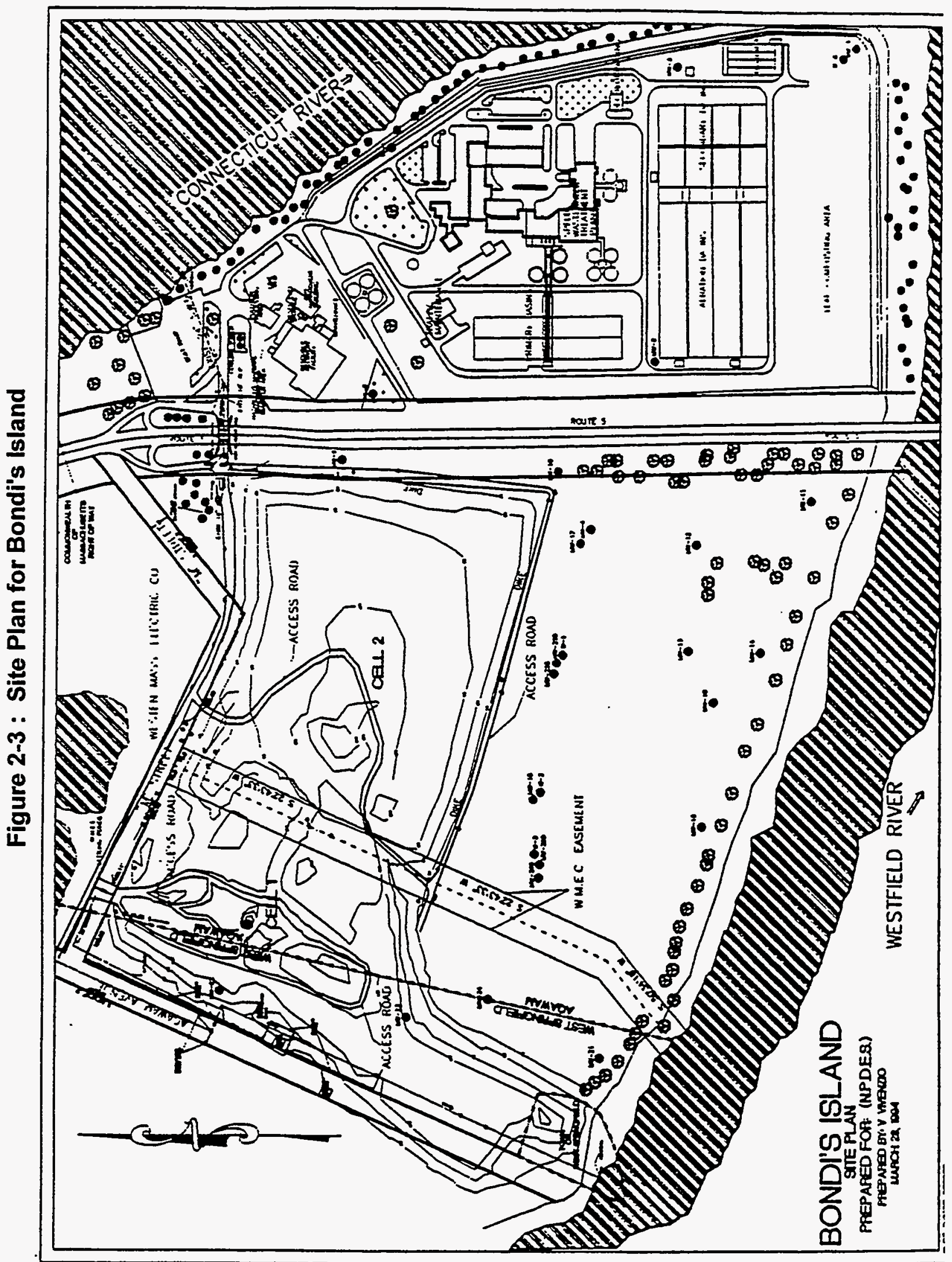


homes. ${ }^{6}$ In FY 1993 the City used a fleet of 14 31-cubic-yard rear-loading packer trucks for the collection of garbage (two were spare vehicles). Each truck is manned by a driver and two workers.

The City passed an ordinance in June 1986 making residential recycling mandatory for those households that are offered curbside collection by the City. ${ }^{7,8}$ In FY 1993 individuals living in homes with three or fewer dwelling units, exclusive of mobile homes, were offered curbside recycling services. Materials placed at the curb become the property of the City, and any scavengers are subject to a fine of up to $\$ 300$ and may also have to make restitution to the City for the value of the materials taken.

In FY 1993 approximately 41,000 households participated in the curbside recycling program. ${ }^{9}$ Recyclables are placed in 12-gallon "Blue Boxes" supplied by the City and are collected from each residence participating in the program once every other week on the same day that garbage is collected. In FY 1993 the City used a fleet of eight 31-cubic-yard collection vehicles. Each vehicle has two adjustable compartments, one for paper and the other for commingled containers. Each vehicle is manned by a single person.

In April 1991 the City, in conjunction with the other nine communities that use the WTE facility, began the curbside collection of button batteries used in such items as cameras, calculators; hearing aids, and watches. No other types or sizes of batteries are collected. Residents place their button batteries in an orange plastic bag provided by the City and then place that in their recycling Blue Box. The recycling truck operator takes the bag and leaves an empty one for future use. The batteries are dropped off at the MRF, where they are weighed and temporarily stored prior to being picked up by WTE facility personnel.

The City passed an ordinance in October 1988 making certain compostable leaves and yard waste separation mandatory. ${ }^{10.11}$ Prior to April 1993, individuals living in homes with four or fewer dwelling units, inclusive of mobile homes (i.e., the same households that receive garbage

${ }^{6}$ Most of the garbage generated by residents living in multi-family homes with 5 or more dwelling units and other commercial and business establishments are served by private collection companies. This MSW is not managed by the City and, therefore, is not included in this study.

7 "Mandatory Recycling," Revised Ordinances of the City of Springfield, 1963, as amended, Chapter 9, Section 4, Subsection 7.16.040, June 19, 1986.

8 Violators are subject to a fine that is not to exceed $\$ 50$.

9 About 3,500 households (9,200 people) that receive garbage collection services from the City do not receive recyclables collection services. Including the approximately 20,000 multi-family households that do not receive garbage collection services from the City, about 33 percent of Springfield's population does not have an opportunity to recycle. (Source: DPW, "Springfield Facts.")

10 "Mandatory Yard and Leaf Waste Composting," Revised Ordinances of the City of Springfield, Title 7, Chapter 7.16, Subsection 7.16.041.

$"$ Violators are subject to a fine that is not to exceed $\$ 50$. 
collection from the City), were offered, during the fall months, separate curbside collection of leaves. (Other yard waste was collected as garbage.) After April 1993, the City began separate collection of all types of yard waste. ${ }^{12}$ Materials placed at the curb becomes the property of the City, and any scavengers are subject to a fine of up to $\$ 100$.

Residents must place all yard waste in either paper leaf bags or barrels. Yard waste cannot be placed in plastic bags. The leaf bags "shall be a Sanitary Kraft Paper Sack or equal of thirty (30) gallon capacity, two (2) ply fifty (50) pound wet strength with decomposing glue and reinforced self-supporting square bottom closure."13 Special leaf collection days, on Mondays and Saturdays, were run from mid-October through mid-December 1992. From April 1993 through June 1993, the City collected yard waste once a week, Tuesday through Friday, from all residents who received garbage collection services. ${ }^{14}$ The yard waste was collected, on an overtime basis, in the 31-cubic-yard packer trucks used for garbage collection. Each truck has a three-person crew. A yard waste drop-off site is also maintained during the fall months at the City's landfill for residents of Springfield and Agawam.

White goods and other bulky wastes are collected upon call by residents of the City. The City used two bulk vehicles, each equipped with a hydraulic lift. Two-person crews are used to collect bulky wastes. One of the litter collection vehicles is used once a week to pick up newspapers, magazines, catalogues, kraft paper bags, white paper, colored paper, manila file folders, computer paper, phone books, and clasp envelopes from ten City office buildings.

\subsubsection{Materials Recovery Facility}

The regional MRF is located in Springfield. Its building is owned by the Commonwealth of Massachusetts, acting through the Massachusetts Department of Environmental Protection (DEP, formerly the Department of Environmental Quality Engineering), while the equipment used in the MRF is owned by the operator, Resource Recovery Systems, Inc. (RRS). The Facility is being operated by RRS pursuant to a five-year operating agreement with the Commonwealth. ${ }^{15}$

The MRF began operations in January 1990 and services over 90 communities in and around the Pioneer Valley. The Commonwealth pays all of the capital and operation and maintenance (O\&M) costs for the MRF, thus the users, including the City of Springfield, can deposit

${ }^{12}$ In 1987, the Commonwealth passed the Solid Waste Act, which imposed bans on the landfilling and combustion of certain components of the solid waste stream, such as lead batteries, tires, and yard waste. The ban on leaves became effective in December 1991 and on other yard waste in December 1992. This ban did not affect the City until April 1993, i.e., the spring growing season, when it began separate collection of yard wastes.

13 "Mandatory Yard and Leaf Waste Composting Ordinance," p. 1.

14 Following the end of FY93, the City instituted yard waste collection every other week from April through December. Collection occurs on the same day that recyclables are collected.

15 "Contract for the Springfield Materials Recovery Facility Between the Commonwealth of Massachusetts Acting Through the Department of Environmental Quality Engineering and Resource Recovery Systems, Inc.," March 1989. 
recyclables at no cost. Each community has a contract with the DEP which stipulates that the community will adopt and enforce a mandatory recycling program, collect and transport the recyclables to the MRF, and participate in the Commonwealth's promotional and public education programs.

The operator is obligated to process up to 240 tons of recyclables per day. Commingled containers (i.e., glass, ferrous metals, aluminum, PET, and HDPE) and mixed paper (e.g., newspaper, corrugated, cartons, magazines, phone books) are processed in separate lines. . Materials can be shipped from the facility by either truck or rail. A flow diagram of the MRF is provided in Figure 2-4.

When entering the site, each collection vehicle is weighed at the truck scale. After this initial weighing the vehicle proceeds to the paper receiving area and unloads the paper. The truck returns to the scale to be reweighed and then proceeds to the bottle and can receiving area and dumps its remaining, commingled container load. In this way an accurate account of the tonnage of paper and commingled containers delivered by each customer is obtained. Paper represents about 68 percent, by weight, of the material delivered to the MRF.

The paper deposited in the paper receiving area, i.e., on the tipping floor, is pushed onto an inclined conveyor by a small front-end loader and is conveyed up to the elevated paper sorting area. The paper is handsorted into various grades of paper depending on the quality of the incoming loads and market demand for specific grades. If market conditions warrant, the line can be slowed down to obtain a higher grade of paper. In FY 1993, \#6 news, \#7 news, \#8 news, corrugated, carton, and a special mixed paper were recovered for sale. Positive sorts of specified types of paper and any unacceptable material are placed into appropriate chutes leading to storage areas below the sorting area. Newspaper remains on the conveyor and is deposited into a holding bin at the end of the conveyor. The paper is stored until it is baled.

The commingled containers deposited in the bottle and can receiving area (i.e., tipping floor) are first inspected by the front-end loader operator for large and/or unprocessible items. Acceptable material is pushed onto an inclined conveyor by a small front-end loader and is conveyed up to the elevated container sorting area. Ferrous metals are mechanically separated prior to the material reaching the handsorting area. The separated metals are flatted and deposited in storage bins. Aluminum, glass, and plastics are also handsorted. The color-sorted and mixed glass are then crushed, screened, and stockpiled in separate bins. Plastics are stored for later baling. Materials not handpicked are deposited in residue bins for disposal at a landfill. In FY 1993 the flint, green, amber, and mixed cullet; tin cans, scrap steel, aluminum cans, aluminum foil, and aluminum deposit; and PET deposit, clear HDPE, color HDPE, \#4 plastic, and other plastic were recovered for sale. ${ }^{16}$

\subsubsection{Waste-to-Energy Facility}

The 360-ton-per-day (TPD) regional waste-to-energy (WTE) facility, located in Agawam adjacent

16 Massachusetts is a bottle bill state. A 5-cent deposit is charged on all soft drink and beer glass, plastic, and metal bottles and cans. "Aluminum deposit" and "PET deposit" are containers for which the 5-cent deposit can be recovered. 
Figure 2-4: MRF Flow Diagram - Springfield, Massachusetts

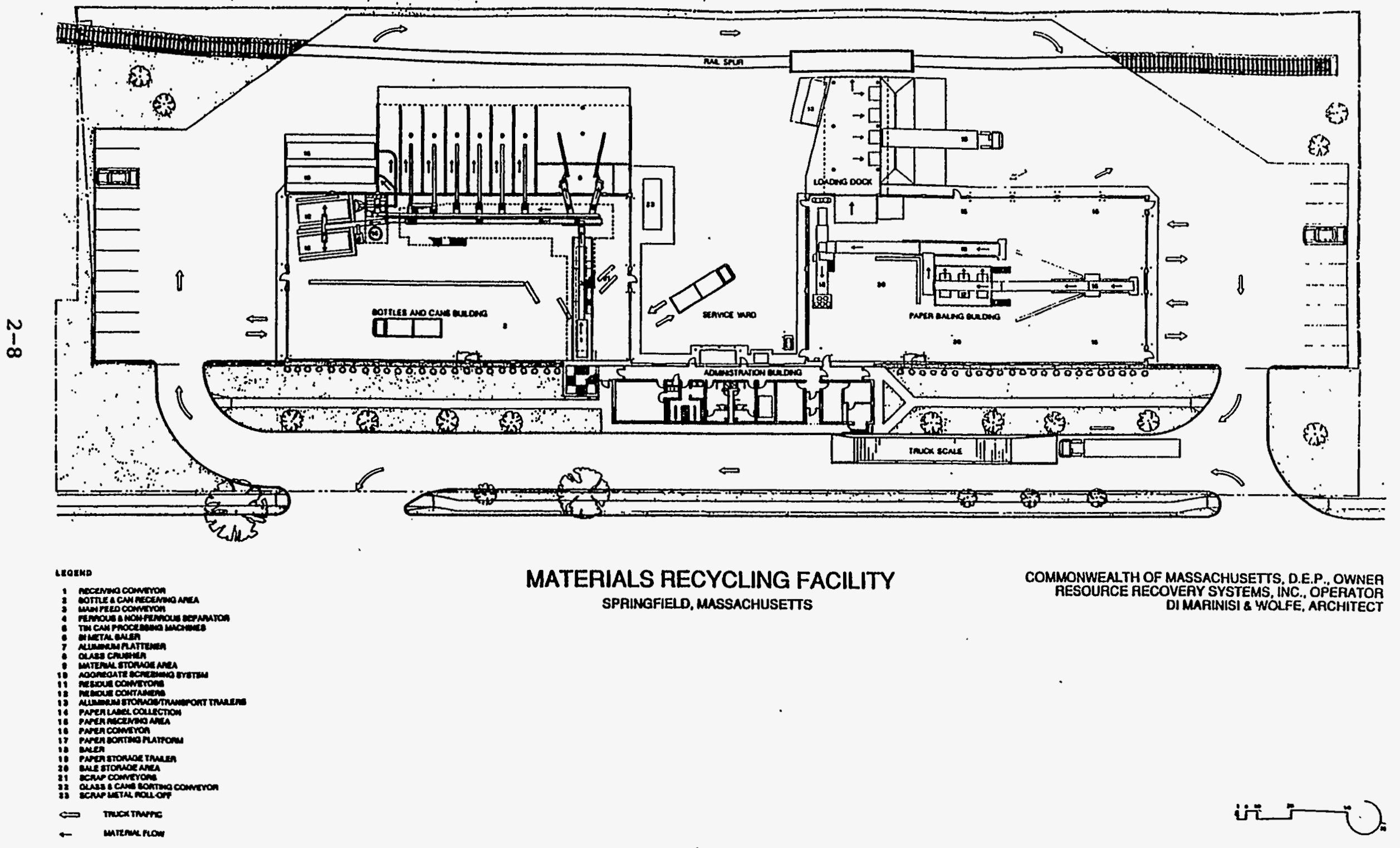


to Springfield's landfill and wastewater treatment complex (known as Bondi's Island), is owned by a subsidiary of the Fluor Corporation. The facility was developed by Vicon Recovery Systems and employs the Enercon technology for the combustion of MSW. Fluor Daniel designed and constructed the facility and was responsible for performance testing. Springfield Resource Recovery Inc., a subsidiary of Fluor Corporation, operates the facility.

Springfield is one of the ten communities in the Pioneer Valley that have a 25-year contract for the use of the WTE facility. Commercial MSW is also accepted at the facility on a spot market basis. Full-scale commercial operation began on August 1, 1988.

The WTE facility generates both electricity and steam for sale. Electricity is sold to the Western Massachusetts Electric Company, and steam is sold to the Springfield Regional Wastewater Treatment Facility on Bondi's Island. Of the steam sold, about 16.8 percent was generated through the combustion of MSW; the balance was generated using an oil-fired package boiler.

After each delivery vehicle is weighed, the truck operator dumps its load either onto the tipping floor or into the storage pit. Unprocessible waste, such as bulky items, are set aside in roll-off containers for later disposal at a landfill. Some metals are also removed from the incoming MSW prior to combustion.

The three 120-TPD multiple-stepped, fixed-grate furnaces are fed by front-end loaders. ${ }^{17,18}$ The MSW is moved through the hearths by a hydraulic, water-cooled ram. The primary chamber consists of six progressively lower refractory-lined hearths. The MSW tumbles as it falls from one section, or step, to another. Combustion is completed in a secondary chamber in which combustion temperatures are controlled. Flue gas recirculation is used to assist in controlling combustion and boiler entrance temperatures and to reduce nitrogen oxide emissions. Each combustion train is also equipped with an oil-fired burner for use during startup and shutdown, and if necessary, to maintain proper combustion temperatures in the furnaces. The $650 \mathrm{psig}$, $750^{\circ} \mathrm{F}$ steam is produced by the three waste-heat boilers. The three boilers share a common 9.4MW condensing extraction turbine, generator, cooling tower, and water treatment plant. Each combustion train is equipped with a dry lime injection system for the control of acid gases and a pulse-jet-cleaned baghouse for the control of particulate matter. The flue gases are then released to the atmosphere through a common 175-foot stack.

Bottom and fly ash are combined, quenched, and discharged by conveyor to the ash building for drying. Subsequently, the ash is delivered by truck to the City's Bondi's Island ash landfill for disposal. There is no post-combustion material recovery at the WTE facility.

Button batteries collected by the City are picked up by WTE personnel and sent to a reprocessor for recovery of mercury and other materials from the batteries. Another objective of the button battery program is to reduce the amount of mercury in the WTE facility flue gas and ash.

17 The units are rated using an MSW higher heating value of 4,500 Btus per pound.

18 On June 17, 1993, the DEP approved an increase in total daily capacity for all three units from 360 TPD to 408 TPD. 
Figure 2-5 provides a flow diagram of the WTE facility.

\subsubsection{Yard Waste Composting Operation}

Since 1987 the City has operated an eight-acre site for composting its leaf and yard waste at the future expansion area of the Springfield Regional Wastewater Treatment Plant at Bondi's Island. The top soil at the site was removed and replaced with 12 inches of gravel. Several one-foot wide, two- to three-feet deep drainage trenches surround the site. The trenches are lined with geofabric, laid with a four-inch perforated PVC pipe, and filled with crushed stone. The PVC pipes are tied into the existing site drainage, which leads back to the wastewater treatment plant.

Prior to April 1993 leaves delivered from both Springfield and Agawam were unloaded into designated lines, or windrows. Because the leaves are placed in biodegradable paper bags or barrels there is no need for any debagging operation. ${ }^{19}$ After April 1993, when other yard waste was included in the program, non-leaf yard waste, which then contained woody prunings and brush, was processed through a yard waste grinder. The grinder. is mounted to a trailer, allowing the ground yard waste to be placed directly into windrows.

Each windrow is initially about 275 feet long, 18 feet wide, and eight feet high. The windrows are turned and aerated regularly using a SCARAB (Model 18). Initially a windrow is turned about three times a week. As the compost material cures, the frequency of the turning time is reduced to less than once a week. To maintain efficient use of the available land and the use of the SCARAB, a bucket loader is used to combine windrows after they have been reduced by at least 50 percent. It takes about six to seven months to complete the composting process.

\subsubsection{Office Paper Recycling Program}

The City's office paper recycling program began in December 1990. The Department of Public Works (DPW) distributed 12-gallon recycling Blue Boxes to each City department and 96-gallon wheeled recycling containers to each building. Clean, used office and computer paper are deposited in the Blue Boxes. The building custodians transfer the collected paper from the Blue Boxes to the 96-gallon containers. Every week the 96-gallon containers are wheeled to the curb for collection by the DPW. This office paper is delivered to the MRF for processing.

\subsubsection{White Goods Preparation and Storage}

The City collects white goods and other metals from residents by appointment. The white goods are delivered to the City's landfill at Bondi's Island, where the chlorofluorocarbons (CFCs) are extracted from certain appliances for recycling. The white goods and metals are stored until at least 75 tons have accumulated. The City then notifies a contractor to pick up the material. The contractor brings a portable bailer to the site, bales the white goods and hauls the material away.

19 The high labor incurred by the City during its 1987 pilot program for debagging plastic bags led to the requirement that leaves and yard waste be placed in biodegradable paper bags or barrels. 
Figure 2-5: Flow Diagram of the Waste-to-Energy Facility

SRR

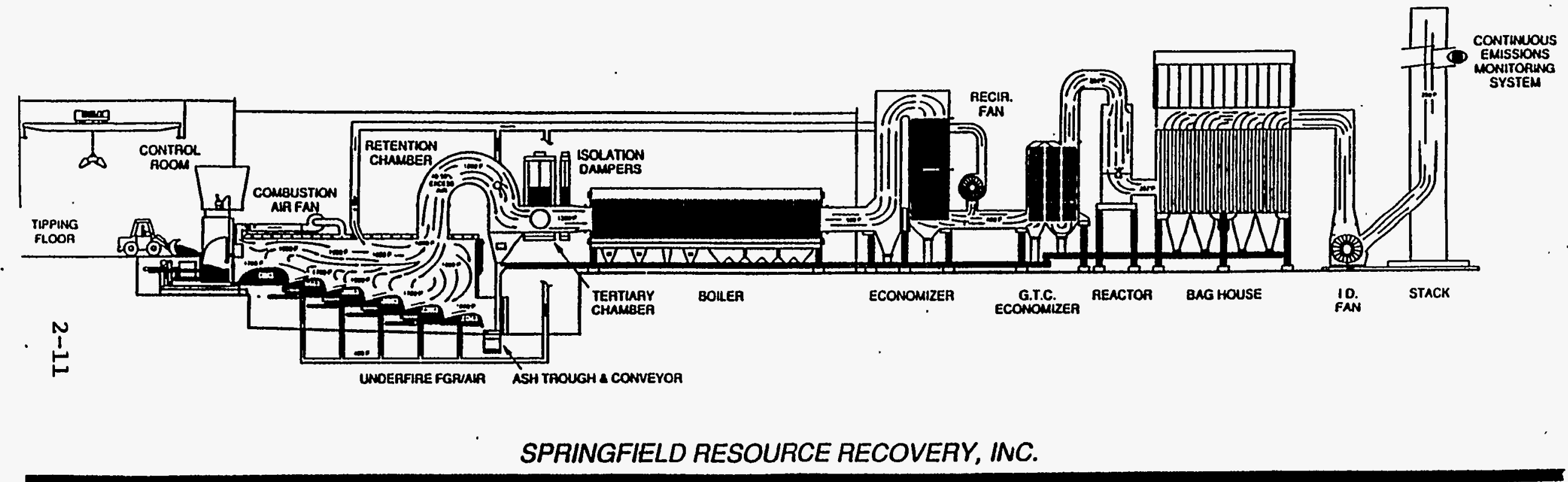

Agawam, Massachusetts 


\subsubsection{Household Hazardous Waste Collection Day}

The City has been sponsoring HHW collection since 1988. In FY 1993 an HHW collection day was held on Saturday, May 1, 1993. The site for the HHW program was donated by Milestone, Inc., an industrial firm located in Springfield. The program was sponsored by the City, but carried out by 50 neighborhood, civic group, industrial, and municipal volunteers. The City hired The Green Paint Company to recycle both latex and solvent-based paints, and Clean Harbors of Natick, Inc. to manifest, haul, recycle, treat, incinerate, and/or dispose of in a hazardous waste landfill other HHW materials that were collected.

For the sake of convenience, residents were allowed to make appointments for dropping off their HHW. Two hundred and sixty-six (266) of the 356 residents who made appointments actually dropped off $\mathrm{HHW}$. Another 80 residents who did not have appointments were also served. Based on an exit poll conducted by the City, about 19 percent of respondents indicated that they brought HHW for their neighbors or relatives; thus, the City estimated that 500 households participated in the program. ${ }^{20}$

During the HHW day a swap table was set up where residents could trade usable products.

\subsubsection{Landfills}

The Bondi's Island Sanitary Landfill, owned by the City, is located in the neighboring communities of Agawam and West Springfield. Cells 1 and 2 contain 20 and 30 acres, respectively, and are located in Agawam. Cell 3, located in West Springfield, comprises 18 acres. Cell 2 is closed and covered and is being reserved for future vertical expansion as an ash monofill, and cell 3 is closed with no plans for its future expansion. Only cell 1 is currently active.

Cell 1 is divided into 10 subcells. The subcells have either a double liner system, consisting of a primary, 60-mil, high-density, polyethylene (HDPE) or a 30-mil, polyvinylchloride (PVC) liner $^{21}$ installed over a two- to four-foot thick, low permeability, clay secondary liner. One foot of sand was placed over the liner for protection and to facilitate leachate collection.

The leachate collection system consists of approximately 20,000 linear feet of pipe and four pump stations. A 1.3-million-gallon leachate pretreatment facility was constructed as part of the vertical expansion of Cell 1. The collection and pretreatment facilities were designed to collect and pretreat contaminated groundwater resulting from the original unlined landfill. Final treatment of the leachate is performed at the wastewater treatment facility. The landfill also has a landfill gas control system.

The landfill is operated by Resource Control, Inc. (RCI) under contract to the City. RCI is responsible for the proper disposal of ash and bypassed MSW from the WTE facility, sludge

${ }^{20}$ Letter from Michael Pattavina, Project Director, Springfield DPW, to the Union News, May 17, 1993.

${ }^{21}$ The PVC liners are used for subcells that accept garbage, while HDPE liners are used for the cells that accept ash. 
compost from the City's sewer sludge composting facility, grit and screening from the wastewater treatment facility, catch basin and sewer cleanings, and street sweepings delivered to the landfill for disposal. Separate subcells are used for the disposal of ash and the other wastes disposed of in Cell 1. RCI also maintains the leachate collection pretreatment system and performs environmental testing and monitoring of the site.

Closure and post-closure monitoring plans for Cell 1 have been submitted and approved by the DEP. The City Council has authorized a bond for $\$ 5,000,000$ to cover closure costs.

To conserve space, bulky wastes are not accepted at the Bondi's Island landfill. In FY 1993, nonrecyclable bulky wastes were disposed of at a privately owned and operated landfill, located in the city of Chicopee. 



\section{MSW Collected, Processed, and/or Disposed of by Springfield in Fiscal Year 1993}

A total of approximately 61,200 tons of MSW was collected, processed, or disposed of by the City in FY 1993. Of this amount, 73.0 percent was garbage, 13.0 percent was yard waste, 11.6 percent was recyclables, 2.2 percent was bulky waste (including white goods), and less than 0.1 percent was HHW. Table 3-1 summarizes the tonnage collected, processed, and/or disposed of by the City during FY 1993. This tonnage does not include MSW collected by private firms from residential buildings with five or more dwelling units or from commercial, institutional, or business establishments. An MSW flow and resource recovery diagram of this waste stream is depicted in Figure 3-1.

In the following Sections 3.1 through 3.4, the types and quantities of MSW collected, processed, and/or disposed of by the City during FY 1993 are presented in more detail.

\subsection{Garbage Collection, Combustion, and Disposal}

A total of 44,707 tons of garbage was collected by the City from residences with four or fewer dwelling units (including mobile homes), litter barrels located throughout the City, City office buildings, and approximately 400 small commercial establishments. All of this tonnage was delivered to the WTE facility.

Data on the quantity of MSW collected within the City by private firms from multi-family residential (i.e., five or more dwelling units) or commercial, institutional, and business establishments is not available. ${ }^{22}$ Most of this privately collected MSW was disposed of at area landfills and some was delivered to the WTE on a spot basis.

In FY 1993 the City's DPW delivered 38.6 percent of the 115,916 tons of MSW received at the WTE facility. About 58.9 tons of the MSW (primarily metals) delivered to the WTE facility were recovered prior to combustion, for recycling. Assuming that the composition of the MSW from all users of the WTE is similar, about 23 tons (i.e., 38.6 percent of 58.9) of this recovered material can be attributed to the City. The WTE facility generated about 38,376 tons of ash, about 14,810 tons (i.e., 38.6 percent of 38,376 ) of which can be attributed to the City. ${ }^{23}$

\subsection{Yard Waste Collection, Processing, and Compost Marketing}

The City collected 6,814 tons of yard waste in FY 1993 from residents of Springfield. ${ }^{24}$ Of this amount, 3,878 tons (or 57 percent) were leaves and the remaining 2,936 tons were other yard

22 DPW, Fax from M. Triggs to A. Cohen, May 31, 1994.

${ }^{23}$ About 72 tons of commercial MSW delivered to the WTE facility was rejected or bypassed. Since none of this tonnage was delivered to the WTE facility by the City or disposed of at the Bondi's Island landfill, it is not included in this study.

${ }^{24}$ This yard waste was collected from residences with 4 or fewer dwelling units. 
Table 3-1: MSW Collected, Processes, and/or

Disposed of in Springfield in FY 1993 (a)

\begin{tabular}{|c|c|c|}
\hline Waste Type & Percent & Tons \\
\hline \multicolumn{3}{|l|}{ GARBAGE } \\
\hline City Collected to WTE & 73.0 & 44,707 \\
\hline \multicolumn{3}{|l|}{ YARD WASTE } \\
\hline City Collected to Compost Site & 11.1 & 6,814 \\
\hline Street Sweeper & 0.6 & 337 \\
\hline Self Haul to Compost Site & 0.6 & 364 \\
\hline Agawam & 1.0 & 607 \\
\hline Subtotal Yard Waste & 13.3 & 8,122 \\
\hline \multicolumn{3}{|l|}{ RECYCLABLES } \\
\hline City Collected to MRF & 11.5 & 7,048 \\
\hline Button Batteries (b) & 0.0 & 0 \\
\hline Office Paper & 0.0 & 22 \\
\hline Subtotal Recyclables & 11.6 & 7,070 \\
\hline \multicolumn{3}{|l|}{ BULKY WASTES } \\
\hline White Goods & 0.8 & 509 \\
\hline Others & 1.3 & 807 \\
\hline Subtotal Bulky Waste & 2.2 & 1,316 \\
\hline HOUSEHOLD HAZARDOUS WASTE & 0.0 & 15 \\
\hline TOTALS & 100.0 & 61,230 \\
\hline
\end{tabular}

SOURCE: DPW, "Solid Waste Management Plan," March 1994.

NOTES:

(a) This table provides data on wastes that are managed by the City of Springfield. As sush this table does not include the waste generated or recycled by commericial, institutional, and business establishments. Therefore, the data in this table does not provide a complete account of waste generation and recycling activities in Springfield.

(b) Springfield Resource Recovery, Inc. indicated that 1,282.7 grams (about 2.8 pounds) of button batteries were collected in FY93 from all the communities using the WTE facility. 
Figure 3-1: MSW Flow and Resource Recovery Diagram - Springfield, MA (FY 1993)

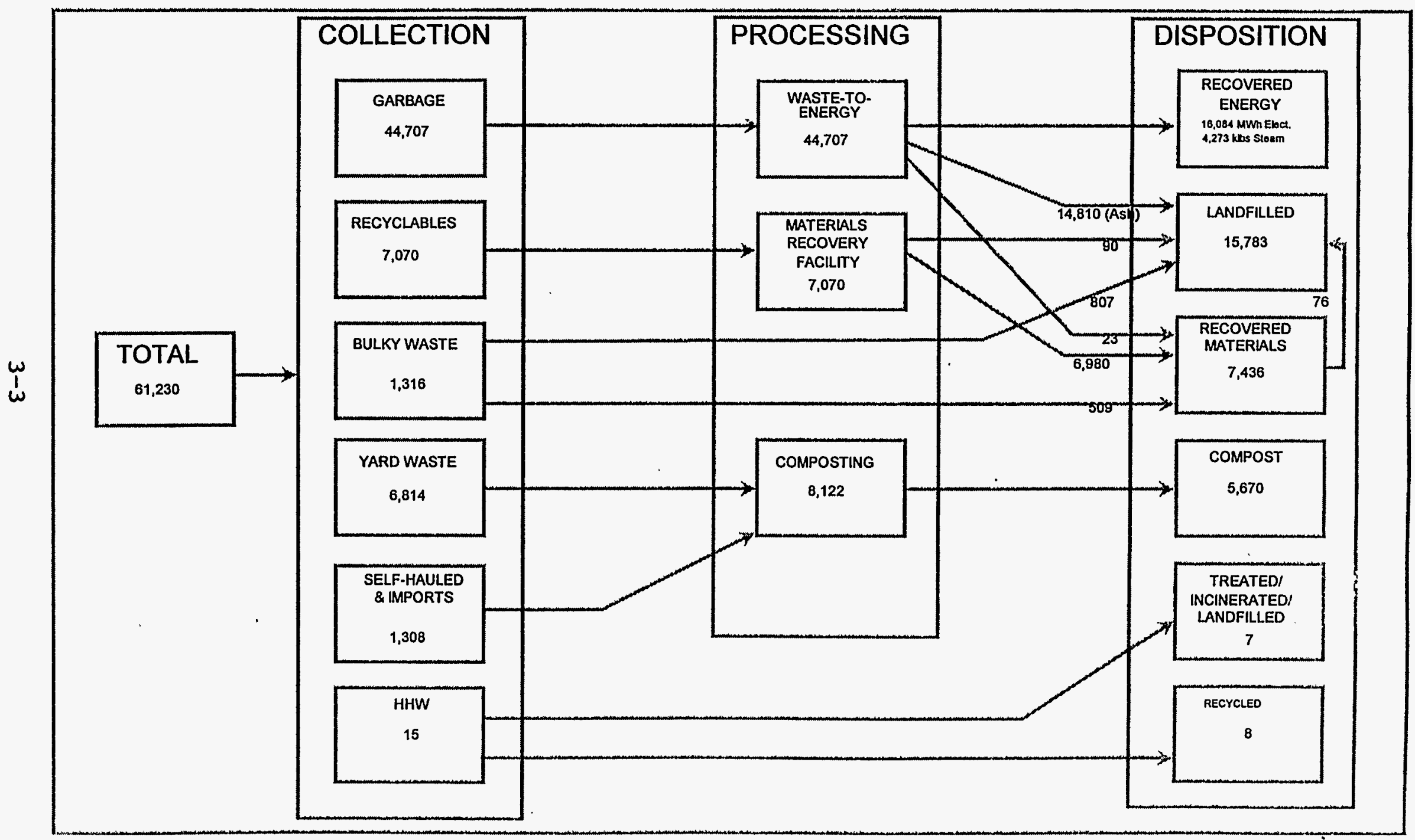


wastes, such as grass, garden waste, weeds, pruning, and brush. ${ }^{25}$ All of this tonnage was delivered to the City's yard waste composting site. In addition, 364 tons of leaves were delivered by Springfield residents to the City's landfill for transfer to the composting site, and 337 tons of leaves were swept from City streets. Pursuant to an Intermunicipal Agreement between Springfield and the City of Agawam, an additional 607 tons of leaves were accepted and processed from residents of Agawam. ${ }^{26}$ In total, 8,122 tons of yard waste were processed by the City in FY 1993: 5,186 tons of leaves and 2,936 tons of other yard wastes. No commercial yard waste was accepted for composting by the City.

From this yard waste the City produced about 5,670 tons of compost. About 10 percent was given away for use by residents, 35 percent was used for municipal projects, and the balance was put out for bid. The City has used the compost to extend its loam stockpile, as cover at the landfill, for Park District use, and for rebuilding City soccer fields. The compost put out for bid was purchased by Ray Haluch, Inc., for $\$ 1.21$ per ton. This compost was mixed with top soil and sold as blended top soil.

\subsection{Recyclables Collection, Processing, and Marketing}

The City collected approximately 7,070 tons of recyclables from two different programs: the curbside collection program, which included the collection of button batteries, and the office paper recycling program. ${ }^{27}$

In FY 1993 the City collected 7,048 tons of recyclables from residents living in households with three or fewer dwelling units, excluding mobile homes. Of this amount, 5,057 tons (or 72 percent) were paper and 1,991 tons (or 28 percent) were commingled containers. All of these recyclables were delivered to the MRF for processing. The City also collected 22 tons of office paper from City buildings. This paper was delivered to the MRF for processing.

The MRF accepts recyclables collected from residents living in over 90 communities in the Pioneer Valley. In total, about 44,100 tons of recyclables were delivered to the MRF in FY 1993; thus, the City accounted for about 16 percent of the materials delivered to the MRF in FY 1993. In FY 1993 about 42,500 tons of recovered materials were sold, 560 were disposed of as residue, and 1,040 were inventoried. Table 3-2 shows the types and quantities of materials sold in FY

${ }^{25}$ On April 1, 1993, the City began to collect all yard waste for composting. Prior to then the City only collected leaves for composting.

26 The City is planning to move the composting operation to a 13.5 -acre site on a closed portion of the City's landfill and accept yard waste from 12 or more additional communities in the Pioneer Valley. See City of Springfield, "1992 Yard Waste Processing Equipment Grant Application to the Commonwealth of Massachusetts," February 11, 1992.

27 Massachusetts is a "bottle bill" state. A 5-cent deposit is charged on all soft drink and beer glass, plastic, and metal bottles and cans. Because this statewide program is not a part of Springfield's IMSWM System, the recycling programs discussed and the tonnages of recyclables presented in this section do not include the recycling results from the Commonwealth's deposit program. However, the cost and effectiveness of the curbside recycling program presented in this report are affected by the Commonwealth's deposit program. 
Table 3-2: Springfield MRF- Recovered Material Sold, FY 1993

\begin{tabular}{|c|c|c|c|}
\hline $\begin{array}{l}\text { Recovered Material } \\
\text { Components }\end{array}$ & $\begin{array}{l}\text { Annual } \\
\text { Tonnage } \\
\text { Sold }\end{array}$ & $\begin{array}{l}\text { Percent of } \\
\text { Total } \\
\text { Component } \\
\text { Sold } \\
\end{array}$ & $\begin{array}{l}\text { Percent of } \\
\text { Total } \\
\text { Materials } \\
\text { Sold }\end{array}$ \\
\hline \multicolumn{4}{|l|}{ GLASS } \\
\hline Flint & 3,699 & 37.9 & 8.7 \\
\hline Green & 837 & 8.6 & 2.0 \\
\hline Amber & 470 & 4.8 & 1.1 \\
\hline Aggregate Cullet & 4,754 & - 48.7 & 11.2 \\
\hline Subtotal & 9,760 & 100.0 & 23.0 \\
\hline \multicolumn{4}{|l|}{ METALS } \\
\hline Tin Cans & 3,432 & 95.0 & 8.1 \\
\hline Steel Scrap & 33 & 0.9 & 0.1 \\
\hline Other Metals & 0 & 0.0 & 0.0 \\
\hline Aluminum Cans & 107 & 3.0 & 0.3 \\
\hline Aluminum Deposit \& Scrap & 7 & 0.2 & 0.0 \\
\hline Aluminum Foil & 34 & 0.9 & 0.1 \\
\hline Subtotal & 3,612 & 100.0 & 8.5 \\
\hline \multicolumn{4}{|l|}{ PLASTICS } \\
\hline PET & 53 & 14.6 & 0.1 \\
\hline \#4 Plastic & 13 & 3.6 & 0.0 \\
\hline PET Deposit & 6 & 1.6 & 0.0 \\
\hline Other Plastic & 0 & 0.0 & 0.0 \\
\hline Colored HDPE & 97 & 26.5 & 0.2 \\
\hline Clear HDPE & 196 & 53.8 & 0.5 \\
\hline Subtotal & 365 & 100.0 & 0.9 \\
\hline \multicolumn{4}{|l|}{ PAPER } \\
\hline Special Mixed Paper & 659 & 2.3 & 1.5 \\
\hline \#6 News & 13,297 & 46.2 & 31.3 \\
\hline \#7 News & 5,956 & 20.7 & 14.0 \\
\hline \#8 News & 6,143 & 21.3 & 14.5 \\
\hline Corrugated & 2,636 & 9.2 & 6.2 \\
\hline Cartons & 84 & 0.3 & 0.2 \\
\hline Subtotal & 28,775 & 100.0 & 67.7 \\
\hline TOTAL MATERIALS SOLD & 42,512 & & 100.00 \\
\hline
\end{tabular}

Sources:

1. DEP, "Monthly Revenue, Springfield Material Recycling Facility," December 1992, by Charles Leto, Department of Solid Waste Management.

2. DEP, "Monthly Revenue \& Fiscal Year 94, Springfield Material Recycling Facility," January 27, 1993, by Greg Cooper, Department of Solid Waste Management. 
1993, and Figure 3-2 compares the percentage, by weight, of the materials sold to the percentage of revenues received from each type of material. Although aluminum accounted for about 0.3 percent of the materials sold, it contributed almost 14 percent of the revenues received.

The materials recovered were sold to numerous remanufacturers, as shown in Table 3-3. As can be seen from this table, the majority of the material sold was shipped by transfer trailers. The remanufacturers were located throughout the Northeast at distances ranging from 55 to 1,300 miles (one way) from Springfield.

\subsection{Bulky Waste Collection, Processing, and Disposal}

The City collected about 1,316 tons of bulky waste in FY 1993. About 807 tons, or 61.3 percent, of the bulky waste was disposed of at a private landfill operated by the Connecticut Valley Disposal Company. The remaining 509 tons, or 38.7 percent, were white goods and other recyclable metals. This material was sold to Environmental Maintenance Metal Processors of Waterbury, Connecticut, for $\$ 14$ per ton. The white goods are processed to recover ferrous and non-ferrous metals and plastics. About 15 percent, by weight, or 76 tons, is disposed of as residue. The recovered materials are shipped between 110 and 1,200 miles, depending upon market conditions, for remanufacturing.

\subsection{Collection and Disposition of $\mathrm{HHW}^{28}$}

The City sponsored an HHW collection day on May 1, 1993. An estimated 15 tons of material was collected. The types and amounts of materials collected are provided in Table 3-4. About 38 percent of the material was flammable liquids, such as asphalt sealers, that could not be consolidated because of its viscosity or because it was solidified. About 20 percent of the HHW collected was paint-related material, and another 16 percent was consolidated oil. In total, these three classes of materials represent almost 74 percent, by weight, of the HHW collected.

Of the material collected, about 0.4 tons ( 2.7 percent) were treated, 0.5 tons ( 3.1 percent) landfilled, 6.2 tons (42.2 percent) incinerated, and 7.5 tons ( 51.8 percent) recycled. Of the materials recycled, about 44 percent (i.e., consolidated liquid such as mineral spirits, thinners, solvents, and antifreeze, consolidated oil, and consolidated paints) was recycled as a fuel. Thirtyone percent was recycled as paint and the balance of 25 percent was recycled to recover metals and plastic. The automobile lead-acid batteries were shipped to Ontario, Canada for processing. Both lead and plastics were recovered from the batteries.

28 Tonnages are estimated from the number and size of containers (e.g., 55-gallon drums) used to collect each type of HHW. The information was obtained from a telephone discussion between Mr. William Connors, of Clean Harbors of Natick, Inc., and Dr. Alan Cohen, May 25, 1994. 
Figure 3-2: Materials Recovered and Revenues Received in FY 1993

Springfield Materials Recovery Facility
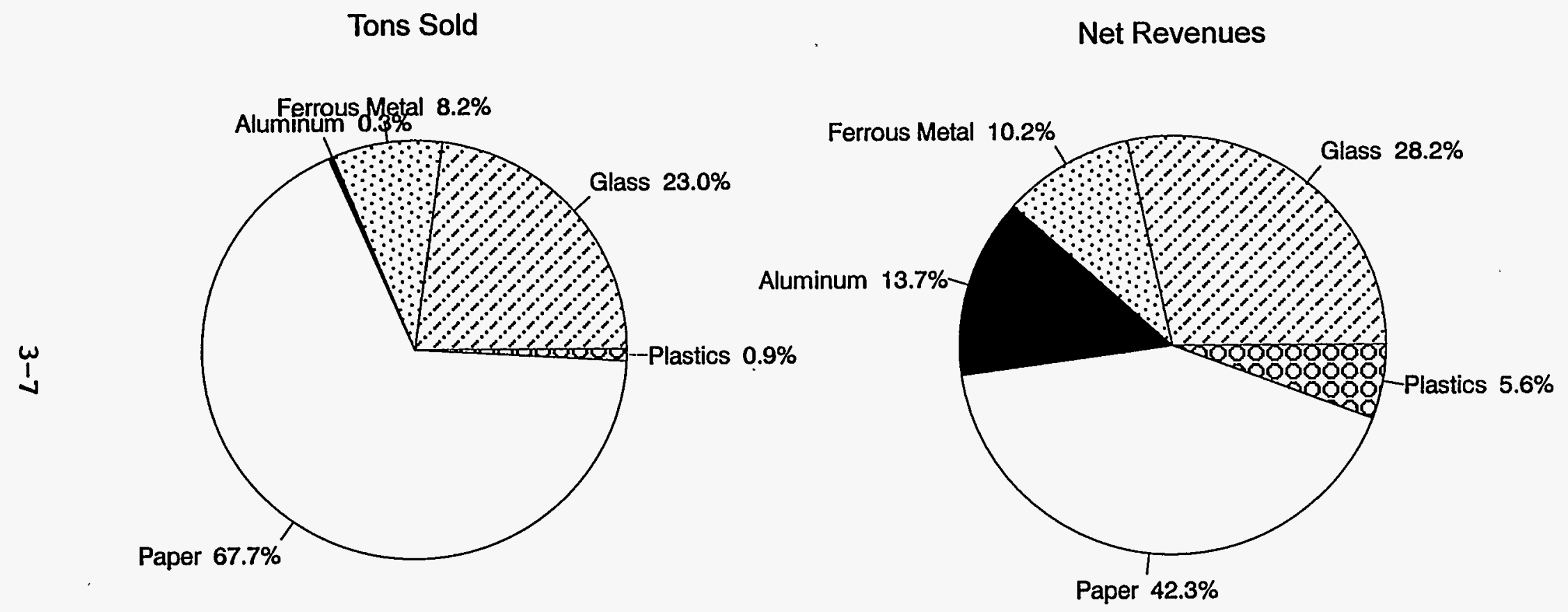
Table 3-3: Markets for Recovered Materials Sold in FY 1992

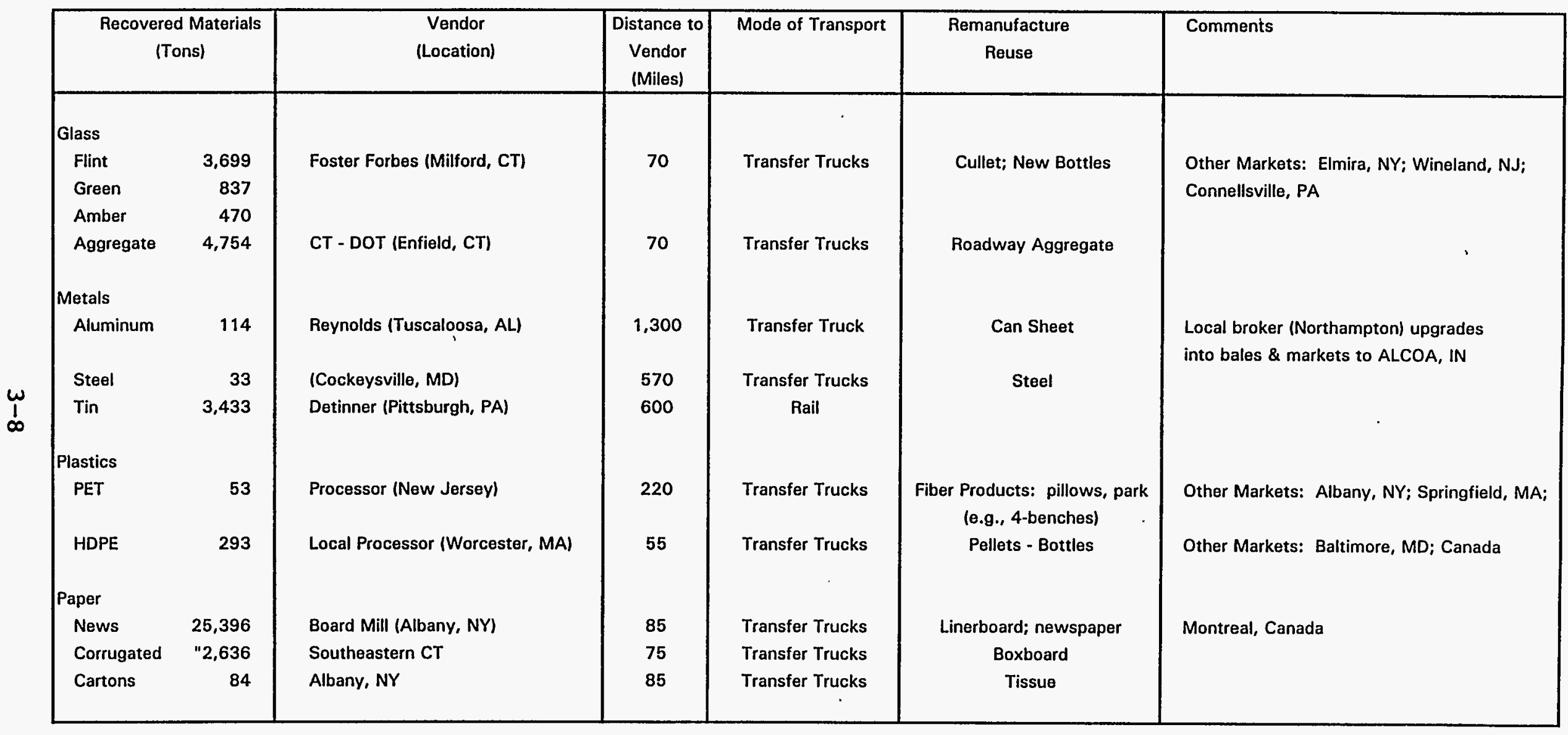


Table 3-4: Collection and Disposition of HHW in FY 1993

\begin{tabular}{|c|c|c|c|c|c|}
\hline Type of HHW & $\begin{array}{c}\text { Cont } \\
\text { Size } \\
\text { (Gal.) }\end{array}$ & $\begin{array}{l}\text { No. } \\
\text { Cont. }\end{array}$ & Tons & $\begin{array}{l}\text { Percent } \\
\text { of Total }\end{array}$ & Disposition \\
\hline Acids (Lab Pack) & 55 & 1 & 0.11 & 0.75 & Aqueous Treated \\
\hline Alkalines (Lab Pack) & 55 & 1 & 0.11 & 0.75 & Aqueous Treated \\
\hline Oxidizers & 55 & 1 & 0.11 & 0.75 & Aqueous Treated \\
\hline Oxidizers & 5 & 1 & 0.01 & 0.07 & Aqueous Treated \\
\hline Alkalines (Lab Pack) & 55 & 1 & 0.11 & 0.75 & Aqueous Treated/Landfilled \\
\hline Consolidated Liquids (with PCB's) & 55 & 1 & 0.22 & 1.51 & Incinerated \\
\hline Flamable Liquids Can't Be Consolidated & 55 & 25 & 5.50 & 37.66 & Incinerated \\
\hline Organics (Lab Pack) & 16 & 9 & 0.29 & 1.97 & Incinerated \\
\hline Alkalines (Lab Pack) & 16 & 2 & 0.06 & 0.44 & Incinerated \\
\hline Water Reactive Compounds & 5 & 1 & 0.01 & 0.03 & Incinerated \\
\hline Alkalines (Lab Pack) & 5 & 1 & 0.01 & 0.07 & Incinerated \\
\hline Organics (Lab Pack) & 5 & 1 & 0.01 & 0.07 & Incinerated \\
\hline Flamables (Lab Pack) & 5 & 2 & 0.02 & 0.14 & Incinerated \\
\hline Pesticides (Lab Pack) & 55 & 1 & 0.11 & 0.75 & Incinerated/landfilled \\
\hline Pesticides (Lab Pack) & 16 & 1 & 0.03 & 0.22 & Incinerated/landfilled \\
\hline Organics (Lab Pack) & 55 & 2 & 0.22 & 1.51 & Landfilled \\
\hline Asbestos Containing Items & 55 & 1 & 0.04 & 0.27 & Landfilled \\
\hline Aerosol Cans & 55 & 1 & 0.04 & 0.27 & Landfilled \\
\hline Household Batteries & 5 & 2 & 0.03 & 0.21 & Landfilled \\
\hline Consolidated Liquids & 55 & 2 & 0.44 & 3.01 & Recyced as Fuel \\
\hline Consolidated Oil & 55 & 11 & 2.27 & 15.54 & Recyced as Fuel \\
\hline Consolidated Paint & 55 & 3 & 0.62 & 4.24 & Recyced as Fuel \\
\hline Automobile Batteries & & 200 & 0.90 & 6.16 & Recycled \\
\hline Empty Metal (e.g., Paint) Cans & & & 1.00 & 6.85 & Recycled \\
\hline Latex Paints & & & 1.13 & 7.70 & Recycled \\
\hline Solvent Based Paints & & & 1.21 & 8.29 & Recycled \\
\hline Totals & & & 14.60 & 100.00 & \\
\hline
\end{tabular}

\section{Sources:}

1. Telephone conversation with Mr. William Connors, Clean Harbors of Natick, Inc., May 25, 1994.

2. "Paint Collection Tally," The Green Paint Company, May 1, 1993. 



\section{Cost of MSW Management in Springfield}

\subsection{Summary of Results}

Of the 61,230 tons of MSW managed within the City, approximately 59,900 were analyzed ("Analyzed MSW") ${ }^{29}$ to determine the cost of Springfield's IMSWM System. The cost to manage the $\mathrm{HHW}$ is treated separately.

\subsubsection{Overall Program Costs}

The total FY 1993 gross cost to manage Analyzed MSW was about $\$ 9.72$ million. The cost net of revenues received from the sale of materials and energy was $\$ 7.17$ million, or about $\$ 120$ per ton. This net cost breaks downs to, in rounded numbers:

\begin{tabular}{lccc}
\hline Category & Tonnage & $\begin{array}{c}\text { Net Cost } \\
\text { (\$ millions) }\end{array}$ & Net Cost Per Ton \\
\hline Garbage & 44,700 & $-\$ 5.60$ & $\$ 125$ \\
Recyclables & 7,580 & $\$ 1.01$ & $\$ 136$ \\
Yard Waste & 6,810 & $\$ .38$ & $\$ 57$ \\
Bulky Waste & 807 & $\$ .16$ & $\$ 197$ \\
Total/Average & 59,900 & $\$ 7.17$ & $\$ 120$ \\
\hline
\end{tabular}

The FY 1993 cost of managing about 15 tons of HHW was approximately $\$ 33,600$, or over $\$ 2,200$ per ton.

As shown in Figure 4-1, the WTE facility is the most significant factor in the total gross cost of the Springfield IMSWM System, but collection costs become most significant when system revenues are considered. Figure 4-2 shows the allocation of net costs to the key functional areas (i.e., collection, landfill, and G\&A) for each of the program areas. Note that, with the exception of the management of garbage and HHW, collection costs amount to about half the management costs. In the case of garbage, the cost of the WTE facility is about equal to that of collection.

\subsubsection{Program Incremental Costs}

The incremental cost for each resource recovery program, i.e., the cost (or savings) associated with adding the program to the IMSWM System, is the difference between the cost of managing all of the MSW with and without the inclusion of that program. The Program Incremental Cost (or Savings) is, therefore, an appropriate measure on the cost of managing MSW. The FY 1993 Program Incremental Cost (Savings) for each of the City's resource recovery programs was, in

${ }^{29}$ Generally speaking, Analyzed MSW is all the MSW that is collected by or on behalf of the City. 
Figure 4-1: Allocation of Total Costs For IMSWM System in FY 1993

Allocation by Functional Area

(Cost to Manage 59,900 Tons of Analyzed MSW)

Gross Cost is $\$ 9,720,000$

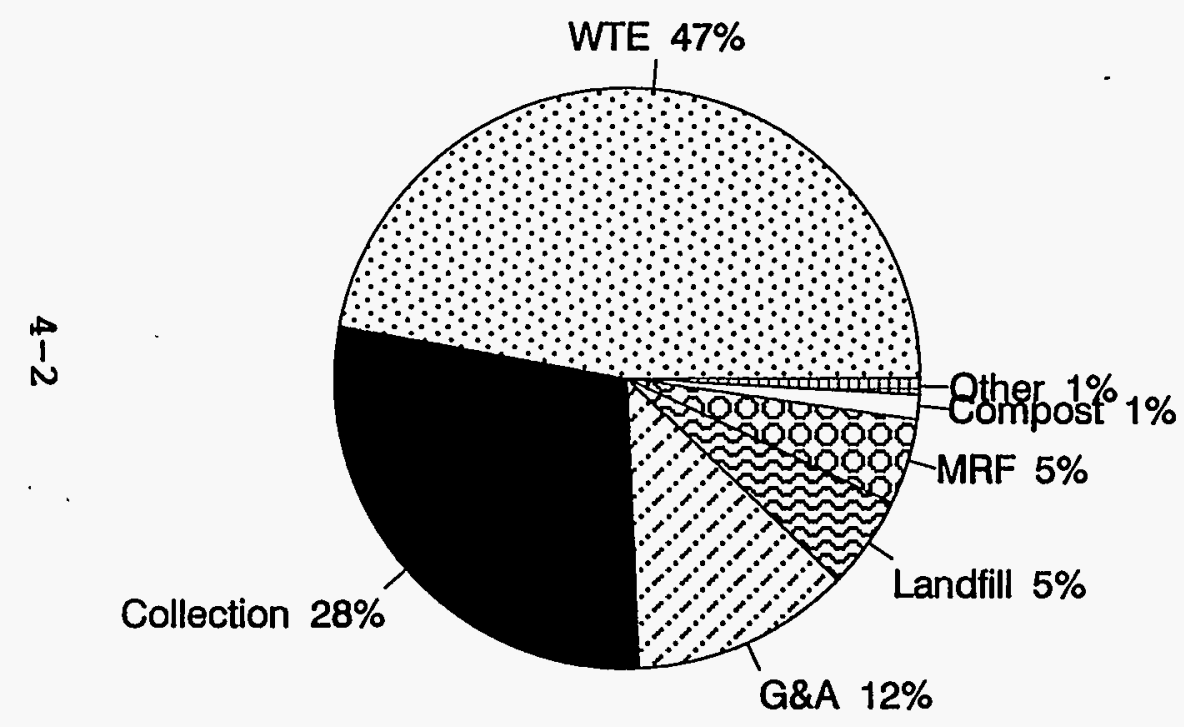

Net Cost is $\$ 7,170,000$

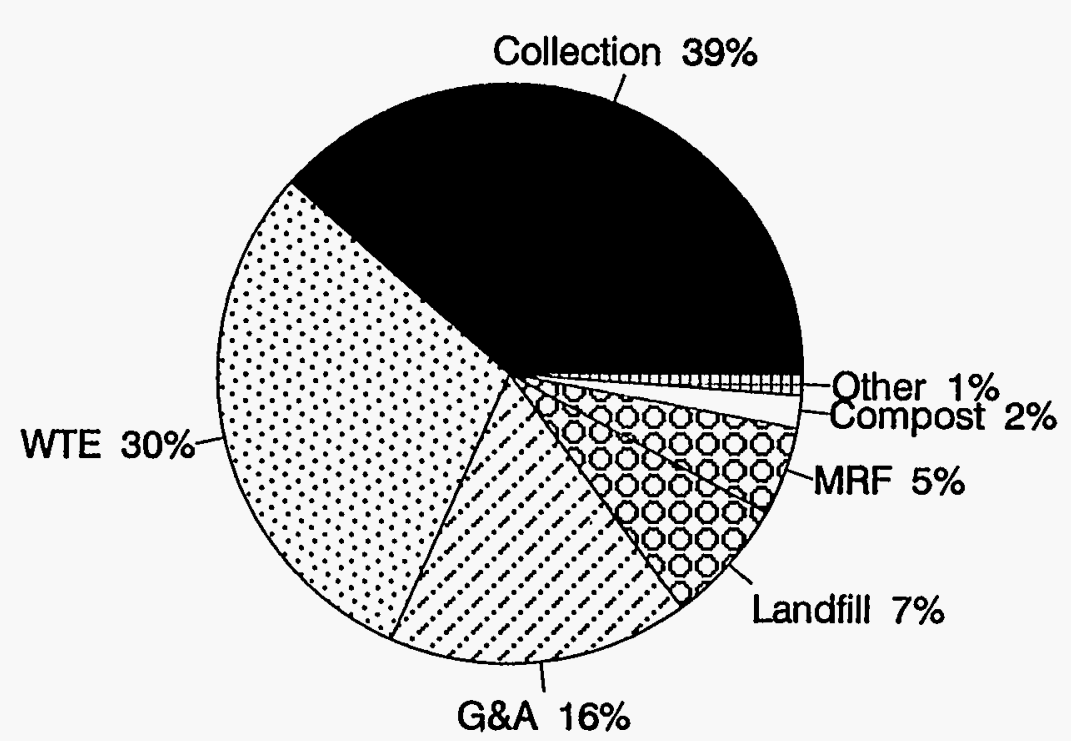



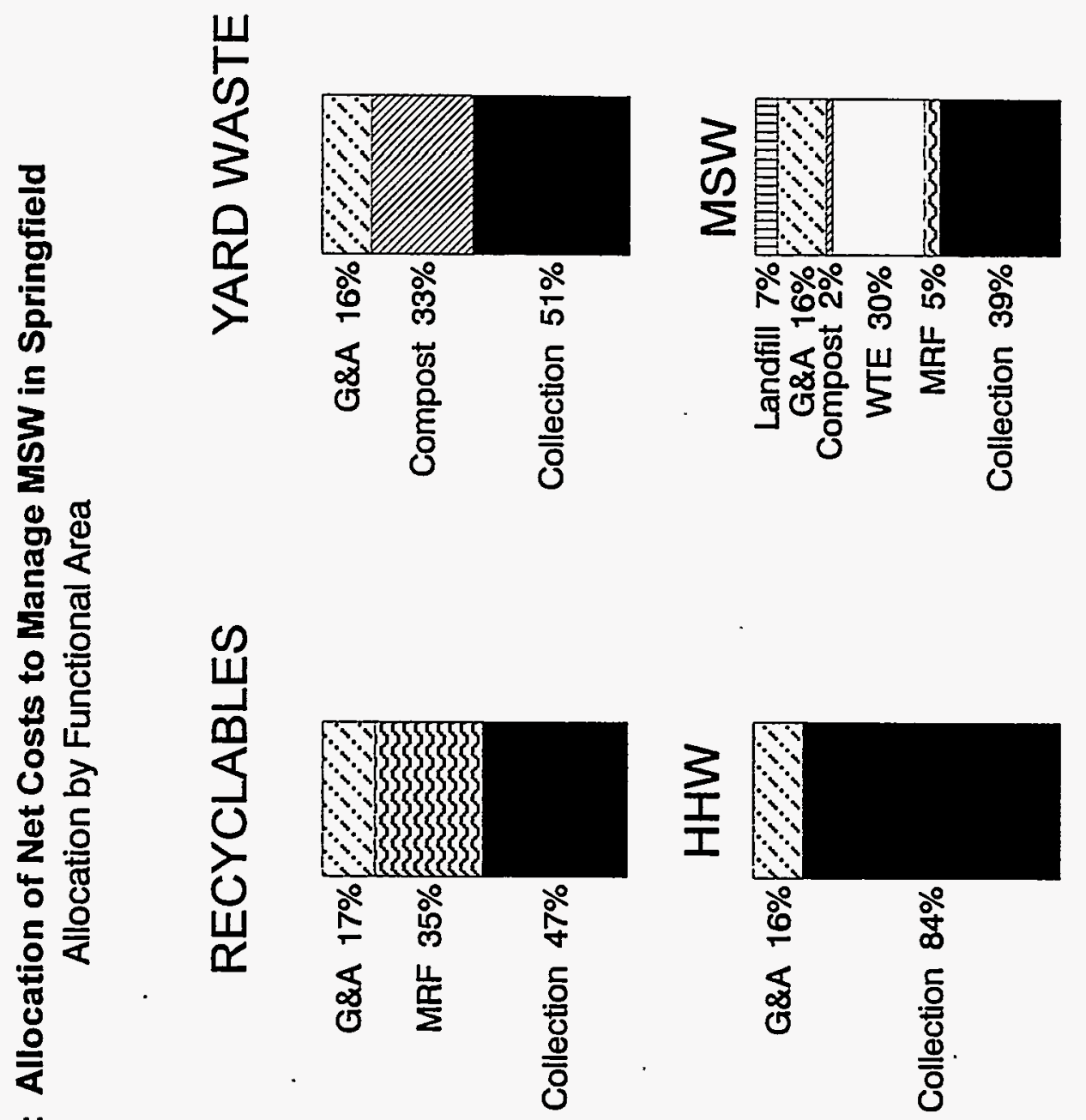

守

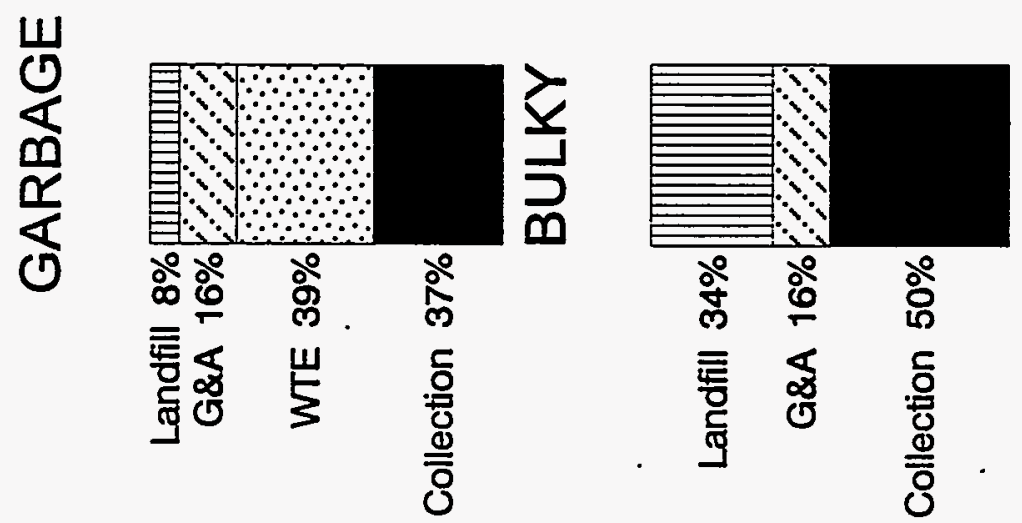

4-3 
rounded numbers:

\begin{tabular}{lccc}
\hline Program & Tonnage & \multicolumn{2}{c}{$\begin{array}{c}\text { Incremental Cost } \\
\text { (Savings) }\end{array}$} \\
\cline { 3 - 4 } & & Dollars & $\$$ Per Ton \\
\hline Waste-to-Energy & 45,677 & $\$ 322,500$ & $\$ 7$ \\
Curbside Recycling & 6,958 & $\$ 774,500$ & $\$ 111$ \\
Yard Waste Composting & 7,515 & $\$ 274,000$ & $\$ 36$ \\
Office Paper Recycling & 22 & $\$ 1,500$ & $\$ 68$ \\
White Goods Recycling & 509 & $\$(41,300)$ & $\$(81)$ \\
\hline
\end{tabular}

In addition to the incremental cost or savings that can be attributed to each of the resource recovery programs, each of them contributes resources to the economy and reduces the utilization of available landfill space. These attributes are summarized in Table 4-1.

The sections that follow, and their supporting Appendices, provide the detail behind these overall results. Section 4.2 defines that portion of the waste stream for which collection costs are known, i.e., "Analyzed MSW." Section 4.3 presents the total cost incurred by the City for the management of the approximately 59,900 tons of Analyzed MSW. In Sections 4.4 and 4.5 these costs are allocated by functional area and type of MSW (i.e., residential garbage, recyclables, yard waste, bulky waste, and HHW), respectively. Program incremental costs are provided in Section 4.6.

\subsection{Apportionment of Waste Stream}

Only a portion of the total MSW stream (i.e., Analyzed MSW) described in Section 3 is included in the economic analyses presented in this Section. The reason for limiting the tonnage included in the analysis is to include only that portion of the MSW stream for which the total cost of collection, processing, combusting, composting, marketing, and disposal is known. Failure to limit the economic analysis to the tonnage and costs associated with Analyzed MSW would bias the results and could result in misleading conclusions.

The Analyzed MSW in this Section excludes self-hauled (resident drop-off), street-swept leaves, and imported yard waste (other towns), as well as HHW. The cost of collecting this portion of the waste stream is not known and cannot be reasonably estimated within the scope of this study. Thus, both the costs and quantities (i.e., 1,308 tons of yard waste and 15 tons of HHW) are excluded from the analysis. ${ }^{30}$ In addition to the MSW managed by the City, 15,594 tons of other wastes are collected by the City and disposed of at the Bondi's Island Landfill. Such wastes

${ }^{30}$ Although HHW is not included in the definition of Analyzed MSW, a separate analysis of the costs incurred by the City for the HHW program, exclusive of the costs incurred by individuals to transport HHW to the collection site, is provided in Section 4.4.5. 
Table 4-1: Springfield FY 1993 Rresource Recovery Program Incremental Costs/Effectiveness

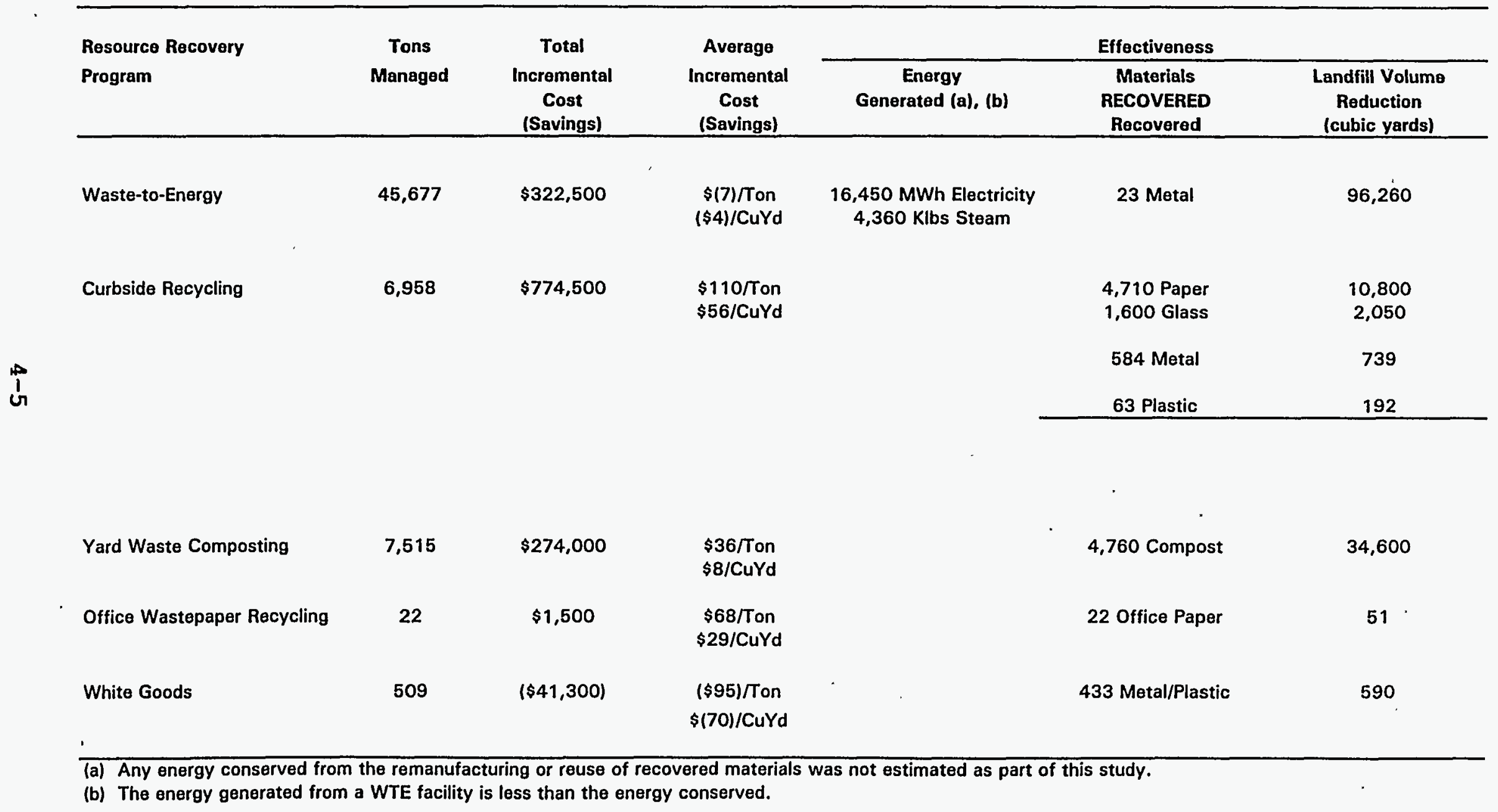


comprise sewage sludge, unused sludge compost, wastewater treatment plant grits and screening, street sweepings, and catch basin/sewer cleanings (see Table C. 6 of Appendix C for details). The costs and quantities of these other wastes are also excluded from the analysis.

Table 4-2 shows the FY 1993 tonnages of the components of both the total MSW and Analyzed MSW (i.e., without self-hauled, street-swept, and imported yard waste and HHW, for which collection costs are unknown).

When a portion of the MSW stream is excluded from an analysis performed in this section because its collection costs are unknown, the associated processing, composting, marketing, and disposal costs are also excluded from the analysis. Consequently, the cost comparisons among types of MSW are valid and include all the costs required to manage the Analyzed MSW stream from the time when it is placed at the curb until it is sold, re-used, or disposed of in a landfill.

\subsection{Gross and Net Costs of Analyzed MSW Management}

The gross cost of managing Analyzed MSW represents costs only, i.e., it does not include any revenues derived from recovered materials or energy. The net cost of Analyzed MSW management includes costs and revenues (i.e., the gross cost offset by revenues). The gross and net costs of collecting, processing, combusting, composting, marketing recovered materials, and disposing of the approximately 59,900 tons of Analyzed MSW in FY 1993 were approximately $\$ 9.72$ million and $\$ 7.17$ million, respectively. This represents an Average Net Cost of $\$ 120$ per ton.

These costs were calculated by determining the total Analyzed MSW management expenses incurred in FY 1993; adjusting these costs as appropriate to satisfy the requirements of this study; and allocating costs to determine that portion of the adjusted costs attributed to the management of the FY 1993 Analyzed MSW.

\subsubsection{City Reported Costs}

The costs of the Springfield IMSWM System are borne by numerous City, State, and private entities. The Springfield DPW's Solid Waste Division is primarily responsible for the day-to-day collection and management of MSW. Many services, such as vehicle and equipment maintenance, legal and procurement services, and facilities maintenance are performed by other DPW divisions or City departments. Other services, such as operation of the Bondi's Island Landfill and operation of the WTE facility, are provided by private contractors. The Commonwealth of Massachusetts pays all of the MRF capital and operating costs. Also, the Commonwealth paid for the cost of the recycling bins, but residents are responsible for purchasing kraft paper bags and/or cans for yard waste collection and plastic bags and/or cans for garbage collection.

Since MSW management in Springfield is paid for from general revenues and is not treated as an enterprise system, a consolidated accounting of the costs of managing MSW in Springfield is not available. Instead, CSI determined the gross and net costs by compiling information provided by the City, the Commonwealth, and private contractors. The methodology, assumptions, and data used to calculate the gross and net costs of MSW management in Springfield are presented in Appendix C. The method used to determine the portion of these costs attributed to Analyzed MSW, functional areas, and waste types are presented in Appendices B and C. 
Table 4-2: FY 1993 Total MSW and Analyzed MSW Tonnages by Component

\begin{tabular}{|c|c|c|c|}
\hline MSW Components & $\begin{array}{l}\text { Total } \\
\text { MSW } \\
\text { (tons) } \\
\end{array}$ & $\begin{array}{c}\text { Analyzed } \\
\text { MSW } \\
\text { (tons) }\end{array}$ & $\cdots$ \\
\hline \multicolumn{4}{|l|}{ GARBAGE } \\
\hline City Collected to WTE & 44,707 & 44,707 & \\
\hline \multicolumn{4}{|l|}{ YARD WASTE } \\
\hline City Collected to Compost Site & 6,814 & 6,814 & \\
\hline Street Sweepings & 337 & & \\
\hline Self Haul to Compost Site & 364 & & \\
\hline Agawam & 607 & & \\
\hline Subtotal Yard Waste & 8,122 & 6,814 & . \\
\hline \multicolumn{4}{|l|}{ RECYCLABLES } \\
\hline City Collected to MRF & 7,048 & 7,048 & \\
\hline High Grade Office Paper & 22 & 22 & \\
\hline Subtotal Recyclables & 7,070 & 7,070 & \\
\hline \multicolumn{4}{|l|}{ BULKY WASTES } \\
\hline White Goods & 509 & 509 & \\
\hline Others & 807 & 807 & \\
\hline Subtotal Bulky Waste & 1,316 & 1,316 & \\
\hline HOUSEHOLD HAZARDOUS WASTE & 15 & & \\
\hline TOTALS & 61,230 & 59,907 & \\
\hline
\end{tabular}


The results of the analyses presented in Appendices B and C are provided in Table 4-3. This table shows an itemized net cost of $\$ 8.27$ million for MSW-related management and a net cost for managing the 59,900 tons of Analyzed MSW of $\$ 7.17$ million. It should be noted that this itemized net cost ( $\$ 8.27$ million) is not the same as the gross cost of Analyzed MSW management. The itemized net cost represents the net costs involved in managing MSW and other wastes.

\subsubsection{Adjustments to the Reported Costs and Assumptions Made to Calculate Itemized Net Cost}

Some of the more important adjustments made to the reported costs and key assumptions used to determine the itemized net cost shown in Table 4-3 are discussed below. The purpose of this section is to provide the reader with a sense of the adjustments and assumptions made. See Appendix $\mathrm{C}$ for a complete discussion of the methodology, data, and assumptions used.

- The reported DPW costs did not account for some fringe benefits such as insurance and retirement. Furthermore, the actual cost of these benefits is not specifically accounted for by the City. In this analysis 35 percent of the regularhour direct labor costs was added to the reported costs to account for these fringe benefits.

The City does not maintain a fixed asset account, making it impossible to determine the costs of office space, furnishings, and equipment that make up G\&A capital costs. In this analysis the G\&A O\&M cost was increased by 10 percent to account for these capital costs. This factor is based on results from other communities that do maintain fixed asset accounts.

- Data from monthly invoices from the WTE facility and Bondi's Island Landfill contractors were used instead of the reported costs for these services. This was done because some of the year-end charges were not processed prior to the closing of the City's FY 1993 books.

- The actual cost of ash disposal at the Bondi's Island Landfill was substituted for the ash disposal passthrough cost charged by the WTE facility contractor. Since the WTE facility contractor pays the City for all of the ash disposed of at the Bondi's Island Landfill, the City is actually reimbursed for the ash disposal portion of the passthrough cost. Furthermore, the City paid the landfill operator for the disposal of this ash. The price paid by the WTE facility contractor to the City for ash disposal is a negotiated price and is not necessarily equal to the cost incurred by the City for ash disposal.

- The O\&M and capital costs of fleet vehicles and equipment used to collect and or process MSW are explicitly accounted for in the analysis. Capital costs are calculated using the procedure described in Appendix D.

- Landfill closure and post-closure monitoring costs are explicitly accounted for in the analysis. These costs reflect an amount that would have to be deposited into an escrow account in order to have sufficient funds available at the time the 
Table 4-3: Net Costs for the Springfield IMSWMS System (FY 1993)

\begin{tabular}{lrr}
\hline Activity & $\begin{array}{r}\text { Total } \\
\text { Cost }\end{array}$ & $\begin{array}{r}\text { Analyzed } \\
\text { MSW }\end{array}$ \\
\hline Solid Waste Division Job Cost Data & $\$ 2,823,338$ & $\$ 2,424,179$ \\
Vehicle and Equipment O\&M and Capital Expenses & 776,054 & 747,082 \\
Bondi's Island Cell \#1 Landfill Contractor Fees & 783,558 & 193,816 \\
Bondi's Island Cell \#1 Landfill Capital Cost & 159,807 & 159,807 \\
Bondi's Island Cell \#1 Landfill Closure Costs & 91,081 & 91,081 \\
Bulky Waste Landfill Tip Fees & 54,166 & 54,166 \\
Waste-to-Energy Facility Service Fee & $2,123,546$ & $2,123,546$ \\
MRF Capital \& Net O\&M Costs & 354,256 & 354,256 \\
HHW Collection Day Contractor Fees & 28,146 & 0 \\
Bins, Cans, \& Bags & 620,250 & 620,250 \\
DPW G\&A Capital and O\&M Expenses & 185,540 & $160 ; 683$ \\
City G\&A Capital and O\&M Expenses & 184,800 & 160,042 \\
Solid Waste Division G\&A Capital Cost & 86,310 & 74,747 \\
DEP G\&A Capital and O\&M Expenses & 12,350 & 12,350 \\
White Good Revenues & $(7,126)$ & $(7,126)$ \\
Compost Revenues & $(3,784)$ & $(3,174)$ \\
Totals & & \\
\cline { 2 - 3 } & $\$ 8,272,000$ & $\$ 7,166,000$ \\
\hline
\end{tabular}


landfill is closed to properly close the landfill and monitor it for 30 years.

- The Bondi's Island Landfill capital cost is based on the average development and construction cost per cubic yard of capacity multiplied by the actual cubic yards of ash disposed of in FY 1993. Only the ash generated from the City's Analyzed MSW was included in the analysis. The volume of cover material used at the landfill is assumed to be 15 percent of the volume of the ash requiring disposal.

- In addition to the garbage delivered to the WTE facility by the DPW, the City also delivered about 970 tons of waste collected by other City departments such as parks, public housing, and wastewater treatment. None of the costs related to this waste stream are included in the analysis of Analyzed MSW. Furthermore, since the City did not satisfy its Annual Tonnage Commitment at the WTE facility, none of the costs associated with the WTE facility were affected by this additional waste.

\subsubsection{Determining the Net Cost of Managing Analvzed MSW}

About $\$ 111$ million of the itemized net cost shown in Table 4-3 is not related to the management of the Analyzed MSW. Components of this cost are identified as "Not Applicable" in Tables B.1 through B.10 of Appendix B. The most important of these costs are discussed below.

Of the $\$ 783,600$ paid to the Bondi's Island Landfill contractor in FY $1993, \$ 589,900$, or about 75 percent, was not related to the disposal of the Analyzed MSW. This $\$ 589,900$ landfill cost was paid by the City for the disposal of about 23,800 tons of as-received ash generated from MSW delivered to the WTE facility by other cities and about 15,600 tons of other waste (e.g., sludge, sludge compost, street sweepings) delivered to the landfill by the City. The $\$ 193,800$ Bondi's Island Cell \#1 Landfill Contractor Fee shown in Table 4-3 as being attributable to the Analyzed MSW, is the share of the contractor fees allocated to the disposal of the 14,800 tons of ash generated from MSW delivered to the WTE facility by the City. An additional $\$ 71,600$ was spent at the landfill for expansion and maintenance that are not related to the disposal of ash in Cell \#1. In total, the $\$ 661,000$ landfill cost that is not related to the management of the Analyzed MSW accounts and for about 57 percent of the difference between the itemized net cost and the net cost of managing Analyzed MSW shown in Table 4-3.

About 72 percent, or $\$ 196,850$ of "Other Costs" show in Table B.9 in Appendix B are unrelated to the management of the Analyzed MSW. These include the costs of street sweeping, cleaning catch basins, and participation in special events.

The $\$ 28,100$ payment to the contractors that participated in the HHW collection day and the $\$ 8,100$ cost of the Solid Waste Division workers assigned to transfer self-hauled yard waste from the Bondi's Island Landfill to the composting site are also excluded from the cost of managing Analyzed MSW. Finally, about $\$ 32,200$ of the net compost operation O\&M and capital costs is attributable to the processing and marketing of compost from self-hauled and imported yard waste.

The sum of these costs (i.e., $\$ 590,000+\$ 71,600+\$ 196,900+\$ 28,100+\$ 8,100+\$ 32,200$ ) accounts for over 83 percent of the difference between the itemized net cost and the cost of managing Analyzed MSW shown in Table 4-3. The balance of the difference is the G\&A cost 
allocated to the activities discussed above.

\subsection{Allocation of Costs by Functional Area}

Within this section, the $\$ 9.72$ million gross cost and $\$ 7.17$ million net cost for managing the 59,900 tons of Analyzed MSW is allocated among the functional areas of G\&A, collection, wasteto-energy, materials recovery facility, and composting. The City incurred some miscellaneous recycling expenses, but they were less than 0.1 percent of the net cost. ${ }^{31}$ To make these allocations, each detailed expenditure was categorized by functional area. Figure 4-1 provided the resulting percentage allocation by functional area. The allocation of net costs was estimated by subtracting the revenues received from the sale of electricity and steam from the WTE facility gross cost, the sale of recovered materials from the MRF gross cost; the sale of compost from the composting operation gross cost; and the sale of white goods from the white good operation gross cost (this is included in Other Costs).

Forty-seven percent of the gross cost is attributed to the WTE facility; 28 percent to collection; 12 percent to G\&A expenses, 5 percent to landfill disposal, 5 percent to the MRF, 1 percent to the compost operation, and 1 percent to other costs (principally litter control and white good recycling). However, when accounting for the revenues earned from various resource recovery activities, collection costs account for 39 percent; the WTE facility 30 percent; G\&A expenses 16 percent; landfilling 7 percent; the MRF 5 percent; the composting operation 2 percent; and other costs 1 percent of the net cost.

An estimated 71 percent of the gross cost was O\&M expenses and about 29 percent was capital costs. The percentages of O\&M and capital costs for each function are presented in Figure 4-3.

The gross G\&A cost was about $\$ 1.18$ million. The 10-percent G\&A capital cost reflects the assumption made in this analysis that 10 percent of the G\&A O\&M costs is attributed to office space, furnishings, and equipment. The capital cost of the vehicles used by administrative personnel are also included in the G\&A capital cost.

About 82 percent of the $\$ 2.8$ million gross collection cost was O\&M expenses and 18 percent was capital costs. This reflects the non-capital-intensive nature of collection. On the other hand, the landfill, the WTE facility, MRF, and compost operation are relatively capital intensive. About 31 percent of the landfill, 39 percent of WTE facility, 38 percent of the MRF, and 49 percent of the compost operation gross costs were capital costs. ${ }^{32}$ The costs shown in Figure 4-3 allocated to the WTE facility, MRF, compost operation, and landfill represent the costs attributable

${ }^{31}$ The City did not incur large promotional and educational expenses to support recycling. Rather, the City worked with the Commonwealth to promote recycling. This study did not include a specific accounting of promotion and educational costs incurred by the Commonwealth. It is assumed that these expenses are included in the Commonwealth's estimated G\&A cost for the MRF.

32 This is only an estimate of the split of O\&M and capital costs because the actual capital and O\&M costs of the WTE facility and the MRF are not known. The capital charge portion of the WTE Service Fee is assumed to approximate its capital cost. The capital cost of the MRF reflects the cost to the Commonwealth of the building and the Fixed Fee charged by the contractor. 
Figure 4-3: Percent Gross O\&M and Capital Costs by Function in FY 1993

(Cost to Manage 59,900 Tons of Analyzed MSW)

(Cost in Millions of Dollars)

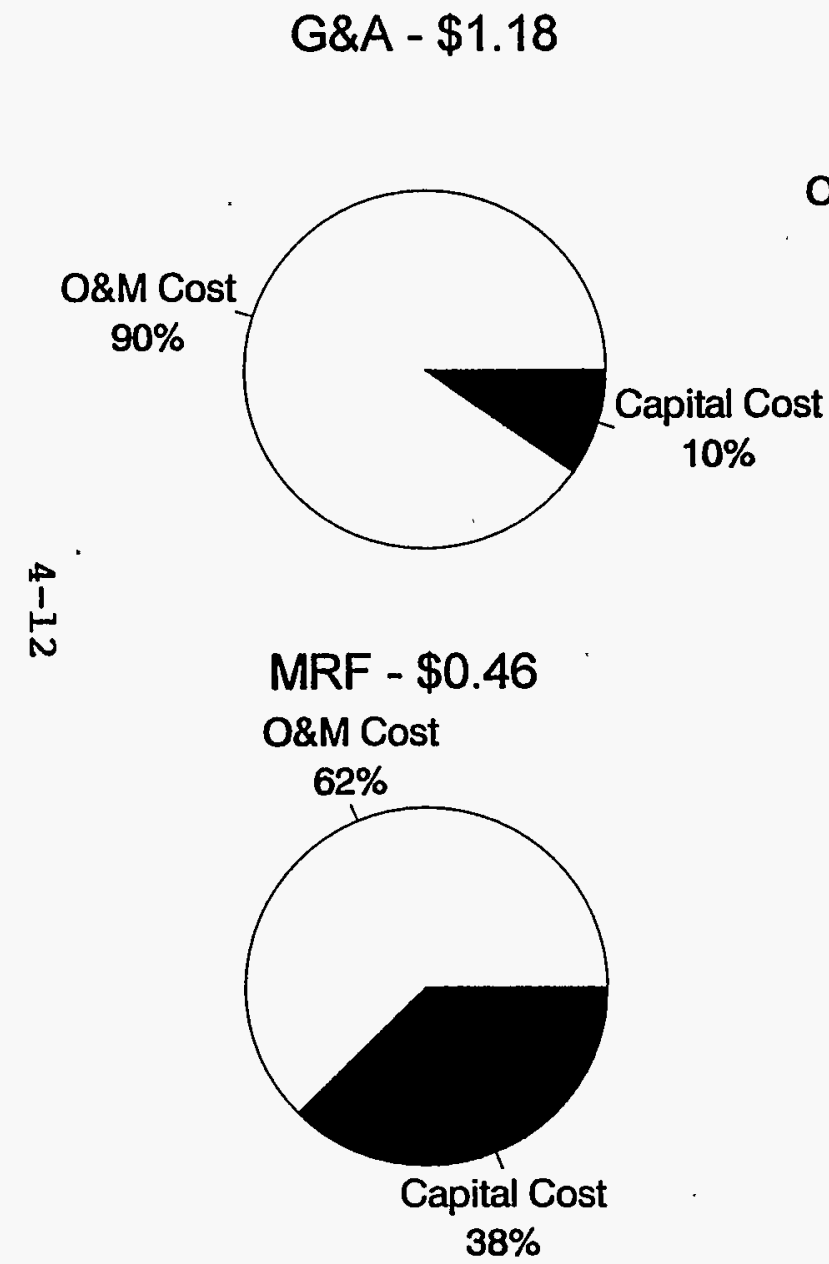

Collection - $\$ 2.8$

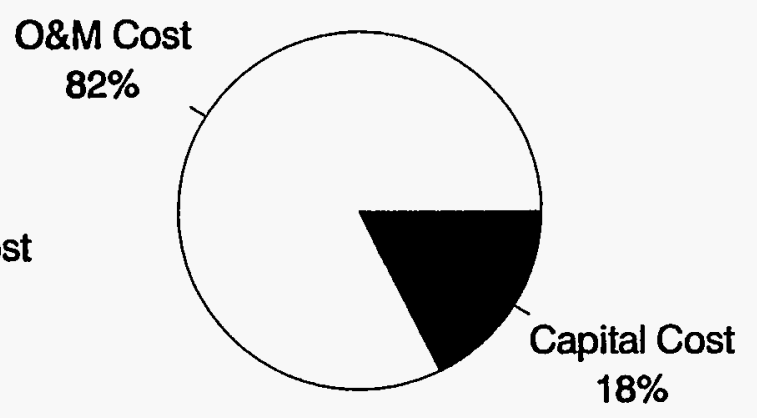

Compost - $\$ 0.13$

O\&M Cost

$51 \%$

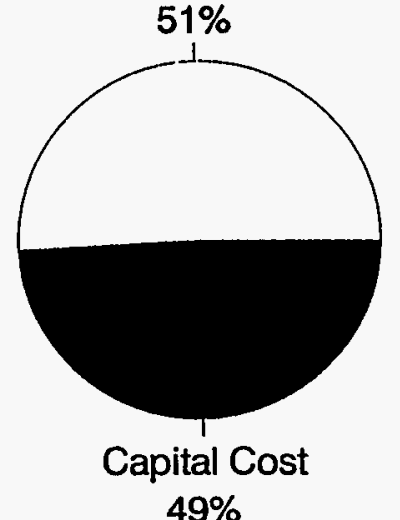

WTE - $\$ 4.6$

O\&M Cost

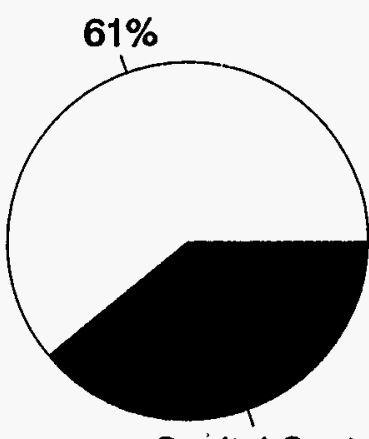

Capital Cost

$39 \%$

Landfill - $\$ 0.51$

O\&M Cost

$69 \%$

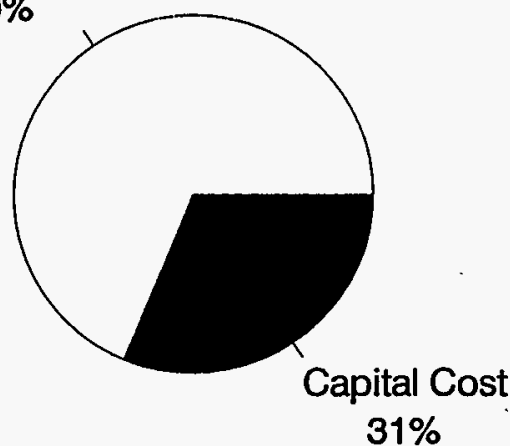


allocated to the WTE facility, MRF, compost operation, and landfill represent the costs attributable to the 59,900 tons of Analyzed MSW. Moreover, the cost of ash disposal is allocated to the landfill and not to the WTE facility. In the following subsections, the total costs for all the waste processed at the WTE facility, MRF, compost operation, and landfill are presented.

\subsubsection{Cost of the Waste-to-Energy Facility}

The WTE contractor provides an estimated Service Fee at the beginning of each fiscal year. At the end of the year the Service Agreement calls for a reconciliation of the Service Fee. ${ }^{33}$ To date no such reconciliation of the FY 1993 estimated Service Fee has occurred. Therefore, for the purpose of this study, the actual Service Fee is equal to the contractor's estimated service fee.

The estimated FY 1993 Annual Service Fee at the WTE facility was about $\$ 4,732,000$, which is equal to the sum of an .O\&M Charge of $\$ 2,989,000$, a Capital Charge of $\$ 3,261,000$, and Passthrough Costs of $\$ 2,922,000$ less Energy Revenues of $\$ 4,440,000$. Ash disposal costs, based on a negotiated price, constituted $\$ 865,000$ of the estimated passthrough cost.

The participating communities have made an Annual Guaranteed Tonnage Commitment of 105,700 tons. $^{34}$ In FY 1993 the City of Springfield's Annual Guaranteed Tonnage was 58,040 tons, or 54.91 percent of the total. ${ }^{35}$ The average cost for the Guaranteed Tonnage was about $\$ 44.80$ per ton (i.e., $\$ 4,732,000$ divided by 105,700 ). The City of Springfield only delivered 45,677 tons of waste to the WTE facility in FY 1993. Because the City did not meet its Annual Guaranteed Tonnage Commitment, its average cost at the WTE facility was $\$ 56.90$ per ton. ${ }^{36}$

In FY 1993 a participating community would have paid a maximum of $\$ 15.90$ per ton for any excess tonnage, but less than 110 percent of its Guaranteed Tonnage, delivered to and accepted at the WTE facility. ${ }^{37}$ The Service Agreement also provided for credits and adjustments for private waste processed at the WTE facility. No such credits were provided to the City of Springfield in FY 1993.

\footnotetext{
33 "Springfield Resource Recovery Project, Restated Solid Waste Disposal Service Agreement," July 1, 1986, Section 6. F.

34 "Springfield Resource Project, Restated Solid Waste Disposal Agreement," July 1, 1986, Appendix

35 To assist in the development of the WTE project, the City of Springfield committed to deliver a minimum of 87,600 tons, or almost 83 percent of the Annual Guaranteed Tonnage. Since the City made this commitment, six additional communities have joined the project, thus reducing Springfield's Guaranteed Tonnage.
}

${ }^{36}$ This cost includes the ash disposal fee included in the passthrough cost and not the actual cost of ash disposal at the landfill.

37 A participating community would have paid less than this amount if the average Service Fee, accounting for an incremental waste-processing credit approximating a 50 percent revenue share, is less than $\$ 15.90$ per ton. (See Section 6.4(f), page 48 of "Springfield Resource Recovery Project, Restated Solid Waste Disposal Service Agreement," July 1, 1986.) 


\subsubsection{Cost of the Materials Recovery Facility}

The FY 1993 O\&M and capital cost of the MRF, as reported by the DEP, was $\$ 2,207,714$ (see Table C.8 of Appendix C). The $\$ 2,207 ; 714$ net cost incurred by the Commonwealth includes the costs paid to the operator of the MRF and the capital cost incurred to build the MRF.

In FY 1993 the MRF operator was paid $\$ 1,603,844$. This was equal to the sum of the $\$ 478,656$ Fixed Fee, the $\$ 740,080$ Variable Fee, and the $\$ 385,107$ revenue makeup..$^{38}$ A total of $\$ 665,447$ was earned from the sale of recovered materials in FY 1993. This amount was kept by the contractor. Therefore, the contractor's gross earnings (i.e., O\&M cost) at the MRF was the sum of $\$ 1,603,844$ and $\$ 665,447$, or $\$ 2,269,291$.

The DEP indicated that the cost to develop and construct the facility (building only) was $\$ 5.5$ million. The annual capital cost of $\$ 603,870$ was estimated using the procedure described in Appendix D. A 7 percent cost of capital and a 15-year useful life of the building was assumed.

The net O\&M and capital cost for the MRF of $\$ 2,207,714$ is the sum of the gross O\&M cost paid to the contractor and the capital costs paid by the Commonwealth less the revenues received from the sale of recovered materials, i.e., $\$ 2,269,291$ plus $\$ 603,870$ minus $\$ 665,447$.

A total of 44,060 tons of recyclables were received at the MRF from the $90+$ communities that delivered recyclables to the MRF in FY 1993. About 42,500 tons of the recovered materials were sold in FY 1993, 560 tons were disposed of as residue, and 1,040 tons were inventoried. The average net cost of processing and marketing the 43,500 tons of recyclables sold or inventoried was about $\$ 50.80$ per ton (i.e., $\$ 2,207,714$ divided by 43,500 ). The average revenue received for the 42,506 tons of recyclables sold in FY 1993 was about $\$ 15.70$ per ton (i.e., $\$ 665,447$ divided by 42,506$)$.

\subsubsection{Cost of the Compost Operation}

The total cost of the compost operation in FY 1993 was about $\$ 158,700$. Of this amount, the labor cost was $\$ 43,600$, the equipment O\&M cost was $\$ 35,300$, and the equipment capital cost was $\$ 83,600$. These costs were partially offset by revenues of $\$ 3,780$ received from the sale of 5,670 tons of compost. ${ }^{39}$ The City received 8,122 tons of yard waste in FY 1993. The average cost of processing this yard waste was about $\$ 19.50$ per ton (i.e., $\$ 158,700$ divided by 8,122$)^{40}$

${ }^{38}$ The contract assumed a weighted average revenue of $\$ 29.28$ per ton. In FY93 the average revenue actually received was less than $\$ 29.28$; thus, the Commonwealth had to pay the contractor a revenue makeup reflecting the Commonwealth's share (i.e., 65 percent) of the revenue shortfall.

39 Because of the time it takes to produce the compost product from yard waste (i.e., about 7 months), the compost sold in FY93 does not reflect the compost generated from the yard waste collected in FY93.

40 This cost underestimates the average cost of composting yard waste because some of the yard waste (primarily material that required grinding prior to being placed in windrows) collected was stockpiled for processing in FY94. 


\subsubsection{Cost of Disposing of Waste at the Bondi's Island Landfill}

The total FY 1993 O\&M and capital cost of the Bondi's Island Landfill was about $\$ 2,116,800$. Of this amount $\$ 783,600$ (42 percent) was paid to the landfill contractor; $\$ 685,800$ (37 percent) was the capital cost; $\$ 258,600$ (15 percent) was an allowance for closure costs; and $\$ 132 ; 200$ (7 percent) was an allowance for post-closure monitoring. For the 53,970 tons of waste was disposed of at the landfill in FY 1993, this represents an average cost of about $\$ 34.50$ per ton.

The methodology for calculating capital, closure, and post-closure monitoring costs is presented in Section C.1.3 of Appendix C. The capital, closure, and post-closure monitoring costs were calculated based on the volume of waste disposed of in FY 1993. Including an estimated 15 percent, by volume, consumed by cover material, about 63,520 cubic yards of landfill space was consumed. The bulk densities of the wastes disposed of at the landfill are shown in Table 4-4. The FY 1993 average cost of disposal was about $\$ 33.30$ per cubic yard of landfill space consumed, or about $\$ 29.00$ per cubic yard of waste disposed. The average capital, closure, and post-closure monitoring costs were about $\$ 9.40, \$ 3.50$, and $\$ 1.80$ per cubic yard consumed, respectively.

\subsection{Allocation of Costs by Type of Waste}

In the following subsections, the $\$ 9.72$ million gross cost, and the $\$ 7.17$ million net cost of managing the 59,900 tons of Analyzed MSW in FY 1993 are allocated to the cost of managing 44,700 tons of garbage; 7,580 tons of recyclables; 6,810 tons of yard waste; and 807 tons of nonrecyclable bulky waste. Also provided, in subsection 4.5.5, are the allocated costs of managing the 15 tons of HHW. For each type of waste, allocated costs are also broken down by functional area.

The results presented are total allocated costs, i.e., G\&A costs are included in the allocation. ${ }^{41}$ In general, the allocation process followed the following steps: (1) the portion of each expenditure that was applicable to the management of the 59,900 tons of Analyzed MSW was determined; (2) expenses that were dedicated to garbage, recyclables, yard waste, non-recyclable bulky waste, and HHW were identified (e.g., the costs of the HHW collection day contractors were allocated to HHW, etc.); (3) other expenses were allocated based on a number of factors, primarily tonnage, as discussed in Appendix B. Because the DPW's Job Cost data is categorized by type of waste, including the time spent by collection crews, a good portion of the allocations were obtained from the DPW records, as shown in Table C.3 of Appendix C.

G\&A costs that were not specifically allocated to a type of waste through Step 2 above were allocated to each waste type in proportion to the dollar value allocated to each type of waste for all non-G\&A costs. Consequently, the absolute value of the costs attributed to the management of garbage, recyclables, yard waste, non-recyclable bulky waste, and HHW reflect all costs, including G\&A expenses. The slight variations in the percentage of G\&A expenses among the various types of waste occur because some G\&A expenses were allocated exclusively to one or another type of waste.

41 The allocation procedures are provided in Appendix B. 
Table 4-4: Density of Various Types of Waste Disposed of in the Landfill (cubic yards per ton)

Types of Waste

Density

By-Passed Waste

1.70

WTE Facility Ash

1.00

Biosolids (Sludge Compost)

1.90

Sludge

1.20

Street Sweepings

1.90

Catch Basin/Sewer Cleanings

0.70

Grit \& Screenings

0.30

Other

1.00

Source: Springfield DPW, Landfill Capacity Report 


\subsubsection{Cost of Managing Garbage}

The FY 1993 gross and net costs of managing the approximately 44,700 tons of garbage the City collected were approximately $\$ 8.04$ million and $\$ 5.60$ million, respectively. The Average Net Cost of managing these 44,700 tons of garbage was $\$ 125$ per ton.

The allocation by functional area of the gross and net costs is shown in Figure 4-4. Of the $\$ 8.04$ million gross cost, about 57 percent was spent to process garbage at the WTE facility; about 25 percent was spent on collection; about 11 percent was G\&A expenses; about 6 percent was spent to dispose of the ash generated at the WTE facility; and about 1 percent was spent on litter control. Of the $\$ 5.60$ million net cost, about 38 percent was spent to process garbage at the WTE facility; about 36 percent was spent on collection; about 16 percent was G\&A expenses; about 8 percent was spent to dispose of the ash generated at the WTE facility; and about 1 percent was spent on litter control.

\subsubsection{Cost of Managing Recyclables}

The FY 1993 gross and net costs of managing the approximately 7,580 tons of recyclables the City collected were approximately $\$ 1.13$ million and $\$ 1.01$ million, respectively. The Average Net Cost for the 7,440 tons of these recyclables sold, beneficially re-used, or inventoried for future use was $\$ 136$ per ton. This cost includes the costs associated with the curbside recycling program, the white goods collection and recycling program, the office paper recycling program, and the pre-combustion recovery of metals at the WTE facility.

The allocation by functional area of the gross and net costs is shown in Figure 4-5. Of the $\$ 1.13$ million gross cost, about 43 percent was spent on collection; about 41 percent was spent to process recyclables at the MRF; about 16 percent was G\&A expenses; and about 1 percent was spent on other miscellaneous recycling activities (e.g., promotion and education). Of the $\$ 1.01$ million net cost, about 47 percent was spent on collection; about 35 percent was spent to process recyclables at the MRF; about 17 percent was G\&A expenses; and less than 0.1 percent was spent on other miscellaneous recycling activities.

\subsubsection{Cost of Managing Yard Waste}

The City's FY 1993 gross and net costs of managing the approximately 6,810 tons of yard waste it collected were approximately $\$ 381,000$ and $\$ 378,000$, respectively. The Average Net Cost for the 6,810 tons of yard waste converted to compost was $\$ 57$ per ton.

The allocation by functional area of the gross and net costs is shown in Figure 4-6. Of the $\$ 393,000$ gross cost, about 51 percent was spent on collection; about 33 percent was spent to compost the yard waste; and about 16 percent was G\&A expenses. Of the $\$ 390,000$ net cost, about 51 percent was spent on collection; about 33 percent was spent to compost the yard waste; and about 16 percent was G\&A expenses.

\subsubsection{Cost of Managing Non-Recyclable Bulky Waste}

The City's FY 1993 cost of managing the approximately 807 tons of non-recyclable bulky waste it collected was approximately $\$ 159,000$. The Average Cost to manage the 807 tons of non- 
Figure 4-4: Allocation of Total Costs to Manage Garbage

Allocation by Functional Area

(Cost to Manage 44,700 Tons of Analyzed Garbage)

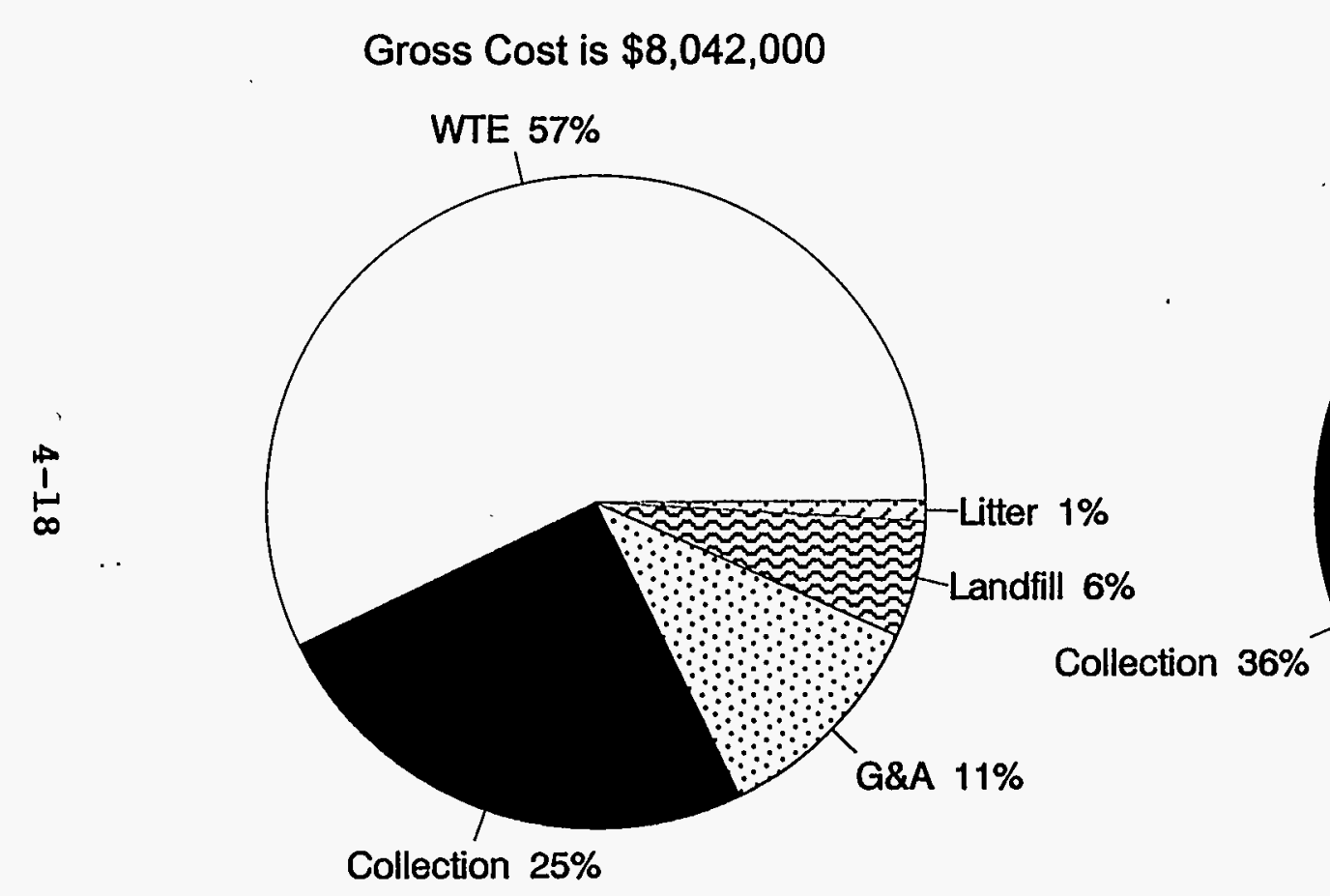

Net Cost is $\$ 5,600,000$

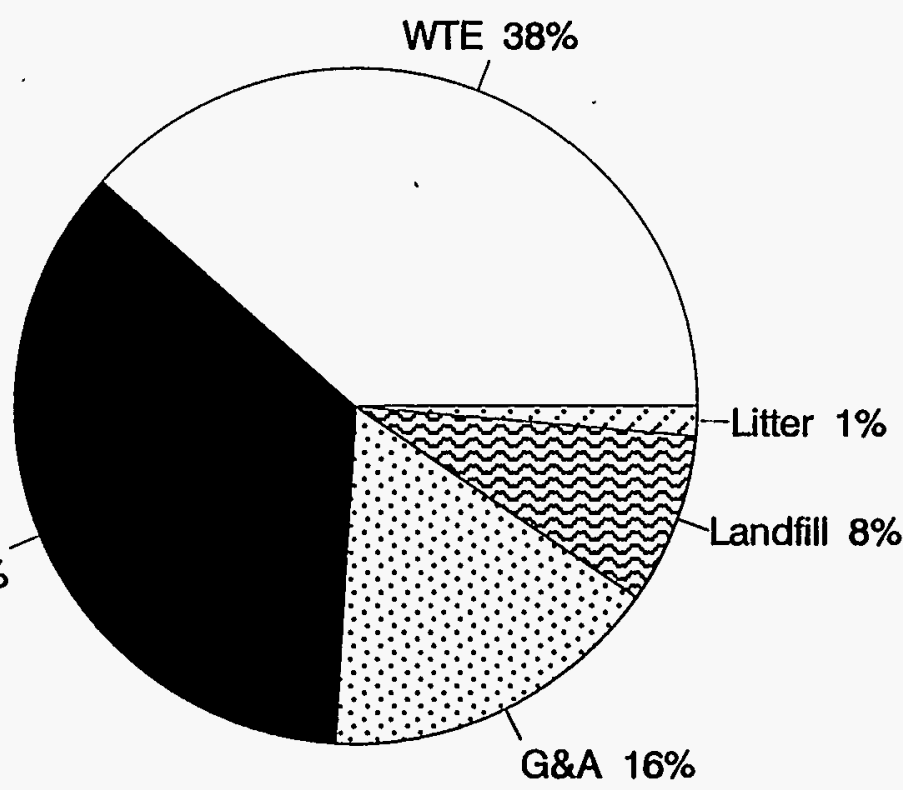




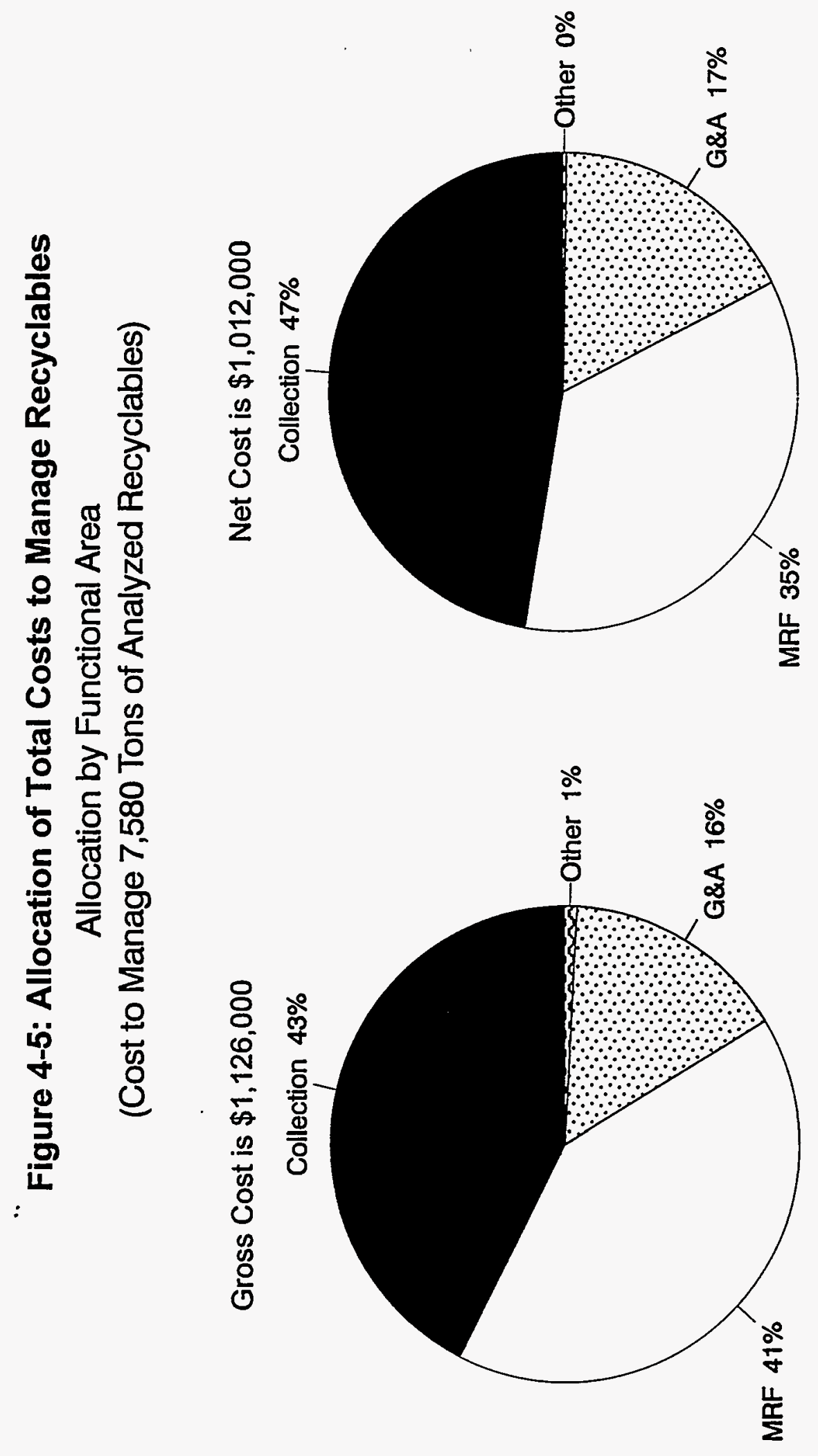

4-19 
Figure 4-6: Allocation of Total Costs to Manage Yard Waste

Allocation by Functional Area

(Cost to Manage 6,810 Tons of Analyzed Yard Waste)
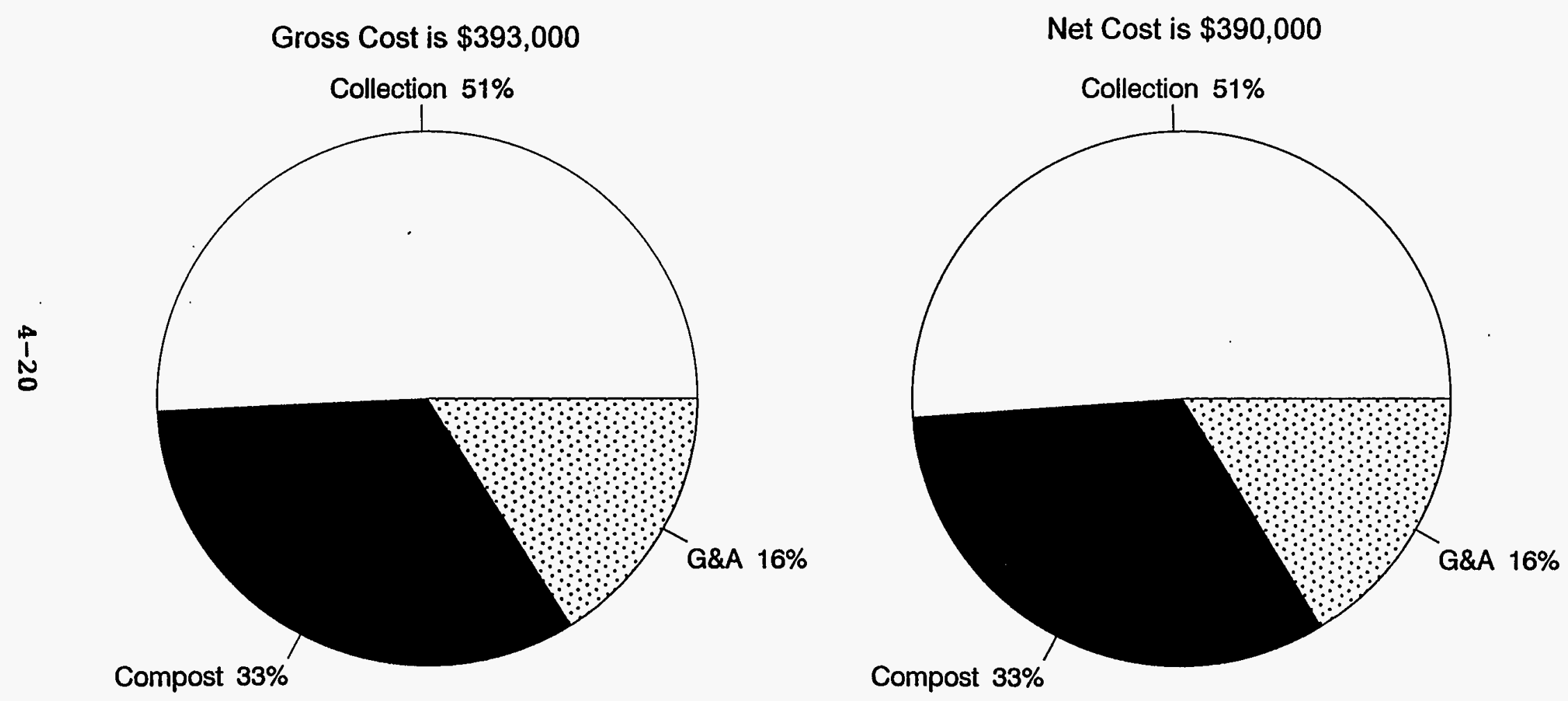
recyclable bulky waste was $\$ 197$ per ton.

The allocation by functional area of the cost is shown in Figure 4-7. Of the $\$ 159,000$ cost, about 50 percent was spent on collection; about 34 percent was spent to landfill the bulky waste; and about 16 percent was G\&A expenses.

\subsubsection{Cost of Managing HHW}

The City's FY 1993 cost of managing the approximately 15 tons of HHW was approximately $\$ 33,600$. The allocation by functional area of this cost is shown in Figure 4-8. Of the $\$ 33,600$ cost, about 84 percent was spent on collection, processing, and disposal; and 16 percent was G\&A expenses.

\subsection{Program Incremental Costs}

In this section the estimated Program Incremental Cost of the WTE facility and the curbside recycling, yard waste composting, white goods recycling, and office paper recycling programs are presented. A Program Incremental Cost (or Savings) is defined as "the difference between the cost of managing MSW with and without the inclusion of a particular program." Each Program Incremental Cost presented below reflects FY 1993 price levels and contractual relationships and can be interpreted as the FY 1993 cost or savings of a particular program.

The results of the Program Incremental Cost analysis are provided in Table 4-5 through 4-9 . Each table shows in the first column the cost incurred by the City in FY 1993, which includes the net cost of all the resource recovery programs (i.e., "With Program"). The second column of each table (i.e., "Without Program") shows the estimated net G\&A, collection, MRF, WTE, compost operation, white good preparation, miscellaneous recycling (including promotion and education expenses), and landfill expenses and revenues that would have occurred if a given program had never been implemented. Some costs that are unaffected by a program are excluded from the analysis (i.e., the difference with and without the program is zero). The difference, i.e., the Program Incremental Cost (or Savings), is provided in the third column. The sum of these incremental costs are rounded to the nearest hundred dollars to emphasize that these costs are estimates and not actual reported costs.

Detailed discussion of the data, methodology, and assumptions used to estimate these Program Incremental Costs is provided in Section C. 2 of Appendix C.

\subsubsection{Waste-to-Energy Program}

The FY 1993 estimated Program Incremental Cost for the Waste-to-Energy Program is about $\$ 322,500$, or $\$ 7$ per ton for the 45,677 tons of City waste combusted at the Facility. Table $4-5$ shows costs with and without the WTE Program and the incremental cost for various cost categories.

The 45,677 tons consists of the 44,707 tons of MSW collected by the Solid Waste Division and delivered to the Facility plus 970 tons of waste brought to the Facility by other City Departments (e.g., Public Housing, Parks, and Wastewater Treatment). This additional 970 tons is included in the incremental cost analysis because the City would have to landfill this waste if there were 


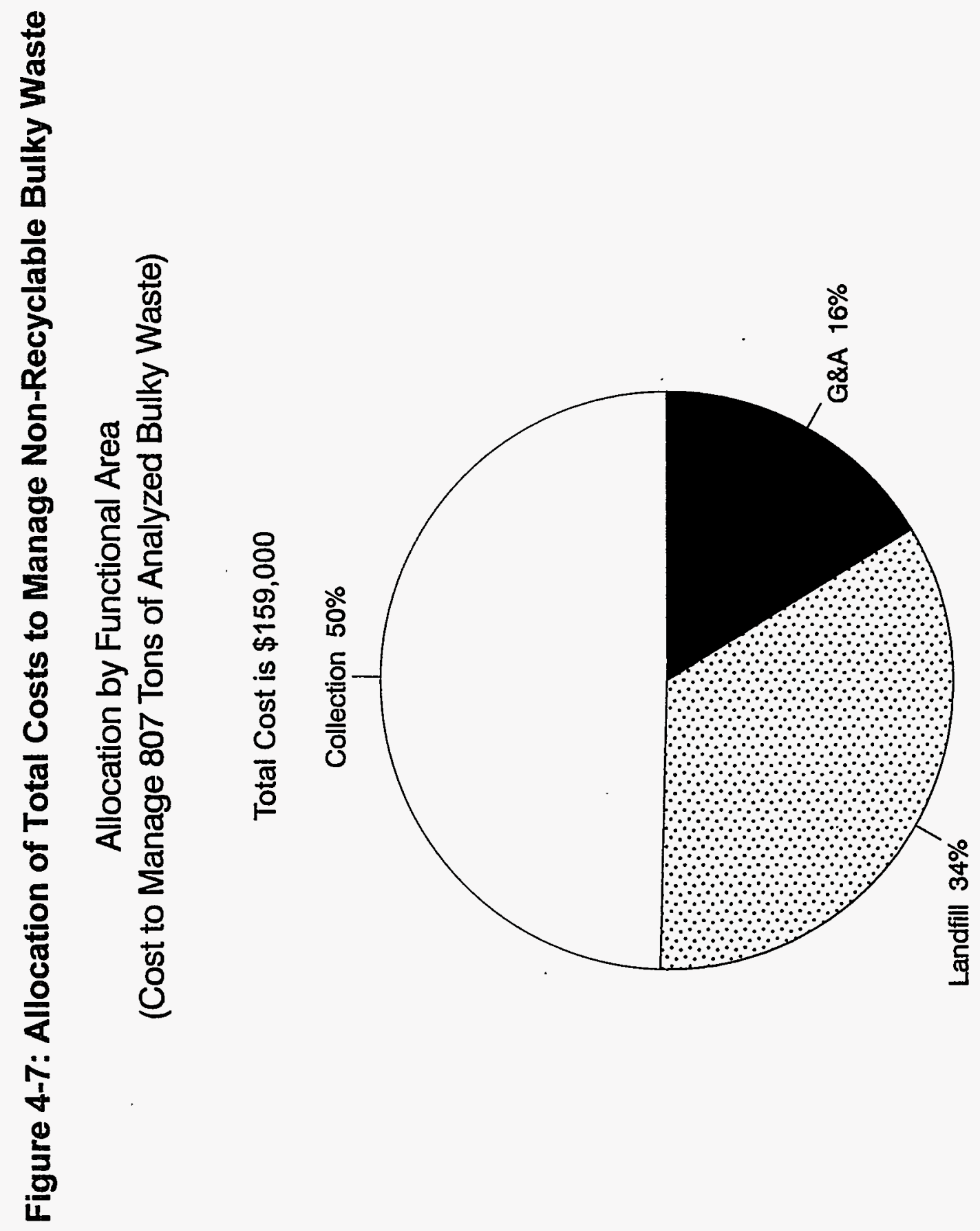


Figure 4-8: Allocation of Total Costs to Manage HHW

Allocation by Functional Area

(Cost to Manage 15 Tons of HHW)

Total Cost is $\$ 33,600$

$\stackrel{+}{1}$

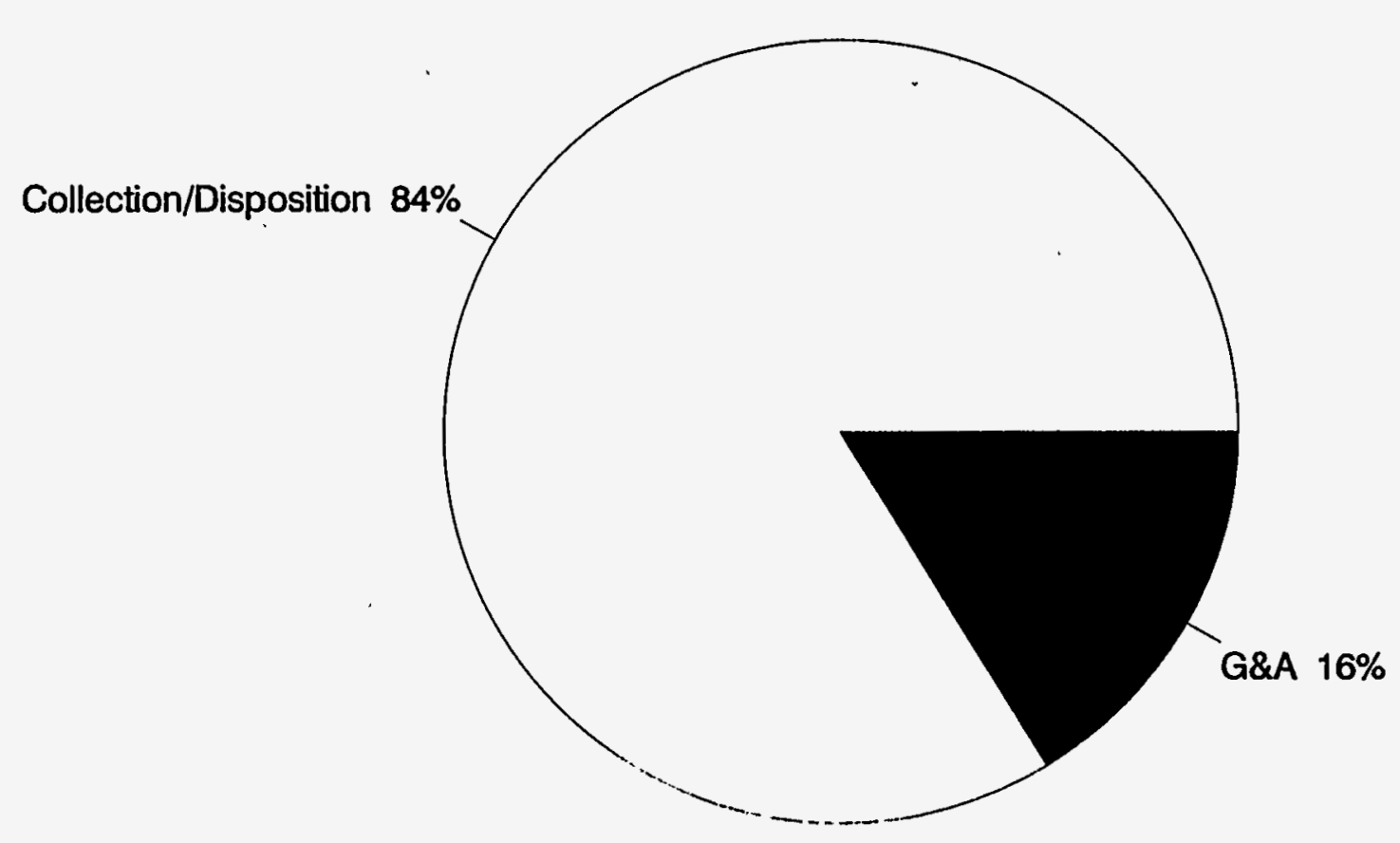


Table 4-5: Incremental Cost of the Waste-to-Energy Program (dollars)

Cost Categories

and Revenues

With
Program

With
Program
Without

Program
Incremental

Cost

(Savings)
General \& Administration

Collection

Materials Recovery Facility

Waste-to-Energy Facility

Composting Operation

White Goods Preparation

Miscellaneous Recycling

Landfill

Revenues

Total
$1,180,034$

$2,763,585$

461,036

$4,589,018$

130,318

3,831

4,083

646,325

$(2,554,760)$

$7,223,470$
$1,118,609$

$2,763,585$

461,036

0

130,318

3,831

4,083

$2,536,580$

$(117,080)$

$6,900,962$
61,425

0

0

$4,589,018$

0

0

0

$(1,890,256)$

$(2,437,680)$

322,500

Tons Managed 45,677

Incremental Cost per Ton

Note: Tons Managed is equal to 44,707 tons of MSW plus 970 tons of waste from other City divisions. 
no waste-to-energy facility. On the other hand, this analysis does not consider the incremental costs (or savings) that are incurred by the other communities using the WTE Facility. ${ }^{42}$

The estimation of the WTE Program Incremental Cost assumes that all the MSW delivered to the WTE Facility by the City in FY 1993 would have been disposed of at the Bondi's Island landfill if there were no WTE Facility. Another important assumption is that if there were no WTE Facility, then the fixed and variable fees paid the landfill contractor for operating the landfill would be those paid in FY 1993. To test this assumption CSI estimated the cost to operate and maintain the landfill without the WTE Facility. CSI concluded from this analysis that the current landfill fees would be sufficient to cover the O\&M costs of disposing of 45,677 tons of MSW at the landfill and a reasonable profit for the operator. ${ }^{43}$

The $\$ 322,500$ WTE Program Incremental Cost is comprised of $\$ 61,420 \mathrm{G \& A}$ and $\$ 4.59$ million WTE Facility incremental costs which is partially offset by $\$ 1.89$ million landfill and $\$ 2.44$ million revenue incremental savings. The WTE Facility incremental cost is the City's share of the service fee paid to the WTE Facility operator while the revenues are the steam and electricity revenues generated from the combustion of the City's MSW. The incremental landfill savings is the avoided landfill operator fees and the landfill capital, closure, and post-closure monitoring costs.

\subsubsection{Curbside Recvcling Program}

The FY 1993 estimated Program Incremental Cost for the Curbside Recycling Program is $\$ 774,500$, or $\$ 111$ per ton for the 6,958 tons of City collected materials that were recycled. Table 4-6 shows costs with and without the Curbside Recycling Program and the incremental cost for various cost categories.

The 6,958 tons is equal to the 7,048 tons of recovered materials collected by the City less 90 tons of the associated residue generated at the MRF. This analysis does not consider the incremental cost (or savings) that would be incurred by the other communities using the MRF. ${ }^{44}$

The estimation of the Curbside Recycling Program Incremental Cost assumes that if there were no Curbside Recycling Program, then all of the City's recovered materials delivered to the MRF in FY 1993 would have been brought to the WTE Facility. This is a reasonable assumption because most of the material recovered consisted of combustible material (e.g., paper and plastic). Another assumption is that the MRF would not have been built. This assumption implies that the

42 Inclusion of the incremental costs to all communities that use the WTE Facility is beyond the scope of this study.

${ }^{43}$ CSI uses its "MSW Management Assessment Model," Landfill Submodel, 1994 to make this landfill cost assessment.

44 Inclusion of the incremental costs for the 90 plus communities that use the MRF is beyond the scope of this study. 
Table 4-6: Incremental Cost of the Curbside Recycling Program (dollars)

\begin{tabular}{lrrr}
\hline $\begin{array}{l}\text { Cost Categories } \\
\text { and Revenues }\end{array}$ & \multicolumn{1}{c}{$\begin{array}{c}\text { With } \\
\text { Program }\end{array}$} & \multicolumn{1}{c}{$\begin{array}{c}\text { Without } \\
\text { Program }\end{array}$} & \multicolumn{1}{c}{$\begin{array}{c}\text { Incremental } \\
\text { Cost } \\
\text { (Savings) }\end{array}$} \\
\hline General \& Administration & $1,180,034$ & $1,118,609$ & 61,425 \\
Collection & $2,763,585$ & $2,354,001$ & 409,584 \\
Materials Recovery Facility & 461,036 & 0 & 461,036 \\
Waste-to-Energy Facility & $4,589,018$ & $4,589,018$ & 0 \\
Composting Operation & 130,318 & 130,318 & 0 \\
White Goods Preparation & 3,831 & 3,831 & 0 \\
Miscellaneous Recycling & 4,083 & 4,083 & 0 \\
Landfill & 512,297 & 563,257 & $(50,960)$ \\
Revenues & $(2,554,760)$ & $(2,448,176)$ & $(106,584)$ \\
\hline Total & $7,089,442$ & $6,314,941$ & 774,500 \\
\hline Tons Managed & & & \\
Incremental Cost per Ton & & & 6,958 \\
\hline
\end{tabular}


MRF incremental cost attributed to the City is equal to the City's share of the MRF costs. ${ }^{45}$

The $\$ 774,500$ Curbside Recycling Program Incremental Cost is comprised of $\$ 61,420$ G\&A, $\$ 409,580$ Collection, and $\$ 461,040 \mathrm{MRF}$ incremental costs which is partially offset by $\$ 50,960$ landfill and $\$ 106,580$ revenue incremental savings. The MRF incremental cost is the portion of the G\&A, contractor service fee and capital costs paid by the Commonwealth for the MRF while the revenues are the revenues generated from the sale of recovered materials attributed to the materials collected by the City's. The incremental landfill savings is the avoided landfill operator fees and the landfill capital, closure, and post-closure monitoring costs for the disposal of the ash that would have been generated if this material was combusted at the WTE Facility.

In FY 1993 the City paid the WTE operator for the disposal of 58,040 tons of MSW, but only was able to deliver 45,677 tons, i.e., the City did not meet its put-or-pay commitment of 58,040 tons. Therefore, although the Curbside Recycling Program resulted in the divergence of 7,048 tons of material from the WTE Facility it did not result in any reduction in the fees paid to the operator, i.e., there was no incremental savings at the WTE Facility.

If the City had met its put-or-pay commitment, then the maximum excess tonnage fee paid would have been $\$ 15.90$ per ton, or $\$ 122,060 .^{46}$ Thus, if the City had met its put-or-pay commitment and had to pay the maximum excess tonnage fee, then the incremental cost of the Curbside Recycling Program would have been $\$ 661,000$, or $\$ 95 /$ ton.

\subsubsection{Yard Waste Composting Program}

The FY 1993 estimated Program Incremental Cost for the Yard Waste Composting Program is $\$ 274,000$, or $\$ 36$ per ton for the 7,515 tons of City yard waste that was composted. Table 4-7 shows costs with and without the Yard Waste Composting Program and the incremental cost for various cost categories.

The 7,515 tons is equal to the sum of 6,814 tons of yard waste collected at the curb by the City, 337 tons of yard waste collected from street sweeping operations, and 364 tons of yard waste that was self-hauled by City residents. ${ }^{47}$ If there were no yard waste composting operation the City would have to still manage the street sweepings and self-hauled yard waste, therefore, these wastes are included in the incremental analysis. On the other hand, this analysis does not consider the incremental costs (or savings) that are incurred by the City of Agawam. ${ }^{48}$

45 An alternative assumption would be that one or more smaller MRFs would have been built to service the other communities in the Pioneer Valley.

46 In FY93 the excess tonnage fee was equal to the lessor of $\$ 15.90$ per ton or the actual average service fee then in effect. (See Section 6.4(f) of "Springfield Resource Recovery Project," Restated Solid Waste Disposal Service Agreement, July 1, 1986.)

47 The incremental collection cost does not include the incremental costs incurred by residents to self-haul yard waste to Bondi's Island. Therefore, the incremental cost present here are understated.

48 Inclusion of the incremental cost for Agawam is beyond the scope of this study. 
Table 4-7: Incremental Cost of the Yard Waste Composting Program (dollars)

\begin{tabular}{|c|c|c|c|}
\hline $\begin{array}{l}\text { Cost Categories } \\
\text { and Revenues }\end{array}$ & $\begin{array}{l}\text { With } \\
\text { Program }\end{array}$ & $\begin{array}{l}\text { Without } \\
\text { Program }\end{array}$ & $\begin{array}{c}\text { Incremental } \\
\text { Cost } \\
\text { (Savings) }\end{array}$ \\
\hline General \& Administration & $1,180,034$ & $1,180,034$ & 0 \\
\hline Collection (a) & $2,771,670$ & $2,616,501$ & 155,169 \\
\hline Materials Recovery Facility & 461,036 & 461,036 & 0 \\
\hline Waste-to-Energy Facility & $4,589,018$ & $4,589,018$ & 0 \\
\hline Composting Operation & $147 ; 556$ & 0 & 147,556 \\
\hline White Goods Preparation & 3,831 & 3,831 & 0 \\
\hline Miscellaneous Recycling & 4,083 & 4,083 & 0 \\
\hline Landfill & 512,297 & 537,393 & $(25,096)$ \\
\hline Revenues & $(2,555,086)$ & $(2,551,585)$ & $(3,501)$ \\
\hline Total & $7,114,439$ & $6,840,311$ & 274,000 \\
\hline Tons Managed & & & 7,515 \\
\hline Incremental Cost per Ton & & & 36 \\
\hline
\end{tabular}

(a) Collection cost does not include the cost incurred by residents to self-haul yard waste to the Bondi's

Island. Therefore, the incremental cost is understated. 
The estimation of the Yard Waste Composting Program Incremental Cost assumes that if there were no Yard Waste Composting Program, then all of the City's yard waste delivered to the composting site in FY 1993 would have been brought to the WTE Facility.

The $\$ 274,000$ Yard Waste Composting Program Incremental Cost is comprised of $\$ 155,170$ Collection, and $\$ 147,560$ Composting Operation incremental costs which is partially offset by $\$ 25,100$ landfill and $\$ 3,500$ revenue incremental savings. The incremental landfill savings is the avoided landfill operator fees and the landfill capital, closure, and post-closure monitoring costs for the disposal of the ash that would have been generated if this yard waste was combusted at the WTE Facility.

As stated previously, the City did not meet its put-or-pay commitment at the WTE Facility in FY 1993. Therefore, although the Yard Waste Composting Program resulted in the divergence of 7,515 tons of material from the WTE Facility it did not result in any reduction in the fees paid to the operator, i.e., there was no incremental savings at the WTE Facility. If the City had met its put-or-pay commitment, then the maximum excess tonnage fee it would have paid would have been $\$ 15.90$ per ton, or $\$ 119,490$. Thus, if the City had met its put-or-pay commitment and had to pay this maximum excess tonnage fee, then the incremental cost of the Yard Waste Composting Program would have been $\$ 155,000$, or $\$ 21 /$ ton.

\subsubsection{Office Paper Recycling Program}

The FY 1993 estimated Program Incremental Cost for the Office Paper Recycling Program is about $\$ 1,500$, or $\$ 68$ per ton for the 22 tons of office paper collected by the City. Table 4-8 shows costs with and without the Office Paper Recycling and the incremental cost for various cost categories. The estimation of the Office Paper Recycling Program Incremental Cost assumes that if there were no Office Paper Recycling Program, thenall of the office paper delivered to the MRF in FY 1993 would have been brought to the WTE Facility.

The $\$ 1,500$ Office Paper Recycling Program Incremental Cost is comprised of $\$ 910$ Collection and $\$ 870 \mathrm{MRF}$ incremental costs which is partially offset by $\$ 90$ landfill and $\$ 200$ revenue incremental savings. The incremental landfill savings is the avoided landfill operator variable fees and the landfill capital, closure, and post-closure monitoring costs for the disposal of the ash that would have been generated if this office paper was combusted at the WTE Facility.

Because the City did not meet its put-or-pay commitment at the WTE Facility in FY 1993, there was no incremental savings at the WTE Facility. If the City had met its put-or-pay commitment, then the maximum excess tonnage fee it would have paid would have been $\$ 15.90$ per ton, or $\$ 350$. Thus, if the City had met its put-or-pay commitment and had to pay this maximum excess tonnage fee, then the incremental cost of the Office Paper Recycling Program would have been $\$ 1,100$, or $\$ 50 /$ ton.

\subsubsection{White Goods Recycling Program}

The FY 1993 estimated Program Incremental Savings for the White Goods Recycling Program 
Table 4-8: Incremental Cost of the Office Wastepaper Recycling Program (dollars)

\begin{tabular}{lrrr}
\hline $\begin{array}{l}\text { Cost Categories } \\
\text { and Revenues }\end{array}$ & $\begin{array}{c}\text { With } \\
\text { Program }\end{array}$ & $\begin{array}{c}\text { Without } \\
\text { Program }\end{array}$ & $\begin{array}{c}\text { Incremental } \\
\text { Cost } \\
\text { (Savings) }\end{array}$ \\
\hline General \& Administration & $1,180,034$ & $1,180,034$ & 0 \\
Collection & $2,763,585$ & $2,762,679$ & 906 \\
Materials Recovery Facility & 461,036 & 460,162 & 874 \\
Waste-to-Energy Facility & $4,589,018$ & $4,589,018$ & 0 \\
Composting Operation & 130,318 & 130,318 & 0 \\
White Goods Preparation & 3,831 & 3,831 & 0 \\
Miscellaneous Recycling & 4,083 & 4,083 & $(89)$ \\
Landfill & 512,297 & 512,386 & $(196)$ \\
Revenues & $(2,554,760)$ & $(2,554,564)$ & 1,500 \\
Total & $7,089,442$ & $7,087,946$ & 22, \\
\hline Tons Managed & & & 68 \\
\hline Incremental Cost per Ton & & & \\
\hline
\end{tabular}


is about $\$ 41,300$, or $\$ 81$ per ton for the 509 tons of white goods collected by the City. ${ }^{49}$ Table 4-9 shows costs with and without the White Goods Recycling Program and the incremental cost for various cost categories.

The estimation of the Program Incremental Savings of the White Goods Recycling Program assumes that if there were no White Goods Recycling Program the City would bring them to the Chicopee landfill for processing (e.g., removal of CFCs) and disposal. It is further assumed that the incremental haul cost (i.e., haul to the Chicopee landfill rather than to the Bondi's Island landfill is minimal.

The $\$ 41,300$ White Goods Recycling Program Incremental Savings is comprised of $\$ 34,200$ landfill and $\$ 7,100$ revenue incremental savings.

49 Of the 509 tons collected about 433 tons of metals and plastics (i.e., 85 percent of 509) are recovered for recycling. The average incremental savings for the materials recovered was $\$ 95$ per ton (i.e., $\$ 41,300$ divided by 433 ). 
Table 4-9: Incremental Cost of the White Goods Recycling Program (dollars)

\begin{tabular}{lrrr}
$\begin{array}{l}\text { Cost Categories } \\
\text { and Revenues }\end{array}$ & $\begin{array}{c}\text { With } \\
\text { Program }\end{array}$ & $\begin{array}{c}\text { Without } \\
\text { Program }\end{array}$ & $\begin{array}{c}\text { Incremental } \\
\text { Cost } \\
\text { (Savings) }\end{array}$ \\
\hline General \& Administration & $1,180,034$ & $1,180,034$ & 0 \\
Collection & $2,763,585$ & $2,763,585$ & 0 \\
Materials Recovery Facility & 461,036 & 461,036 & 0 \\
Waste-to-Energy Facility & $4,589,018$ & $4,589,018$ & 0 \\
Composting Operation & 130,318 & 130,318 & 0 \\
White Goods Preparation & 3,831 & 3,831 & 0 \\
Miscellaneous Recycling & 4,083 & 4,083 & $(34,164)$ \\
Landfill & 512,297 & 546,461 & $(7,126)$ \\
Revenues & $(2,554,760)$ & $(2,547,634)$ & $(41,300)$ \\
Total & $7,089,442$ & $7,130,732$ & 509 \\
\hline Tons Managed & & & \\
Incremental Cost per Ton & & & $(81)$ \\
\hline
\end{tabular}




\section{Energy Usage Analysis}

The energy consumed to manage MSW in Springfield during FY 1993 is discussed in this section. The forms of energy used within Springfield's IMSWM System are gasoline, diesel fuel, propane, number 2 fuel oil, and electricity. The energy is consumed by collection vehicles, the WTE facility, the MRF, the yard waste composting operation, the white goods processing operation, the Bondi's Island Landfill, and the transfer vehicles used for hauling recyclables to market. The quantity of energy, i.e., steam and electricity, generated for sale by the WTE facility is presented in Section 5.6.5

\subsection{Summary of Results}

In FY 1993, the Springfield IMSWM System configuration resulted in the consumption of the equivalent of approximately 670,000 gallons of diesel fuel. Almost 80 percent of this energy was for the processing of MSW at the resource recovery facilities. This energy consumption was offset by about 1.16 million equivalent gallons of diesel fuel conserved as a result of the net energy produced by the WTE facility. Thus, on a net basis, the Springfield IMSWM System resulted in the conservation of the equivalent of approximately 500,000 gallons of diesel fuel.

As shown in Table 5-1, there were significant differences among the per-ton energy consumptions for managing the various categories of MSW. However, without taking into account the energy produced at the WTE, energy consumption for managing garbage and curbside recyclables was similar (5.2 and 4.5 gallons/ton, respectively).

\subsection{Collection Vehicle Energy Consumption}

Data on the fuel consumed by the collection vehicles is provided in Table 5-2. Some vehicles use gasoline, others use diesel fuel as shown in Table 5-3. The fuel consumption data for the various types of vehicles was provided by the City's DPW. ${ }^{51}$

Because the energy content per gallon of gasoline, measured in British Thermal Units (Btus), is less than that of diesel fuel, the use of a gallon of gasoline consumes less energy than the use of a gallon of diesel fuel. For this reason gasoline consumption is converted to equivalent gallons of diesel fuel (on a Btu basis) by multiplying the gallons of gasoline by the ratio of the Btu content of the gasoline to the Btu content of diesel fuel (i.e., 127,650/146,390). ${ }^{52}$

so Since this study only evaluates the energy consumption and production for the Springfield IMSWM System, the energy consumed or conserved at the remanufacturing facilities that process recyclables is not included.

${ }^{51}$ DPW, "Determination of Fiscal Year 1993 Total Costs for Various Solid Waste Programs," Computer Printout, August 20, 1993, and Memo from Jack Dowd, Deputy Director, Public Works to Dennis Akins, September 15, 1993.

52 According to Marks Standard Handbook for Mechanical Engineers, 8th Edition, McGraw Hill Publishers, the energy content of gasoline is about $20,750 \mathrm{Btu} / \mathrm{lb}$. At 6.152 pounds per gallon, the Btu per gallon is 127,650 . Similarly, the energy content of diesel fuel is about $18,400 \mathrm{Btu} / \mathrm{lb}$. At 7.956 pounds per gallon the Btu content per gallon is about 146,390 . 
Table 5-1: Energy Consumption on a Per-Gallon Equiblalent Basis (equivalent gallons/ton)

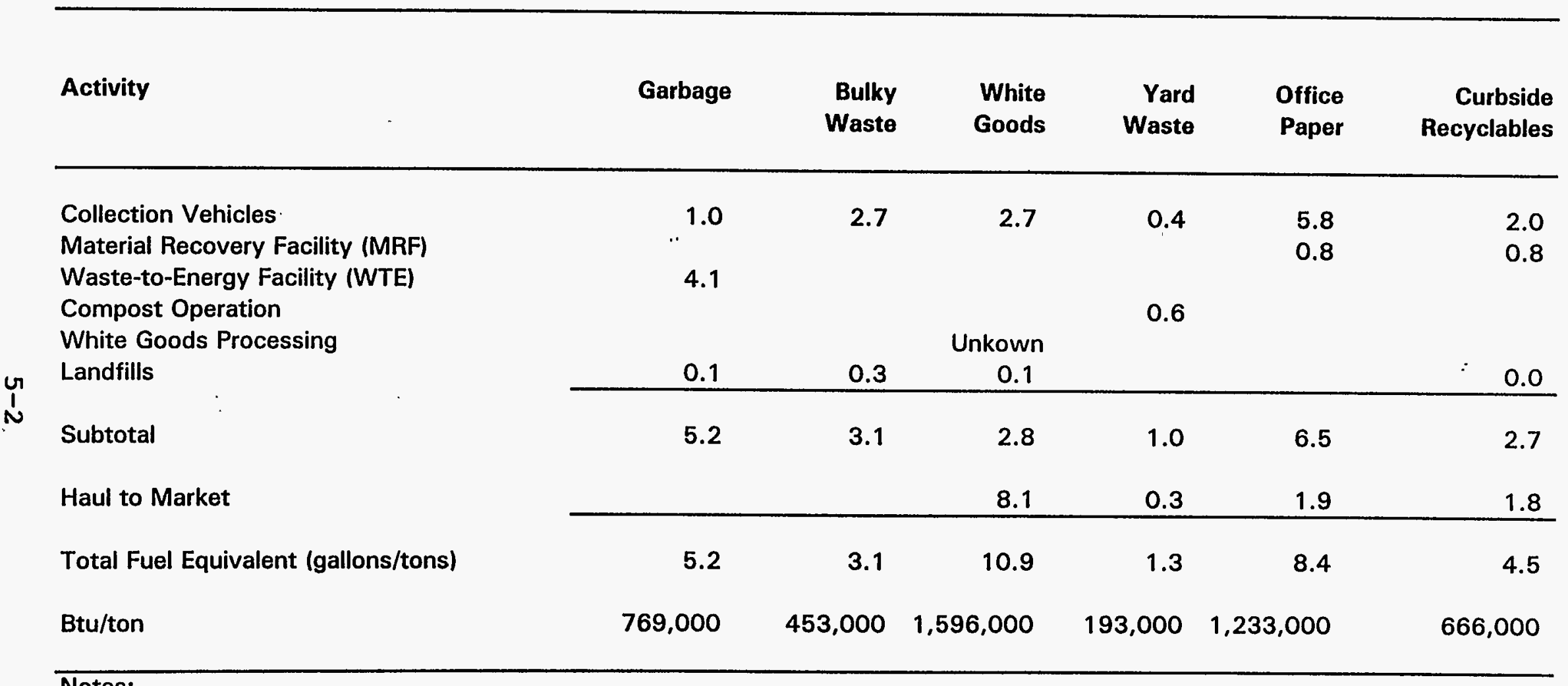

\section{Notes:}

a. For each ton of garbage collected and combusted at the WTE facility, about 25.5 equivalent gallons of diesel fuel (3.5 million Btus) were conserved. 
Table 5-2: Energy Consumption to Collect Garbage, Bulky Waste, Office Paper, and Recyclables in Springfield

\begin{tabular}{|c|c|c|c|c|c|}
\hline Variables & Garbage & $\begin{array}{l}\text { Bulky } \\
\text { Waste }\end{array}$ & $\begin{array}{r}\text { Yard } \\
\text { Waste }\end{array}$ & $\begin{array}{l}\text { Office } \\
\text { Paper }\end{array}$ & Recyclables \\
\hline Tons Collected & 44,707 & 1,316 & 6,814 & 22 & 7,048 \\
\hline Diesel Fuel Consumed (gallons) & 46,598 & 3,617 & 3,061 & 127 & 14,017 \\
\hline Millions of Btus & 6,820 & 530 & 450 & 20 & 2,050 \\
\hline Gallons per Ton & 1.0 & 2.7 & 0.4 & 5.8 & 2.0 \\
\hline
\end{tabular}

w Note: Conversion to millions of Btus assumes 146,390 Btus per gallon.

Source: City of Springfield - DPW, "Determination of Fiscal Year 1993 Total Costs for Various

Solid Waste Programs," Computer Printout, August 20, 1993. 
Table 5-3: Vehicles and Equipment Fuel Consumption Data

\begin{tabular}{|c|c|c|c|c|c|}
\hline $\begin{array}{l}\text { Vehicle } \\
\text { ID No. }\end{array}$ & Make & $\begin{array}{l}\text { Model } \\
\text { Year }\end{array}$ & $\begin{array}{l}\text { Fuel } \\
\text { Type }\end{array}$ & $\begin{array}{c}\text { Gallons/ } \\
\text { Year }\end{array}$ & $\begin{array}{l}\text { Eq. Gal./ } \\
\text { Year }\end{array}$ \\
\hline \multicolumn{6}{|c|}{ GARBAGE/YARD WASTE } \\
\hline 331 & Mack/Leach & 1984 & Diesel & & \\
\hline 332 & Mack/Leach & 1984 & Diesel & & \\
\hline 333 & Mack/Leach & 1984 & Diesel & & \\
\hline 334 & Mack/Leach & 1984 & Diesel & & \\
\hline 335 & Mack/Leach & 1984 & Diesel & & \\
\hline 336 & Mack/Leach & 1984 & Diesel & & \\
\hline 337 & Mack/Leach & 1984 & Diesel & & \\
\hline 338 & Mack/Leach & 1984 & Diesel & & \\
\hline 339 & Mack/Leach & 1984 & Diesel & & \\
\hline 340 & Mack/Leach & 1984 & Diesel & & \\
\hline 341 & Mack/Leach & 1984 & Diesel & & \\
\hline 342 & Mack/Leach & 1984 & Diesel & & \\
\hline 343 & Mack/Leach & 1989 & Diesel & & \\
\hline 344 & Mack/Leach & 1989 & Diesel & & \\
\hline 308 & Diamond Reo & 1974 & Gas. & 879 & 766 \\
\hline \multicolumn{2}{|c|}{ RBAGE/YARD WASTE } & & & $47,360(a)$ & $47,247(a)$ \\
\hline \multicolumn{6}{|c|}{ ECYCLABLES } \\
\hline 371 & Labrie & . 1990 & Diesel & 1,512 & 1,512 \\
\hline 372 & Loadall & 1990 & Diesel & 1,812 & 1,812 \\
\hline 373 & Loadall & 1990 & Diesel & 2,040 & 2,040 \\
\hline 374 & Loadall & 1990 & Diesel & 2,028 & 2,028 \\
\hline 375 & Loadall & 1990 & Diesel & 2,016 & 2,016 \\
\hline 376 & Loadall & 1991 & Diesel & 2,124 & 2,124 \\
\hline 377 & Labrie & 1992 & Diesel & 1,968 & 1,968 \\
\hline 378 & Labrie & 1990 & Diesel & 517 & 517 \\
\hline L RECYCLA & LES & & & 14,017 & 14,017 \\
\hline \multicolumn{6}{|c|}{ ULKY WASTE } \\
\hline 311 & Diamond Reo & 1975 & Gas & 1,562 & 1,362 \\
\hline 324 & Mack & 1988 & Diesel & 2,255 & 2,255 \\
\hline TOTAL OBV & - & & & 3,817 & 3,617 \\
\hline \multicolumn{6}{|c|}{ WHITE PAPER/LITTER } \\
\hline 395 & Diamond Reo & 1971 & Gas & 2,912 & 2,539 \\
\hline \multicolumn{6}{|c|}{ COMPOST OPERATIION \& SNOW REMOVAL } \\
\hline 276 & Ford Dump Truck & 1988 & Diesel & 1,642 & 1,642 \\
\hline 437 & Front End Loader & 1986 & Diesel & 1,086 & 1,086 \\
\hline 573 & SCARAB & 1989 & Diesel & 1,978 & 1,978 \\
\hline 574 & Yard Waste Ginder & 1993 & Diesel & & \\
\hline \multicolumn{4}{|c|}{ TOTAL COMPOST/SNOW } & 4,706 & 4,706 \\
\hline
\end{tabular}

(a) Vehicle \#308 was the only garbage/yard waste vehicle for which individual fuel consumption data was provided. 
About 46,481 gallons of diesel fuel were consumed by 14 garbage/yard waste collection vehicles in FY 1993. The DPW reported that $69,502.2$ labor hours were spent collecting garbage and 4,999.5 labor hours were spent collecting yard waste. Assuming that these hours reflect the time the garbage/yard waste vehicles spent collecting each type of waste, then 93.4 percent of the time they were used to collect garbage. Thus, an estimated 43,400 gallons of diesel fuel were used to collect garbage. Vehicle $30 \dot{8}$ was also used to collect garbage in FY 1993 and consumed 766 equivalent gallons of diesel fuel. Vehicle 395 was used to collect office white paper about 5 percent of the time (i.e., about 2 hours per week) ${ }^{33}$ and to pick up garbage from litter barrels located throughout the City about 95 percent of time. About 2,410 equivalent gallons (i.e., 2,539 times 0.95 ) consumed by vehicle 395 is attributable to the collection of garbage. In total, about 46,600 equivalent gallons (i.e., $43,400+766+2,410$ ) were consumed to collect 44,707 tons of garbage in FY 1993. This reflects an average rate of 1.0 gallons per ton.

Two vehicles were used to collect bulky wastes, including white goods. One used gasoline and the other used diesel fuel. The equivalent diesel fuel consumption for both these vehicles was 3,617 gallons (see Table 5-3). Given that 1,316 tons of bulky waste were collected in FY 1993, about 2.7 equivalent gallons of diesel fuel were consumed per ton of bulky waste, including white goods, collected.

As indicated above, 46,481 gallons of diesel fuel were consumed by 14 garbage/yard waste collection vehicles in FY 1993. These vehicles were used about 6.6 percent (i.e., 1.00 minus 0.934) of the time to collect yard waste. Thus, about 3,060 gallons of diesel fuel were used to collect yard waste. This reflects an average fuel consumption of 0.4 gallons per ton to collect 6,814 tons of yard waste.

Vehicle 395 was used about 2 hours a week to collect office paper from City office buildings. For the remainder of the week this vehicle was used to collect garbage from litter containers located throughout the City. About 5 percent (i.e., 2 divided by 40 ) of the fuel consumed by this vehicle was for the collection of office paper. This vehicle consumed 127 equivalent gallons of diesel fuel (i.e., 2,539 times .05) to collect 22 tons of office paper. This reflects an average fuel consumption of 5.8 gallons per ton.

The eight vehicles used to collect recyclables consumed 14,017 gallons of diesel fuel, or an average rate of 2.0 gallons per ton, to collect 7,048 tons of recyclables. ${ }^{54}$

\subsection{Energy Consumption at the MSW Processing and Disposal Facilities}

The energy consumed at the WTE facility, MRF, yard waste composting operation, white goods bailing operation, and Bondi's Island landfill are shown in Table 5-4. The energy consumption data for the WTE facility, MRF, and landfill were provided by Springfield Resource Recovery,

53 Telephone discussion with Mr. Michael Triggs, DPW, June 1994.

${ }^{54}$ As is the case for average costs, it is inappropriate to compare average fuel consumptions and make conclusions about the incremental energy consumption of a given program. Rather, to estimate the incremental energy consumption of a given program, an estimate of total energy consumed without the program would have to be compared to the energy consumption with the program. 
Table 5-4: Energy Consumption by Function

\begin{tabular}{lrrrr}
\hline Function & $\begin{array}{r}\text { Diesel } \\
\text { Fuel } \\
\text { (gallons) }\end{array}$ & $\begin{array}{r}\text { No. 2 } \\
\text { Oil } \\
\text { (gallons) }\end{array}$ & $\begin{array}{r}\text { Electricity } \\
\text { (MWh) }\end{array}$ & $\begin{array}{r}\text { Total } \\
\text { Energy } \\
\text { (millions of Btus) }\end{array}$ \\
\hline FACILITIES & & & & \\
Waste to Energy & 7,600 & 185,728 & 12,056 & 69,450 \\
Material Recovery Facility & 14,100 & & 819 & 4,860 \\
Yard Waste Composting & 4,706 &. & Unknown & 0 \\
White Good Processing & & & & 2,740 \\
LANDFILL & 18,700 & & & 77,740 \\
\hline TOTAL & 45,106 & & & 0 \\
\hline
\end{tabular}

Notes:

a. Diesel fuel consumed at facilities and the landfill is for rolling stock.

b. Energy consumption data at WTE facility was provided by Springfield Resource Recovery, Inc.

c. Energy consumption data at the MRF was provide by Resource Recovery Systems, inc.

c. Energy consumption data at the Bondi's Island Landfill was provided by United Waste Systems, Inc. 
Inc., Resource Recovery Systems, Inc., and United Waste Systems, Inc., ${ }^{\text {ss }}$ respectively. Environmental Maintenance indicated that it used electricity to operate the white goods bailers, but was unable to provide an estimate of the quantity of electricity consumed.

The energy used to operate equipment at the compost site was supplied by the City DPW and is provided in Table 5-3. Both the dump truck and front-end loader are also used for snow removal. For this analysis it is assumed that all of the fuel consumed by the dump truck and front-end loader was for the compost operation. ${ }^{56}$

\subsection{Energy Consumption to Transport Recovered Materials to Remanufacturers}

The majority of the material recovered at the MRF is transported by transfer trailer to the remanufacturers. (Less than 10 percent, i.e., the tin cans, is shipped by rail.) The estimated gallons of diesel fuel used to haul the recovered materials, exclusive of tin cans, by transfer trailer are provided in Table 5-5. These estimates are based on the tonnage and distance travelled information provided in Table 3-3 of Section 3 and an assumed fuel consumption of 0.023 gallons per ton-mile. ${ }^{57}$

Aluminum was hauled the greatest distance, i.e., about 1,300 miles, at an energy consumption rate of about 30 gallons per ton. At the other extreme, mixed glass was hauled only 20 miles, at an average energy consumption rate of 0.5 gallons per ton. Over 75 percent of the material accounted for in Table 5-4 is paper products (i.e., newspaper, corrugated, and other cartons). The paper products were shipped between 75 to 85 miles, at an average energy consumption rate of 1.9 gallons per ton. The weighted average fuel consumed to transport all the recovered materials to the remanufactures is estimated to be 1.8 gallons per ton.

Environmental Maintenance, the contractor that processed and marketed the white goods collected in Springfield in FY 1993, indicated that it transports white goods between "110 miles to 1,200 miles, depending on market conditions. ${ }^{158}$ For this analysis, a distance of 350 miles is assumed. At 0.023 gallons per ton-mile, this results in an energy consumption rate of about 8 gallons of diesel fuel per ton.

The 3,127 tons of compost purchased by Ray Haluch, Inc. was hauled about 20 miles using 20and 45-cubic-yard dump trucks. Using a bulk density of the compost of 1,000 pounds per

ss United Waste Systems purchased Resource Control, Inc., the operator of the landfill during FY 1993.

56 Snow removal occurs infrequently during the winter months; therefore, only a small percentage of the energy consumption is attributable to snow removal. Because no information was available that would allow a reasonable allocation of the energy used for snow removal, no such allocation is made in this report. Thus, the estimated energy consumed for the yard waste composting operation is overestimated.

57 The energy consumed per ton-mile is based upon detailed transfer-trailer fuel consumption data obtained in Palm Beach County, Florida.

58 Letter from Environmental Maintenance to CSI, June 20, 1994. 
Table 5-5: Equivalent Gallons for Transporting Recyclables

\begin{tabular}{lrrrr}
\hline Recyclables & & & Equiv & Equiv. \\
& Tons & Miles & \multicolumn{1}{c}{ Gal. } & Gal/Ton \\
\hline Color Sorted Glass & 5,006 & 70 & 8,060 & 1.6 \\
Mixed Glass & 4,754 & 20 & 2,190 & 0.5 \\
Aluminum & 148 & 1,300 & 4,430 & 29.9 \\
Steel & 33 & 570 & 430 & 13.0 \\
PET Plastic & 72 & 53 & 90 & 1.3 \\
HDPE Plastic & 293 & 55 & 370 & 1.3 \\
Newspaper & 25,396 & 85 & 49,650 & 2.0 \\
Corrugated & 2,636 & 75 & 4,550 & 1.7 \\
Cartons & 84 & 85 & 160 & 1.9 \\
TOTAL & 38,422 & & 69,930 & 1.8 \\
& & & & \\
Paper Only & 28,116 & & 54,360 & 1.9 \\
White Goods & 509 & 350 & 4,100 & 8.1. \\
Compost & 3,127 & 20 & 910 & 0.3 \\
\hline
\end{tabular}

Note: Except for compost, fuel consumption is based on average consumption for transfer trailers of .023 gallons per ton-mile. 
cubic $^{39}$ each truck load was 10 to 23 tons. Assuming that each truck averaged about 5 miles per gallon, 0.18 to 0.40 gallons were consumed for each ton of compost. The mid-point of this range is about 0.3 gallons per ton, which is the value used in Table 5-5.

\subsection{Energy Consumed to Manage Garbage, Bulky Waste, White Goods, Yard. Waste, Office Paper, and Curbside Recyclables}

Table 5-1 showed the equivalent gallons of diesel fuel used to manage a ton of garbage, nonrecyclable bulky waste, yard waste, white goods, office paper, or curbside recyclables. The collection vehicle data in Table 5-1 was taken from Table 5-2.

The facility energy consumption per ton shown in Table 5-1 was calculated from the "Total Energy" data provided in Table 5-4. For example, the total energy use at the WTE facility was 69,450 million Btus. This is approximately equal to 474,400 gallons of diesel fuel (i.e., 69,450 million divided by 146,390 ). In FY 1993, 115,916 tons of garbage were processed at the WTE facility. Thus the number of equivalent gallons per ton is calculated to be 4.1 (i.e., 474,400 divided by 115,916$)$.

The landfill energy consumption is based upon the fraction of the input tonnage that eventually is disposed of at a landfill. In all cases the average energy consumption at the Bondi's Island Landfill is used. For example, 38,376 tons of ash was generated from the 115,916 tons of garbage processed at the WTE facility. Therefore, for each ton of garbage processed at the WTE facility, about 0.33 tons of residue were disposed of at a landfill. For each of the 53,970 tons of waste disposed of at the Bondi's Island Landfill about 0.34 equivalent gallons of diesel fuel were consumed (i.e., 2,740 million Btus divided by 146,390 divided by 53,970). The energy consumed at the landfill for each ton of garbage processed at the WTE facility was about 0.1 equivalent gallons of diesel fuel (i.e., 0.34 times 0.33 ). Similarly, for each ton of white goods collected and processed about 0.15 tons of residue required landfilling. Thus, about 0.05 equivalent gallons of diesel fuel were consumed at a landfill for each ton of white goods collected and processed (i.e., 0.34 time 0.15).

The energy consumed to haul recovered materials to market shown in Table 5-1 was obtained from Table 5-5.

\subsection{Energy Production at the WTE Facility}

In FY 1993 the WTE facility sold $41,687,910 \mathrm{kWh}$ of electricity and $11,069,000$ pounds of steam at $460 \mathrm{psig}, 450-500^{\circ} \mathrm{F}^{60}$ Assuming a 10,000-Btu-per-kWh heat rate for electric power plants, an estimated 24.6 equivalent gallons of diesel fuel per ton of MSW processed were conserved from the sale of electricity from the WTE facility (i.e., $41,687,910 \mathrm{kWh}$ multiplied by 10,000

${ }^{59}$ Lund, Herbert F., editor, "The McGraw-Hill Recycling handbook," McGraw-Hill, Inc., 1993, p. 16.3.

${ }^{60}$ In total, Springfield Resource Recovery sold $65,879,000$ pounds of steam for use at the wastewater treatment plant. An additional $54,810,000$ pounds of steam were generated by an oil-fired package boiler located at the WTE facility. Neither the oil consumed nor the steam generated by the package boiler is included in this analysis. 
Btu/kWh divided by $146,390 \mathrm{Btu} /$ gallon divided by 115,916 tons). Assuming a boiler efficiency of 85 percent, another 0.9 equivalent gallons of diesel fuel per ton of MSW processed were conserved from the sale of steam from the WTE facility. In total, each ton of MSW processed at the WTE facility conserved about 25.5 equivalent gallons of diesel fuel. 


\section{Environmental and Safety Regulations and Permit Requirements}

The costs of compliance with the environmental and safety regulations and their related permit requirements discussed in this section are reflected in the costs and energy consumption levels reported in this case study.

\subsection{Overview of Federal Environmental Legislation and Regulations}

The potential environmental impacts of solid waste management facilities have led to the development of an extensive network of federal and state regulations. Embodied in many federal environmental laws is an implicit federal-state partnership whereby the federal government sets the agenda and standards for pollution abatement while the states carry out the day-to-day activities of implementation and enforcement.

The Clean Air Act, most recently amended in 1990, established programs for protecting public health and the environment from exposure to toxic air pollutants. ${ }^{61}$ The Clean Water Act, most recently amended in 1987, is the principal federal law protecting the nation's waterways from pollution. ${ }^{62}$ The Safe Drinking Water Act, most recently amended in 1988, established programs for protecting public drinking water systems from harmful contaminants. ${ }^{63}$ The Solid Waste Disposal Act and Resource Conservation and Recovery Act (RCRA) of 1976, most recently amended in 1992 and currently undergoing Congressional review for reauthorization, is the main piece of federal legislation addressing landfill disposal regulation. ${ }^{64}$ A brief summary of these four federal Acts as they apply to solid waste management facilities is given below.

In February 1991, the U.S. Environmental Protection Agency (EPA) issued final rules for municipal waste combustors in response to the Clean Air Act. These rules, commonly referred to as the New Source Performance Standards (NSPS), apply to municipal waste combustors with capacities of 250 tons per day or greater, and whose construction, reconstruction, or modification commenced after December 20, 1989. ${ }^{65}$ The NSPS establish maximum emission levels for new or extensively modified major stationary sources. These emission levels were determined by "best adequately demonstrated" continuous control technology analysis and are presented in Table 6$1 .^{66}$ In addition to the NSPS, the EPA also proposed emissions limitations for existing (i.e., constructed, reconstructed, or modified prior to December 20,1989) municipal waste combustors.

61 The Clean Air Act and Major Amendments are codified as 42 U.S.C. 7401-7671, 1990.

62 The Clean Water Act and Major Amendments are codified as 33 U.S.C. 1251-1387, 1987.

63 The Safe Drinking Water Act and Amendments are codified as 42 U.S.C. 300f-300j-11, 1988.

64 The Solid Waste Disposal/Resource Conservation and Recovery Act and Major Amendments are codified as 42 U.S.C. 6901-6991k, 1992.

65 Federal Register, "Standards of Performance for New Stationary Sources: Municipal Waste Combustors," Vol. 56, No. 28, pages 5488-5527, 1991.

66 Congressional Research Service, "Summary of Environmental Laws Administered by the Environmental Protection Agency," The Library of Congress, January 1993. 
Table 6-1: New Source Performance Standards

\begin{tabular}{|c|c|c|c|c|}
\hline Pollutant & Emission Limit & Technology Basis ${ }^{d}$ & Monitoring & \\
\hline Dioxins and Furans & $30 \mathrm{ng} / \mathrm{dscm}$ & GCP, SD/FF & & Annual Stack Test ${ }^{2}$ \\
\hline Particulate Matter & $34 \mathrm{mg} / \mathrm{dscm}$ & FF &.. & Annual Stack Test ${ }^{2}$ \\
\hline Opacity & $10 \%$ & $\mathrm{FF}$ & & CEMS, 6-min. avg. \\
\hline Sulfur Dioxide & $30 \mathrm{ppm}$ or $80 \%$ reduction & $\mathrm{SD} / \mathrm{FF}$ & & CEMS, 24-hr. avg. \\
\hline Hydrogen Chloride & $25 \mathrm{ppm}$ or $95 \%$ reduction & $\mathrm{SD} / \mathrm{FF}$ & & Annual Stack Test ${ }^{2}$ \\
\hline Nitrogen Oxides & $180 \mathrm{ppmv}^{\mathrm{c}}$ & SNCR & & CEMS, 24-hr. avg. \\
\hline Carbon Monoxide: & . & & & \\
\hline $\begin{array}{l}\text { Modular } \\
\text { Massburn } \\
\text { Massburn/Rotary } \\
\text { Fluidized Bed } \\
\text { RDF/Full-Dedicated } \\
\text { RDF/Co-Fired }\end{array}$ & $\begin{array}{l}50 \mathrm{ppmv} \\
100 \mathrm{ppmv} \\
100 \mathrm{ppmv} \\
100 \mathrm{ppmv} \\
150 \mathrm{ppmv} \\
150 \mathrm{ppmv}\end{array}$ & $\begin{array}{l}\text { GCP } \\
\text { GCP } \\
\text { GCP } \\
\text { GCP } \\
\text { GCP } \\
\text { GCP }\end{array}$ & & $\begin{array}{l}\text { CEMS, 4-hr. avg. } \\
\text { CEMS, 4-hrs. avg. } \\
\text { CEMS, 24-hr. avg. } \\
\text { CEMS, 4-hr. avg. } \\
\text { CEMS, 24-hr. avg. } \\
\text { CEMS, 4-hr. avg. }\end{array}$ \\
\hline
\end{tabular}

Source: $\quad$ Federal Register, "Standards of Performance for New Stationary Sources: Municipal Waste Combustors," Vol. 56, No. 28, 1991.

$1 \quad$ All emission limits are dry basis corrected to $7 \% \mathrm{O}_{2}$.

2 In the case of small plants (less than 250 TPD), if compliance is demonstrated for two consecutive years, the facility need only conduct testing every third year. If a non-compliant result occurs, another two years of consecutive testing must be done before the facility can switch back to the three-year cycle.

3 The $\mathrm{NO}_{\mathrm{x}}$ standard applies to large plants only; small plants are exempt.

4. Good Combustion Practice (GCP); Spray Dryer (SD); Fabric Filter (FF); Selective Non-Catalytic Converter (SNCR). 
The owner/operator of a proposed municipal waste combustor must apply for a Prevention of Significant Deterioration (PSD) permit and conduct a Best Available Control Technology (BACT) analysis to determine the applicable level of emissions control. BACT analysis evaluates the energy, environmental; and economic impacts of various alternative control technologies. The PSD permit requirements reflect the principle which holds that areas where the air quality is better than required by the national ambient air quality standards (NAAQS) established for six criteria pollutants (ozone, sulfur, dioxide, $\mathrm{NO}_{x}$, carbon monoxide, lead, and particulates) should be protected from significant new air pollution, even if the NAAQS would not be violated by a proposed new source. Areas not meeting NAAQS are called nonattainment areas and are subject to more stringent control requirements determined by "reasonable available control technology" (RACT).

Emissions from municipal waste combustors, in addition to meeting allowable limits, must also be monitored by the facility owner/operator. Monitoring requirements for existing facilities include continuous emissions monitoring for carbon monoxide and sulfur dioxide. Annual stack testing must be conducted for particulate matter, dioxin/furans, hydrogen chloride, and opacity.

The 1991 EPA regulations also required that chief facility operators and shift supervisors be certified in accordance with operating standards established by the American Society of Mechanical Engineers (ASME). While the states must develop certification programs with standards meeting those of ASME, no formal training requirement is included in the regulations.

Pursuant to the Clean Water Act, a solid waste management facility cannot cause a discharge of pollutants that is in violation of the requirements of the National Pollutant Discharge Elimination System (NPDES) into United States waters. The states are responsible for establishing water quality standards and are authorized to issue discharge permits. The NPDES permit requires the source to attain technology-based effluent limits, "best practicable control technology" (BPT), and "best available technology" (BAT). The initial BPT limitations focus on regulating discharges of conventional pollutants such as bacteria and oxygen-consuming materials. The BAT limitations emphasize controlling toxic pollutants such as heavy metals, pesticides, and other organic chemicals. Table $6-2$ provides a listing of the pollutants regulated under the NPDES.

A separate permit is required to dispose of dredge or fill material into the waters, including wetlands. The U.S. Army Corps of Engineers administers this permit program. Other regulations promulgated under the Clean Water Act include guidelines for using and disposing of sewage sludge.

Pursuant to the Safe Drinking Water Act, a facility or practice cannot contaminate an underground drinking water source beyond the solid waste management facility boundary or beyond an alternate boundary. Table $6-3$ provides the maximum contaminant levels as promulgated under this Act. The primary enforcement responsibility lies with the states, provided they adopt regulations as stringent as the federal requirements, develop adequate procedures for enforcement, maintain records, and create plans providing emergency water supplies.

Pursuant to RCRA, criteria were established to determine which solid waste disposal facilities and 
Table 6-2: Pollutants Regulated by the NYDES Permit Program

\begin{tabular}{|c|c|}
\hline $\begin{array}{l}\text { Oxygen Demand: } \\
\text { Biochemical Oxygen Demand } \\
\text { Chemical Oxygen Demand } \\
\text { Total Oxygen Demands } \\
\text { Total Organic Carbon } \\
\text { Other }\end{array}$ & $\begin{array}{l}\text { Metals: } \\
\text { Aluminum } \\
\text { Cobalt } \\
\text { Iron } \\
\text { Vanadium }\end{array}$ \\
\hline $\begin{array}{l}\text { Solids: } \\
\text { Total Suspended Solids (Residues) } \\
\text { Total Dissolved Solids (Residues) } \\
\text { Other }\end{array}$ & $\begin{array}{l}\text { Metals (All Forms) } \\
\text { Other metals not specifically } \\
\text { listed under Group } 1\end{array}$ \\
\hline $\begin{array}{l}\text { Nutrients: } \\
\text { Inorganic Phosphorus Compounds } \\
\text { Inorganic Nitrogen Compounds } \\
\text { Other }\end{array}$ & $\begin{array}{l}\text { Inorganic } \\
\text { Cyanide } \\
\text { Total Residual Chlorine }\end{array}$ \\
\hline $\begin{array}{l}\text { Detergents and Oils: } \\
\text { MBAS } \\
\text { NTA } \\
\text { Oil and Grease } \\
\text { Other Detergents or Algicides }\end{array}$ & $\begin{array}{l}\text { Minerals: } \\
\text { Calcium } \\
\text { Chloride } \\
\text { Fluoride } \\
\text { Magnesium } \\
\text { Sodium } \\
\text { Potassium } \\
\text { Sulfur } \\
\text { Sulfate } \\
\text { Total Alkalinity } \\
\text { Total Hardness } \\
\text { Other Minerals }\end{array}$ \\
\hline
\end{tabular}

Source: 40 CFR, EPA, Part 123-"Appendix A - Criteria for Reporting in the NPDES Programs." 
Table 6-3: Maximum Contaminant Levels Promulgated Under the Safe Drinking Water Act

\begin{tabular}{ll}
\hline Chemical & MCL (mg/l) \\
\hline Arsenic & 0.05 \\
Barium & 1.0 \\
Benzene & 0.005 \\
Cadmium & 0.01 \\
Carbon Tetrachloride & 0.005 \\
Chromium (Hexavalent) & 0.05 \\
2,4-Dichlorophenoxy Acetic Acid & 0.1 \\
1,4-Dichlorobenzene & 0.075 \\
l,2-Dichloroethabe & 0.005 \\
1,1-Cichloroethylene & 0.007 \\
Endrin & 0.0002 \\
Fluoride & 4.0 \\
Lindane & 0.004 \\
Lead & 0.05 \\
Mercury & 0.002 \\
Methoxyclor & 0.1 \\
Nitrate & 10.0 \\
Selenium & 0.01 \\
Silver & 0.05 \\
Toxaphene & 0.005 \\
1,1,1-Trichloroethane & 0.2 \\
Trichloroethylene & 0.005 \\
2,4,5-Trichlorophenoxy Acetic Acid & 0.01 \\
Vinyl Chloride & 0.002 \\
&
\end{tabular}

Source: 40 CFR, EPA, Part 257 - "Criteria for Classification of Solid Waste Disposal Facilities and Practices." 
practices pose a reasonable probability of adverse effects on public health or the environment. ${ }^{67}$ The objective of these criteria is to mitigate adverse effects through the protection of floodplains, endangered species, surface water, and groundwater.

Subtitle D of RCRA primarily addresses non-hazardous waste, whereas Subtitle C of RCRA addresses hazardous waste disposal. In October 1991, the EPA promulgated revised Subtitle D regulations applicable to municipal solid waste landfills, with an effective date of October 1993. In general, the new regulations require liners, leachate collection, groundwater monitoring, and corrective action at municipal landfills. ${ }^{68}$

The management of ash from municipal waste combustors is also governed by regulations established pursuant to RCRA. Much controversy surrounds the toxicity of incinerator ash and whether it should be classified as a hazardous waste under Subtitle C of RCRA, as a nonhazardous waste under Subtitle D of RCRA, or as a special waste. In 1991, the EPA began requiring the use of the Toxic Characteristic Leaching Procedure (TCLP) to determine the toxicity of ash. During FY 1993, municipal waste combustor ash was regulated under Subtitle D as a "special waste" that requires special handling regardless of the TCLP results concerning toxicity. In the absence of sufficient federal guidance on municipal waste combustor ash disposal, some states took the lead in developing requirements and rules. ${ }^{69}$

Other federal regulatory agencies with permitting oversight of solid waste management facilities include: the Federal Aviation Administration (FAA), which reviews processing plants that require tall emission stacks, and the Federal Energy Regulatory Commission (FERC), which reviews processing plants that generate electric power.

\subsection{Overview of State and Local Environmental Regulations}

At a minimum, state regulators are required to adopt and enforce the federal requirements, but they may choose to impose more stringent or more extensive requirements. A brief summary of the Commonwealth of Massachusetts' regulations for solid waste management activities follows. Specific requirements for the facilities constituting components of the Springfield IMSWM System

\footnotetext{
67 40 CFR, EPA, Part 257--"Criteria For Classification of Solid Waste Disposal Facilities and Practices."

${ }^{68}$ On October 1, 1993, the Federal criteria for MSW landfills under subtitle D of RCRA were amended to extend the date of compliance for small landfills to April 9, 1994, and by delaying the effective date of subpart G, Financial Assurance, to April 9, 1995, for all MSW landfills. In addition, the MSW landfill criteria were amended by removing the exemption from the groundwater monitoring requirements and by delaying the date for compliance with all requirements of the MSW landfill criteria for two years for owners and operators of MSW landfill units in arid and remote areas that meet the qualifications of the small landfill exception in the MSW landfill criteria. (Federal Register, "Solid Waste Disposal Facility Criteria; Delay of Compliance and Effective Dates," Vol. 58, No. 189, pages 51536-51548, 1993.)

69 On May 2, 1994, the U.S. Supreme Court ruled that ash from municipal waste combustors is not exempt from the Subtitle C requirements of RCRA as is MSW. Under RCRA, regular testing of ash, principally for toxic metals, lead, and cadmium, will be required. Ash deemed to be hazardous must be disposed of in licensed hazardous waste disposal facilities that protect groundwater.
} 
are then discussed.

In 1987, the Commonwealth enacted the Solid Waste Act, whose public purpose is to "eliminate, mitigate, and prevent nuisances and adverse public health effects associated with the collection, processing and disposal of solid waste. ${ }^{170}$ The Massachusetts Department of Environmental Protection (DEP) is responsible for the execution and enforcement of the provisions of this Act. Solid waste management facilities and practices in Massachusetts are regulated pursuant to the Code of Massachusetts Regulations, Title 310-Department of Environmental Protection, Chapter 19 (310 CMR 19). The regulations were developed "to protect public health, safety and the environment by comprehensively regulating the storage, transfer, processing, treatment, disposal, use and reuse of solid waste. Protection of public health, safety and the environment is primarily the prevention of pollution from the site, but also encompasses the operation of the facility within an integrated solid waste management system which maximizes material reuse and the conservation of energy."11

These regulations are divided into three parts: Part I regulations establish general requirements, procedures, and permits; Part II regulations establish landfill design and operational standards; and Part III regulations establish transfer station design and operational standards. The regulations also require MSW landfills and waste-to-energy facility owners/operators to provide for recycling or composting of a minimum of 25 percent by weight of the average yearly amount of MSW the facility is approved to accept. The 25-percent recycling or composting requirement may be met by any combination of the following activities:

- recycling or composting at the facility;

- recycling or composting at a recycling or composting facility located at a different site;

- demonstration that the recyclable or compostible materials are being diverted by a generator or intermediate handler and are being recycled or composted prior to the waste being delivered to the facility; or

- provision of the opportunity to recycle or compost.

Specific restrictions on the disposal of certain components of the solid waste stream, such as lead batteries, tires, yard waste, et. al., are listed in Table 6-4. MSW landfills or waste-to-energy facilities cannot accept the restricted material except to handle, recycle, or compost the material in accordance with 310 CMR 19.

The City of Springfield regulates solid waste practices pursuant to Title 7, Chapter 7,16, Solid Waste, Litter and Weeds of the City Ordinances (1986) and subsequent amendments. In 1986,

\footnotetext{
70 Massachusetts General Laws, Chapter 21H-Solid Waste Facilities; 1987, most recently amended 1992.

71310 CMR 19, DEP-Solid Waste Management; adopted 1990; most recently amended 1992. For purposes of this case study, 1992 regulations are cited unless otherwise noted.
} 
Table 6-4: Implementation Schedule For Waste Disposal Bans

\begin{tabular}{lll}
\hline Restricted Material & $\begin{array}{l}\text { Effective Date of } \\
\text { Restriction }\end{array}$ & Restriction on Disposal \\
\hline $\begin{array}{l}\text { Lead Batteries } \\
\text { Leaves }\end{array}$ & $12 / 31 / 90$ & Ban on disposal or incineration \\
Tires & $12 / 31 / 91$ & $\begin{array}{l}\text { Ban on disposal or incineration } \\
\text { Ban on disposal of whole tires only at } \\
\text { landfills. Tires must be shredded prior } \\
\text { to disposal in landfills. }\end{array}$ \\
White Goods & $12 / 31 / 91$ & Ban on disposal or incineration \\
Other Yard Waste & $12 / 31 / 91$ & Ban on disposal or incineration \\
Post-Consumer Recyclables & $12 / 31 / 92$ & Ban on disposal or incineration \\
Aluminum Containers & $12 / 31 / 92$ & Ban on disposal or incineration \\
Metal or Glass Containers & $12 / 31 / 92$ & Ban on disposal or incineration \\
Single Polymer Plastics & $12 / 31 / 94$ & Ban on disposal or incineration \\
Recyclable Paper & $12 / 31 / 94$ &
\end{tabular}

Source: 310 CMR 19.07 - Waste Control, DEP-Solid Waste Management. . 
through an amendment ${ }^{72}$ to this Chapter, the City established a mandatory curbside recycling program to take effect upon the commencement of the commercial operation of the MRF (January 1990). The program mandates separation of aluminum, glass, ferrous metal cans, newspaper, and corrugated paper from MSW into recycling receptacles provided to each household. A fine not to exceed $\$ 50$ can be assessed to any violators of this Chapter.

In 1988, through an amendment ${ }^{73}$ to Chapter 7.16 , the City established a program for the mandatory separation of certain compostible leaf and yard waste material from garbage and the collection of these compostible leaf and yard waste materials at the curbside. During the leaf and yard waste collection season, the leaf and yard waste must be placed in paper leaf bags or barrels at the curbside. Any violators can be assessed a fine not to exceed $\$ 50$.

In 1992, Chapter 7.17 Bulk and Waste Handling Services ${ }^{74}$ was added to the City Ordinances. These regulations require the licensing of bulk and waste haulers who engage in collecting, removing, hauling, or transporting any garbage, refuse, rubbish, hazardous waste or other waste in the City. Licensing criteria include: automobile insurance policy; $\$ 2,000$ bond, as surety for the observance of the provisions of the ordinances including disposal at approved sites; and recordkeeping of all receipts from approved disposal sites for a period of six years. Any person operating as a hauler without a license can be fined not more than $\$ 300$ for each day in violation of this chapter.

\subsubsection{Permit Requirements for Each IMSWM System Facility}

This section summarizes the permit conditions for each of the facilities included in the City's IMSWM System. The DEP requirements for new and existing solid waste management facilities $^{75}$ are: (a) a valid site assignment ${ }^{76}$; (b) a solid waste management facility permit; (c) authorization to construct the facility; and (d) authorization to operate the facility.

\subsubsection{Waste-to-Energy Facility}

In 1983, the Agawam Board of Health issued the Site Assignment for the WTE facility. The Massachusetts Environmental Policy Act (MEPA) approval by the Secretary of Environmental Affairs was issued on December 28, 1984. The DEP issued the PSD permit and Permit to Construct and Operate on December 27, 1985. On June 27, 1986, the DEP reissued the PSD permit to the new facility owner, Fluor Resource Recovery. The WTE facility is currently operated by Springfield Resource Recovery, Inc. (SRR), a subsidiary of Fluor. The PSD permit

12 Ordinances of the City of Springfield, Title 7, Chapter 7.16.040 Mandatory Recycling, June 16, 1986.

${ }^{73}$ Ordinances of the City of Springfield, Title 7, Chapter 7.16.041 Mandatory Leaf and Yard Waste Composting, October 3, 1988.

74 Ordinances of the City of Springfield, Title 7, Chapter 7.17 Bulk and Waste Hauling Services, August 18, 1992.

75310 CMR 19, DEP-Solid Waste Management.

76310 CMR 16.00, DEP-Site Assignment Regulations for Solid Waste Facilities. 
allows for the operation of three furnaces, each rated at a 120-TPD MSW throughput capacity, with a combined maximum annual throughput capacity of 131,400 TPY. Fluor Resource Recovery applied for a modification to the PSD permit and DEP authorization to operate. On June 17, 1993, the DEP approved an increase of the daily facility MSW throughput capacity from 360 TPD to 408 TPD, with no increase in the annual maximum MSW throughput capacity. The change in allowable daily throughput capacity did not require additional emissions control or change in permitted emissions rates for any pollutants except $\mathrm{NO}_{\mathrm{x}}$ and lead. Permit conditions of the PSD permit are outlined on Table 6-5, Emission Limits.

The WTE facility is permitted to discharge wastewater into the Regional Wastewater Treatment Facility in accordance with the City's Sewer Use Ordinance ${ }^{77}$ and the allowable discharge limitations listed on Table 6-6.

Table 6-7 summarizes the permitting activities for the WTE facility from November 30, 1983, through June 17, 1993.

The WTE facility was in compliance with all DEP permit requirements during FY 1993.

\subsubsection{Materials Recovery Facility}

In accordance with the Site Assignment Regulations ${ }^{78}$, the DEP determined that a site assignment was not necessary-for the MRF, which handles only pre-sorted recyclable materials. Consistent

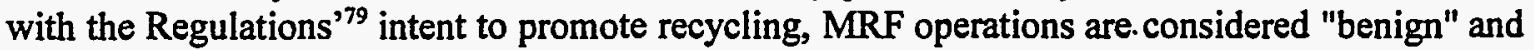
therefore are not subject to the myriad of regulations applicable to other solid waste management facilities, such as MSW landfills and waste-to-energy facilities. ${ }^{80}$

\subsubsection{Yard Waste Composting}

Yard waste composting facilities are conditionally exempt from Site Assignment Regulations. ${ }^{81}$ The City's yard waste composting operation is registered with the DEP.

\subsubsection{Bondi's Island Landfill}

Permitting activities for the Bondi's Island MSW landfill began in 1966, when the West Springfield section received its site assignment. The Agawam Board of Health issued the site assignment for the Agawam section of the landfill on August 19, 1968. Massachusetts

77 Ordinances of the City of Springfield, Title 11, Chapter 11.08 Sewer Use Ordinance.

38310 CMR 16, DEP, Site Assignment Regulations for Solid Waste Facilities, Section 16.05(4), adopted 1988, most recently 1990.

79310 CMR 19, DEP, Solid Waste Management.

80 Mark Sliewitz, DEP, telephone conversation of March 9, 1994.

81310 CMR 16, DER, Site Assignment Regulations for Solid Waste Facilities, Section 16.05(3); Adopted 1988; 1990. 
Table 6-5: Emissions Limits - Springfield RRF

\begin{tabular}{lll}
\hline Pollutant & PSD Limits & Amendment $^{\mathbf{b}}$ \\
\hline Nitrogen Oxides $\left(\mathrm{NO}_{x}\right)$ & $0.33 \mathrm{lbs} / \mathrm{MMBtu}$ & $0.242 \mathrm{lbs} / \mathrm{MMBtu}$ \\
Sulfur Dioxide $\left(\mathrm{SO}_{2}\right)$ & $0.13 \mathrm{lbs} / \mathrm{MMBtu}$ & \\
Particulates (TSP) & $0.03 \mathrm{~g} /$ dscf_corrected to $12 \%$ & \\
& $\mathrm{CO}_{2}$ & \\
Lead & $4.80 \times 10^{-3} \mathrm{lbs} / \mathrm{MMBtu}$ & $1.0 \times 10^{-3} \mathrm{lbs} / \mathrm{MMBtu}$ \\
Beryllium & $1.2 \times 10^{-6} \mathrm{lbs} / \mathrm{MMBtu}$ & \\
Mercury & $2.6 \times 10^{-4} \mathrm{lbs} / \mathrm{MMBtu}$ & \\
Opacity & $\geq 20 \%$ & \\
\hline
\end{tabular}

PSD \#PV-85-IN-006, 6/27/86.

Burn Rate Increase Amendment, 6/17/93.

Table 6-6: Wastewater Discharge Limitations - Springfield RRF

\begin{tabular}{lc}
\hline Pollutant & Units (mg/l) \\
\hline Total Chromium & 0.133 \\
Total Zinc & 0.667 \\
Total Iron & 35.0 \\
Total Manganese & 1.0 \\
Total Sulfide & 24.0 \\
Priority Pollutants & No Detectable \\
& Amounts \\
\hline
\end{tabular}




\section{Table 6-7: Permitting Activity - Springfield RRF}

\begin{tabular}{lll}
\hline Permit/Approval Date & Review Agency & Description of Permit/Approval \\
\hline $11 / 30 / 83$ & Agawam Board of Health & Site Assignment \\
$12 / 28 / 84$ & Secretary of Environmental Affairs & Certification of the Final EIR \\
$12 / 27 / 85$ & DEP & PSD \\
$12 / 27 / 85$ & DEP & Permit to Construct \\
$6 / 27 / 86$ & DEP & Land Use \\
$6 / 27 / 86$ & DEP & PSD - Reissued \\
$5 / 4 / 88$ & DEP & CEM Approval \\
$9 / 23 / 88$ & DEP & Amended APC Equipment Approval \\
$10 / 3 / 88$ & DEP & Emission Compliance Test Protocol Approval \\
$4 / 28 / 89$ & DEP & Deflow Prevention Device Approval \\
$6 / 27 / 91-11 / 27 / 92$ & DEP & Permit to Operate (ATO) \\
$12 / 2 / 92$ & DEP & Permit for the Burning of Tires \\
$11 / 4 / 91$ & DEP (Air Quality) & Consent Order - Miscellaneous Issues \\
$2 / 8 / 91$ & DEP & Consent Order - Hg Emissions \\
$5 / 28 / 93$ & DPW & Wastewater Discharge Permit \\
$6 / 17 / 93$ & DEP & Conditional Approval of Burn Rate Increase (PSD \\
& & Modification) \\
\hline
\end{tabular}


Springfield applied for an existing facility permit pursuant to 310 CMR 19.030 .

In accordance with DEP regulations ${ }^{82}$, the Bondi's Island Landfill incorporates a double liner "system comprised of a primary 60-mil high density polyethylene (HDPE) liner installed over a. . 2- to 4-foot thick, low permeability $\left[10^{-7}\right]$, clay secondary liner. A one-foot sand blanket serves as protection and facilitates leachate drainage. An extensive leachate collection system conveys leachate to an aerated, flow-through pretreatment facility to the wastewater treatment plant. The collection system was designed also to collect and pretreat contaminated groundwater generated from existing unlined sections of the landfill.

All material delivered to the landfill is covered with six inches of soil daily, in accordance with DEP regulations ${ }^{83}$. A 14-working-day stockpile of daily cover is available on- site at all times. Immediate cover is also applied as required.

Environmental monitoring requirements include: surface and groundwater; secondary leachate collection; leachate monitoring; and gas monitoring. Monitoring of surface and groundwater is performed semi-annually for the indicator parameters shown in Table 6-3. Landfill gas samples are analyzed quarterly for volumes and concentrations of explosive gases.

In July 1989, the City, SRRI, and DEP entered into a compliance order for additional dewatering of ash residue entering the landfill from the WTE facility. An ash building was constructed in 1992 to accomplish this function and to satisfy the order. During FY 1993, the Bondi's Island Landfill operated in compliance with all other permit conditions.

\subsection{Overview of Occupational Health and Safety Regulations}

\subsubsection{Federal Regulations}

The Occupational Safety and Health Act of $1970^{84}$ imposes two basic duties on private employers. State and local governments in their roles as employers are not required to comply with these duties, which are:

(1) To comply with occupational safety and health standards developed by the Occupational Safety and Health Administration (OSHA) pursuant to the Occupational Safety and Health Act; and

(2) To comply with the General Duty Clause, Section $5(a)(1)$, which requires that employers protect their employees from recognized hazards not regulated by an OSHA standard.

32310 CMR 19, DEP, Solid Waste Management.

83310 CMR 19, DEP, Solid Waste Management.

84 Occupational Safety and Health Act of 1970, 5 USC 5108, 1970, most recently amended October 1992. 
Pursuant to the Occupational Safety and Health Act, OSHA, created within the Department of Labor is responsible for promulgating legally enforceable standards. These OSHA standards require conditions, or the adoption or use of one or more practices, means, methods, or processes, reasonably necessary and appropriate to protect workers on the job. These standards include the General Industry Standards, 29 CFR Part 1910, which apply to all workplaces unless more specific OSHA standards apply. The General Industry Standards are applicable to solid waste processing facilities and are listed in Table 6-8.

Periodic inspections, either routine or in response to complaints, are conducted by OSHA to ensure that specific applicable standards are being met and that the workplace is generally free from recognized hazards likely to cause serious injury or death. When OSHA compliance officers discover areas of non-compliance resulting in hazards, employers may be issued citations, and penalties and abatement periods may be proposed.

\subsubsection{State and Local Safety Requirements}

OSHA provisions, as previously mentioned, do not apply to state and local governments in their role as employers. The Act does provide that any state desiring to gain OSHA approval for its private sector occupational safety and health program must provide a program that covers its state and local government workers and that is at least as effective as its program for private employees. State plans may also cover only public sector employees. The Commonwealth of Massachusetts does not have an OSHA-approved state plan.

As previously discussed, all private employers are required to comply with the General Industry Standards developed by OSHA. Thus, the privately owned and operated IMSWM System facilities must comply with OSHA standards. 
Table 6-8: OSHA Standards and Rules

\begin{tabular}{lc}
\hline OSHA STandards and Rules & Requirement \\
\hline Cadmium Standard . & 29 CFR 1910.1027 \\
Chemical Safety and Handling & 29 CFR 1910.120 \\
Confined Space & 29 CFR 1910.146 \\
CPR/First Aid & 29 CFR 1910.151 \\
Crane Operation & 29 CFR 1910.179 \\
Electrical Policy & 29 CFR 1910.300 \\
Emergency Response Drill & 29 CFR 1910.157 \\
Eye Protection & 29 CFR 1910.133 \\
Fire Extinguishers and 1.5" Hose & 29 CFR 1910.157(g) \\
Flammable Materials & 29 CFR 1910.120h (1\&2) \\
Hazard Communication & 29 CFR 1910.120h (1\&2) \\
HazMat Emergency Response Team & 29 CFR 1910.1201(2)i \\
Lead Standard & 29 CFR 1910.1025 \\
Lock Out/Tag Out & 29 CFR 1910.147 \\
Machine Operating and Guarding & 29 CFR 1910.212 \\
Noise (Hearing Protection) & 29 CFR 1910.95(k) \\
Powered Industrial Truck & 29 CFR 1910.178(1) \\
Respirator Training & 29 CFR 1910.134(b)(3) \\
Nuclear & 10 CFR Part 31 \& 32 \\
Scaffolding & 29 CFR 1926.451 \\
\hline & \\
\hline &
\end{tabular}

$\cdot \quad$ Source: $\quad 29$ CFR, OSHA, Part 1901--"Occupational Safety and Health Standards." 



\section{References}

\subsection{General}

City of Springfield, "Mandatory Yard and Leaf Waste Composting," An Ordinance Amending Title 7, Chapter 7.16 of the Revised Ordinances of the City of Springfield, 1986, as Amended, October 7, 1988.

City of Springfield, "Mandatory Recycling," An Ordinance Amending the Revised Ordinances of the City of Springfield, Chapter 9, Section 4, Subsection 7.16.040, June 19, 1886.

City of Springfield, "Case Study in Integrated Solid Waste Management," Paper presented at the tenth annual meeting of the New England Resource Recovery Conference and Exposition, Springfield, MA, June 5, 1991.

City of Springfield, "May 1993 Household Hazardous Waste Collection Preliminary Report," undated.

City of Springfield, "1992 Yard Waste Processing Equipment Grant Application to the Commonwealth of Massachusetts," February 11, 1992.

City of Springfield, "Leaf and Yard Waste Composting Registration Form," Commonwealth of Massachusetts, Department of Environmental Protection, Division of Solid Waste Management, February 11, 1992.

CSI, "MSW Management Assessment Model," Collection Submodel, 1994.

DPW, "Solid Waste Management Plan," March 1994.

DPW, "Springfield Yard Waste Composting Project Summary," undated.

Letter from Michael Pattavina, Project Director, Springfield DPW. to the Editor of the Union News, May 17, 1993. concerning the HHW collection day held on May 1, 1993.

The Green Paint Company, "Paint Collection Tally," May 1, 1993.

Telephone conversation with Mr. William Connors, Clean Harbor of Natick, Inc., May 25, 1994.

Project Management Associates, Inc., "Review of Alternative Disposal Options - City of - Springfield, Massachusetts, November, 1993.

\subsection{Environmetnal Laws and Regulations}

Code of Massachusetts Regulations (CMR), Title 310-Department of Environmental Protection, Chapter 16-Site Assignment Regulations for Solid Waste Facility; Adopted September 1988; May 1990.

CMR, Title 310-DEP, Chapter 19-Solid Waste Management; Adopted July 1990; Amended October 1990; July 1992. 
Massachusetts General Laws (MGL), Chapter 16-Department of Public Works, Solid Waste Disposal; Enacted 1969; most recent amendment 1990.

MGL, Chapter 111-Public Health, Enacted 1955; most recent amendment 1992.

MGL, Chapter 21H-DEP, Solid Waste Facilities, Enacted 1987; most recent amendment 1992.

DEP, A Citizen's Guide to Site Assignment Regulations for Solid Waste Management Facilities, 310 CMR 16.00, October 1988.

SEA Consultants, Inc., "City of Springfield, Existing Facility Permit Application, Bondi Island Landfill," July 1992.

City of Springfield, Ordinances-Title 7, Chapter 7.16 Solid Waste, Litter, and Weeds, 1986.

City of Springfield, Ordinances-Title 7, Chapter 7.16.040 Mandatory Recycling, June 19, 1986.

City of Springfield, Ordinances-Title 7, Chapter 7.16.041 Mandatory Leaf and Yard Waste Composting, June 14, 1988.

City of Springfield, Ordinances-Title 7, Chapter 7.17 Bulk and Waste Hauling Services, August 18, 1992. 


\section{Appendix A - Glossary of Terms}

ALLOCATED COST (\$/year):

AVERAGE COST (\$/ton):

AVERAGE PROGRAM INCREMENTAL COST (SAVINGS) (\$/ton):

BULKY WASTE:

COMMERCIAL MSW:

GARBAGE:

HAZARDOUS WASTE:
That portion of the Total Cost that is expended or apportioned to a specific activity such as the management of garbage, trash, recyclables, yard waste, or household hazardous waste.

Total or Allocated Cost divided by the tons of MSW, garbage, trash, recyclables, or yard waste, as appropriate.

The Program Incremental Cost divided by the number of tons of materials diverted from the landfill by the program.

Oversized items, including white goods and furniture, that have been separated from the MSW stream for separate collection.

Municipal solid waste that is generated by sources other than households, including businesses (e.g., offices, restaurants, retail stores, and industry); institutions (e.g., schools and government establishments); and public areas (e.g., train stations, airports, and litter from roadside).

Garbage is all MSW exclusive of sourceseparated trash, recyclables, yard waste, household hazardous waste, and bulky waste.

Waste which because of its quantity, concentration, or physical, chemical, or infectious characteristics, may pose a substantial present or potential hazard to human health or the environment when improperly treated, stored, transported, disposed of, or otherwise managed and is defined as such in accordance with federal and State laws. Does not include Household Hazardous Waste. 
HOUSEHOLD HAZARDOUS WASTES (HHW):

INTEGRATED SOLID WASTE MANAGEMENT:

MANAGED MSW:

MARGINAL COST (SAVINGS) (\$/ton):

MARGINAL COST (SAVINGS) OF SUBSTITUTION (\$/ton):

MATERIALS RECOVERY:

MUNICIPAL SOLID WASTE (MSW):
Materials that are separated from Residential MSW as household hazardous wastes for separate collection and treatment. Such materials may include paints and solvents, pesticides, herbicides, and propane tanks.

A practice of using several (i.e., two or more) alternative waste management techniques to treat, process, and/or dispose of the Municipal Solid Waste stream. Alternative waste management techniques include source reduction, recycling, composting, combusting, and landfilling.

Portion of the MSW stream for which the cost of collecting, transferring, hauling, processing, combusting, marketing, and/or disposing of such waste is known or can be reasonably estimated.

The cost (savings) of managing an additional ton of MSW, garbage, trash, recyclables, or yard waste.

The net cost (savings) of managing an additional ton of recyclables or yard waste less the savings (cost) of managing one less ton of garbage.

A term describing the extraction and utilization of materials from a waste stream.

Non-hazardous solid wastes generated by households, commercial and business establishments, institutions, and light industry; it excludes industrial process wastes, agricultural wastes, mining wastes, construction and demolition debris, offal, sludges, and ashes, except ashes derived from the combustion of MSW. In practice, 
specific definitions vary across jurisdictions.

PROGRAM INCREMENTAL COST (SAVINGS) (\$/year):

RECOVERED MATERIALS:

RECYCLABLE MATERIALS OR RECYCLABLES:

RECYCLE:

RESIDENTIAL MSW:

RESIDUE:

RESOURCE RECOVERY:
The difference between the cost of managing MSW with or without a particular program (e.g., curbside collection, processing, and marketing of recyclables.)

Recyclable materials that are recovered from MSW and may also include some contamination.

Materials that still have useful physical or chemical properties after serving their usefulness for a given individual or firm and can, therefore, be reused or recycled for the same or other purposes.

To convert discarded materials into useful products through reuse and remanufacturing.

Municipal solid waste that is generated by households.

That portion of processed MSW that is ultimately disposed of in a landfill.

A term describing the extraction and utilization of energy or materials from a waste stream.

A material that is used in place of a primary or raw material in manufacturing a product; often handled by dealers and brokers in "secondary markets." 
The delivery of MSW or other wastes to an integrated municipal solid waste management system by a private firm or individual that is not under contract to a municipality, authority, utility, or other public entity responsible for municipal solid waste management to make such deliveries.

TOTAL NET COST OR TOTAL COST (\$/year):

YARD WASTE:

WHITE GOODS:
The aggregate of all expenditures incurred to manage municipal solid waste, inclusive of general and administrative, planning, capital, collection, processing, transfer and haul, marketing, promotion and education, and disposal costs, less any revenues derived from resource recovery activities.

Vegetative material that is.segregated from the MSW stream for separate collection and/or processing, including grass, prunings, plants, and small tree limbs, but excluding tree stumps, land-clearing debris, and other large vegetative matter.

That portion of bulky waste which consists of large appliances, such as refrigerators, stoves, washing machines, and dryers. 


\section{Appendix B - Allocation of Costs and Results Tables}

The allocation procedures used to determine the cost incurred for various functions or types of waste are presented in this Appendix. The procedure involves the following steps: (1) classifying each expenditure by function; (2) determining expenditures that are totally or partially "applicable" or "not applicable" to the 59,907 tons of Analyzed MSW; (3) allocating expenditures related to the Analyzed MSW to the management of garbage, recyclables, yard waste, and non-recyclable bulky waste; and (4) allocating City costs to manage, exclusive of collection costs, HHW. Each of these steps is discussed below. The resulting allocations of the total net cost of $\$ 8.27$ million (see Appendix C) are provided in Table B.1 at the end of this Appendix.

\section{B.1 Step 1: Classification of Expenditures by Function}

The expenditures incurred by the City of Springfield, provided in Table C.1 of Appendix C, were classified into the following functional areas: General \& Administrative (G\&A); Collection; Facilities; Landfill; Promotion, Education, and Public Relations; Miscellaneous Recycling; and Other. The details of the Solid Waste Division Job Cost Data shown in Table C.1 can be found in Table C.3.

The results of the classification are presented in Tables B.2 through B.10. For example, the $\$ 783,558$ Bondi's Island Landfill contractor fee listed in Table C. 1 is classified as a landfill expense and listed in Table B.5: Landfill Costs (FY 1993) as the Resource Control, Inc. landfill fee. Similarly, the $\$ 1,080,649$ garbage collection cost listed in Table C.3 is classified as a collection expense and listed in Table B.3: Collection Costs (FY 1993).

Capital Costs and Revenues for each function are provided separately in Tables B.8 and B.10, respectively. For example, the $\$ 354,256$ net MRF Capital and O\&M cost listed in Table C.1 is disaggregated and classified as a $\$ 287,331 \mathrm{MRF}$ O\&M Cost in Table B.4; a $\$ 173,705 \mathrm{MRF}$ Capital Cost in Table B.8; and a $\$ 106,780$ MRF Revenue in Table B.10 (i.e., $\$ 354,256=$ $\$ 287,331+\$ 173,705-\$ 106,780)$.

\section{B.2 Step 2: Determine "Applicable" and "Not Applicable" Expenses}

About $\$ 1.20$ million of the $\$ 8.27$ million total net cost is classified as being "not applicable" to the management of the 59,907 tons of Analyzed MSW. The $\$ 1.20$ million primarily represents the costs to: (1) dispose of 23,800 tons of as-received ash generated from MSW delivered to the WTE facility by other Cities and about 15,600 tons of other waste (e.g., sludge, unsold sludge compost, and street sweepings) delivered to the Bondi's Island Landfill by the City; (2) sweep city streets, clean catch basins, and participate in special events; (3) operate and maintain a portion of the compost operation that is attributable to self-hauled and imported yard waste; and (4) manage the approximately 15 tons of HHW.

Each expense or revenue in Tables B.2 through B.10 was first reviewed to determine if it could be classified as being either "applicable" or "not applicable." For example, 100 percent of the Yard Waste Drop-Off cost in Table B.3 is not applicable to the management of the Analyzed MSW because this expense is related to yard waste that is self-hauled. On the other hand, 100 percent of the WTE facility O\&M cost in Table B.4 is classified as "applicable."

Only a portion of some costs, such as the Bondi's Island Landfill contractor fees and the costs of 
the compost operation, were classified as being "not applicable" and "applicable." A detailed discussion of the method used to apportion the Bondi's Island Landfill contractor fee is provided in Section C.1.3.1 of Appendix C. In general, the portion of this fee that was classified as being applicable to the management of the Analyzed MSW is based on the percent of ash generated from the City's garbage processed at the WTE facility to the total tonnage of waste disposed of at the landfill. Similarly, the portion of the composting operation costs that is classified as not applicable to the management of the Analyzed MSW is equal to the percentage of yard waste that was self-hauled or imported. For example, 16.1 percent (i.e., 1,308 divided by 8,122 ) of the yard waste processed by the City was either self-hauled or imported from the Town of Agawam. The $\$ 7,017$ cost of the Composting Operation classified as being "not applicable" in Table B.4 is equal to about 16 percent of the $\$ 43,583$ total cost.

A portion of the G\&A expenses were allocated as being "not applicable" based on the percentage of non-G\&A expenses that was "not applicable."

\section{B.3 Step 3: Allocate Managed MSW Costs by Type of Waste}

The procedure to allocate the $\$ 7.07$ million cost to manage the 59,907 tons of Analyzed MSW to the cost of managing garbage, recyclables, yard waste, and non-recyclable bulky waste is similar to the procedure used to determine which costs or proportion of costs were "applicable" or "not applicable." The footnotes in Tables B.2 through B.10 describe the variables used to determine the portion of these costs apportioned to the various types of MSW. First, specific costs that are 100 percent associated with the various types of MSW were identified and allocated accordingly. Generally, the Job Cost data were sufficient to allocate most Solid Waste Division costs by type of MSW (see Table C.3 of Appendix C).

Some expenses were allocated to more than one type of waste. For example, a portion of the $\$ 245,820$ O\&M cost of the garbage/yard waste collection vehicles shown in Table B.3 was allocated to the collection of garbage, yard waste, and recyclables. The DPW reported that 69,502.2 labor hours were spent collecting garbage and 4,999.5 labor hours were spent collecting yard waste. Assuming that these hours reflect the time the garbage/yard waste vehicles spend collecting each type of waste, 93.4 percent of the time these vehicles were used to collect garbage and 6.6 percent of the time they were used to collect yard waste. The $\$ 16,187$ vehicle O\&M cost attributed to yard waste is equal to about 6.6 percent of the total cost (i.e., 245,820 times 0.066). A portion of the garbage collection cost was apportioned to collection of recyclables, because some materials are recovered from the garbage delivered to the WTE facility. Of the 44,707 tons of garbage delivered to the WTE facility about 23 tons of metals, or 0.051 percent, were recovered for recycling. The portion of the garbage vehicle $O \& M$ cost attributable to recyclables was calculated as $\$ 117$, which is equal to about 93.4 percent of the total cost of $\$ 245,820$ times 0.051 percent. The balance of $\$ 229,516$ (i.e., $\$ 245,820$ - $\$ 16,187$ - $\$ 117$ ) is attributed to the collection of garbage. The same method was used to allocate the Capital Cost of the garbage/yard waste vehicles.

The WTE facility O\&M cost shown in Tables B.4 was also allocated between garbage and recyclables based on the 0.051 percent of the waste processed at the facility that was recovered for recycling. Of the $\$ 2,798,606$ total cost, $\$ 1,427$ (i.e., $\$ 2,798,606$ times 0.051 divided by 100 ) was allocated to the cost of managing recyclables, and the balance of $\$ 2,797,207$ was allocated to the management of garbage. 
The O\&M and Capital costs of the bulky waste vehicles were allocated between recyclables and bulky waste based on the ratio of white goods collected to the total tonnage of bulky waste collected. For example, of the total cost of $\$ 6,821$ for the Bulky Waste Vehicle O\&M listed in Table B.3, $\$ 2,638$ (i.e., $\$ 6,821$ times the ratio of 509 to 1,316 ) is attributable to the collection of recyclables (i.e., white goods) and $\$ 4,183$ (i.e., $\$ 6,821$ minus $\$ 2,638$ ) is attributable to the collection of non-recyclable bulky waste.

G\&A expenses are allocated in direct proportion to the level of non-G\&A expenses.

\section{B.4 Step 4: Allocate Costs to Manage HHW}

The costs that can be 100-percent attributed to HHW management activities were allocated to the management of HHW. For example, the fees paid to Green Paint Co. and Clean Harbor listed in Table B.3 are entirely allocated to the management of HHW. G\&A expenses were allocated to HHW in direct proportion to the non-G\&A expenses allocated to HHW. 
Table B.1: Springfield's Integrated Municipal Solid Waste Management Costs (FY 1993)

\begin{tabular}{|c|c|c|c|c|c|c|c|c|}
\hline Costs & Itemized & $\begin{array}{c}\text { Not } \\
\text { Applicablo }\end{array}$ & $\begin{array}{c}\text { Analyzad } \\
\text { MSW }\end{array}$ & Garbage & Recyclables & Yard Waste & Bulky & HHW \\
\hline \multicolumn{9}{|l|}{ General \& Administrative } \\
\hline \begin{tabular}{|l} 
Operating \& Maintenance \\
\end{tabular} & $\$ 1,228,978$ & $\$ 163,142$ & $\$ 1,065,836$ & $\$ 826,288$ & $\$ 158,629$ & $\$ 57,515$ & $\$ 23,410$ & $\$ 4,959$ \\
\hline Subtotal & $1,360,668$ & 180,635 & $1,180,034$ & 914,885 & 175,554 & 63,682 & 25,920 & 5,491 \\
\hline \multicolumn{9}{|l|}{ Collection } \\
\hline Operating \& Maintenance & $2,310,284$ & 36,231 & $2,274,053$ & $1,661,194$ & 361,500 & 179,255 & 72,115 & 28,146 \\
\hline Capital Costs & 489,532 & & 489,532 & 344,272 & 118,628 & 20,043 & 6,588 & \\
\hline Subtotal & $2,799,816$ & 36,231 & $2,763,585$ & $2,005,466$ & 480,128 & 199,298 & 78,703 & 28,146 \\
\hline Capital Costs & $2,047,696$ & 19,460 & $2,028,236$ & $1,790,412$ & 173,705 & 64,119 & & \\
\hline Subtotal & $5,216,367$ & 32,163 & $5,184,204$ & $4,587,619$ & 466,294 & 130,319 & 0 & $\mathrm{o}$ \\
\hline \multicolumn{9}{|l|}{ Landfill } \\
\hline \begin{tabular}{|l|} 
Operating \& Maintenance \\
\end{tabular} & $1,013,808$ & 661,318 & 352,490 & 298,324 & & & 54,166 & \\
\hline Capital Costs & 159,807 & & 159,807 & 159,807 & & & & \\
\hline Subtotal & $1,173,616$ & 661,318 & 512,297 & 458,132 & 0 & 0 & 54,166 & $\overline{0}$ \\
\hline Promotion/Education/PR & 150 & & 150 & & 150 & & & \\
\hline Misc. Recycling Expenses & 3,933 & & 3,933 & & 3,933 & & & \\
\hline \multicolumn{9}{|l|}{ Gross Costs } \\
\hline Revenues & $(2,555,370)$ & 609 & $(2,554,760)$ & $(2,437,680)$ & $(113,906)$ & $(3,174)$ & 0 & $\bar{c}$ \\
\hline \begin{tabular}{|l} 
NET COST \\
\end{tabular} & $\$ 8,272,291$ & $\$ 1,106,588$ & $\$ 7,165,703$ & $\$ 5,604,682$ & $\$ 1,012,153$ & $\$ 390,125$ & $\$ 158,789$ & $\$ 33,637$ \\
\hline NET COST PER TON (\$/ton) & & & 120 & 125 & 136 & 57 & 197 & \\
\hline
\end{tabular}

Allocation of Costs: See Tables 82 through 810. 
Table B.2: General and Administration Costs (FY 1993)

\begin{tabular}{|c|c|c|c|c|c|c|c|c|}
\hline Costs & Itemized & $\begin{array}{c}\text { Not } \\
\text { Applicable }\end{array}$ & $\begin{array}{c}\text { Analyzed } \\
\text { MSW }\end{array}$ & Garbage & Recyclables & Yard Waste & Bulky & HHW \\
\hline City Indirect & $\$ 168,000$ & $\$ 22,507$ & $\$ 145,493$ & $\$ 113,994$ & $\$ 20,335$ & $\$ 7,935$ & $\$ 3,230$ & $\$ 684$ \\
\hline DPW Indirect & 168,670 & 22,597 & 146,073 & 114,449 & 20,416 & 7,966 & 3,243 & 687 \\
\hline DEP Indirect (MRF) & 11,230 & & 11,230 & & 11,230 & & & \\
\hline Solid Waste & 863,109 & 115,631 & 747,478 & 585,652 & 104,473 & 40,766 & 16,592 & 3,515 \\
\hline Vehicle O\&M & 17,969 & 2,407 & 15,562 & 12,193 & 2,175 & 849 & 345 & 73 \\
\hline & & & & & & & & \\
\hline & & & & & & & & \\
\hline & & & & & & & & \\
\hline & & & & & & & & \\
\hline & & & & & & & & \\
\hline & & & & & & & & \\
\hline & & & & & & & & \\
\hline TOTAL & $\$ 1,228,978$ & $\$ 163,142$ & $\$ 1,065,836$ & $\$ 826,288$ & $\$ 158,629$ & $\$ 57,515$ & $\$ 23,410$ & $\$ 4,959$ \\
\hline
\end{tabular}

in

Allocation of Costs:

1. Proportion of G\&A costs allocated to "Not Applicable" is about 14.7 percent of the total costs. This is the fraction of total non-G\&A costs allocated to "Not Applicable."

2. Allocation of "Analyzed MSW" G\&A Expenses is based on fraction of all other non-G\&A expenses allocated to Garbage, Recyclables, Yard Waste, and Bulky Waste.

3. Allocation of G\&A costs allocated to "HHW" is about .41 percent of the total costs. This is the fraction of total non-G\&A costs allocated to total non-G\&A HHW costs. 
Table B.3: Collection Costs (FY 1993)

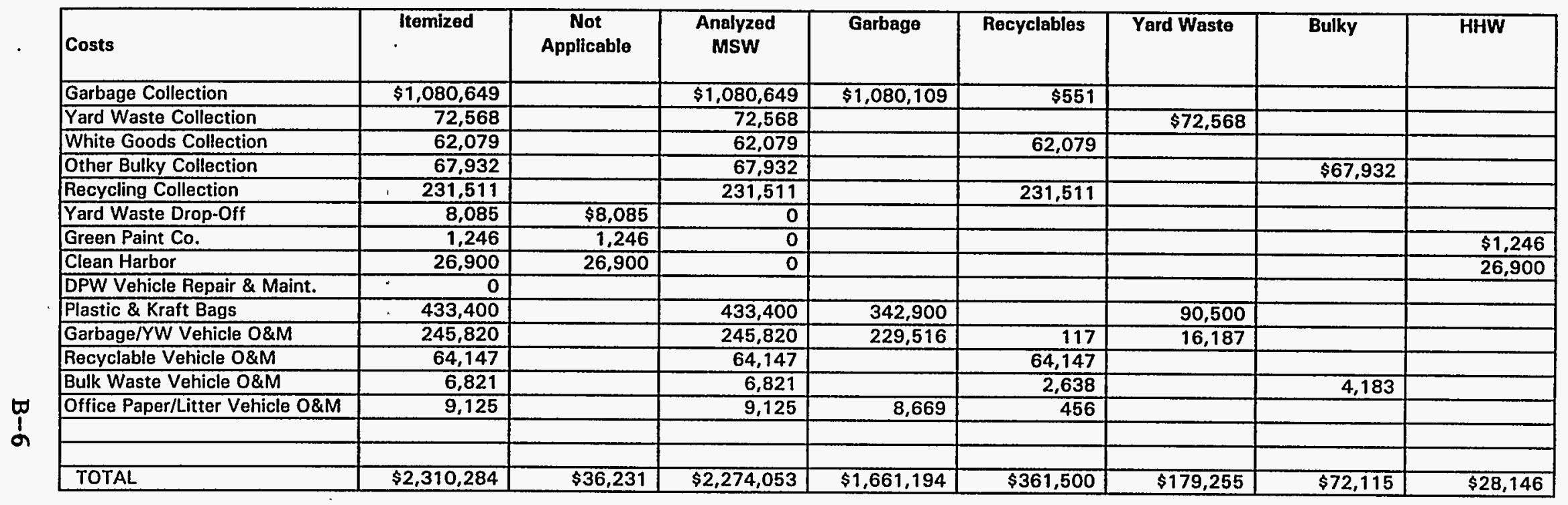

Allocation of Costs:

1. Most allocations based on Job Cost Data allocations.

2. The allocation of Garbage Collection O\&M between Garbage and Recyclables is based upon the percentage of MSW delivered to the WTE facility that is recovered as Recyclables.

3. The allocation of Garbage/YW Vehicle O\&M is based on fraction of total labor hours (i.e., truck hours) spent on garbage or yard waste collection.

4. The bulk waste vehicle $O \& M$ is allocated between non-metalic bulky waste and white goods based on tonnage. 
Table B4: Facilities (Processing) Costs (FY 1993)

\begin{tabular}{|c|c|c|c|c|c|c|c|c|}
\hline Costs & Itemized & $\begin{array}{c}\text { Not } \\
\text { Applicable }\end{array}$ & $\begin{array}{l}\text { Analyzed } \\
\text { MSW }\end{array}$ & Garbage & Recyclables & Yard Waste & Bulky & HHW \\
\hline Materials Recovery Facility & $\$ 287,331$ & & $\$ 287,331$ & & $\$ 287,331$ & & & \\
\hline Composting Operation & 43,583 & $\$ 7,017$ & 36,566 & & & $\$ 36,566$ & & \\
\hline Waste-to-Energy Facility & $2,798,606$ & & $2,798,606$ & $\$ 2,797,207$ & 1,427 & & & \\
\hline White Goods Preparation & 3,831 & & 3,831 & & 3,831 & & & \\
\hline Compost Operation Equip. O\&M & 35,320 & 5,687 & 29,633 & & & 29,633 & & \\
\hline & & & & & & & & \\
\hline & & $\dot{\Sigma}$ & & & & & & \\
\hline & & & & & & & & \\
\hline & & & & & & & & \\
\hline & & & & & & & & \\
\hline & & & & & & & & \\
\hline TOTAL & $\$ 3,168,671$ & $\$ 12,703$ & $\$ 3,155,968$ & $\$ 2,797,207$ & $\$ 292.589$ & $\$ 66.200$ & $\$ 0$ & 50 \\
\hline
\end{tabular}

$\stackrel{1}{1}$ Allocation of Costs:

1. The allocation of the Yard Waste Composting cost is allocated between "Not Applicable" and "Analyzed" is based fraction of tonnage that is self-hauled or imported. 
Table B.5: Landfill Costs (FY 1993)

\begin{tabular}{|c|c|c|c|c|c|c|c|c|}
\hline Costs & Itemized & $\begin{array}{c}\text { Not } \\
\text { Applicable' }\end{array}$ & $\begin{array}{c}\text { Analyzed } \\
\text { MSW }\end{array}$ & Garbage & Recyclables & Yard Waste & Bulky & HHW \\
\hline & & & & & & & & \\
\hline Bulky Wastes & $\$ 54,166$ & & $\$ 54,166$ & & & & $\$ 54,166$ & \\
\hline Resource Control, Inc & 783,558 & $\$ 589,742$ & 193,816 & $\$ 193,816$ & & & & \\
\hline Landfill Operation Operations & 9,127 & & 9,127 & 9,127 & & & & \\
\hline Methane Gas Collection & 4,436 & 4,436 & 0 & & & & & \\
\hline Landfill Expansion & 38,832 & 38,832 & 0 & & & & & \\
\hline Suspect Water Break & 271 & 271 & 0 & & & & & \\
\hline New Monitoring Wells & 313 & 313 & 0 & & & & & \\
\hline General Maintenance (W Sprg) & 514 & 514 & 0 & & & & & \\
\hline Storm Water Drain (W Sprg) & 27,210 & 27,210 & 0 & & & & & \\
\hline Bondi's Island Landfill & 4,300 & & 4,300 & 4,300 & & & & \\
\hline \begin{tabular}{|l|} 
Closure \\
\end{tabular} & 91,081 & & 91,081 & 91,081 & & & & \\
\hline TOTAL & $\$ 1,013,808$ & $\$ 661,318$ & $\$ 352,490$ & $\$ 298,324$ & $\$ 0$ & $\$ 0$ & $\$ 54,166$ & $\$ 0$ \\
\hline
\end{tabular}

Allocation of Costs:

1. Allocation for landfill disposal fees paid to Resource Control for other wastes, i.e., allocated to "Not Applicable" is based on tonnage. 
Table B.6: Promotion/Education/Public Relations Costs (FY 1993)

\begin{tabular}{|c|c|c|c|c|c|c|c|c|}
\hline Costs & Itemized & $\begin{array}{c}\text { Not } \\
\text { Applicable }\end{array}$ & $\begin{array}{l}\text { Analyzed } \\
\text { MSW }\end{array}$ & Garbage & Recyclables & Yard Waste & Bulky & HHW \\
\hline Education & $\$ 150$ & & $\$ 150$ & & $\$ 150$ & & & \\
\hline & & & & & & & & \\
\hline & & & & & & & & \\
\hline & & & & & & & & \\
\hline & & & & & & & & \\
\hline & & & & & & & & \\
\hline & & & & $\overline{-}$ & & & & \\
\hline & & & & & & & & \\
\hline & & & & & & & & \\
\hline TOTAL & $\$ 150$ & $\$ 0$ & $\$ 150$ & $\$ 0$ & $\$ 150$ & $\$ 0$ & \$0 & $\$ 0$ \\
\hline
\end{tabular}

$\underset{1}{b}$ 


\begin{tabular}{|c|c|c|c|c|c|}
\hline 05 & $0\}$ & $0 \$$ & $\varepsilon \varepsilon 6^{\prime} \varepsilon \$$ & $0 \$$ & $\varepsilon \varepsilon$ \\
\hline & & & & & \\
\hline & & & & & \\
\hline & & & & & \\
\hline & & & & & \\
\hline & & & & & \\
\hline & & & & & \\
\hline & & & & & \\
\hline & & & & 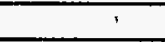 & \\
\hline & & & & & \\
\hline & & & & & \\
\hline & & & & & \\
\hline & & & $\varepsilon \varepsilon 6^{\prime} \varepsilon \$$ & & $\varepsilon \varepsilon$ \\
\hline MHH & Ax|ng & O1S8M PAEA & sө|q®|כКэө女 & e6equeg & \\
\hline
\end{tabular}

\begin{tabular}{|l|l|}
\hline & 0 s \\
\hline & \\
\hline & \\
\hline & \\
\hline & \\
\hline & \\
\hline
\end{tabular}

\begin{tabular}{|c|c|c|}
\hline & $\varepsilon \varepsilon 6^{\prime} \varepsilon \dot{s}$ & 78101 \\
\hline & & \\
\hline & & \\
\hline & & \\
\hline & & \\
\hline & & \\
\hline & & \\
\hline & & \\
\hline & $\varepsilon \varepsilon \sigma^{\prime} \varepsilon s$ & |Eнданар \\
\hline & pez̨ume\}! & sisc \\
\hline
\end{tabular}

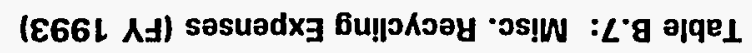


Table B.8: Capital Costs (FY 1993)

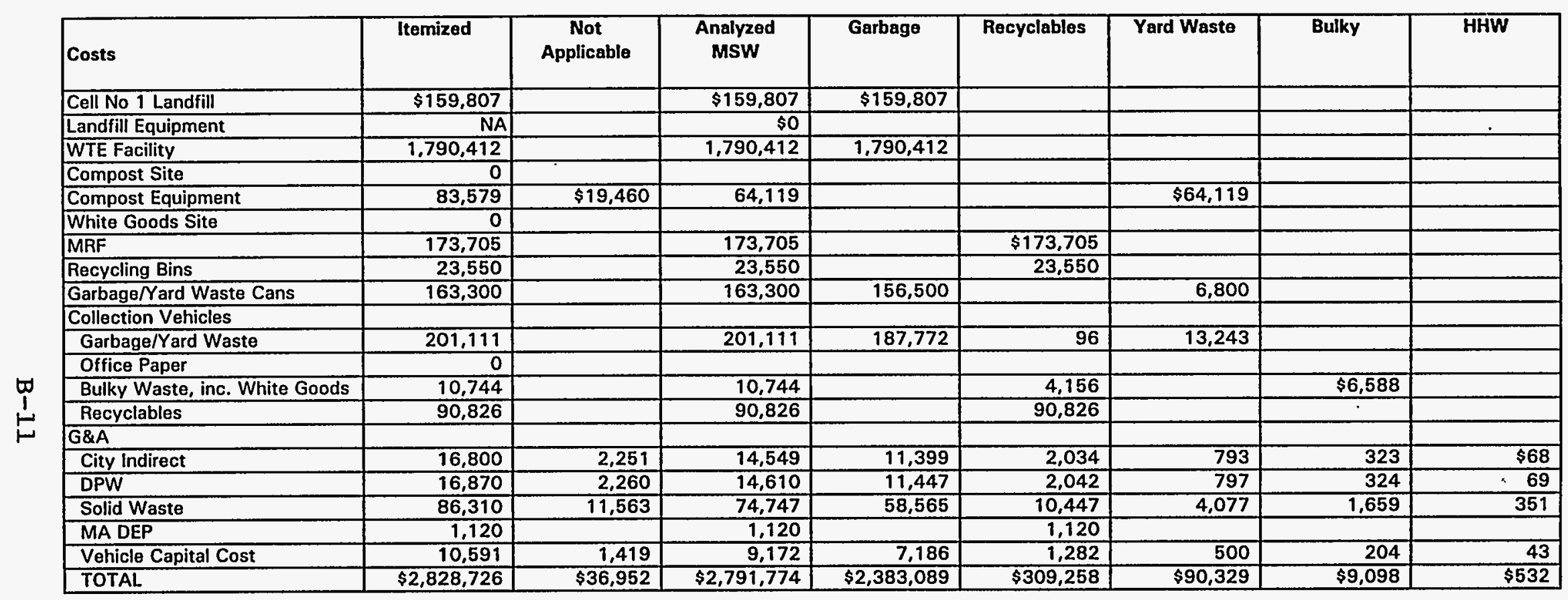

Allocation of Costs:

1. The allocation of Garbage Collection Capital Cost between Garbage and Recyclables is besed upon the percentage of MSW delivered to the WTE facility that isrecovered as Recyclables.

2. The allocation of Garbage/YW Vehicle Capital Cost is based on fraction of total labor hours (i.e., truck hours) spent on garbage or yard waste collection.

3. The bulk waste vehicle Capital Cost is allocated between non-metalic bulky waste and white goods based on tonnage.

4. It is assumed that 33.3 percent (i.e., four months) of the Capital Cost of the front end losder and dump truck used at the compost site is allocated to snow removal, i.e., is "Not Applicable."

5. The Compost Equipment is further allocated between "Not Applicable" and "Analyzed MSW" based on fraction of tonnage that is self-hauled or imported. 


\begin{tabular}{|c|c|c|c|c|c|c|c|c|}
\hline $0 \$$ & $0 \leqslant$ & $0 \$$ & $0 \$$ & $09 Z^{\prime} 9 \angle s$ & $09 Z^{\prime} 9 \angle S$ & $098^{\prime} 961 \$$ & OLL'ELZ\$ & $7 \forall 101$ \\
\hline & & & & & & & & \\
\hline & & & & & & & & \\
\hline & & & & & 0 & $\angle 69$ & $\angle 69$ & spunodg 'abedeg ajueuazu!eW \\
\hline & & & & & 0 & $\angle D L$ & $\angle t$ & Eu!deaMS 107 Gu!yded \\
\hline & & & & & 0 & $t+L^{\prime} L$ & $\nabla t L^{\prime} L$ & SEad U Uo!̣endasuoJ Gu!ueaIJ \\
\hline & & & & & 0 & $06 L^{\prime} \mathrm{L}$ & $06 L^{\prime} L$ & 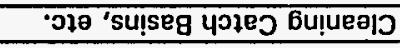 \\
\hline & & & & $09 Z^{\prime} 9 \angle S$ & $09 Z^{\prime} 9 L$ & 0 & $09 Z^{\prime} 9 L$ & folfuoo del1!? \\
\hline & & & & & 0 & $6 L L^{\prime} 8 L$ & $6 L L^{\prime} 8 L$ & Bu!uea|ว 107 \\
\hline & & & & & 0 & $09 L$ & $09 L$ & д!eday asuag 'os! W \\
\hline & & & & & 0 & $90 L^{\prime} 9$ & $90 L^{\prime} 9$ & suleday 8 Gu!Yoled ledouog \\
\hline & & & & & 0 & $80 l^{\prime} 60 t$ & $8+l^{\prime} 601$ & Bu!uealo teans \\
\hline & & & & & 0 & 769 & 669 & 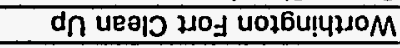 \\
\hline & & & & & 0 & $8 \angle Z^{\prime} 6$ & $8 \angle Z^{\prime} 6$ & 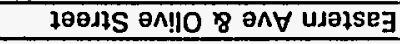 \\
\hline & & & & & 0 & GEZ L & $g \varepsilon Z^{\prime} L$ & isejyearg axpoued \\
\hline & & & & & 0 & 821 & 821 & 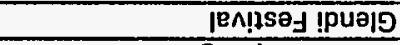 \\
\hline & & & & & $0 \$$ & DOL'LS & $\Rightarrow 0 L^{\prime} L S$ & 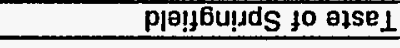 \\
\hline MHH & O1SBM PJEA & Ay|ng & se|qujohsoy & өвеquag & 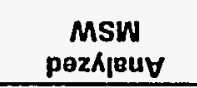 & $\begin{array}{c}\text { ofqBojןddy } \\
\text { 20N }\end{array}$ & pez!uev|| & \\
\hline
\end{tabular}


Table B.10: Resource. Recovery Revenues (FY 1993)

\begin{tabular}{|c|c|c|c|c|c|c|c|c|}
\hline Costs & Itemized & $\begin{array}{c}\text { Not } \\
\text { Applicable }\end{array}$ & $\begin{array}{c}\text { Analyzed } \\
\text { MSW }\end{array}$ & Garbage & Recyclables & Yard Waste & Bulky & HHW \\
\hline Materials Recovery Facility & $\$ 106,780$ & & $\$ 106,780$ & & $\$ 106,780$ & & & \\
\hline White Goods/Metal & 7,126 & & 7,126 & & 7,126 & & & \\
\hline Compost & 3,784 & $\$ 609$ & 3,174 & & & $\$ 3,174$ & & \\
\hline WTE Facility & $2,437,680$ & & $2,437,680$ & $\$ 2,437,680$ & & & & \\
\hline & & & & & & & & \\
\hline & & & & & & & & \\
\hline & & & & & & & & \\
\hline & & & & & & & & \\
\hline & & & & & & & & \\
\hline & & & & & & & & \\
\hline TOTAL & $\$ 2,555,370$ & $\$ 609$ & $\$ 2,554,760$ & $\$ 2,437,680$ & $\$ 113,906$ & $\$ 3,174$ & $\$ 0$ & $\$ 0$ \\
\hline
\end{tabular}

A. Allocation of Costs:

$\omega$ 1. The Compost revenues are allocated batween "Not Applicable" and "Analyzed MSW" based on fraction of tonnage that is self-haulod or imported. 


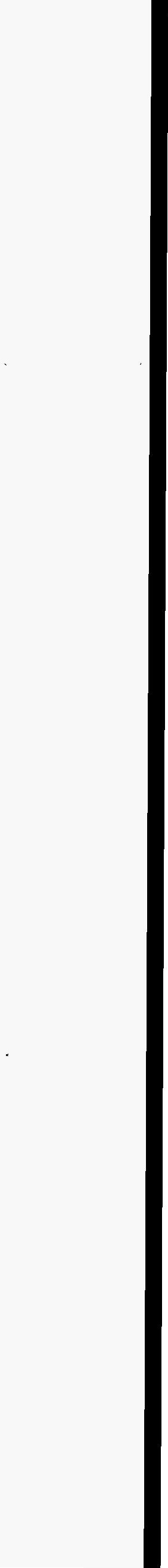




\section{Appendix C - Methodology, Assumptions, and Data Used to Calculate Costs}

The methodology, assumptions, and data used to calculate total, net, and incremental costs of managing MSW in Springfield, i.e., collecting, processing, composting, combusting, marketing recovered materials, and disposing of MSW are presented in this Appendix.

The costs of the Springfield IMSWM System are born by numerous City, state, and private entities. Springfield's DPW Solid Waste Division is primarily responsible for the day to day collection and management of MSW. Many services, such as vehicle and equipment maintenance, legal, procurement, and facilities maintenance are performed by other City departments and other services, such as the operation of the Bondi's Island landfill and the operation of the WTE facility, are provided by private contractors. The Commonwealth of Massachusetts pays all of the capital and operating costs of the MRF. Finally, the Commonwealth paid for the cost of the recycling bins while residents are responsible for purchasing kraft paper bags and/or cans for yard waste collection and plastic bags and/or cans for the collection of garbage.

Since MSW management in Springfield is paid from general revenues and is not treated as an enterprise system, a consolidated accounting of the costs of managing MSW in Springfield is not available. Rather CSI determined the total and net costs by compiling information provided by the City, Commonwealth, and private contractors as presented in Section C.1. The methodology to estimate program incremental costs is presented in Section C.2.

\section{C.1 Determining Total and Net Costs}

The FY 1993 total net cost of MSW management in Springfield was about $\$ 8.27$ million as shown in Table C.1. The derivation of this net cost is provided in subsections C.1.1 through C.1.9.

\section{C.1.1 Solid Waste Division Job Cost Data}

The derivation of the $\$ 2,823,338$ Solid Waste Job Cost Data expenses is presented in this subsection. All direct labor costs, rental equipment charges, and purchases of materials and services incurred by the City's DPW are charged to specific job cost accounts. Table C.2 is a summary of the charges made to the Solid Waste Division's job cost accounts in FY 1993. ${ }^{85}$ Adjusted Solid Waste Division operating expenses are provided in Table C.3. The adjustments made are discussed below.

\section{C.1.1.1 Fringe Benefits}

The labor costs reported in Table C.2 reflect both regular and overtime costs of DPW employees. Except for vacation, holiday, sick, jury duty, and other leaves, this data does not include the costs of any fringe benefits. The aggregate cost of the various leaves are reported for the Solid Waste Division and shown in Table C. 2 as a G\&A cost. The costs of other benefits such as insurance and retirement are not only excluded from these reported labor costs, but are not reported for the City as a whole. For example, the City manages its own retirement program and payments made

85 DPW, "Job Cost Summary Report," Computer Output, Account 0100433 \& 0100439 , pages 75 through 92, August 12, 1993. 
in FY 1993 were for current retirees, i.e., prior obligations, and do not necessarily reflect obligations being incurred for current employees. ${ }^{86}$

Because of the lack of reliable data for estimating the cost of fringe benefits the regular hour direct labor costs were increased by 35 percent to account for all fringe benefits, including vacations, holidays, and leaves. ${ }^{87}$ Thus, the $\$ 226,717$ cost for leaves shown in Table C.2 was eliminated and a fringe benefit column was added to Table C.3. The total fringe benefit are estimated to be about $\$ 498,900$. Therefore, the DPW's reported costs are increased by about $\$ 272,200$ (i.e., 498,903 minus 226,717 ) to account for the cost of insurance, retirement, and other miscellaneous fringe benefits.

\section{C.1.1.2 DPW Vehicle Repair \& Maintenance}

The Job Cost report indicated a labor cost of $\$ 8,930$ for DPW Vehicle Repair \& Maintenance. This charge was made to the Solid Waste Division because of a year end shortfall in the garage payroll budget. This cost is, therefore, more appropriately attributed to the DPW garage labor cost and not the Solid Waste Division. The labor costs to maintain solid waste management vehicles and equipment is explicitly accounted for later in this Appendix. Therefore, to avoid double counting, this cost was eliminated.

\section{C.1.1.3 Credit for Disposal of Waste at the WTE Facility by Other City Departments}

The Job Cost report shows a $\$ 24,146$ credit for the collection of household garbage. This credit is the payments from other City Departments (e.g., parks, public housing, and wastewater treatment) made to the DPW for the disposal of waste at the WTE facility. Similarly, a $\$ 3,350$ credit was included in the $\$ 2,595,166$ cost reported for the Waste-to-Energy facility in Table C.2. These credits were eliminated from the cost estimate since they reflect an intercity transfer of funds. The effect of the tonnage delivered to the WTE facility from other City Departments is explicitly accounted for in determining the costs attributed to Analyzed MSW.

\section{C.1.1.4 Elimination of Contracted Waste Management Services}

The City contracted for the disposal of bulky waste at a private landfill, the operation of the Bondi's Island landfill, and the disposal of MSW at the WTE facility. To ensure the proper application of these costs in this study, these expenses are explicitly treated in this analysis as discussed in subsequent sections of this Appendix. To avoid double counting these costs are not included in Table C.3.

The "Material/Services" costs eliminated from Table C. 2 in generating Table C.3 are $\$ 44,009$

${ }^{86}$ Discussion with James Fitchet, Senior Comptroller, DPW.

87 A 35 percent factor was used by the DPW to estimate Indirect Overhead expenses in 1990. See Departmental and Inter-Departmental Correspondence, City of Springfield, "Indirect Overhead Impact on Cost of Providing Services," James Fitchet, Comptroller, DPW, February 8, 1990. 
"Collection of Bulky Waste" cost; $\$ 47,233$ "Sanitary Landfill Operation" cost; ${ }^{88}$ and the $\$ 2,595,166$ "Energy Recovery Facility" cost. These Material/Service costs eliminated from Table C. 2 are not always the same as the contractor costs included in this analysis. For example, the $\$ 47,009$ Sanitary Landfill Operation cost listed in the Job Cost computer report was actually a net cost to the City, i.e., the revenues received for the disposal of other communities ash at the landfill were subtracted from the payments made to the landfill contractor. Such payments are not included in this analysis because they are charges for ash disposal services provided by the City and are not directly related to the costs of managing Springfield's MSW. ${ }^{89}$

\section{C.1.1.5 Reallocation of Consulting Fees and Elimination of Prior Year Expenses}

The Job Cost data allocated $\$ 13,042$ to the "Bondi's Island Sanitary Landfill' subaccount. Of this amount only $\$ 4,300$ was actually spent for consulting services related to the Cell \#1 of the landfill. The balance of $\$ 8,742$ was spent on consulting services related to the WTE facility. This amount was added to the $\$ 19,050$ shown as "Energy Recovery Facility Consulting Service" in Table C. 2 to obtain the $\$ 27,792$ figure shown in Table C.3.

The reported costs for FY 1993 included a labor cost of $\$ 2,668$ for a special event known as the "Taste of Springfield' which occurred between June 17, 1992 and June 22, 1992. Since this event occurred in fiscal year 1992 and not fiscal year 1993 it was eliminated when preparing Table C.3.

\section{C.1.2 Vehicle and Equipment O\&M and Capital Expenses}

The O\&M and Capital Expenses for the fleet vehicles and equipment used by the Solid Waste Division in FY 1993 are provided in Table C.4. The O\&M costs were generated from a computer printout entitled "Labor and Material Costs for A\&R ${ }^{90}$ Equipment for Fiscal Year 1993." The energy cost data was obtained from another computer printout entitled "Fuel Consumption for Selected Solid Waste Operations" and discussions with Mr. Michael Triggs of the City's DPW. This information was generated for this study from the City's fleet vehicle data base. The labor costs reported by the City were increased by 35 percent to account for the cost of fringe benefits.

The City had the purchase prices for most of the vehicles and equipment used in FY 1993. Because the City does not need to depreciate assets and because it does not maintain an asset account, these records were not complete. Specifically, the City did not know the original purchase prices of all of the Administration vehicles, the garbage trucks numbered 343 and 344 , the bulk waste collection truck numbered 324 , the compost operation dump truck numbered 276 , and the front end loader numbered 437. The purchase prices for these vehicles were estimated by CSI using data from vehicle manufacturers and costs of similar vehicles in other cities.

${ }^{88}$ Table C.2 shows a "Sanitary Landfill Operation" cost of $\$ 55,477$. Of this $\$ 47,233$ is the net payment made to the contractor. The balance of $\$ 8,245$ was for miscellaneous expenses related to the landfill operations including a $\$ 7,760$ consultant's fee.

89 The allocation of costs at the landfill, however, are affected by the amount of ash disposed of from other communities.

90 "A\&R" refers to Ashes and Rubbish 
Six of the recycling vehicle were purchased by the Commonwealth of Massachusetts and donated to the City. The DEP indicated that the cost of these vehicles ranged from $\$ 72,000$ to $\$ 75,000 .^{91}$ For this analysis the mid-point of this range was used, i.e., $\$ 73,500$. Another recycling vehicle, number 377, was purchased by the American Plastics Council and loaned to the City. The American Plastics Council indicated that the cost of this vehicle was about $\$ 80,000 .{ }^{92}$

The yard waste grinder was also purchased by the Commonwealth and donated to the City. The yard waste grinder was not placed into service until July 1993 (i.e., FY 1994). Because it was used to process yard waste collected in FY 1993 and stockpiled until the grinder was available, the cost of the yard waste grinder is included in this study.

The annual capital cost for these the vehicles and equipment were calculated using the procedures described in Appendix D. The calculation of the annual capital costs assumed a 7 percent cost of capital and a useful life of 9 years for all the vehicles and equipment.

The FY 1993 O\&M and Capital costs for the fleet vehicles and equipment was $\$ 776,054$ (i.e., 379,203 plus 396,851 ).

\section{C.1.3 Bondi's Island Landfill Costs and Bulky Waste Tip Fees}

\section{C.1.3.1 Bondi's Island Landfill Contractor Fees}

The Bondi's Island Landfill was operated by Resource Control, Inc. under contract to the City. ${ }^{93}$ Table C.5 is a summary of the monthly invoices submitted to the City by Resource Control in FY 1993. The total cost of the landfill services was $\$ 783,558 . .^{94}$

In FY 1993 the contractor was paid a fix annual operating fee of $\$ 273,000$ and a $\$ 89,250$ annual environmental monitoring fee. In addition, the contractor received a variable fee of $\$ 13.08 \mathrm{per}$ ton. Except for the ash from the WTE facility, the variable fee was applied to the as-received tonnage. The payments for ash disposal were based on dry tons. The tonnages disposed of at the Bondi's Island Landfill in FY 1993 are provided in Table C.6.

The "Deduction per Bid Item A-1" line in Table C.5 reflects a savings in ash disposal costs. Because there was limited ash storage capacity at the WTE facility prior to October 1992, the landfill had to remain open for extended hours to receive ash. An ash storage building was completed at the WTE in October 1992, eliminating the need for the extra hours of operation at the landfill. Thus, an additional cost of $\$ 7,962.50$ per month (i.e., the value of the Bid Item A-1

${ }^{91}$ Telephone conversation with Susan Cascino, Grant Manager, Solid Waste Recycling Grant Program, Massachusetts Department of Environmental Protection, June 1994.

92 Telephone conversation with Ron Perkins, American Plastics Council, May 1994.

${ }^{93}$ Resource Control, Inc. was purchased by United Waste Systems, Inc. who is the current operator of the landfill.

94 Resource Control, Inc., Invoices from July 1992 through June 1993. 
credit) charged in July, August, and September as part of the Base Operating Fee is attributed to the disposal of ash.

In this analysis it is assumed that the portion of the Base Operating Fee and the Environmental Monitoring Fee attributable to ash disposal is equal to the percentage, on an as-received basis, of the tons of ash relative to the total tonnage of waste disposed of at the landfill. On an as-received basis, ash is 71.1 percent of the waste disposed of at Bondi's Island by the contractor, i.e., 38,375 divided by 53,970 (see Table C.6). The Base Operating Fee less the $\$ 7,962.50$ per month additional charge for ash disposal was $\$ 177,450$ (i.e., 273,000 minus 12 times $7,962.50$ ). Of this amount $\$ 126,177$ is estimated to be attributed to ash disposal, i.e., about 71.1 percent of $\$ 177,450$. Similarly, the amount of the Environmental Monitoring Fee attributable to ash disposal is estimated to be about 71.1 percent of the total annual fee or $\$ 63,462$ (i.e., about 71.1 percent of $\$ 89,250$ ). Therefore, of the $\$ 783,558$ total amount paid to the contractor, $\$ 502,524$ is attributable to the disposal of ash. This is comprised of $\$ 126,177$ of the Base Operating Fee, $\$ 63,462$ of the Environmental Monitoring Fee, $\$ 23,888$ (i.e., 7,962.50 times 3) for the extra hours of operation in July, August, and September, and the $\$ 288,998$ variable fee for the disposal of ash.

In FY 1993 the City's DPW delivered about 38.6 percent (i.e., 44,707 divided by 115,916) of the MSW combusted at the WTE facility. Therefore, about 38.6 percent of the $\$ 502,524$ ash disposal cost, or $\$ 193,816$ is attributable to the disposal of Springfield's MSW. This $\$ 193,816$ figure is used as the Resource Control, Inc. fee for Analyzed MSW in Table B.5 of Appendix B.

\section{C.1.3.2. Capital Cost of the Bondi's Island Landfill}

The methodology used to calculate the $\$ 159,807$ capital cost attributed to the disposal of ash generated from the City's Garbage is provided below. The information presented in this section was obtained from the following information provided by the City's DPW: (1) "Bondi's Island Sanitary Landfill - Design \& Construction Contract with RCI, Computer Printout, December 17, 1991; (2) "Bondi Island, Springfield, MA - Remaining Landfill Capacity," Capacity Reported as of: 01-Jan-94; and "Background of Operations at Bondi Island Sanitary Landfill."

From 1984 through 1989 Cell \#1 and the West Springfield section of the Bondi's Island Landfill was designed and constructed for a total cost of $\$ 5,617,356$. Progress payments from 1984 through 1989 were escalated to the end of 1992 (i.e., the mid-point of FY 1993) using an assumed cost of capital of 7 percent. ${ }^{95}$ The resulting FY 1993 value of the investment in the landfill was $\$ 7,881,784$. A total of 38 acres were developed of which 52.6 percent (i.e., 20 acres) was for Cell \#1. The design cost of Cell \#1 of $\$ 439,801$ is calculated as 52.6 percent of the escalated total design cost of $\$ 836,124$. This is added to the escalated construction cost of Cell \#1 of $\$ 5,296,814$ to obtain a total design and construction cost of Cell \#1 of $\$ 5,736,615$.

The total capacity of Cell \#1 is about 611,000 cubic yards. The FY 1993 capital cost per cubic yard of the Bondi's Island Landfill is $\$ 9.39$ (i.e., 5,736,615 divided by 611,000 ). The total amount of as-received ash disposed of at the landfill was 38,375 as indicated in Table C.6. About 38.6 percent (i.e., 44,707 divided by 115,916 ) of this ash, or about 14,800 tons, is attributable

95 The calculation of the capital cost of the landfill considers the development and construction of the landfill as an investment that increases in value at the City's cost of capital. 
to the City's Garbage combusted at the WTE facility. Using a bulk density of ash of approximately one ton per cubic yard, and assuming that cover material consumes about 15 percent of the landfill volume, the capital cost at the landfill is $\$ 159,807$, (i.e., about 14,800 times 1.15 times 9.39 ).

\section{C.1.3.3 Bondi's Island Landfill Closure and Post-Closure Monitoring Costs}

The City estimated the 1991 closure cost for the Bondi's Island Landfill, Cell \#1 to be $\$ 2.0$ million, i.e., $\$ 100,000$ per acre. This cost was taken from the Massachusetts Department of Environmental Protection "Landfill Assessment and Closure Training Manual," published by the Division of Solid Waste Management in August 1991..$^{96}$ Escalating this cost at 4\% per year for 2 years results in an estimated 1993 closure cost of $\$ 2.16$ million. This represents a closure cost of $\$ 3.54$ per cubic yard for the 611,000 cubic yard of capacity of Cell \#1.

If the City established an escrow account and contributed about $\$ 3.54$ for each cubic yard consumed in FY 1993 and for each subsequent year deposited an additional amount equal to the escalated closure cost per cubic yard times the cubic yards consumed, and if the interest earned on the invested funds was at least as great as the annual rate of increase in the closure cost, then the funds in the escrow account would be sufficient to pay for the escalated cost of closure when the landfill ready to be closed. In this analysis the cost of closure is calculated to be the FY 1993 amount that would be required to be deposited in such an escrow account.

The ash disposed of in Cell \#1 attributable to the City's Garbage combusted at the WTE facility, including the required cover material, was about 17,020 cubic yards (i.e., 14,800 times 1.15). The estimated FY 1993 closure cost is, therefore, about $\$ 60,300$ (i.e., about 17,020 times $\$ 3.54$ ).

The City also estimated the 1991 cost of post-closure monitoring to be $\$ 95,000$ per year. If the City were to establish an escrow account that would be sufficient to cover the post-closure costs for 30 years, the fund, in 1993 dollars, assuming an escalation of 4 percent and a cost of capital of 7 percent, would be about $\$ 2.1$ million. The FY 1993 contribution to this escrow fund would be about $\$ 30,800$ using the same methodology that was used to calculate the FY 1993 closure cost.

The total cost of closure and post-closure monitoring is approximately $\$ 90,100$, (i.e., 60,300 plus $30,800)$.

\section{C.1.3.4 Bulky Waste Landfill}

The City paid a tipping fee of $\$ 67.12$ per ton to dispose of bulky wastes at a privately owned and operated landfill located in Chicopee, Massachusetts. This resulted in an annual FY 1993 cost to dispose of 807 tons of bulky wastes of $\$ 54,166 .{ }^{97}$

96 The closure costs may include expenses related to the prior use of the site as a landfill. Therefore, the closure costs related to the current use of Cell \#1 may be overstated.

97 DPW, "Solid Waste Management Plan," March 1994, page 24. 


\section{C.1.4 Waste-to-Energy Service Fee}

In FY 1993 Springfield Resource Recovery, Inc., the WTE operator, charged the City a monthly Service Fee of $\$ 216,543 .{ }^{98}$ This amounted to an annual Service Fee of $\$ 2,598,516$. The makeup of this Service Fee is shown in Table C.7.

The Service Fee is comprised of an O\&M Charge, Capital Charge and Passthrough costs. The Capital Charge covers the principal and interest payments on bonds and a return on the equity provided by the contractor to finance the development and construction of the facility. The Passthrough Costs include reimbursements for state and local taxes, water, lime, host community fees, environmental testing, and the disposal of unprocessible waste and ash. ${ }^{99}$

The contractor pays the City of tip fee of $\$ 18.73$ per dry ton for all of the ash disposed of at the Bondi's Island Landfill. For the portion of the ash generated from the City's MSW; the City pays the contractor this negotiated fee as part of the Passthrough Cost and is reimbursed this amount by the contractor for the use of the landfill. The Modified Service Fee shown in Table C.7 is the Annual Service Fee less the $\$ 474,970$ ash disposal portion of the City's Passthrough Cost.

The Modified Service Fee is shown in Table C.1 for the WTE Service Fee because: (1) the ash disposal passthrough cost is a negotiated price and not the cost of disposal of the ash incurred by the City; (2) the City is reimbursed this fee as part of the payments made by the contractor to the City for ash disposal; and (3) the actual costs of ash disposal are explicitly accounted for in this analysis as discussed in Section C.1.3.

The City must pay this annual O\&M and Capital fees for the first 58,040 tons of MSW it delivered to the facility (i.e., the City has a put-or-pay commitment of 58,040 tons). For each additional ton the City would have paid a maximum of $\$ 15.90$ per ton.

In FY 1993 the City's Solid Waste Division only delivered 44,707 tons of MSW to the WTE facility. An additional 970 tons was delivered to the WTE facility by other City departments such as the Parks, Public Housing, and Wastewater Treatment Departments. In this study this tonnage is treated like the tonnage delivered to the WTE facility by other communities. Furthermore, because the City did not meet its put-or-pay commitment and there was no additional cost at the WTE facility for this tonnage, none of the Service Fee payments made by the City are allocated to this tonnage.

\footnotetext{
${ }^{98}$ Springfield Resource Recovery, Inc., Letter to Mr. Tony Curto from Mr. Phil Pike, "FY93 Estimated Service Fee Calculation."

99 The contractor provides the City an estimate of the Service Fee at the beginning of each fiscal year. At the end of the year the contract calls for a reconciliation of the Service Fee. ("Springfield Resource Recovery Project, Restated Solid Waste Disposal Service Agreement," July 1, 1986, Section 6.) To date no such reconciliations have occurred. Therefore, for the purpose of this study the actual Service Fee paid is equal to the Estimated Service Fee.
} 


\section{C.1.5 Material Recovery Facility O\&M and Capital Costs}

The FY 1993 O\&M and Capital Cost of the MRF, as reported by the Commonwealth of Massachusetts, was $\$ 2,207,714$ (see Table C.8). ${ }^{100,101}$ The $\$ 2,207,714$ net cost incurred by the Commonwealth includes the costs paid to the operator of the MRF and the capital costs incurred to build the MRF. It excludes the $\$ 70,000 \mathrm{DEP}$ administration expense.

In FY 1993 the operator was paid $\$ 1,603,844$. This was equal to the sum of the $\$ 478,656$ Fixed Fee, $\$ 740,080$ Variable Fee, and $\$ 385,107$ revenue makeup. ${ }^{102}$ A total of $\$ 665,447$ was earned from the sale of recovered materials in FY 1993. This amount was kept by the contractor. ${ }^{103}$ Therefore, the gross O\&M cost at the MRF was the sum of $\$ 1,603,844$ and $\$ 665,447$, or $\$ 2,269,291$.

The DEP indicated that the cost to develop and construct the facility (building only) was $\$ 5.5$ million. The annual capital cost of $\$ 603,870$ was estimated using the procedure described in Appendix D. The cost of capital was assumed to be 7 percent and the useful life of the MRF was assumed to be 15 years.

The net O\&M and Capital cost for the MRF of $\$ 2,207,714$ is the sum of the total revenues received by the contractor and the capital costs paid by the Commonwealth less the revenues received from the sale of recovered materials, i.e., $\$ 2,269,291$ plus $\$ 603,870$ minus $\$ 665,447$.

The City delivered 7,070 tons of the 44,060 tons received at the MRF in FY 1993. Thus, about 16 percent of the total cost, or $\$ 354,256$ (i.e., 7,070 divided by 44,060 times $2,207,714$ ) was attributable to the City's tonnage. This is the value shown in Table C.1.

\section{C.1.6 HHW Collection Day Contractor Fees}

The City hired two contractors to assist them during there HHW collection day; Clean Harbors of Natick, Inc. and The Green Paint Company. The payments were not made out of the Solid Waste Division budget and, therefore, are not included in the Job Cost Data discussed in Section C.1.1. Clean Harbors was paid $\$ 26,900$ and The Green Paint Company was paid $\$ 1,246$ for a

100 DEP, "Monthly Revenue, Springfield Material Recycling Facility," written by Charles Leto, Department of Solid Waste Management, December 1992 and DEP, "Monthly Revenue, Springfield Material Recycling Facility," written by Greg Cooper, Department of Solid Waste Management, January 27, 1993.

101 The Commonwealth reported monthly results by calendar year. Data from both calendar year 1992 and 1993 were used to generate the FY93 results.

102 The contract assumed a weighted average revenue of $\$ 29.28$ per ton. In FY93 the average revenues actually received was less than $\$ 29.28$, thus, the Commonwealth had to pay the contractor a revenue makeup reflecting the Commonwealth's share (i.e., 65 percent) of the revenue shortfall.

${ }^{103}$ The Commonwealth and participating communities would receive 65 percent of this excess revenue, i.e., any revenues that result from average material prices exceeding $\$ 29.28$ per ton. Since the average revenues in calendar years 1992 and 1993 did not exceed this amount there were no excess revenues. 
total of $\$ 28,146 .^{104}$

\section{C.1.7 Bins, Cans \& Bags}

The bins used by residents to place their recyclables at the curb were purchased through a grant provided by the Commonwealth. Each resident was provided a single bin at a unit cost of $\$ 3.95$. Given that the City provides curbside collection to a reported 40,990 households, ${ }^{105}$ the estimated annual total purchase price of the bins is $\$ 161,910$. Assuming a cost of capital of 7 percent and a useful life of the bins of 10 years, and applying the procedure described in Appendix D the annual capital cost of the bins is about $\$ 23,100$.

The blue box recycling bins were also used for the office paper recycling program. approximately 15 bins were used per building. In addition, each building was supplied with two wheeled containers to sonsolidate the office paper and bring it to the pickup point for each building. Since office paper was collected in ten buildings, a total of 150 bins and 20 containers were used in this program. Each bin costs $\$ 3.95$ while each container costs $\$ 75$. Assuming a cost of capital of 7 percent, a useful life of the bins and containers of 10 and 5 years, respectively, the annual capital cost of the bins and containers is $\$ 450$.

In order to keep the analysis consistent the costs incurred by individuals to purchase garbage cans and plastic bags must also be estimated and included in the analysis. The costs of plastic bags and metal or plastic garbage cans is estimated by multiplying the cost of the bags or cans per tons of Garbage collected by the number tons collected. Plastic bags are not reusable and are, therefore, consumed when the garbage is picked up. On the other hand, garbage cans are capital goods similar to the recycling bins. Furthermore, many people use both plastic bags and garbage cans, i.e., the plastic bag is used as a liner for the garbage cans. To estimate the costs of plastic bags and garbage cans the following assumptions were used:

- individuals use either or both 30-gallon plastic bags or 30-gallon garbage cans;

- 65 percent of all residents use plastic bags, and 70 percent use garbage cans;

- a 30-gallon plastic bag and 30-gallon garbage can hold approximately 0.149 cubic yards or 0.011 tons of garbage; ${ }^{106}$

- the average cost of a 30 -gallon plastic bag is about $\$ 0.13 ;^{107}$

104 DEP, "May 1993 Household Hazardous Waste Collection Preliminary Report," undated.

105 DPW, "Solid Waste Management Plan," March 1994, p.12.

106 These values are based upon a conversion factor of 0.1337 cubic feet per gallon, and a bulk density of garbage in bags or cans of 150 pounds per cubic yard.

107 A survey of plastic bag costs at retail outlets and information obtained from First Brands of Danbury, Connecticut (makers of Glad Bags), indicated typical costs ranging from 8 to 18 cents per bag. The average of this range is 13 cents. 
- the average cost of a 30-gallon garbage can is $\$ 20$ and it has a useful life of 10 years; and

- the cost of capital is 7 percent.

Using the above assumptions, the costs of bags and cans (assumed used once a week) was estimated to be about $\$ 11.80$ per ton of Garbage collected and $\$ 5.00$ per ton of Garbage collected, respectively.

The estimated cost of bags and cans to residents for the 44,707 tons of Garbage collected by the City is:

$$
[(0.65)(11.80)+(0.70)(5.00)](44,707)=\$ 499,400 .
$$

The factor " 0.65 " reflects the assumption that 65 percent of all individuals use plastic bags. The factor " 0.70 " reflects the assumption that 70 percent of individuals use garbage cans.

Individuals that have their yard waste picked up by the City are required to place the yard waste in kraft paper bags or garbage cans. The costs of kraft paper bags and garbage cans is estimated by multiplying the cost of the bags or cans per ton of Yard Waste collected by the number tons collected. Kraft paper bags are not reusable and are, therefore, consumed when the yard waste is picked up. On the other hand, garbage cans are capital goods similar to the recycling bins. To estimate the costs of the kraft paper bags and garbage cans used for the collection of Yard Waste the following assumptions were used:

- $\quad$ individuals use either 30-gallon kraft paper bags or 30-gallon garbage cans;

- 80 percent of the Yard Waste is collected in kraft paper bags and 20 percent is collected in garbage cans;

- a 30-gallon kraft paper bag holds approximately 0.149 cubic yards or 0.022 tons of Yard Waste; ${ }^{108}$

- the average cost of a 30 -gallon kraft paper bag is about $\$ 0.365 ;^{109}$

Using the above assumptions, the costs of kraft paper bags was estimated to be about $\$ 16.60$ ] per ton of Yard Waste collected and the cost of garbage cans, assuming they are used once a week for 26 weeks a year, is $\$ 5.00$ per ton of Yard Waste.

108 These values are based upon a conversion factor of 0.1337 cubic feet per gallon, and a bulk density of yard waste in bags or cans of 300 pounds per cubic yard. Although the bulk density of yard waste can be greater than 300 pounds per cubic yard, it is assumed that the weight of each bag would, on average, not exceed 45 pounds, i.e., .022 tons.

109 The retail price of kraft paper bags in the Springfield area ranges between 0.33 and 0.40 cents per bag. (Discussion with Mr. Michael Triggs of the City's DPW, June 1994) The average of this range is 0.365 cents. 
The estimated cost of bags and cans to residents for the 6,814 tons of Yard Waste collected by the City is:

$$
[(0.80)(16.60)+(0.20)(5.00)](6,814)=\$ 97,300 .
$$

The total cost for the bins, bags, and cans is about $\$ 620,250$, (i.e., $23,100+450+499,400+$ 97,300).

\section{C.1.8 G\&A Expenses}

\section{C.1.8.1 DPW G\&A Expenses}

The FY 1993 Administration cost of the DPW is reported to be $\$ 633,210$, as shown in Table C.9. ${ }^{110}$ This cost reflects a $\$ 552,059$ direct labor charge and $\$ 81,151$ charge for leaves (i.e., vacations, holidays and sick leaves) for the DPW administrative staff. As discussed previously labor costs are increased by 35 percent to account for fringe benefits.

The G\&A costs also need to be increased to account for the capital assets used by the administrative personnel such as office space, office furniture, computers, fax machines, copier machines and other equipment. Since the City does not maintain a fixed asset account, it was impossible to determine the cost of these capital assets. Based on data from other cities that do maintain fixed asset accounts the capital costs of G\&A expenses are approximately 10 to 15 percent of the G\&A operating expenses. For this analysis the G\&A capital costs are assumed to be 10 percent of the G\&A operating expenses. Therefore, the total DPW G\&A expense, including fringe benefits and capital costs is estimated to be $\$ 909,100$ (i.e., 1.10 times the sum of $\$ 552,059$ times 1.35 , plus $\$ 81,151$ ).

The fraction of regular hours charge to the Solid Waste Division to the total regular hours charge to the DPW is used to determine the portion of this DPW G\&A expense to be allocated to the Solid Waste Division."11 The DPW G\&A cost allocated to the Solid Waste Division is, therefore, about 20.4 percent (i.e., 147,223 divided by the difference between 754,028 and 32,627 ) of $\$ 909,100$, or about $\$ 185,500$.

\section{C.1.8.2 City G\&A Expenses}

The methodology used to estimate the portion of the City G\&A costs attributable to the Solid Waste Division is: (1) determine the total City G\&A costs; (2) adjust these costs to account for fringe benefits and capital costs; (3) allocate a portion of the adjusted City G\&A costs to the DPW; and (4) allocate a portion of the City G\&A costs attributable to the DPW to the Solid Waste Division.

110 DPW, "Job Cost Summary Report," Computer Printout, August 12, 1993.

III The cost data presented in Table C.9 is not used to allocate the DPW G\&A expenses because the Job Cost Data does not clearly indicate whether these reported costs are operating expenses, capital outlays, debt service payments, or interest payment.

\section{C-11}


The DPW, including the Solid Waste Division, utilizes from time to time the services the City offices' and departments listed in Table C.10 along with their reported FY 1993 actual expenditures. Prior year expenditures are subtracted and encumbrances added to the total reported expenses. ${ }^{112}$ This cost is further adjusted to account for fringe benefits and capital cost by first adding 35 percent of the Personal Services costs (i.e., the estimate of fringe benefits) to the adjusted expenditures and then multiplying this sum by 1.10 to account for the capital costs. For example, the Adjusted City Auditor expense in Table C.10 is equal to:

$$
[(571,664-76,676+64,567)+(0.35)(466,021)](1.10)=794,900 \text {. }
$$

In a similar analysis conducted by the DPW in 1990 an estimated 6.5 percent of these City G\&A cost was "attributable to DPW support."113 Assuming this percentage is applicable for FY 1993, then $\$ 905,450$, (or 6.5 percent of $\$ 13,930,000$ ) of the City G\&A Costs is attributable to the DPW. As was done for the DPW G\&A expense about 20.4 percent, or about $\$ 184,800$ of this amount is attributable to the Solid Waste Division.

\section{C.1.8.3 Solid Waste Division G\&A Capital Cost}

The FY 1993 Administration expenses, including the estimate of fringe benefits, of the Solid Waste Division was $\$ 863,109$ (see Table C.3). The G\&A capital cost for the Solid Waste Division is assumed to be 10 percent of this amount, or about $\$ 86,310$.

\section{C.1.8.4 DEP G\&A Capital and O\&M Expenses}

The DEP estimated that its FY 1993 G\&A expenses related to the MRF were about $\$ 70,000^{114}$ (see Table C.8). The G\&A capital cost is estimated by multiplying this amount by 10 percent, resulting in a total G\&A Capital and O\&M cost of $\$ 77,000$ (i.e., 70,000 times 1.10). About 16 percent, or about $\$ 12,350$, of this amount is attributable to the City.

\section{C.1.9 White Good and Compost Revenues}

In FY 1993 the City earned $\$ 7,126$ from the sale of 509 tons of white good at $\$ 14.00$ per ton. In addition the City earned $\$ 3,784$ from the sale of 3,127 tons of compost at $\$ 1.21$ per ton.

\section{C.2 Program Incremental Costs}

The data and assumptions used to estimate the Program Incremental Costs for Springfield's

112 Encumbrances are assumed to be accrued FY93 expenses.

113 Department and Inter-Department Correspondence, "Indirect Overhead Impact on Cost of Providing Services," James Fitchet, Comptroller, DPW, February 8, 1990, p. 2.

114 For calendar year the DEP assumed a $\$ 100,000$ G\&A cost and in calendar year 1993 it assumed a $\$ 70,000$ G\&A cost. Greg Cooper of the DEP indicated that the 1993 number was based on a cursory assessment of the actual G\&A costs incurred. (Telephone call between Greg Cooper and Alan Cohen, May 1994). In this analysis the $\$ 70,000$ figure is used for FY93.

$$
\text { C-12 }
$$


resource recovery programs, i.e., the Waste-to-Energy, Curbside Recycling, Yard Waste Composting, Office Paper Recycling, and White Good Recycling Programs are presented below.

\section{C.2.2 Waste-to-Energy Program}

The FY 1993 estimated Program Incremental Cost for the Waste-to-Energy Program was about $\$ 323,000$, or $\$ 7$ per ton for the 45,677 tons of City waste combusted at the Facility. Table $4-4$ in Section 4.5 shows costs with and without the WTE Program and the incremental cost for various cost categories. ${ }^{115}$

The 45,677 tons consists of the 44,707 tons of MSW collected by the Solid Waste Division and delivered to the Facility plus 970 tons of waste brought to the Facility by other City Departments (e.g. Public Housing, Parks, and Wastewater Treatment). This additional 970 tons is included in the incremental cost analysis to account for the fact that the City would have had to landfill this waste if there were no waste-to-energy facility. On the other hand, this analysis does not consider the incremental costs (or savings) that are incurred by the other communities using the WTE Facility. ${ }^{116}$

A $\$ 61,400$ G\&A expense is assumed for the management of the WTE Program. This amount equals the cost of one full-time equivalent employee at a direct cost of $\$ 45,500$ and fringe benefits of 35 percent (i.e., $\$ 61,400$ equals 45,500 times 1.35 ). ${ }^{117}$

The principal cost of the WTE Program are the fees paid for the operation and maintenance of the Facility. The $\$ 4.59$ million inçremental cost of the WTE facility (see Table 4-4 in Section 4.5 ) is equal to the sum of the $\$ 2.8$ million O\&M fee (see Table B.4 of Appendix B) and the $\$ 1.8$ million capital fee (see Table B.8 of Appendix B). If there was no WTE Program all of these WTE Facility expenses would have been avoided. ${ }^{118}$

The estimated $\$ 1.89$ million savings in landfill costs is equal to an estimated landfill cost with the WTE Program of $\$ 646,000$ minus an estimated landfill cost without the WTE Program of $\$ 2.54$ million. The $\$ 646,000$ landfill cost, with the WTE program, was the total cost (i.e., contractor fees, capital cost, closure cost, and post closure monitoring cost) of disposing of the ash generated at the WTE Facility from the 45,677 tons of waste delivered to the Facility by the

115 Some costs that are the same with and without a program are not included in Tables 4-4 through 4-8 in Section 4.5.

116 Inclusion of the incremental costs to all the communities that use the WTE Facility is beyond the scope of this study. Since the City of Springfield has its own landfill, the incremental costs (or savings) estimated for Springfield should not be assumed to apply to other users of the WTE Facility.

117 The assumption that one-full time equivalent employee is devoted to the WTE Program is based on discussions with Mike Triggs of the Department of Public Works, Springfield, MA. The $\$ 45,500$ direct cost is based on City's Job Cost data.

118 When calculating costs without a program it is assumed that the program was never implemented. The costs of disbanding a program would be quite different because of existing contractual commitments and sunk costs. 
City. The costs of disposing of bulky waste, other City wastes (e.g., sludge), and ash from the other communities are not included in this cost. Except for the disposal of non-City ash, these later costs would be the same with or without the WTE Program. Because any profits or losses related to providing disposal service to other communities should not be included in the analysis of incremental cost, the costs and revenues of disposing of non-City ash at the Bondi's Island landfill are not included in this analysis. ${ }^{119}$

The $\$ 2.54$ million landfill cost, without the WTE program, is the total estimated cost (i.e., contractor fees, capital cost, closure cost, and post closure monitoring cost) to dispose of 45,677 tons at Springfield's Bondi's Island landfill. This cost assumes the fixed and variable fees paid the landfill contractor is FY 1993 would be the same if there were no WTE Facility. ${ }^{120}$

Specifically, the estimated annual landfill contractor fee is estimated to be $\$ 266,700$ plus $\$ 13.08 /$ ton times 45,677 tons, or $\$ 864,200$. The $\$ 266,700$ is the sum of the fixed Base Operating and Environmental Monitoring Fees, $\$ 13.08$ is the variable fee, and 45,677 is the number of tons disposed.

The estimated capital, closure, and post-closure monitoring costs are $\$ 1,065,400$ (i.e., 113,460 times 9.39), $\$ 401,700$ (i.e., 113,460 times 3.54 ), and $\$ 205,400$ (i.e., 113,460 times 1.81 ), respectively. The 113,460 is the estimated cubic yards consumed at the landfill to dispose of 45,677 tons of MSW. This was estimated using the following assumptions: MSW has a density, as disposed of in the landfill, of 2.16 cubic yards per ton; and cover material is assumed to consume another 15 percent of the capacity of the landfill. Thus, the total volume of landfill space consumed by disposing of 45,677 tons of MSW is equal to 45,677 times 2.16 times 1.15 , or 113,460 cubic yards. As discussed in Section C.1.3, the capital, closure, and post-closure monitoring costs are $\$ 9.39, \$ 3.54$, and $\$ 1.81$ per cubic yard, respectively.

The $\$ 2.54$ million landfill cost, without the WTE program, is equal to the sum of $\$ 864,200$, $\$ 1,065,400, \$ 401,700$ and $\$ 205,400$.

The \$2.44 million Revenue savings of the WTE Program shown in Table 4-4 are the electricity and steam revenues attributed to the City as shown in Table B.10. If there was no WTE Program these WTE Facility revenues would be lost.

There is assumed to be no incremental collection, materials recovery facility, composing operation, white goods preparation, and miscellaneous recycling costs (or savings) associated with the WTE Program. There are no incremental cost (or savings) because these other activities, except for collection are not affected by the WTE Program. There are no incremental collection costs (or savings) because the WTE Facility is located adjacent to the Bondi's Island landfill and there

119 The City received $\$ 18.73$ per dry-ton of non-City disposed of at the landfill. It costs the City about $\$ 34$ per dry-ton (including contractor variable fees, and capital, closure, and post-closure monitoring costs) to dispose of this ash.

120 To test this assumption CSI estimated the cost to operate and maintain the landfill without the WTE Facility. This analysis concluded that the current landfill fees would be sufficient to cover the O\&M costs of disposing of 45,677 tons of MSW at the landfill and a reasonable profit for the operator. 
would be no need to alter collection routes or change in haul distances if there were no WTE Facility.

\section{C.2.2 Curbside Recycling Program}

The FY 1993 estimated Program Incremental Cost for the Curbside Recycling Program was about $\$ 774,500$, or $\$ 111$ per ton for the 6,958 tons of City collected materials that were recycled. Table 4-5 in Section 4.5 shows costs with and without the Curbside Recycling Program and the incremental cost for various cost categories.

The 6,958 tons is equal to the 7,048 tons of recovered materials collected by the City less 90 tons of the associated residue generated at the MRF. This analysis does not consider the incremental costs (or savings) that would be incurred by the other communities using the MRF. ${ }^{121}$

A $\$ 61,400$ G\&A expense is assumed for the management of the MRF Program. This amount equals the cost of one full-time equivalent employee at a direct cost of $\$ 45,500$ and fringe benefits of 35 percent (i.e., $\$ 61,400$ equals 45,500 times 1.35 ). ${ }^{122}$

If there were no Curbside Recycling Program the City and Commonwealth could have saved about $\$ 231,500$ in direct collection costs (see Table B.3 of Appendix B), $\$ 64,200$ in recycling vehicle O\&M costs (see Table B.3 of Appendix B), $\$ 23,100$ in recycling bin costs, and $\$ 90,800$ in recycling vehicle capital costs (see Table B.8 of Appendix B). The sum of these costs is $\$ 409,600$.

On the other hand, if there were no Curbside Recycling Program an additional 7,048 tons per year (or about 2.8 tons per day per truck) of garbage would have had to have been collected by the City. CSI conducted an engineering assessment and computer analysis of collection costs in Springfield to estimate the incremental cost of collecting this additional tonnage. ${ }^{123}$ The results of this analysis indicated that no additional trucks, personnel, or overtime would be required to collect this additional tonnage. Furthermore, this material could be placed at the curb without any increase in the number of garbage bags or cans used by residents. Therefore, there would be no incremental cost of garbage collection if there were no Curbside Recycling Program.

The $\$ 409,600$ incremental collection cost of the Curbside Recycling Program is, therefore, equal to the difference of the $\$ 409,600$ cost of collecting recyclables and $\$ 0$ savings of collecting garbage.

121 Inclusion of the incremental costs for the 90 plus communities that use the MRF is beyond the scope of this study. Since the City of Springfield has its own landfill, the incremental costs (or savings) estimated for Springfield should not be assumed to apply to other users of the MRF.

122 The assumption that one-full time equivalent employee is devoted to the Curbside Recycling Program is based on discussions with Mike Triggs of the Department of Public Works, Springfield, MA. The City has one full time person devoted to monitor, promote, and manage their recycling programs. If there were no Curbside Recycling Program this position would most likely not exist. The $\$ 45,500$ direct cost is based on City's Job Cost data.

123 CSI, "MSW Management Assessment Model," Collection Submodel, 1994.

$$
\text { C-15 }
$$


Since Springfield's Curbside Recycling Program was implemented in conjunction with the development of the MRF, it is assumed, for the purposed of this analysis, that if Springfield did not implement a Curbside Recycling Program, then the MRF would not have been built. The $\$ 461,000$ Material Recovery Facility incremental cost shown in Table 4-5 is Springfield share of the MRF O\&M and Capital costs, i.e., $\$ 287,300$ O\&M cost (see Table B.4 of Appendix B) and 173,700 capital cost (see Table B.8 of Appendix B).

Because the 7,048 tons of recovered materials would have been collected as garbage, it is assumed that this material would have been delivered to the WTE Facility. Because the City paid for 58,040 tons of MSW and only delivered 45,677 tons, there is no incremental cost of processing this additional tonnage at the WTE Facility. ${ }^{124}$

The estimated $\$ 50,960$ incremental savings in landfill costs is equal to the avoided cost of disposing an estimated additional 1,487 dry-tons of ash. ${ }^{125}$ Specifically, the estimated incremental landfill contractor fee is equal $\$ 13.08 /$ ton times 1,487 tons, or $\$ 19,450$. The $\$ 13.08$ per dry-ton fee is the variable fee charge by the contractor for ash disposal. The estimated capital, closure, and post-closure monitoring costs are $\$ 20,080$ (i.e., 2,138 times 9.39), $\$ 7,570$ (i.e., 2,138 times 3.54 ), and $\$ 3,870$ (i.e., 2,138 times 1.81 ), respectively. The 2,138 is the estimated cubic yards consumed at the landfill to dispose of 1,487 dry-tons of ash. The cubic yardage of landfill space consumed was estimated using the following assumptions: ash with a 20 percent moisture content has a density, as disposed of in the landfill, of 1.0 cubic yards per ton; and cover material is assumed to consume another 15 percent of the capacity of the landfill. Thus, the total volume of landfill space consumed by disposing of 1,487 dry-tons of ash is equal to 1,487 divided by .8 times 1.0 times 1.15, or 2,138 cubic yards. As discussed in Section C.1.3, the capital, closure, and post-closure monitoring costs are $\$ 9.39, \$ 3.54$, and $\$ 1.81$ per cubic yard, respectively.

The $\$ 50,960$ landfill cost, without the Curbside Recycling program, is equal to the sum of $\$ 19,450, \$ 20,070, \$ 7,570$ and $\$ 3,870$.

The \$106,580 Revenue savings of the Curbside Recycling Program shown in Table 4-5 is equal to the $\$ 106,780$ material recovery facility revenue attributed to the City as shown in Table B.10 less $\$ 196$ in revenues attributed to the Office Paper Recycling Program. If there was no Curbside Recycling Program these revenues would be lost.

There is assumed to be no incremental composting operation, white goods preparation, and miscellaneous recycling costs (or savings) associated with the Curbside Recycling Program. There are no incremental cost (or savings) because these other activities are not affected by the Curbside Recycling Program.

124 In Section 4.5 the impact of this assumption of the Curbside Recycling Program Incremental Costs is discussed.

125 The composition of the recovered materials was taken into account to estimate the ash generated from combusting 7,048 tons of these recovered materials. 


\section{C.2.3 Yard Waste Composting Program}

The FY 1993 estimated Program Incremental Cost for the Yard Waste Composting Program was about $\$ 274,000$, or $\$ 36$ per ton for the 7,515 tons of City yard waste that was composted. Table 4-6 in Section 4.5 shows costs with and without the Yard Waste Composting Program and the incremental cost for various cost categories.

The 7,515 tons is equal to the sum of 6,814 tons of yard waste collected at the curb by the City, 337 tons of yard waste collected from street sweeping operations, and 364 tons of yard waste that was self-hauled by City residents. This analysis does not consider the incremental costs (or savings) that are incurred by the City of Agawam. ${ }^{126}$ If there were no yard waste composting operation the City would have to still manage the street sweepings and self-hauled yard waste, therefore, these wastes are included in the incremental analysis.

If there were no Yard Waste Composting Program the City and City residents could have saved about $\$ 72,570$ in overtime collection costs (see Table B.3 of Appendix B), $\$ 16,190$ in garbage vehicle O\&M costs (see Table B.3 of Appendix B), $\$ 58,330$ in bag and can costs, and $\$ 8,090$ yard waste drop-off operation costs (see Table B.3 of Appendix B). ${ }^{127}$ The sum of these incremental costs is about $\$ 155,170$.

The $\$ 58,330$ cost of bags and cans was estimated by assuming that 30 -gallon plastic bags at a cost of $\$ 5.90 /$ ton of yard waste disposed would be substituted for 30-gallon kraft-paper bags at a cost of $\$ 16.60 /$ ton; on average 45 pound of yard waste is placed in a 30 -gallon bag; ${ }^{128}$ and households that use cans will continue to use cans.

On the other hand, if there were no Yard Waste Composting Program, an additional 7,515 tons per year of garbage would have had to have been collected by the City during the growing seasons, i.e., about 26 weeks. CSI conducted an engineering assessment and computer analysis of collection costs in Springfield to estimate the incremental cost of collecting this additional tonnage. ${ }^{29}$ The analysis took into account the fact in FY 1993 the City collected garbage 4 times a week and yard waste twice a week. If there were no Yard Waste Composting Program garbage collection could be done 5 times a week. The results of this analysis indicated that no additional trucks, personnel, or overtime would be required to collect this additional tonnage. Therefore, there would be no incremental cost of garbage collection if there were no Curbside Recycling Program.

126 Inclusion of the incremental costs for Agawam is beyond the scope of this study.

127 The cost incurred by residents of Springfield to self-haul yard waste to Bondi's Island is unknown and not included in this analysis. Therefore, the incremental collection cost of the Yard Waste Composting Program are understated by this self-haul cost.

128 See Section C.1.7 for the method used to derive the cost of using plastic and kraft paper bags. Because the density of yard waste placed in plastic bags is assumed to be twice that of garbage, the cost of using plastic bags for yard waste is half the cost, (i.e., $\$ 11.80$ divided by 2 , or $\$ 5.90 /$ ton)

129 CSI, "MSW Management Assessment Model," Collection Submodel, 1994. 
The $\$ 155,170$ incremental collection cost of the Yard Waste Composting Program is, therefore, equal to the difference of the $\$ 155,170$ cost of collecting yard waste and $\$ 0$ savings of collecting garbage.

If there were no Yard Waste Composting Program the City and Commonwealth would avoid the $\$ 147,560$ cost of the composting operation. This cost is equal to the sum of $\$ 36,570$ O\&M cost of the compost operation (see Table B.4 of Appendix B); $\$ 29,630$ cost of the compost equipment O\&M (see Table B.4 of Appendix B); the $\$ 64,120$ compost equipment capital cost (see Table B.8 of Appendix B); and $\$ 17,240$ attributed to the composting of street sweeping and self-hauled yard waste. ${ }^{130}$

Because the 7,515 tons of recovered materials would have been collected as garbage, it is assumed that this material would have been delivered to the WTE Facility. Because the City paid for 58,040 tons of MSW and only delivered 45,677 tons, there is no incremental cost of processing this additional tonnage at the WTE Facility. ${ }^{131}$

The estimated $\$ 25,100$ incremental savings in landfill costs is equal to the avoided cost of disposing an estimated additional 732 dry-tons of ash. Specifically, the estimated incremental landfill contractor fee is equal $\$ 13.08$ /ton times 732 tons, or $\$ 9,580$. The $\$ 13.08$ per dry-ton fee is the variable fee charge by the contractor for ash disposal. The estimated capital, closure, and post-closure monitoring costs are $\$ 9,890$ (i.e., 1,053 times 9.39 ), $\$ 3,730$ (i.e., 1,053 times 3.54 ), and $\$ 1,900$ (i.e.; 1,053 times 1.81 ), respectively. The 1,053 is the estimated cubic yards consumed at the landfill to dispose of 732 dry-tons of ash. The cubic yardage of landfill space consumed was estimated using the following assumptions: ash with a 20 percent moisture content has a density, as disposed of in the landfill, of 1.0 cubic yards per ton; and cover material is assumed to consume another 15 percent of the capacity of the landfill. Thus, the total volume of landfill space consumed by disposing of 732 dry-tons of ash is equal to 732 divided by .8 times 1.0 times 1.15, or 1,053 cubic yards. As discussed in Section C.1.3, the capital, closure, and postclosure monitoring costs are $\$ 9.39, \$ 3.54$, and $\$ 1.81$ per cubic yard, respectively.

The $\$ 25,100$ landfill cost, without the Curbside Recycling program, is about equal to the sum of $\$ 9,580, \$ 9,890, \$ 3,730$ and $\$ 1,900$.

The $\$ 3,500$ revenue savings of the Yard Waste Composting Program shown in Table 4-5 is the revenues attributed to the City from the sale of compost as shown in Table B.10. ${ }^{132}$ If there was

130 About $\$ 14,930$ of the cost of the compost operation is not included in the incremental cost analysis. This is the proportion of the compost operation O\&M and capital costs allocated to the processing of yard waste from Agawam. The City of Agawam paid Springfield $\$ 14,880$ to process 607 tons of yard waste, therefore, there is virtually no net effect on the estimated Yard Waste Processing incremental cost of excluding the Agawam cost and revenues.

131 In Section 4.5 the impact of this assumption of the Yard Waste Composting Program Incremental Costs is discussed.

132 This exclude about $\$ 280$ of revenues that are attributed to the City of Agawam's yard waste. Exclusion of this revenue has little or no impact on the estimated incremental cost of the Yard Waste Composting Program. 
no Curbside Recycling Program these revenues would be lost.

There is assumed to be no incremental G\&A, Material Recovery Facility, white goods preparation, and miscellaneous recycling costs (or savings) associated with the Yard Waste Composting Program. There are no incremental cost (or savings) because these other activities are not affected by the Yard Waste Composting Program.

\section{C.2.4 Office Paper Recycling Program}

The FY 1993 estimated Program Incremental Cost for the Office Paper Recycling Program was about $\$ 1,500$, or $\$ 68$ per ton for the 22 tons of office paper collected by the City. Table 4-7 in Section 4.5 shows costs with and without the Office Paper Recycling and the incremental cost for various cost categories.

The $\$ 910$ incremental collection cost is equal to the sum of a $\$ 460$ vehicle O\&M cost and $\$ 450$ bin and container capital cost. The vehicle $O \& M$ cost is equal to 5 percent of the $\$ 9,125$ O\&M cost for truck number 308 (see Table C.4). This vehicle is used 95 percent of the time for litter collection and 5 percent of the time for office paper collection. The $\$ 450$ bin and container capital cost was estimated using the procedure described in Appendix $\mathrm{D}$ and the following data and assumptions: 15 recycling bins were used per building; 2 containers were used per building; 10 City office building were served in FY 1993; each bin cost $\$ 3.95$ and has a useful life of 10 years; and each container cost $\$ 75$ and has a 5 year useful life.

The $\$ 874$ incremental cost reflects the additional O\&M cost that was born by the Commonwealth to process the 22 tons of office paper at the MRF. If there was no Office Paper Recycling Program the 22 tons of recovered materials would have been collected as garbage and delivered to the WTE Facility. Because the City paid for 58,040 tons of MSW and only delivered 45,677 tons, there is no incremental cost of processing this additional tonnage at the WTE Facility. ${ }^{133}$

The estimated $\$ 89$ incremental savings in landfill costs is equal to the avoided cost of disposing an estimated additional 2.59 dry-tons of ash. Specifically, the estimated incremental landfill contractor fee is equal $\$ 13.08 /$ ton times 2.59 tons, or $\$ 34$. The $\$ 13.08$ per dry-ton fee is the variable fee charge by the contractor for ash disposal. The estimated capital, closure, and postclosure monitoring costs are $\$ 35$ (i.e., 3.72 times 9.39), $\$ 13$ (i.e., 3.72 times 3.54), and $\$ 7$ (i.e., 3.72 times 1.81 ), respectively. The 3.72 is the estimated cubic yards consumed at the landfill to dispose of 2.59 dry-tons of ash. The cubic yardage of landfill space consumed was estimated using the following assumptions: ash with a 20 percent moisture content has a density, as disposed of in the landfill, of 1.0 cubic yards per ton; and cover material is assumed to consume another 15 percent of the capacity of the landfill. Thus, the total volume of landfill space consumed by disposing of 2.59 dry-tons of ash is equal to 2.59 divided by .8 times 1.0 times 1.15 , or 3.72 cubic yards. As discussed in Section C.1.3, the capital, closure, and post-closure monitoring costs are $\$ 9.39, \$ 3.54$, and $\$ 1.81$ per cubic yard, respectively.

The $\$ 89$ landfill cost, without the Office Paper Recycling Program, is equal to the sum of $\$ 34$,

133 In Section 4.5 the impact of this assumption of the Office Paper Recycling Program Incremental Costs is discussed. 
$\$ 35, \$ 13$ and $\$ 7$.

The $\$ 196$ revenue savings of the Office Paper Recycling Program shown in Table 4-5 is the revenues attributed to the City from the sale of paper at the MRF. ${ }^{134}$ If there was no Office Paper Recycling Program these revenues would be lost.

There is assumed to be no incremental G\&A, composting operation, white goods preparation, and miscellaneous recycling costs (or savings) associated with the Office Paper Recycling Program. There are no incremental costs (or savings) because these other activities are not affected by the Office Paper Recycling Program.

\section{C.2.5 White Goods Recycling Program}

The FY 1993 estimated Program Incremental Savings for the White Goods Recycling Program was about $\$ 41,300$, or $\$ 81$ per ton for the 509 tons of white goods collected by the City. ${ }^{135}$ Table 4-8 in Section 4.5 shows costs with and without the White Good Recycling Program and the incremental cost for various cost categories.

For purposed of this analysis it is assumed that without the White Goods Recycling Program the City would bring the white goods to the Chicopee landfill for processing (e.g., removal of CFCs), and disposal. For this assumption there would be no incremental collection cost (or savings) or incremental white good preparation cost (or savings). Because the Chicopee landfill is located in the neighboring City it is assumed that the incremental haul cost to the landfill is minimal.

The most significant savings of the White Goods Recycling Program is the savings of the landfill tip fee of $\$ 67.12$ per ton. For the 509 tons of white goods diverted from the landfill this amounted to an incremental landfill savings of $\$ 34,160$ (i.e., 67.12 times 509). In addition, $\$ 7,126$ in revenues were earned from the sale of the white goods (see Table B.10).

134 This office paper is mixed with the other paper delivered to the MRF and, therefore, was sold as mixed and/or newspaper and not high grade office paper.

135 Of the 509 tons collected about 433 tons of metals and plastics (i.e., 85 percent of 509) are recovered for recycling. The average incremental savings for the materials recovered was $\$ 95$ per ton (i.e., $\$ 41,300$ divided by 433$)$. 
Table C.1: Derivation of Total Net Costs for Springfield's IMSWM System (FY 1993)

\begin{tabular}{lrc}
\hline Activity & $\begin{array}{r}\text { Total } \\
\text { Net Cost }\end{array}$ & References \\
& & \\
\hline Solid Waste Division Job Cost Data & $\$ 2,823,338$ & Section C.1.1 \\
Vehicle and Equipment O\&M and Capital Expenses & 776,054 & Section C.1.2 \\
Bondi's Island Cell \#1 Landfill Contractor Fees & 783,558 & Section C.1.3 \\
Bondi's Island Cell \#1 Landfill Capital Cost & 159,807 & Section C.1.3 \\
Bondi's Island Cell \#1 Landfill Closure Costs & 91,081 & Section C.1.3 \\
Bulky Waste Landfill Tip Fees & 54,166 & Section C.1.3 \\
Waste-to-Energy Facility Service Fee & $2,123,546$ & Section C.1.4 \\
MRF Capital \& Net O\&M Costs & 354,256 & Section C.1.5 \\
HHW Collection Day Contractor Fees & 28,146 & Section C.1.6 \\
Bins, Cans, \& Bags & 620,250 & Section C.1.7 \\
DPW G\&A Capital and O\&M Expenses & 185,540 & Section C.1.8 \\
City G\&A Capital and O\&M Expenses & 184,800 & Section C.1.8 \\
Solid Waste Division G\&A Capital Cost & 86,310 & Section C.1.8 \\
DEP G\&A Capital and O\&M Expenses & 12,350 & Section C.1.8 \\
White Good Revenues & $17,126)$ & Section C.1.9 \\
Compost Revenues & $13,784)$ & Section C.1.9 \\
& & \\
Totals & $\$ 8,272,000$ & \\
\hline
\end{tabular}


Table C.2: Solid Waste Division Operating Expenses (FY 1993)

\begin{tabular}{|c|c|c|c|c|}
\hline Account & Labor & $\begin{array}{r}\text { Rented } \\
\text { Equipment }\end{array}$ & $\begin{array}{r}\text { Materials/ } \\
\text { Services }\end{array}$ & Total \\
\hline \multicolumn{5}{|l|}{ GENERAL \& ADMINISTRATIVE } \\
\hline Administration & 291,673 & & 180,166 & 471,839 \\
\hline Leave & 226,717 & & 73,325 & 300,042 \\
\hline Subtotal & 518,390 & 0 & 253,491 & 771,881 \\
\hline \multicolumn{5}{|l|}{ CLEANING \& OTHER GENERAL OPERATIONS } \\
\hline Street Cleaning & 106,959 & & 6,316 & 113,275 \\
\hline General Patching \& Repairs & 4,968 & & & 4,968 \\
\hline Misc. Fence Repair & 563 & & & 563 \\
\hline Lot Cleaning & 1,124 & & 16,602 & 17,726 \\
\hline Litter Contol & 55,801 & & 996 & 56,797 \\
\hline Cleaning Catch Basins \& Cross Walks & 384 & & 672 & 1,056 \\
\hline Cleaning Conservation Areas & 200 & & 874 & 1,074 \\
\hline Parking Lot Sweoping & 109 & & & 109 \\
\hline Subtotal & 170,107 & 0 & 25,460 & 195,567 \\
\hline MAINTENANCE OF GARAGE, GROUNDS, \& ROADS & 465 & & & 465 \\
\hline DPW VEHICLE REPAIR \& MAINTENANCE & 8,930 & & & 8,930 \\
\hline \multicolumn{5}{|l|}{ GARBAGE COLLECTION } \\
\hline Collection of Household Garbage & 695,248 & & $(24,146)$ & 671,102 \\
\hline Collection of Household Garbage (Special Overtime) & 71.139 & & & 71,139 \\
\hline Cash Bonus System & 44,012 & & & 44,012 \\
\hline Tonnage Incentive & 10,490 & & & 10,490 \\
\hline Driver's Incentive & 19,043 & & & 19,043 \\
\hline Subtotal & 839,932 & 0 & $(24.146)$ & $\overline{815,786}$ \\
\hline
\end{tabular}


Table C.2: Solid Waste Division Operating Expenses (FY 1993)

\begin{tabular}{|c|c|c|c|c|}
\hline Account & Labor & $\begin{array}{r}\text { Rented } \\
\text { Equipment }\end{array}$ & $\begin{array}{r}\text { Materials/ } \\
\text { Services }\end{array}$ & Total \\
\hline \multicolumn{5}{|l|}{ YARD WASTE CQLLECTION } \\
\hline Collection of Yard Waste & 6,439 & & & 6,439 \\
\hline Loadpacker Leaf Compost Pickup & 66,069 & & & 66,069 \\
\hline Subtotal & 72,508 & 0 & 0 & 72,508 \\
\hline \multicolumn{5}{|l|}{ WHITE GOODS (METALIC) BULK COLLECTIONS } \\
\hline Collection of White Goods \& Other Bulky Metals & 40,479 & & 2,886 & 43,365 \\
\hline Driver's Incentive & 1,609 & & & 1,609 \\
\hline Cash Bonus & 3,033 & & & 3,033 \\
\hline Stockpile Cleanup & 2,838 & & & 2,838 \\
\hline Subtotal & 47,958 & 0 & 2,886 & 50,844 \\
\hline \multicolumn{5}{|l|}{ NON-METALLC BULK COLLECTION } \\
\hline Collection of Bulky Wastes & 46,521 & & 44,009 & 90,530 \\
\hline Driver Incentive & 1,639 & & & 1,639 \\
\hline Cash Bonus & 3,617 & & & 3,617 \\
\hline Subtotal & 51,777 & 0 & 44,009 & 95,786 \\
\hline \multicolumn{5}{|l|}{ BECYCLUNC COLLECTION \& RELATED ACTIVITIES } \\
\hline General & $2,757^{\circ}$ & & 222 & 2,979 \\
\hline Eduction & 0 & & 150 & 150 \\
\hline Collection of Recyclables & 150,182 & & 6,137 & 156,319 \\
\hline Driver's Incentive & 10,709 & & & 10,709 \\
\hline Cash Bonus & 11,931 & & & 11.931 \\
\hline Subtotal & 175,579 & 0 & 6,509 & 182,088 \\
\hline
\end{tabular}


Table C.2: Solid Waste Division Operating Expenses (FY 1993)

\begin{tabular}{|c|c|c|c|c|}
\hline Account & Labor & $\begin{array}{r}\text { Rented } \\
\text { Equipment }\end{array}$ & $\begin{array}{r}\text { Materials/ } \\
\text { Services }\end{array}$ & Total \\
\hline \multicolumn{5}{|l|}{ YARD WASTE COMPOSTING } \\
\hline General & 474 & & & 474 \\
\hline Preliminary Site Work & 0 & & 30 & 30 \\
\hline Drainage Work & 369 & & & 369 \\
\hline Gravel Fill & 0 & & 1,625 & 1.625 \\
\hline Windrow Placement & 3,044 & & .0 & 3,044 \\
\hline Supervision & 535 & & & 535 \\
\hline Drop Off Site Supervision & 5,475 & & & 5,475 \\
\hline Placement & 1,076 & & & 1,076 \\
\hline SCARAG Training & 108 & & & 108 \\
\hline SCARAB Operations & 4,721 & & & 4,721 \\
\hline Removal of Drop Off Site Leaves & 1,106 & & 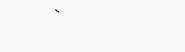 & 1,106 \\
\hline Windrow Maintenance & 12,901 & & . & 12,901 \\
\hline Water Truck Opertions & 821 & & & 821 \\
\hline Site Maintenance & 3,258 & & & 3,258 \\
\hline Curing Operations & 416 & & & 416 \\
\hline Site Restoration & 477 & & 800 & 1,277 \\
\hline Transportation of Finished Compost & 1,000 & 2,980 & & 3,980 \\
\hline Subtotal & 35,781 & 2,980 & 2,455 & 41,216 \\
\hline \multicolumn{5}{|l|}{ WASTE-TO-ENERGY FACILITY } \\
\hline Energy Recovery Facility & 0 & & 19,050 & 19,050 \\
\hline Estimated Service Fee Payments & 0 & & $2,595,166$ & $2,595,166$ \\
\hline Subtotal & 0 & 0 & $2,614,216$ & $2,614,216$ \\
\hline BONDUISLAND SANITARY LANDFILL & 0 & & 13,042 & 13,042 \\
\hline
\end{tabular}


Table C.2: Solid Waste Division Operating Expenses (FY 1993)

\begin{tabular}{|c|c|c|c|c|}
\hline Account & Labor & $\begin{array}{r}\text { Rented } \\
\text { Equipment }\end{array}$ & $\begin{array}{r}\text { Materials/ } \\
\text { Services }\end{array}$ & Total \\
\hline LANDEILL OPERATIONS & & & & \\
\hline Sanitary Landfill Operation & 654 & & 55,477 & 56,131 \\
\hline Methane Gas Collection & 0 & & 4,436 & 4,436 \\
\hline Landfill Expansion & 0 & & 38,832 & 38,832 \\
\hline Suspect Water Break (1/26/93) & 224 & & 47 & 271 \\
\hline New Monitoring Wells & 0 & & 313 & 313 \\
\hline General Maintenance (West Springfield) & 0 & & 514 & 514 \\
\hline Storm Water Drain Project (West Springfield) & 11,441 & 5,725 & 6,040 & 23,206 \\
\hline Subtotal & 12,319 & 5,725 & 105,659 & 123,703 \\
\hline \multicolumn{5}{|l|}{ SALE OF MATEAIALS \& SERVICES } \\
\hline Taste of Springfield (6/17/92 to 6/22/92) & 2,668 & & & 2,668 \\
\hline Glendi Festival & 128 & & & 128 \\
\hline Pancake Breakfast (5/15 \& 5/16/93) & 1,235 & & & 1,235 \\
\hline Eastern Ave \& Olive Street & 809 & 1,960 & 6,271 & 9,040 \\
\hline Worthington Fort Clean Up & 395 & & 161 & 556 \\
\hline Taste of Springfield $6 / 16 / 93$ & 7,474 & & & 7,474 \\
\hline Subtotal & 12,709 & 1.960 & 6,432 & 21,101 \\
\hline TOTAL COSTS FY93 & $1,946,455$ & 10,665 & $3,050,013$ & $5,007,133$ \\
\hline
\end{tabular}

Source: DPW, "Job Cost Summary Report," Computer Pintout, August 12, 1983. 
Table C.3: Adjusted Solid Waste Division Operating Expenses (FY 1993)

\begin{tabular}{|c|c|c|c|c|c|}
\hline Account & Labor & $\begin{array}{r}\text { Fringe } \\
\text { Benefits }\end{array}$ & $\begin{array}{r}\text { Rented } \\
\text { Equipment }\end{array}$ & $\begin{array}{r}\text { Materials/ } \\
\text { Services }\end{array}$ & Totall \\
\hline \multicolumn{6}{|l|}{ GENERAL \& ADMINISTRATIVE } \\
\hline Administration & 291,673 & 100,065 & & 171,329 & 563,067 \\
\hline Leave & 226,717 & & & 73,325 & 300,042 \\
\hline Subtotal & 518,390 & 100,065 & 0 & 244,654 & 863,109 \\
\hline \multicolumn{6}{|l|}{ CLEANING \& OTHER GENEBAL OPERATIONS } \\
\hline Street Cleaning & 106,959 & 35,874 & . & 6,316 & 149,148 \\
\hline General Patching \& Repairs & 4,968 & 1.739 & & & 6,706 \\
\hline Misc. Fence Repair & 563 & 197 & & & 760 \\
\hline Lot Cleaning & 1,124 & 393 & & 16,602 & 18,119 \\
\hline Litter Contol & 55,801 & 19,463 & & 996 & 76,260 \\
\hline Cleaning Catch Basins \& Cross Walks & 384 & 134 & & 672 & 1,190 \\
\hline Cleaning Conservation Areas & 200 & 70 & & 874 & 1,144 \\
\hline Parking Lot Sweeping & 109 & 38 & & & 147 \\
\hline Subtotal & 170,107 & 57,908 & 0 & 25,460 & 253,476 \\
\hline MAINT. OF GARAGE, GROUNDS, \& ROADS & 465 & 132 & & & 597 \\
\hline DPW VEHICLE REPAIR \& MAINTENANCE & 0 & & $\cdot$ & & 0 \\
\hline \multicolumn{6}{|l|}{ GARBAGE COULECTION } \\
\hline Collection of Household Garbage & 695,248 & 240,552 & & 0 & 935,800 \\
\hline Collection of Household Garbage (Special O & 71,139 & 165 & & & 71,304 \\
\hline Cash Bonus System & 44,012 & & & & 44,012 \\
\hline Tonnage Incentive & 10,490 & & & & 10,490 \\
\hline Driver's Incentive & 19,043 & & & & 19,043 \\
\hline Subtotal & 839,932 & 240,717 & 0 & 0 & $1,080,649$ \\
\hline
\end{tabular}


Table C.3: Adjusted Solid Waste Division Operating Expenses (FY 1993)

\begin{tabular}{|c|c|c|c|c|c|}
\hline Account & Labor & $\begin{array}{r}\text { Fringe } \\
\text { Benofits }\end{array}$ & $\begin{array}{r}\text { Rented } \\
\text { Equipment }\end{array}$ & $\begin{array}{r}\text { Materials/ } \\
\text { Services }\end{array}$ & Totall \\
\hline \multicolumn{6}{|l|}{ YARD WASTE COLLECTION } \\
\hline Collection of Yard Waste & 6,439 & & & & 6,439 \\
\hline Loadpacker Leaf Compost Pickup & 66,069 & 60 & & & 66,129 \\
\hline Subtotal & 72,508 & 60 & 0 & 0 & 72,568 \\
\hline \multicolumn{6}{|l|}{ WHIIE GOODS IMETALICI BULK COLLECTIONS } \\
\hline Collection of White Goods \& Other Bulky M & 40,479 & 14,072 & & 2,886 & 57,437 \\
\hline Driver's Incentive & 1,609 & & & & 1,609 \\
\hline Cash Bonus & 3,033 & & & & 3,033 \\
\hline Stockpile Cleanup & 2,838 & 993 & & & 3,831 \\
\hline Subtotal & 47,958 & 15,065 & $\overline{0}$ & 2,886 & 65,910 \\
\hline \multicolumn{6}{|l|}{ NON-METALC BULK COLLECTION } \\
\hline Collection of Bulky Wastes & 46,521 & 16,156 & & 0 & 62,676 \\
\hline Driver Incentive & 1,639 & & & & 1,639 \\
\hline Cash Bonus & 3,617 & & & & 3,617 \\
\hline Subtotal & 51.777 & 16,156 & $\overline{0}$ & 0 & 67,932 \\
\hline \multicolumn{6}{|c|}{ BECYCLING COLLLECTION \& RELLTED ACTIVITIES } \\
\hline General & 2,757 & 955 & & 222 & 3,933 \\
\hline Eduction & 0 & & & 150 & 150 \\
\hline Collection of Recyclables & 150,182 & 52,552 & & 6,137 & 208,871 \\
\hline Driver's Incentive & 10,709 & & & & 10,709 \\
\hline Cash Bonus & 11,931 & & & & 11,931 \\
\hline Subtotal & 175,579 & 53,507 & 0 & 6,509 & 235,594 \\
\hline
\end{tabular}


Table C.3: Adjusted Solid Waste Division Operating Expenses (FY 1993)

\begin{tabular}{|c|c|c|c|c|c|}
\hline Account & Labor & $\begin{array}{r}\text { Fringo } \\
\text { Benefits }\end{array}$ & $\begin{array}{r}\text { Rented } \\
\text { Equipment }\end{array}$ & $\begin{array}{r}\text { Materials/ } \\
\text { Services }\end{array}$ & Total \\
\hline \multicolumn{6}{|l|}{ YARD WASTE COMPOSTING } \\
\hline General & 474 & 166 & & & 640 \\
\hline Preliminary Site Work & 0 & & & 30 & 30 \\
\hline Drainage Work & 369 & 118 & , & & 487 \\
\hline Gravel Fill & 0 & & & 1,625 & 1,625 \\
\hline Windrow Placement & 3,044 & 277 & & 0 & 3,321 \\
\hline Supervision & 535 & 187 & & & 722 \\
\hline Drop Off Site Supervision & 5,475 & 1,117 & & & 6,592 \\
\hline Placement & 1,076 & 377 & & & 1,453 \\
\hline SCARAG Training & 108 & 38 & & & 146 \\
\hline SCARAB Operations & 4,721 & 1,353 & & & 6,074 \\
\hline Removal of Drop Off Site Leaves & 1,106 & 387 & & & 1,493 \\
\hline Windrow Maintenance & 12,901 & 4,515 & & & 17,416 \\
\hline Water Truck Opertions & 821 & 114 & & & 935 \\
\hline Site Maintenance & 3,258 & 1,140 & & & 4,398 \\
\hline Curing Operations & 416 & 146 & & & 562 \\
\hline Site Restoration & 477 & 167 & & 800 & 1,444 \\
\hline Transportation of Finished Compost & 1,000 & 350 & 2,980 & & 4,330 \\
\hline Subtotal & 35,781 & 10,452 & 2,980 & 2,455 & 51,668 \\
\hline \multicolumn{6}{|l|}{ WASTE-TO-ENEBGY FACILITY } \\
\hline Energy Recovery Facility Consulting Fees & 0 & & & 27,792 & 27.792 \\
\hline Estimated Service Feo Payments & 0 & & & 0 & 0 \\
\hline Subtotal & . 0 & 0 & 0 & 27.792 & 27,792 \\
\hline BONDUSLAND SANITARYLANDFILL. & 0 & 0 & & 4,300 & 4,300 \\
\hline
\end{tabular}


Table C.3: Adjusted Solid Waste Division Operating Expenses (FY 1993)

\begin{tabular}{|c|c|c|c|c|c|}
\hline Account & Labor & $\begin{array}{r}\text { Fringe } \\
\text { Benefits }\end{array}$ & $\begin{array}{r}\text { Rented } \\
\text { Equipment }\end{array}$ & $\begin{array}{r}\text { Materials/ } \\
\text { Services }\end{array}$ & Totall \\
\hline \multicolumn{6}{|l|}{ LANDFILLOPERATIONS } \\
\hline Sanitary Landfill Operation & 654 & 229 & & 8,245 & 9,127 \\
\hline Methane Gas Collection & 0 & & & 4,436 & 4,436 \\
\hline Lendfill Expansion & 0 & & & 38,832 & 38,832 \\
\hline Suspect Water Break (1/26/93) & 224 & & & 47 & 271 \\
\hline New Monitoring Wells & 0 & & & 313 & 313 \\
\hline General Maintenance (West Springfield) & 0 & & & 514 & 514 \\
\hline Storm Water Drain Project (West Springfield & 11,441 & 4,004 & 5,725 & 6,040 & 27,210 \\
\hline Subtotal & 12,319 & 4,233 & 5,725 & 58,427 & 80,704 \\
\hline \multicolumn{6}{|l|}{ SALE OF MATERIALS \& SERVICES } \\
\hline Taste of Springfield $(6 / 17 / 92$ to $6 / 22 / 92)$ & 0 & & & & 0 \\
\hline Glendi Festival & 128 & & & . & 128 \\
\hline Pancake Breakfast (5/15 \& 5/16/93) & 1,235 & & & & 1,235 \\
\hline Eastern Ave \& Olive Street & 809 & 238 & 1,960 & 6,271 & 9.278 \\
\hline Worthington Fort Clean Up & 395 & 138 & & 161 & 694 \\
\hline Taste of Springfield 6/16/93 & 7,474 & 230 & & & 7,704 \\
\hline Subtotal & 10,041 & 607 & 1,960 & 6,432 & 19,040 \\
\hline TOTAL COSTS FY93 & $1,934,856$ & 498,903 & 10,665 & 378,915 & $2,823,338$ \\
\hline
\end{tabular}

SOURCE: DPW, "Job Cost Summary Report," Computer Printout, August 12, 1993. 
Table C.4: Vohiclo and Equipment O\&M and Capital Cost Data

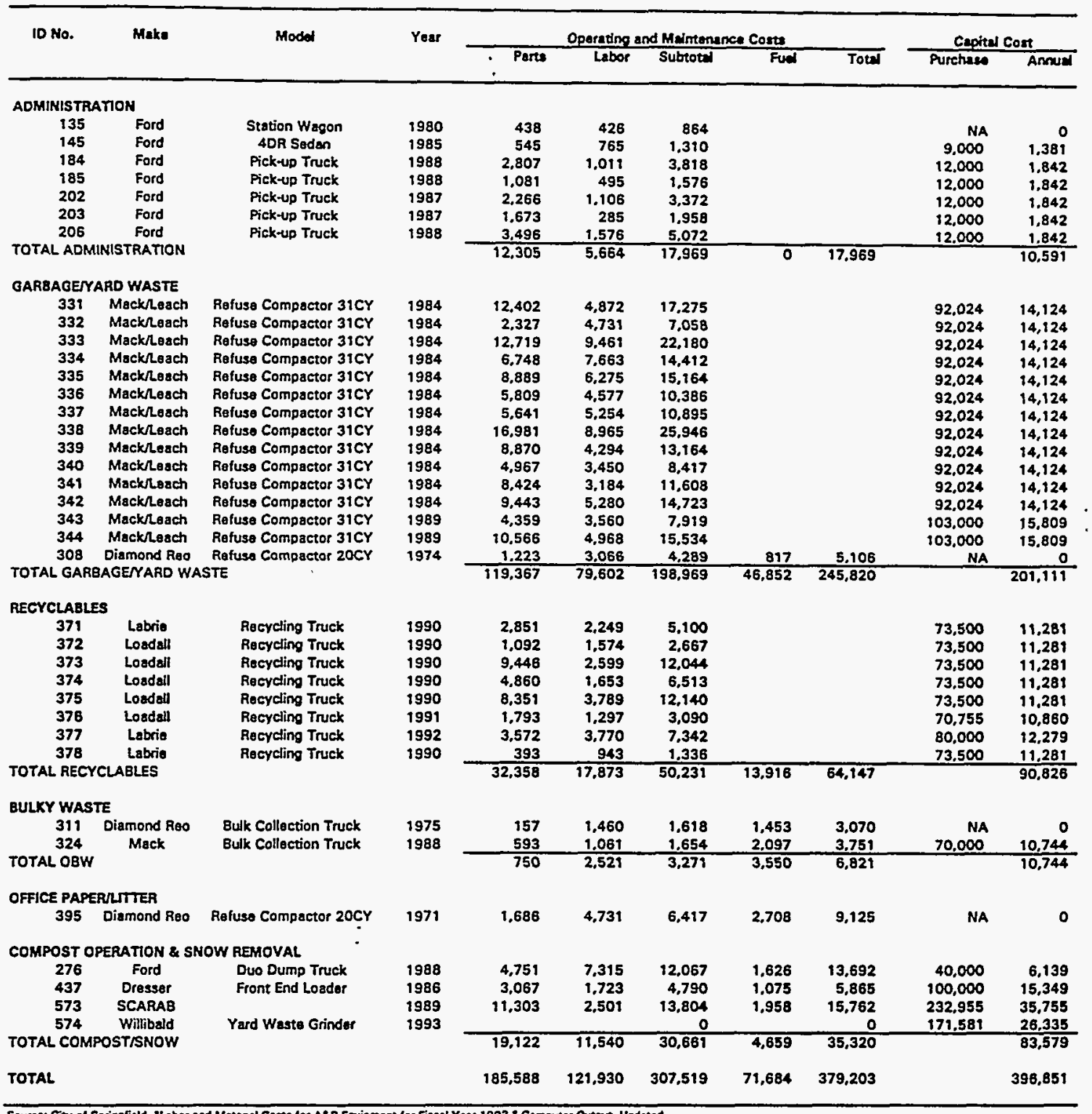

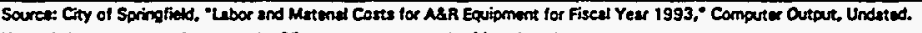

Note: Lebor costs were increased by 35 percenk to sccourk lox fringe benelits. 
Table C.5: Monthly Paymants to Landfill Contractor in FY 1993

\begin{tabular}{|c|c|c|c|c|c|c|c|c|c|c|c|c|c|}
\hline Charge & Total & Jul & Aug & Sep & Oct & Nov & Dec & $\operatorname{san}$ & Fob & Mar & Apr & May & Jun \\
\hline Base Operating Feo & $\$ 273,000$ & $\$ 22,750$ & $\$ 22,750$ & $\$ 22,750$ & $\$ 22,750$ & $\$ 22,750$ & $\$ 22,750$ & $\$ 22,750$ & $\$ 22,750$ & $\$ 22,750$ & $\$ 22,750$ & $\$ 22,750$ & $\$ 22,760$ \\
\hline $\begin{array}{l}\text { Environmental Monitoring, otc. } \\
\text { Deduction per Bid Item A-1 }\end{array}$ & $\begin{array}{c}89,250 \\
(71,663)\end{array}$ & 7,438 & 7,438 & 7,438 & $\begin{array}{c}7,438 \\
(7,963)\end{array}$ & $\begin{array}{c}7,438 \\
(7,963)\end{array}$ & $\begin{array}{c}7,438 \\
(7,963)\end{array}$ & $\begin{array}{l}7,438 \\
(7,963)\end{array}$ & $\begin{array}{c}7,438 \\
(7,963)\end{array}$ & $\begin{array}{c}7,438 \\
(7,963)\end{array}$ & $\begin{array}{c}7,438 \\
(7,963)\end{array}$ & $\begin{array}{l}7,438 \\
(7,963)\end{array}$ & $\begin{array}{r}7,438 \\
(7,963)\end{array}$ \\
\hline WTE Facility Ash & 288,998 & 24,931 & 27,604 & 23,203 & 25,615 & 22,616 & 24,707 & 20,016 & 16,590 & 29,683 & 29,245 & 22,231 & 22,558 \\
\hline WTE Facility Bypass & 0 & $\mathbf{0}$ & 0 & 0 & 0 & 0 & 0 & 0 & 0 & 0 & 0 & 0 & 0 \\
\hline WWTP Sludge & 178 & 0 & 0 & 0 & 0 & 178 & 0 & 0 & 0 & 0 & 0 & 0 & 0 \\
\hline WWTP Sludge - Compost & 125,259 & 11,301 & 5,325 & 9,319 & 11,034 & 8,708 & 10,835 & 11,300 & 12,359 & 13,690 & 13,454 & 11,040 & 6,892 \\
\hline WWTP Grit \& Screenings & 17,626 & 960 & 1.441 & 1,105 & 609 & 1,051 & 1.379 & 1.222 & 1,044 & 3,076 & 2,329 & 1,377 & 1,944 \\
\hline Street Sweepings & 32,884 & 3,811 & 4,293 & 4,244 & 170 & 135 & 0 & 530 & 0 & 0 & 7,029 & 5,783 & 6,889 \\
\hline Catch Basin/Sewer Cleanings & 17,485 & 2,350 & 2,993 & 1,441 & 1,691 & 1,230 & 436 & 514 & 399 & 533 & 2,036 & 1,520 & 2,339 \\
\hline Other & 10,640 & & & & & & & & 10,640 & & & & \\
\hline Total & $\$ 783,558$ & $\$ 73,532$ & $\$ 71,844$ & $\$ 69,499$ & $\$ 61,344$ & $\$ 56,143$ & $\$ 59,582$ & $\$ 55,808$ & $\$ 63,258$ & $\$ 69,207$ & $\$ 76,318$ & $\$ 64,176$ & $\$ 62,847$ \\
\hline
\end{tabular}

w

Source: Resourco Control, Inc., Invoicos from July 1992 through June 1993. 
Table C.6: Resource Control, Inc. Invoices - Tonnages

\begin{tabular}{|c|c|c|c|c|c|c|c|c|c|c|c|c|c|}
\hline Charge & Total ${ }^{\circ}$ & Jul & Aug & Sep & Oct & Nov & Dec & Jan & Feb & Mar & Apr & May & Jun \\
\hline $\begin{array}{l}\text { WTE Facility Ash (dry) } \\
\text { WTE Facility Ash (wot) }\end{array}$ & $\begin{array}{l}22,057 \\
38,375\end{array}$ & $\begin{array}{l}1,978 \\
3,463\end{array}$ & $\begin{array}{l}2,110 \\
3,696\end{array}$ & $\begin{array}{l}1,687 \\
2,954\end{array}$ & $\begin{array}{l}1,958 \\
3,430\end{array}$ & $\begin{array}{l}1,729 \\
3,028\end{array}$ & $\begin{array}{l}1,827 \\
3,167\end{array}$ & $\begin{array}{l}1,618 \\
2,805\end{array}$ & $\begin{array}{l}1.268 \\
2,198\end{array}$ & $\begin{array}{l}2,221 \\
3,842\end{array}$ & $\begin{array}{l}2,236 \\
3,868\end{array}$ & $\begin{array}{l}1,700 \\
2,940\end{array}$ & $\begin{array}{l}1,725 \\
2,984\end{array}$ \\
\hline WTE Facility Bypass & 0 & 0 & 0 & 0 & 0 & 0 & 0 & 0 & 0 & 0 & 0 & $\begin{array}{r}2,940 \\
0\end{array}$ & $\begin{array}{r}2,984 \\
0\end{array}$ \\
\hline WWTP Sludge (dry) & 14 & 0 & 0 & 0 & 0 & 14 & 0 & 0 & 0 & 0 & 0 & 0 & 0 \\
\hline WWTP Sludgo - Compost & 9,576 & 864 & 407 & 712 & 844 & 666 & 828 & 864 & 945 & 1,047 & 1,029 & 844 & 527 \\
\hline WWTP Grit \& Screenings & 1,340 & 73 & 110 & 84 & 47 & 80 & 105 & 93 & 80 & 235 & 178 & 105 & 149 \\
\hline Street Sweepings & 2,514 & 291 & 328 & 324 & 13 & 10 & 0 & 41 & 0 & 0 & 537 & 442 & 527 \\
\hline Catch Basin/Sewer Cleanings & 1,337 & 180 & 229 & 110 & 129 & 94 & 33 & 39 & 31 & 41 & 156 & 116 & 179 \\
\hline Other & 813 & & & & & & & & 813 & & & & \\
\hline Total & 53,970 & 4,871 & 4,770 & 4,186 & 4,462 & 3,892 & 4,134 & 3,842 & 4,067 & 5,164 & 5,768 & 4.448 & 4,365 \\
\hline
\end{tabular}

Source: Resourco Control, Inc., Invoices Irom July 1992 through June 1993. 
Table C.7: Waste to Energy Service Fee Calculation - FY 1993

\begin{tabular}{lcrr}
\hline Variable & Monthly & Annual & $\begin{array}{r}\text { Annual } \\
\text { Modified }\end{array}$ \\
\hline O\&M CHARGE & 136,758 & $1,641,096$ & $1,641,096$ \\
CAPITAL CHARGE & 149,201 & $1,790,412$ & $1,790,412$ \\
PASSTHROUGH COSTS & 133,724 & $1,604,688$ & $1,129,718$ \\
SUBTOTAL & 419,683 & $5,036,196$ & $4,561,226$ \\
\cline { 2 - 4 } & $(203,140)$ & $(2,437,680)$ & $(2,437,680)$ \\
ENERGY REVENUES & 216,543 & $2,598,516$ & $2,123,546$ \\
\hline
\end{tabular}




\section{ity DEP's Monthly Operating Statement, FY 1993}

\begin{tabular}{|c|c|c|c|c|c|c|c|c|c|c|c|c|c|}
\hline \begin{tabular}{|l} 
KEY DATA \\
Period Net Revenue (a)
\end{tabular} & $\frac{J u !}{\$ 7,363}$ & $\frac{\text { Aug }}{\$ 37.145}$ & $\frac{\text { Sop }}{\$ 32.699}$ & $\frac{\text { Oct }}{535.363}$ & Nov & Dec & $\frac{\operatorname{Jan}}{562.39}$ & Feb & Mar & Apr & Mav & Jun & Total \\
\hline Gross Incoming Tons & 3,656 & 3,349 & $\frac{802,005}{3,643}$ & $\frac{\$ 0,503}{3,629}$ & $\frac{\$ 43,646}{3.528}$ & $\frac{568,464}{4,393}$ & $\frac{\$ 63,139}{3709}$ & $\$ 55,765$ & $\$ 78,443$ & $\$ 99,945$ & $\$ 84,150$ & $\$ 69,326$ & $\$ 665,447$ \\
\hline Non-designated Tons & 72 & 61 & 103 & 45 & 172 & 698 & $\frac{3,709}{515}$ & $\frac{2,843}{82}$ & $\frac{3,570}{53}$ & 3,959 & 3,857 & 3,925 & 44,060 \\
\hline Designated Tons & 3,584 & 3,288 & 3,540 & 3,584 & 3,355 & 3,695 & 3,193 & $\begin{array}{r}02 \\
2,761\end{array}$ & $\begin{array}{r}53 \\
3.517\end{array}$ & 72 & 382 & 120 & 2,376 \\
\hline Tons Sold & 3,971 & 3,316 & 3,591 & 3,696 & 3,241 & 3,943 & 3,871 & 2,751 & $\frac{3,617}{3,391}$ & 3,887 & 3,475 & 3,804 & 41,683 \\
\hline
\end{tabular}

\begin{tabular}{|c|c|c|c|c|c|c|c|c|c|c|c|c|c|}
\hline REVENUE ALLOCATION & Jul & Aug & Sep & Oct & Nov & Dec & Jan & Fob & Mar & Apr & May & Jun & Total \\
\hline Wieghted Avg. Revenue/ton & $\$ 2.01$ & $\$ 11.09$ & $\$ 8.98$ & $\$ 9.74$ & $\$ 12.37$ & $\$ 13.31$ & $\$ 17.02$ & $\$ 19.61$ & $\$ 21.97$ & $\$ 25.25$ & $\$ 21.82$ & $\$ 17.66$ & \\
\hline$\frac{\text { Less } \$ 29.28 / \text { ton }}{\text { Times Designated Tons }}$ & $(27.27)$ & $(18.19)$ & $(20.30)$ & (19.54) & $(16.91)$ & (15.97) & $(12.26)$ & (9.67) & (7.31) & (4.03) & $(7.46)$ & $(11.62)$ & \\
\hline $\begin{array}{l}\text { Times Designated Tons } \\
\text { Time 0.65 DEP Share }\end{array}$ & $(97,713)$ & $(59,799)$ & $(71,864)$ & $(70,027)$ & $(56,728)$ & $(59,017)$ & $(39,138)$ & $(26,689)$ & $(25,695)$ & $(15,679)$ & $(25,929)$ & $(44,194)$ & $\frac{1592,47}{1205.10}$ \\
\hline ARIABLE FEE & $100,0(4)$ & $(38,870)$ & $(46,771)$ & $(45,518)$ & $(36,873)$ & $(38,361)$ & $(25,440)$ & $(17,348)$ & $(16,702)$ & $(10,192)$ & $(16,854)$ & $(28,726)$ & 1385,10 \\
\hline
\end{tabular}

VARIABIE FEE

Tip Fee X

\begin{tabular}{l} 
FIXED FEE \\
\hline$\$ 39,888$ per month
\end{tabular}

DEP DIRECT PAYMENTS

$\dot{\omega}$

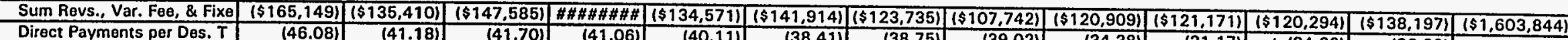
DEP INDIRECT PAYMENTS

\begin{tabular}{|c|c|c|c|c|c|c|c|c|c|c|c|c|}
\hline $\begin{array}{l}\text { General \& Administrative (c) } \\
\text { Real Estate (d) }\end{array}$ & $\frac{(\$ 8,333)}{(49,436)}$ & $\frac{(\$ 8,333)}{(49,436)}$ & $\frac{(\$ 8,333)}{(49,436)}$ & $\frac{(\$ 8,333)}{(49,436)}$ & $\frac{(\$ 8,333)}{(49,436)}$ & $\frac{(\$ 8,333)}{(199361}$ & $(58,333)$ & $(\$ 8,333)$ & $1 \$ 8,333$ & $(\$ 8,33$ & $1 \$ 8,333$ & $(\$ 8,333)$ \\
\hline
\end{tabular}

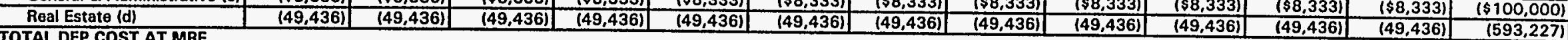
TOTAL DEP COST AT MRF

Total Payments

Payment per Des. Ton

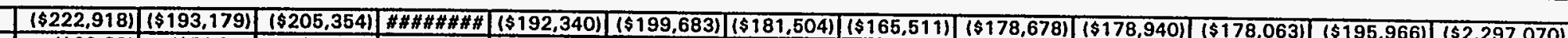

Payment per Total Ton

\begin{tabular}{|r|r|r|r|r|r|r|r|}
\hline$(\$ 62.20)$ & $(\$ 58.75)$ & $(\$ 58.02)$ & $(\$ 67.17)$ & $(\$ 57.33)$ & $(\$ 54.04)$ & $(\$ 56.84)$ & $(\$ 59.94)$ \\
\hline
\end{tabular}

\begin{tabular}{r|r|}
$(\$ 178,678)$ \\
$(\$ 50.81)$
\end{tabular}

\begin{tabular}{|r|r|r|r|}
\hline 178,940$)$ & $(\$ 178,063)$ & $(\$ 195,966)$ & $(\$ 2,297,070)$ \\
\hline$(\$ 46.04)$ & $(\$ 51.25)$ & $(\$ 51.51)$ & $(\$ 55.11)$ \\
\hline
\end{tabular}

(a) Revenues are net of Special Mixed Paper (which is included in tonnage but not in price, per deal with RAS)

(b) Variable fee of $\$ 17.23 /$ designated ton in CY92 and $\$ 18.29 /$ ton in CY93 applies to first 42,500 annual designated tons; rate is $\$ 1.00 /$ designated ton thereafter.

(c) Assumed to be $\$ 100,000$ per year.

(d) $\$ 5.5$ million amortized over 15 years at $7 \%$ annual interest.

Sources:

1. DEP, "Monthly Revenue, Springfield Material Recycling Facility," December 1992, written by Charles Leto, Department of Solid Waste Management.

2. DEP, "Monthly Revenue \& Fiscal Year 94, Springfield Material Recycling Facility," January 27, 1993, written by Greg Cooper, Department of Solid Waste Management. 
Table C.9: Department of Public Works FY 1993 Job Cost Expenses and Labor Hours

\begin{tabular}{|c|c|c|c|c|c|}
\hline \multirow[t]{2}{*}{ Division } & \multirow[t]{2}{*}{ Cost } & \multicolumn{4}{|c|}{ Hours } \\
\hline & & Regular & Overtime & Equipment & Total \\
\hline Administration & $\$ 633,210$ & $32,627.0$ & & . & $32,627,0$ \\
\hline Community Development & 43,886 & $2,105.0$ & 13.0 & & $2,118.0$ \\
\hline Contractual Services & 101,916 & & & & 0.0 \\
\hline Engineering & 587,284 & $30,002.5$ & 221.0 & $1,532.5$ & $31,756.0$ \\
\hline Federal \& State Grants & $5,715,148$ & $24,304.9$ & $2,323.5$ & $5,142.0$ & 31.770 .4 \\
\hline Highways \& Bridges & 924,364 & $71,748.9$ & $1,582.5$ & & $73,331.4$ \\
\hline Housing Authority & 15,407 & & $1,044.0$ & & $1,044.0$ \\
\hline Industrial Pretreatment & 413,933 & $16,057.5$ & $1,134.5$ & & $17,192.0$ \\
\hline Landfill Expansion & $3,585,900$ & 309 & 106 & 96 & 510.5 \\
\hline Local Wastewater (Sewers) & $7,381,634$ & $61,491.5$ & $3,213.5$ & 4.0 & $64,709.0$ \\
\hline Meters/Permits & 311,097 & $18,028.5$ & 540.5 & 645.0 & $19,214.0$ \\
\hline Park Department & 80,976 & $5,421.0$ & 8.5 & & $5,429.5$ \\
\hline Parking Authority & 112,394 & 807.0 & 201.5 & 893.0 & $1,901.5$ \\
\hline Pavement Management & 156,698 & 595.0 & & & 595.0 \\
\hline Resurfacing of Private Ways & 95,929 & $2,725.0$ & 7.5 & & $2,732.5$ \\
\hline Schoois & 6,558 & & & & 0.0 \\
\hline Signalization & 52,654 & 989.5 & 5.0 & & 994.5 \\
\hline Snow \& lce Control & $1,113,868$ & $17,494.5$ & $11,101.0$ & 8.0 & $28,603.5$ \\
\hline Solid Waste & $5,007,133$ & 147.233 .0 & $13,546.7$ & & $160,779.7$ \\
\hline Stormwater & 250,985 & $19,464.3$ & 212.0 & & $19,676.3$ \\
\hline Street Lighting & $2,159,729$ & & & & 0.0 \\
\hline Traffic & 572,607 & $25,579.7$ & 353.0 & $4,186.0$ & $30,118.7$ \\
\hline Waste Water Treatment Plant & $11,719,068$ & $157,186.6$ & $10,294.9$ & & $167,481.5$ \\
\hline Workmans Compensation & 116,756 & & & & 0.0 \\
\hline Yards, Garage, Stores & $1,825,661$ & $67,664.0$ & 395.0 & - & $68,059.0$ \\
\hline Bond Funds & $11,707,488$ & $51,894.1$ & $1,935.0$ & $2,694.0$ & $56,523.1$ \\
\hline Interest (WWTP) & $1,061,345$ & & & & 0.0 \\
\hline Other & 10,330 & 300.0 & & & 300.0 \\
\hline Total & $55,763,958$ & 754,028 & 48,239 & 15,201 & $817,467.1$ \\
\hline
\end{tabular}

Source: DPW, "Job Cost Summary Report." Computer Printout, August 12, 1993. 
Table C.10: City General \& Administrative Costs (FY 1993)

\begin{tabular}{|c|c|c|c|c|c|}
\hline $\begin{array}{l}\text { City Department } \\
\text { or.Office } \\
\text { OFFICE }\end{array}$ & $\begin{array}{c}\text { Expenditures }^{\text {Acutal }} \\
\text {. }\end{array}$ & $\begin{array}{l}\text { Prior Year } \\
\text { Expenses }\end{array}$ & $\begin{array}{r}\text { Encumbered } \\
\text { Funds }\end{array}$ & $\begin{array}{l}\text { Direct } \\
\text { Labor } \\
\text { Costs }\end{array}$ & $\begin{array}{r}\text { Adjusted } \\
\text { City G\&A } \\
\text { Costs }\end{array}$ \\
\hline City Auditor & 571,664 & 76,676 & 64,567 & 466,021 & 794,900 \\
\hline City Clerk & 569,944 & 9,298 & 6,254 & 502,619 & 742,800 \\
\hline City Collector & 442,486 & 0 & 1,409 & 315,592 & 554,400 \\
\hline City Council & 99,311 & 0 & 0 & 90,501 & 131,000 \\
\hline City Treasurer & $1,427,695$ & 35,989 & 3,560 & 276,269 & $1,492,000$ \\
\hline Data Processing & $1,040,739$ & 34,648 & 27,706 & 388,076 & $1,169,600$ \\
\hline Finance Department & 252,959 & 1,236 & 1,236 & 237,038 & 335,900 \\
\hline Labor Relations & 198,622 & 0 & 2,621 & 188,095 & 267,100 \\
\hline Law Department & 583,454 & 31.859 & 40,344 & 474,329 & 758,000 \\
\hline Mayor's Office & 473,859 & 50,461 & 3,989 & 269,873 & 521,800 \\
\hline Personnel Department & $2,521,620$ & 350,486 & 16,235 & 666,032 & $2,420,500$ \\
\hline Public Building Administration & 283,300 & 0 & 3,352 & 256,472 & 376,400 \\
\hline Public Building Maintenance & $1,931,148$ & 0 & 22,369 & $1,488,940$ & $2,474,600$ \\
\hline Public Building Operation & 901,094 & 0 & 28,307 & 303,457 & $1,035,600$ \\
\hline Purchase Department & 651,886 & 9,692 & 9,956 & 580,787 & 855,400 \\
\hline TOTAL INDIRECT & $11,949,781$ & 600,346 & 231,905 & $6,504,099$ & $13,930,000$ \\
\hline
\end{tabular}

Source: City of Springfield, "Year End Report," Computer Printout, August 4, 1993.

NOTES:

(1) Adjusted cost is equal to the product of 1.10 times (Actual Expenditure minus Ptior Year Expenses plus Encumerences plus $\mathbf{3 5}$ times Direct Labor Costs).

(2) Figures do not contain any Capital Outlays.

(1) Adjusted costs are rounded to the nearest $\$ 100$. 


\section{Appendix D - Captial Cost Calculation}

A capital expense is the purchase of an asset or service with a useful life of greater than one year. Accountants report capital expenses as either capital outlays, i.e., the actual payment made during the year, or depreciated/amortized expenses, e.g., using straight-line depreciation the capital outlay is divided by the useful life of the asset.

Capital assets may be purchased entirely with cash, financed over time using borrowed funds, or utilize a combination of the two. If totally or partially financed, interest payments on borrowed funds are reported by accountants as interest expenses.

Following these accounting practices, the cost of a capital asset in a given reporting period (e.g., fiscal year) is reported as either the capital outlay incurred, or the depreciation/amortization expense incurred in the reporting period, plus interest paid, if any, on borrowed funds to finance the capital asset. Some financial reports, such as a cash flow analysis, also report the actual debt service, i.e., principal plus interest payments, on borrowed funds.

Although these approaches are appropriate for generating financial statements of non-profit organizations, none is an appropriate measure of the economic capital costs of the asset. The reporting of capital outlays does not recognize that a capital asset will be used over two or more years and that, therefore, its costs should be spread over the asset's useful life. The depreciation/amortization approach does not adequately distinguish between the same asset purchased with cash or with borrowed funds. Because loan repayment and debt service payments, and in particular the interest portion of such payments, can vary significantly from year to year based solely on the means of borrowing funds and not the use of the asset, these expenses are not an appropriate measure of the capital cost of the asset.

The approach used in the report to calculate capital costs is to "annualize" or "capitalize" capital outlays over the useful life of the asset using a cost of capital of 7 percent. ${ }^{136}$ Generally, the cost of capital reflects the rate of return expected on invested funds.

Using this approach the capital cost of an asset is independent of the method used to pay for the asset, and has the same annual value over the useful life of the asset.

To illustrate the method used to calculate capital costs and compare it to the other ways of reporting capital expenses, consider a transfer tractor and trailer with a 5 year useful life and a . purchase price of $\$ 105,000$.

To estimate the annual capital cost the purchase price, i.e., capital outlay, of $\$ 105,000$ is

${ }^{136}$ The cost of capital is related to the rates of return that can be earned on invested funds and the rates of interest that must be paid on borrowed funds. As the economy changes and interest rates increase or decrease, the cost of capital may also change over time. The 7-percent cost of capital is about the mid-point of cost of capital often used for public entities. 
Table D.1: Capitalization Factors

\begin{tabular}{cllllll}
\hline \multirow{2}{*}{$\begin{array}{l}\text { Number } \\
\text { of Years }\end{array}$} & \multicolumn{7}{c}{ Cost of Capital } \\
\cline { 2 - 7 } & $\mathbf{5 \%}$ & $\mathbf{6 \%}$ & $\mathbf{7 \%}$ & $\mathbf{8 \%}$ & $\mathbf{9 \%}$ & $\mathbf{1 0 \%}$ \\
\hline & 0.5378 & 0.5454 & 0.5531 & 0.5608 & 0.5685 & .0 .5762 \\
2 & 0.3672 & 0.3741 & 0.3811 & 0.3880 & 0.3951 & 0.4021 \\
3 & 0.2820 & 0.2886 & 0.2952 & 0.3019 & 0.3087 & 0.3155 \\
4 & 0.2310 & 0.2374 & 0.2439 & 0.2505 & 0.2571 & 0.2638 \\
5 & 0.1295 & 0.1359 & 0.1424 & 0.1490 & 0.1558 & 0.1627 \\
10 & 0.0963 & 0.1030 & 0.1098 & 0.1168 & 0.1241 & 0.1315 \\
15 & 0.0802 & 0.0872 & 0.0944 & 0.1019 & 0.1095 & 0.1175 \\
20 & 0.0651 & 0.0726 & 0.0806 & 0.0888 & 0.0973 & 0.1061 \\
30 & 0.0583 & 0.0665 & 0.0750 & 0.0839 & 0.0930 & 0.1023 \\
40 & 0.0548 & 0.0634 & 0.0725 & 0.0817 & 0.0912 & 0.1009 \\
50 & & & & & & \\
\hline
\end{tabular}


Table D.2: Comparison of Capital Costs and Other Accounting Methods - Purchase of Tractor/Trailer with 5-Year Useful Life for $\$ 105,000$

\begin{tabular}{|c|c|c|c|c|c|c|c|c|c|}
\hline Year & $\begin{array}{r}\text { Capital } \\
\text { Cost (\$) } \\
\end{array}$ & Case 1 & Case 2 & Case 3 & Case 4 & Case 5 & Case 6 & Case 7 & $\overline{\text { Case } 8}$ \\
\hline $\begin{array}{l}1 \\
2 \\
3 \\
4 \\
5\end{array}$ & $\begin{array}{l}25,609 \\
25,609 \\
25,609 \\
25,609 \\
25,609\end{array}$ & $\begin{array}{r}105,000 \\
0 \\
0 \\
0 \\
0 \\
\end{array}$ & $\begin{array}{r}112,350 \\
6,072 \\
4,704 \\
3,241 \\
1,675 \\
\end{array}$ & $\begin{array}{r}112,350 \\
5,880 \\
4,410 \\
2,940 \\
1,470 \\
\end{array}$ & $\begin{array}{l}21,000 \\
21,000 \\
21,000 \\
21,000 \\
21,000\end{array}$ & $\begin{array}{l}28,350 \\
27,072 \\
25,704 \\
24,241 \\
22,675\end{array}$ & $\begin{array}{l}28,350 \\
26,880 \\
25,410 \\
23,940 \\
22,470 \\
\end{array}$ & $\begin{array}{l}25,609 \\
25,609 \\
25,609 \\
25,609 \\
25,609 \\
\end{array}$ & $\begin{array}{l}28,350 \\
26,880 \\
25,410 \\
23,940 \\
22,470 \\
\end{array}$ \\
\hline
\end{tabular}

Definition of Cases:

Case 1: Capital Outlay reporting. Purchased with cash.

Case 2: Capital Outlay reporting. Financed with borrowed funds. Interest rate of $7 \%$. Constant annual payments.

Case 3: Capital Outlay reporting. Financed with borrowed funds. Interest rate of $7 \%$. Constant prinicipal payment, interest paid on unpaid balance.

Case 4: Straight-line depreciation/amortization reporting. Purchased with cash.

Case 5: Straight-line depreciation/amortization reporting. Financed with borrowed funds. Interest rate of $7 \%$. Constant annual payments.

Case 6: Straight-line depreciation/amortization reporting. Financed with borrowed funds. Interest rate of $7 \%$. Constant principal payments.

Case 7: Debt Service reporting. Financed with borrowed funds. Interest rate of 7\%. Constant annual payments.

Case 8: Debt Service reporting. Financed with borrowed funds. Interest rate of $7 \%$. Constant annual principal payments. 
Public reporting burden for this collection of information is estimated to average 1 hour per response, including the time for reviewing instructions, searching existing data sources, gathering and maintaining the data needed, and completing and reviewing the collection of information. Send comments regarding this burden estimate or any other aspect of this collection of information, including suggestions for reducing this burden to Washington Headquarters Services, Directorate for Information Operations and Reports, 1215 Jefferson Davis Highway, Suite 1204, Arlington, VA 22202-4302, and to the Office of Management and Budget, Paperwork Reduction Project (07040188), Washington, DC 20503.
1. AGENCY USE ONLY (Leave
2. REPORT DATE
3. REPORT TYPE AND DATES COVERED blank)

September 1995
Final Subcontract Report
4. TITLE AND SUBTITLE

Integrated Solid Waste Management of Springield, Massachusetts
5. FUNDING NUMBERS

(C) AAL-3-13185-01

(TA) WMS1.1010

6. AUTHOR(S)

7. PERFORMING ORGANIZATION NAME(S) AND ADDRESS(ES)

The Solid Waste Association of North America

8. PERFORMING

ORGANIZATION

REPORT NUMBER

DE95009247

9. SPONSORINGMONITORING AGENCY NAME(S) AND ADDRESS(ES)

10.

SPONSORNGMONITORING

National Renewable Energy Laboratory

1617 Cole Boulevard

AGENCY REPORT

NUMBER

Golden, CO 80401-3393

NREL/TP-430-8137

\section{SUPPLEMENTARY NOTES}

12a. DISTRIBUTION/AVAILABLITY STATEMENT

National Technical Information Service

U.S. Department of Commerce

5285 Port Royal Road

Springfield, VA 22161 12b. DISTRIBUTION CODE

UC-1414

\section{ABSTRACT (Maximum 200 words)}

One of a series of six reports that describes in detail the solid waste management of Springfield, Massachusetts; the energy consumed to operate the system, and the environmental performance requirements for each of the system's waste-processing and disposal facilities. The report is in two parts, a condensed version and an in-depth report with added detail.

\begin{tabular}{|l|l} 
14. SUBJECT TERMS & 15. NUMBER OF PAGES
\end{tabular}

Municipal solid waste management; energy consumption; Scottsdale, Arizona; cost analysis; recycling, waste-to-energy.

\begin{tabular}{|l|l|l|l|}
\hline $\begin{array}{l}\text { 17. SECURTY } \\
\text { CLASSFICATION } \\
\text { OF REPORT } \\
\text { Unclassified }\end{array}$ & $\begin{array}{l}\text { 18. SECURTY } \\
\text { CLASSIFICATION } \\
\text { OF THIS PAGE }\end{array}$ & $\begin{array}{l}\text { 19. SECURITY } \\
\text { CLASSIFICATION } \\
\text { OF ABSTRACT }\end{array}$ & $\begin{array}{l}\text { 20. LIMTTATION OF } \\
\text { ABSTRACT }\end{array}$ \\
\hline & & & \\
\hline & & & \\
\hline
\end{tabular}

